\title{
П1равова Позиція
}

(правонаступник наукового журналу

“Вісник Академії митної служби України.

Серія: "Право")

\section{№ 4 (29)}

Включено до Переліку наукових фахових видань України, у яких можуть публікуватися результати дисертаційних робіт з юридичних наук (Наказ Міністерства освіти і науки Украйни від 17.03.2020 р. № 409, додаток 1)

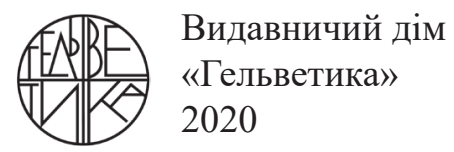




\author{
Правова позиція \\ (правонаступник наукового журналу “Вісник Академії митної служби України. \\ Серія: "Право") \\ Науковий журнал \\ Видається чотири рази на рік \\ Рекомендовано до друку та до поширення через мережу Інтернет вченою радою \\ Університету митної справи та фінансів (протокол № 8 від 25.12.2020) \\ Статті у виданні перевірені на наявність плагіату за допомогою програмного забезпечення \\ StrikePlagiarism.com від польської компанії Plagiat.pl. \\ «Правова позиція» включено до міжнародної наукометричної бази \\ Index Copernicus International (Республіка Польща)
}

\section{Редакційна колегія:}

Приймаченко Д. В. - Д.ю.н., проф.

(головний редактор);

Мінка Т. П. - д.ю.н., доц.

(заступник головного редактора);

Варава В. В. - к.ю.Н., доц.;

Гармаш С. В. - к.ю.н., доц.;

Гелерт Лотар - д.ю.н., проф., Німецький урядовий

університет державного управління

(Федеративна Республіка Німеччина);

Гречанюк С. К. - д.ю.Н., проф.;

Додін Є. В. - д.ю.н., проф.,

заслужений діяч науки і техніки України;

Кашубський Михаіл - д.ю.н., доц.,

Університет Чарльза Стерта, голова Секретаріату

Міжнародної мережі митних університетів (Австралія);

Книш С. В. - к.ю.Н., доц.;
Легеза С. О. - д.ю.н., проф.;

Ліпинський В. В. - к.ю.Н., доц.;

Лютіков П. С. - Д.ю.н., доц.;

Макаренко А. В. - к.ю.н.;

Миронюк Р. В. - Д.ю.н., проф.;

Перепьолкін С. М. - к.ю.н., доц.;

Раковський Мачей - доктор габ., доц.,

Лодзький університет (Республіка Польща);

Сабо Андреа - доктор наук, проф.,

Університет публічної служби (Угорська Республіка);

Сироїд Т. Л. - д.ю.н., проф.;

Тертишник В. М. - Д.ю.н., проф.;

Тильчик В. В. - к.ю.н., доц.;

Чижович Всслав - доктор наук у галузі митної політики та митного права, проф., Головна торгова школа у Варшаві (Республіка Польща);

Щербина В. І. - д.ю.н., проф.

ISSN 2521-6473

\author{
Коректори: Н. В. Пірог, Н. С. Ігнатова \\ Комп'ютерна верстка: Ю. В. Ковальчук \\ Свідоцтво про державну реєстрацію: серія КВ № 21947-11847ПР від 31.12.2015 р. \\ Адреса: м. Дніпро, вул. Володимира Вернадського, 2/4, 49000 \\ Тел.: +38 (099) 7296379 \\ E-mail: editor@legalposition.umsf.in.ua \\ Видавництво і друкарня - Видавничий дім «Гельветика» \\ 65101, Україна, м. Одеса, вул. Інглезі, 6/1 \\ Телефони: +38 (095) $9344828,+38$ (097) 7230608 \\ E-mail:mailbox@helvetica.com.ua \\ Свідоцтво суб'єкта видавничої справи \\ ДК № 6424 від 04.10.2018 p. \\ Підписано до друку 28.12.2020. Формат 60×84/8. Папір офсетний. \\ Гарнітура Таймс. Ум. друк. арк. 12,32. Обл.-вид. арк. 13,02. \\ Наклад 300 прим. Замовлення № 0121/20.
}




\section{ICTOРІЯ ТА ТЕОРІЯ ПРАВА}

С. С. Дурнов. Правове становище адвокатури в 1919-1939 роках на етнічних землях України у складі Польщі та Чехословаччини 6

В. Р. Нестор. Зародження міського самоврядування у Сполученому Королівстві.

\section{АДМІНІСТРАТИВНЕ ТА МИТНЕ ПРАВО}

Ю. В. Борисова. Провадження у справах про адміністративні правопорушення, що пов'язані $з$ корупцією: загальнотеоретичний аспект.

С. В. Кононенко. Об’єкт адміністрування податків у сфері обігу підакцизних товарів

Є. О. Легеза. Особливості здійснення контролю під час надання публічних послуг задля запобігання корупційним ризикам

Р. В. Мазурик. Реалізація Антикорупційної стратегії на 2020-2024 роки в діяльності органів прокуратури

О. П. Махмурова-Дишлюк. Права і свободи людини та громадянина

в умовах збройного конфлікту в Україні як об'єкт адміністративно-правового забезпечення .34

Є. А. Кобрусєва. Судовий розгляд справ у провадженнях щодо мирних зібрань

Н. Ф. Скляр. Принципи фінансової відповідальності за порушення податкового законодавства .....

А. В. Тарасюк. Теоретико-правове підгрунтя інформаційної етики в системі забезпечення кібербезпеки ....

T. І. Шинкар. Судовий захист права на доступ до публічної інформації. 53

\section{ЦИВІЛЬНЕ ПРАВО}

О. О. Біляєв. Особливості відповідальності у сфері спорту .58

С. В. Завальнюк. Проблематика співвідношення поняття прогалини в цивільному законодавстві та деяких схожих правових понять і явищ

I. В. Паризький. Специфіка комерціалізації послуг юридичного консалтингу в Україні...... 68

\section{ПРОБЛЕМИ ПРАВООХОРОННОЇ ДІЯЛЬНОСТІ}

І. О. Волокітенко. Шляхи вдосконалення діяльності превентивних підрозділів

Національної поліції України у сфері дотримання прав та свобод людини.. 73

О. В. Карнаухов. Антологія криміналістичного забезпечення (зміст системи, категорія та їі критеріі) .78

О. О. Кирбят’єв. Суб’єктивна сторона складів злочинів, передбачених статтями 342 та 345 КК України .85

О. М. Скрябін. Слідчі дії як основний засіб збирання доказів у кримінальному провадженні 90

\section{МІЖНАРОДНЕ ПРАВО}

I. М. Жуков. Актуальні питання міжнародно-правового регулювання розрахункових відносин.

\section{ТРИБУНА МОЛОДОГО НАУКОВЦЯ}

Ш. Б. Давлатов, А. В. Асєєва. Примушування до шлюбу в аспекті протидії домашньому насильству: криміналізація та іноземний досвід. 


\section{CONTENTS}

\section{HISTORY AND THEORY OF LAW}

Ye. S. Durnov. Legal status of the bar in 1919-1939 on the ethnic lands of Ukraine within Poland and Czechoslovakia......

V. R. Nestor. City government in the United Kingdom: the beginnings.

\section{ADMINISTRATIVE AND CUSTOMS LAW}

Yu. V. Borisova. Proceedings in cases of administrative offences related to corruption: a general theoretic aspect

S. V. Kononenko. Tax administration object in the field of excisable goods circulation

Ye. O. Leheza. Features of control during the provision of administrative services in order to prevent corruption risks.

R. V. Mazuryk. The implementation of the Anti-Corruption Strategy for 2020-2024

in the activities of the prosecutor's office.

O. P. Makhmurova-Dyshliuk. Human and citizen's rights and freedoms in armed conflict as an object of administrative and legal support

Ye. A. Kobrusieva. Judicial proceedings in peaceful assembly proceedings.

N. F. Skliar. Principles of financial responsibility for violation of tax legislation.

A. V. Tarasyuk. Theoretical and legal basis of information ethics in the cyber security system.

T. I. Shynkar. Judicial protection of the right to access public information

\section{CIVIL LAW}

O. O. Biliaiev. Features of responsibility in the field of sports 57

S. V. Zavalnyuk. The problems of correlation of the concept of a gap

in the civil legislation and some similar law concepts and phenomena.

I. V. Paryzkyi. Specificity of commercialization of legal consultancy services in Ukraine.

\section{PROBLEMS OF LAW ENFORCEMENT ACTIVITIES}

I. O. Volokitenko. Ways to improve the activities of preventive units of the National Police of Ukraine in the field of human rights and freedoms.

O. V. Karnauhov. Anthology of criminalistics providing (system variable, category and its standard) 78

O. O. Kyrbiat'iev. The subjective side of the corpus delict under articles 342 and 345

of the Criminal Code of Ukraine. 85

O. M. Scriabin. Investigative actions as the main means of collecting evidence in criminal proceedings

\section{INTERNATIONAL LAW}

I. M. Zhukov. Topical issues of international legal regulation of settlement relations. 


\section{TRIBUNE OF A YOUNG SCIENTIST}

Sh. B. Davlatov, A. V. Asieieva. Forced marriage in the aspect of combating domestic violence: criminalization and foreign experience...... 
УДК 340.75(477)

DOI https://doi.org/10.32836/2521-6473.2020-4.1

Є. С. Дурнов, доктор юридичних наук, доцент, професор кафедри історії, держави та права Національної академії внутрішніх справ

\section{ПРАВОВЕ СТАНОВИЩЕ АДВОКАТУРИ В 1919-1939 РОКАХ НА ЕТНІЧНИХ ЗЕМЛЯХ УКРАЇНИ У СКЛАДІ ПОЛЬЩІ ТА ЧЕХОСЛОВАЧЧИНИ}

У статті з'ясовано, щзо особливістю діяльності адвокатури у другій Польській республіці була певна хаотичність ї̈ устрою, обумовлена ї̈ формуванням із територій, щзо входили до складу трьох різних держав із власними правовими системами. Це відбилося на адвокатурі, яка існувала на українських землях, щзо у міжвоєнний період входили до складу Польщі. Так, адвокатура на українських землях до 1932 року фактично функиіонувала у двох різних правових режимах. Після відновлення польської держави австрійське законодавство про адвокатуру продовжувало діяти для Галичини до 1932 року. Відповідно до Положення про адвокатуру 1868 року, адвокатські палати складалися з усіх адвокатів, внесених до списків, які прожсивали на території відповідної палати. Адвокатські палати здійснювали свою діяльність частково безпосередньо через свої пленарні збори, частково через комісію адвокатської палати. Визначено, щзо адвокати із Закарпаття, об 'єднані в рамках «Союзу адвокатів Підкарпатської Русі» (з кіния 1938 року - «Союз адвокатів Карпатської України»), протягом усього часу існування Чехословаччини, вживали всіх можливих заходів для законодавчого вирішення питання про створення на території тодішнього Закарпаття окремої адвокатської палати, в чому полягає їх роль та заслуга в процесах організащійно-правового розвитку адвокатури на Закарпатті. Досліджено правове становище адвокатури на етнічних землях України у складі Чехословаччини та Польщі. Відзначено, щуо законодавство, яке регулювало питання діяльності адвокатів того часу, було досить прогресивним та визначало не тільки основні правові підстави діяльності адвокатів, але й порядок дисииплінарного провадження щзодо адвокатів. Наголошено на тому, щзо престижність адвокатської діяльності та існування відповідного законодавства на етнічних землях Украӥни у складі Чехословаччини привели до швидкого зростання кількості адвокатів. Зроблено висновок, щчо адвокатура у Польщі у міжвоєнний час частково формувалась на засадах адвокатського самоврядування, в останнє передвоєнне десятиліття посилилися тендениії до втручання держави у діяльність адвокатури, посилення впливу на неї виконавчої влади (через контроль з боку міністра юстиції, участь призначених президентом осіб у діяльності головної адвокатської ради).

Ключові слова: изентральна влада, міжнародні відносини, законодавство, реєстр адвокатів.

Ye. S. Durnov. Legal status of the bar in 1919-1939 on the ethnic lands of Ukraine within Poland and Czechoslovakia

The article finds out that the peculiarity of the activity of the bar in the second Polish Republic was a certain chaos of its structure, due to its formation from the territories that were part of three different states with their own legal systems. This was reflected in the bar, which existed in the Ukrainian lands, which in the interwar period were part of Poland. Thus, the bar in the Ukrainian lands until 1932 actually functioned in two different legal regimes. After the restoration of the Polish state, Austrian legal legislation continued to apply to Galicia until 1932. According to the Bar Regulations of 1868, the Bar Associations consisted of all lawyers included in the lists residing in the territory of the respective Chamber. The Bar Associations carried out their activities partly directly through their plenary meetings and partly through the commission of the Bar Association. It is determined that lawyers from Transcarpathia, united within the "Union of Lawyers of Subcarpathian Russia" (since the end of 1938 "Union of Lawyers of Carpathian Ukraine"), throughout the existence of Czechoslovakia took all possible measures to legislate the establishment of the then Transcarpathia a separate bar association. What is their role and merit in the processes of organizational and legal development of the bar in Transcarpathia. The legal status of the bar in the ethnic lands of Ukraine as part of Czechoslovakia is studied. It is noted that the legislation governing the activities of lawyers at that time was quite progressive and determined the basic legal basis not only for the activities of lawyers, but also the procedure for disciplinary proceedings against lawyers. It is emphasized that the prestige of advocacy and the existence of relevant legislation in the ethnic lands of Ukraine within Czechoslovakia has led to a rapid increase in the number of lawyers. It is concluded that the development of advocacy in Bukovina during the Romanian rule is characterized by the difficulty of unification of the legislation on advocacy after its accession to Romania, the growth of the bar (Bukovina bureau became the second largest in Romania), simplification of the system of obtaining a bar, the autonomy of this institution and the authority among the population. Despite the fact that the bar in Poland in the interwar period was partly formed on the basis of bar self-government, in the last prewar decade the tendencies of state interference in the bar increased, the influence of the executive branch on it increased activities of the main bar council).

Key words: central government, international relations, legislation, register of lawyers.

Постановка проблеми. Особливістю діяльності адвокатури у другій Польській республіці була певна хаотичність їі устрою, обумовлена іiі формуванням із територій, що входили до складу трьох різних держав iз власними правовими системами. Це відбилося на адвокатурі, яка існувала на українських землях, що

(C) С. С. Дурнов, 2020 
у міжвоєнний період входили до складу Польщі. Так, адвокатура на українських землях до 1932 року фактично функціонувала у двох різних правових режимах.

Метою статті є розгляд правового становища адвокатури в 1919-1939 роках на етнічних землях України у складі Польщі та Чехословаччини.

Виклад основного матеріалу. Для колишніх земель Російської імперії (до яких належали сучасні Волинська та Рівненська області) діяв Тимчасовий статут Палестри (адвокатури) Польської держави, затверджений декретом Начальника держави від 24 грудня 1918 року. На землях же, які до утворення Польщі входили до складу Австро-Угорщини (сучасні Львівська, Івано-Франківська та Тернопільська області), до 1932 року зберігався старий австрійський правовий режим регулювання адвокатської діяльності 3 певними модифікаціями [1, с. 35]. Так, на Галичині зберігав силу старий австрійський закон про адвокатуру від 6 липня 1868 року.

Тимчасовий статут закріпив організацію адвокатури, базуючись на засадах іiї самоврядності. Її основу склали адвокатські палати, які складалися 3 адвокатів та адвокатських аплікантів, зареєстрованих на території округу певного апеляційного суду (при цьому території округів не збігалися з адміністративнотериторіальним устроєм, включаючи землі відразу декількох воєводств) [2, с. 20]. Тимчасовий статут також допускав можливість створення головною адвокатською радою декількох адвокатських палат на території одного судового округу. Отже, волинські адвокати були об'єднані в Луцьку палату (хоча територіально ці землі належали до Люблінського судового округу). Пізніше закон 1932 року вилучив цей виняток. Отже, після 1932 року Луцька палата була включена до складу Люблінської палати.

Тимчасовим статутом було встановлено, що органами адвокатської палати були загальні збори палати та рада палати.

В загальних зборах адвокатів брали участь усі адвокати, що провадили діяльність на території відповідної адвокатської палати; за згодою голови зборів у них могли брати участь також адвокатські апліканти (щоправда, без права голосу). Основними функціями зборів були обрання членів ради адвокатської палати та представників палати у головній адвокатській раді, затвердження кошторису адвокатської палати на рік, затвердження звітів ради адвокатської палати (зокрема, фінансового), розгляд пропозицій ради та членів адвокатської палати стосовно адвокатської діяльності та діяльності ради.

Рада визначалася представницьким органом адвокатської палати. До їі функцій належали реєстрація (внесення до списків) адвокатів та адвокатських аплікантів; нагляд за належним виконанням професійних обов'язків членами адвокатури та дотриманням ними професійної етики; здійснення дисциплінарного провадження щодо адвокатів та адвокатських аплікантів; управління коштами адвокатської палати; керівництво професійною підготовкою та складанням іспитами адвокатськими аплікантами; скликання загальних зборів адвокатської палати та звітування на них тощо. Очолював раду декан, що обирався їі членами зі свого складу. Строк повноважень членів ради складав три роки, причому щороку ії склад оновлювався на третину.

Керівним органом адвокатури на загальнодержавному рівні виступала головна адвокатська рада. До iï повноважень, зокрема, належали представництво інтересів адвокатури; тлумачення статуту адвокатури; встановлення стандартів професійної етики; визначення програми підготовки та іспитів для адвокатських аплікантів; нагляд за адвокатськими палатами та їхніми радами; апеляційний або контрольний розгляд рішень адвокатських палат та їх рад, а також рішень у дисциплінарних провадженнях; ведення реєстру адвокатів та адвокатських аплікантів, його щорічне надання міністрові юстиції. Делегати до головної ради обиралися загальними зборами адвокатських палат строком на два роки (зі щорічним оновленням половини складу) [3].

Декрет про тимчасовий статут адвокатури Польської держави встановлював, що адвокатом може стати громадянин Польської держави незалежно від статі, який закінчив юридичний відділ національного університету; пройшов судову та адвокатську аплікацію та склав судовий і адвокатський іспит; є бездоганним у моральному аспекті.

Інститут аплікації (стажування) передбачав працю апліканта в канцелярії практикуючого адвоката (патрона) протягом двох років. Положення Тимчасового статуту фактично означали вимогу двоступеневого стажування: перед власне адвокатською аплікацією кандидат в апліканти мав пройти дворічну судову аплікацію (стажування в судових органах) і скласти відповідний іспит. Водночас Тимчасовий статут звільняв від необхідності проходження аплікації та складання адвокатського іспиту осіб, що мали досвід іншої правничої роботи (наприклад, судді, прокурори, підпрокуратори, іпотечні писарі).

Певні особливості мала адвокатська діяльність на колишніх австрійських землях. Адвокатські палати тут мали вже достатньо давню історію та існували ще з другої половини XIX століття [4]. На момент входження цих земель до складу Польщі галицькі адвокати були об'єднані у три адвокатські палати, а саме Львівську, Перемишльську та Самбірську (пізніше, після прийняття закону 1932 року, дві останні були включені до складу Львівської). Після відновлення польської держави, як і було зазначено вище, австрійське законодавство про адвокатуру продовжувало діяти для Галичини до 1932 року. Відповідно до Положення про адвокатуру 1868 року (досі, до речі, чинного в самій Австрії), адвокатські палати складалися з усіх адвокатів, внесених до списків, які проживали на території відповідної палати. Адвокатські палати здійснювали 
свою діяльність частково безпосередньо через свої пленарні збори, частково через комісію адвокатської палати. Очолював палату президент, який обирався (разом зі своїм заступником та членами комісії) пленарними зборами строком на три роки.

Колишні австрійські землі мали свої особливості стосовно вимог до адвоката. Так, замість поняття «адвокатський аплікант» в Австро-Угорщині, а пізніше і у землях, які входили до ії складу, використовувалося поняття «адвокатська кандидатура». На відміну від передбаченого Тимчасовим статутом загального строку аплікації у 4 роки, австрійське законодавство вимагало семирічного стажування, причому перший рік стажування проходив в одному із судових трибуналів, решта шість - при канцелярії практикуючого адвоката. Іншою вимогою до кандидата було здобуття ступеня доктора права (причому встановлювалося, що не менше трьох зі встановлених шести років практики при канцелярії адвоката слід було пройти вже після здобуття цього ступеня) [5, с. 245-246].

Незважаючи на певні відмінності в організації діяльності, адвокатські палати, що існували на колишніх австрійських землях, були інтегровані в загальну структуру польської адвокатури. Таким чином, у Польщі від початку склалася дворівнева система адвокатського самоврядування: на місцевому рівні вона була представлена адвокатськими палатами, на національному рівні діяла головна адвокатська рада, що представляла спільні інтереси адвокатських палат усієї країни.

У 1932 році був виданий президентський указ (в рамках тимчасового посилення президентських повноважень), яким був затверджений закон про устрій адвокатури. Він запровадив певні доповнення в організаційну структуру адвокатського самоврядування. Передусім, як було зазначено вище, були скасовані територіальні відмінності щодо порядку здійснення адвокатської діяльності, отже, для всієї території Польщі встановлювалося єдине законодавство у цій сфері.

Разом з уніфікацією структури адвокатського самоврядування новий акт приніс негативні зміни. Так, закон 1932 року достатньо сильно обмежував адвокатське самоврядування та посилював наглядові функції міністра юстиції щодо нього. Зокрема, актом передбачалась можливість за певних обставин розпуску ради адвокатської палати міністром юстиції та призначення для управління палатою тимчасових уповноважених, скасування рішень адвокатських рад, тимчасового закриття реєстру адвокатів для вписування нових членів. Міністрові надавалися ті самі контрольні повноваження щодо головної адвокатської ради, які остання мала щодо рад адвокатських палат [6, с. 68]. Подібні обмеження були пов'язані з посиленням авторитарних тенденцій у Польщі («режим санації»). Ще більших обмежень зазнало адвокатське самоврядування 3 прийняттям 4 травня 1938 року нового закону про устрій адвокатури. Так, зазнала змін структура головної адвокатської ради, до складу якої, окрім обраних адвокатськими палатами представників, увійшли 13 членів, призначених президентом, та 6 членів, обраних самою радою. При Верховному Суді утворювалась палата у справах адвокатури, завданням якої був розгляд у другій інстанції скарг прокурора щодо відмов окружних адвокатських рад щодо внесення до реєстру адвокатів (адвокатських аплікантів) або вилучень осіб з реєстру адвокатів [7].

Стосовно Закарпаття слід зазначити, що серед паризьких миротворців не в останню чергу завдяки активній дипломатичній діяльності чехословацької делегації, а також із геополітичних міркувань - максимального звуження кордонів Росії та Німеччини, вже від самого початку роботи конференції утвердилася спільна думка про те, що Закарпаття має стати частиною новоутвореної Чехословацької Республіки. За згодою держав Антанти чехословацькі війська вже 12 січня 1919 року зайняли західні регіони краю до річки Уж, включаючи м. Ужгород. Румунські власті протягом січня-березня 1919 року самовільно окупували східні райони Закарпаття у верхів'ях річки Тиса, мотивуючи це тим, що там проживає більшість румунів, які бажають жити в складі Румунії. В цій складній військово-політичній ситуації і в самому Закарпатті посилюється прочехословацька орієнтація щодо подальшої долі краю. 7 січня 1919 року спочатку частина Пряшівської Народної Ради на чолі з А. Бескидом висловилася за злуку з ЧСР [8].

Першим нормативним актом, який визначав правовий статус органів державного управління на території краю, став «Генеральний статут про організацію адміністрації Підкарпатської Русі, приєднаної Паризькою конференцією до Чехословацької республіки» (18 листопада 1919 року). Згідно 3 прийнятим чехословацькою владою Генеральним Статутом, Директорію було визначено дорадчим органом у всіх внутрішньо-автономних справах. Адміністратор разом із військовим командуючим концентрував у своїх руках усю виконавчу владу. Якщо, згідно з договорами, до компетенції центральної влади належали міжнародні відносини та управління військами й фінансами, то у всіх інших справах автономія отримувала певну самостійність. Проте з часом домовленості між урядом Чехословаччини та представниками Підкарпатської Русі привели до суттєвого звуження кола питань, що були віднесені до компетенції автономії [9].

Упродовж 1919-1920 років чехословацький уряд провів реорганізацію адміністративно-територіального устрою на Підкарпатській Русі. Було встановлено поділ на чотири жупи (жупне обводи), які оділялись на окреси (округи). Таким чином, утворили Ужгородську жупу (лютий 1919 року), Мукачівську жупу (травень 1919 року), Берегівську жупу (вересень 1919 року) [10, с. 60].

Запровадження тимчасового правового порядку в діяльності адвокатури ЧСР, на жаль, не вирішувало питання правового дуалізму. Закарпатські адвокати у досліджуваний період перебували у доволі невигід- 
ному становищі через відсутність власної адвокатської контори й водночас повноправно не відносились до новоствореної об'єднаної штори у Турчанському-Святому-Мартиш. На них поширювались повноваження Дисциплінарного сенату, який тільки здійснював дисциплінарні повноваження щодо них. Організаційно-правові питання вирішував голова крайового суду в Ужгороді разом з діючим при ньому дорадчим комітетом. Слід зазначити, що поширення на закарпатських адвокатів влади дисциплінарного сенату об'єднаної контори у Турчанському-Святому-Мартині привело до того, що ця контора розглядала дисциплінарні справи адвокатів, які не були її членами і навіть не могли бути представлені у складі її адміністративного комітету, адже до нього могли входити тільки члени контори.

У другій половині 30-х років XX століття організаційно-структурна побудова адвокатури Закарпаття зазнала деяких змін, зміст яких обумовило рішення Віденського арбітражу про включення частини території тодішньої Підкарпатської Русі з містами Ужгород та Мукачево до юрисдикції Угорщини. Зокрема, міністерством судівництва в Хусті в грудні 1938 року було уповноважено голову крайового суду у Великому Березному вести справи адвокатів Підкарпатської Русі, за винятком питань про їх дисциплінарну відповідальність, що й надалі належало до компетенції дисциплінарного сенату адвокатської палати в Турчанському-Святому-Мартині. Незважаючи на це, адвокати із Закарпаття, об'єднані в рамках «Союзу адвокатів Підкарпатської Русі» (з кінця 1938 року - «Союз адвокатів Карпатської України»), протягом усього часу існування Чехословаччини вживали всіх можливих заходів для законодавчого вирішення питання про створення на території тодішнього Закарпаття окремої адвокатської палати, в чому полягає їх роль та заслуга в процесах організаційно-правового розвитку адвокатури на Закарпатті. Однак політична ситуація в краї та його окупація Угорщиною у 1939 році не дали їм змоги, зрештою, реалізувати право на об’ єднання в рамках окремої адвокатської палати [11, с. 196].

Висновки $з$ дослідження і перспективи подальших розвідок у цьому напрямі. Отже, незважаючи на те, що адвокатура у Польщі у міжвоєнний час частково формувалась на засадах адвокатського самоврядування, в останнє передвоєнне десятиліття посилилися тенденції до втручання держави у діяльність адвокатури, посилення впливу на неї виконавчої влади (через контроль з боку міністра юстиції, участь призначених президентом осіб у діяльності головної адвокатської ради). Наголошено на тому, що престижність адвокатської діяльності та існування відповідного законодавства на етнічних землях України у складі Чехословаччини привели до швидкого зростання кількості адвокатів.

\section{Список використаних джерел:}

1. Tabaszewski R. Adwokcai Nowego Sącza do 1945 roku. Nowy Sącz, 2014. 106 s.

2. Mazur E. Organizacja adwokatury w latach 1918-1988. Palestra. 1988. T. 32. Numer 11-12 (371-372). S. 20-41.

3. Dekret Naczelnika Państwa w przedmiocie statutu tymczasowego Palestry Państwa Polskiego. Dziennik Praw Państwa Polskiego. 1918. Numer 22. Pozycja 75. S. 171-181

4. Гловацький I. Заснування та правовий статус адвокатських палат у Галичині в другій половині XIX ст. Науковий вісник Львівського державного університету внутрішніх справ. 2008. № 2. С. $17-21$.

5. Kotliński T. Kandydatura adwokacka w Galicji w latach 1849-1932. Palestra. 2012. Numer 9-10. S. 243-254.

6. Krzemiński Z. Adwokatura polska w latach 1918-1939. Palestra. $1988 . \quad$ T. 32. Numer 11-12 (371-372). S. 59-75.

7. Ustawa z dnia 4 maja 1938 r. Prawo o ustroju adwokatury. Dziennik Ustaw Rzeczypospolitej Polskiej. 1938. Numer 33. Pozycja 289. S. 531-548.

8. Віднянський С. Проблема самовизначення і розв'язання питання про державну приналежність Закарпаття після Першої світової війни. Проблеми історї України. URL: https:joanerges.livejournal.com/ 624415.html.

9. Політична інтеграція до Чехословацької Республіки. URL: http:www.zakarpatia.com/?p=815.

10. Закарпаття 1919-2009 років: історія, політика, культура / україномовний варіант українськоугорського видання / за ред. М. Вегеша, Ч. Фединець ; редколег.: Ю. Остапець, Р. Офіцинський, Л. Сорко, М. Токар, С. Черничко ; відп. за вип. М. Токар. Ужгород : Ліра, 2010. 720 с.

11. Фельцан I. Особливості організаційно-правового розвитку інституту адвокатури на Закарпатті в міжвоєнний період (1919-1939рр.). Правові та інституційні механізми забезпечення розвитку Украӥни в умовах європейської інтеграції: матеріали Міжнародної науково-практичної конференції (м. Одеса, 18 травня 2018 року) : у 2 т. Т. 1 / відп. ред. Г. Ульянова. Одеса : Видавничий дім «Гельветика», 2018. С. 194-196. 
УДК 342.25

DOI https://doi.org/10.32836/2521-6473.2020-4.2

\author{
В. Р. Нестор, \\ кандидат юридичних наук
}

\title{
ЗАРОДЖЕННЯ МІСЬКОГО САМОВРЯДУВАННЯ У СПОЛУЧЕНОМУ КОРОЛІВСТВІ
}

Метою статті є дослідження зародження міського самоврядування у містах Сполученого Королівства Великобританії і Північної Ірландї.

Доведено, щя аналогічна української ситуачія мала місие у Сполученому Королівстві: до певного етапу історичного розвитку міські населені пункти існували, однак вони не мали такого міського самоврядування, яке було б цікавим у сучасних умовах для дослідників изього питання. Лише Норманське завоювання змінило ичю ситуацію. Таким чином, якщчо на українські середньовічні міста впливало німецьке міське право, то на британські - франиузьке міське право.

Ознайомлення з історичними документами та прачями відомих учених дає підстави дійти висновку, щзо нормани сприяли утворенню міських населених пунктів, тому щьо їм так було легше утримувати владу на Британський островах. Поширити вплив на міський населений пункт було більш ефективно, ніж на сільський, адже менші зусилля приводили до кращчх результатів щзодо охоплюваної кількості людей. Норманське захоплення принесло ичентралізовану публічну владу, більш жорстку ієрархію органів публічної влади з підпорядкуванням нижчестоящих органів вищестоящим.

Варто підкреслити, щзо таку саму політику «урбанізації» англійські монархи проводили дещзо пізніше щзодо територій Уельсу, Шотландї.

Ознайомлення з британськими хартіями міста дає підстави стверджувати, щуо вони мають менший інтерес для сучасних дослідників, ніж магдебурзькі та хелмінські міські хартії, тоді як магдебурзькі та хелмінські хартії були пов'язані з наданням місту права на самоврядування переважно стосовно організаційної (та, відповідно, функціональної), британські міські хартії були найбільш цінними тим, щзо гарантували звільнення від одного чи кількох видів податків та зборів. Наприклад, якщо у континентальних європейських містах, відповідно до хартії, городяни могли самостійно формувати міський суд, то у британських містах (в усіх без винятку) функціонували королівські суди. Лише поодинокі місиеві населені пункти мали право обирати суддю (јиstice), який розглядав кримінальні справи (усі інші судді призначалися монархом). Позиція шерифа також завжди заміщувалась монархом.

Ключові слова: міське самоврядування, місиеве самоврядування, місто, міська територіальна громада, територіальна громада, публічна влада.

\section{R. Nestor. City government in the United Kingdom: the beginnings}

The aim of the article is to study the emergence of urban self-government in the cities of the United Kingdom of Great Britain and Northern Ireland.

A significant number of researchers have addressed and continue to address historical issues related to the emergence and development of local self-government in general and urban self-government in particular. Local self-government in the studied states is no exception.

Despite the fact that issues of local self-government have been in the spotlight for a long time, they are mostly studied in general in relation to the level of settlements, or in relation to the level of districts, regions. It is noteworthy that in the Ukrainian legal literature quite a few works are devoted exclusively to urban self-government.

It is proved that a similar Ukrainian situation took place in the United Kingdom - before a certain stage of historical development, urban settlements existed, however, they did not have such urban self-government, which would be interesting in modern conditions for researchers on this issue. And only the Norman Conquest changed this situation. Thus, if the Ukrainian medieval cities were influenced by German city law, the British - French city law.

Acquaintance with historical documents and works of famous scholars gives grounds to conclude: the Normans contributed to the formation of urban settlements because it was easier for them to retain power in the British Isles. Extending the impact to the urban settlement was more effective than to the rural one-less effort led to better results in terms of the number of people covered. The Norman Conquest brought centralized public power, a stricter hierarchy of public authorities with the subordination of lower bodies to higher ones.

It is worth emphasizing that the same policy of "urbanization" was pursued by the English monarchs somewhat later in relation to the territories of Wales and Scotland.

Familiarity with the British charters of the city gives grounds to assert: they are of less interest to modern researchers than the Magdeburg and Helminth city charters. While the Magdeburg and Helminth charters were concerned with giving the city the right to self-government, mainly in terms of organization (and therefore function), the British city charters were most valuable in guaranteeing exemption from one or more taxes and fees. For example, if in continental European cities, according to the charter, citizens could form a city court on their own; in British cities - in all without exception-there were royal courts. And only a few local settlements had the right to elect a judge (justice), who considered criminal cases (all other judges were appointed by the monarch). The position of sheriff has also always been replaced by the monarch.

Key words: city government, local government, city, city territorial community, territorial community, public authority.

\section{(C) В. Р. Нестор, 2020}


Постановка проблеми. Значна кількість дослідників зверталась та продовжує звертатись до історичних питань, пов'язаних $з$ появою та розвитком місцевого самоврядування загалом та міського самоврядування зокрема. Не є винятком місцеве самоврядування у досліджуваних державах.

Незважаючи на те, що питання місцевого самоврядування перебувають у полі зору доволі давно, вони здебільшого досліджуються загалом щодо рівня населених пунктів або щодо рівня районів, областей. Привертає увагу те, що в українській юридичній літературі доволі небагато праць присвячено виключно міському самоврядуванню.

Традиційним є підхід, відповідно до якого слід спочатку звернути увагу на історію досліджуваного інституту, а вже потім аналізувати сучасні проблеми та виклики сьогодення. У такому разі дуже часто для їхнього подолання можна звернутися до національного історичного досвіду. Перевагами такого підходу буде, по-перше, те, що цей досвід вже апробований саме у цій державі, по-друге, те, що є можливість ретельно перевірити усі переваги та недоліки такого досвіду. Звернення до національних нормативних документів, публікацій вітчизняних учених, матеріалів мас-медіа не є утрудненим ані з точки зору мовного бар'єру, ані 3 точки зору доступу до цих джерел інформації.

3 точки зору порівняльного дослідження міського самоврядування в Україні та Сполученому Королівстві щодо останнього мають інтерес ті ж самі періоди, що й в українській національній історії, а саме зародження міського самоврядування та поява місцевого самоврядування у його сучасному розумінні.

Аналіз останніх досліджень і публікацій. Питання міського самоврядування у Сполученому Королівстві Великобританії і Північної Ірландії у порівняльному контексті з Україною поки що не аналізувалися. Щодо питань компаративного дослідження місцевого самоврядування у цих країнах загалом, то воно розроблялось лише професоркою Н.В. Мішиною [1-3]. Однак вона не публікувала праці, присвячені історії міського самоврядування у цій країні.

Мета статті полягає у дослідженні зародження міського самоврядування у містах Сполученого Королівства Великобританії і Північної Ірландії.

Виклад основного матеріалу. Перший період у Сполученому Королівстві - зародження міського самоврядування - має істотні відмінності від аналогічного українського періоду.

В юридичній літературі склалась думка про те, що «англо-американська модель місцевого самоврядування походить 3 місцевих громад та парафій, а також 3 міст середньовічної Англії, управління якими «вбудовувалось» в державну вертикаль управління країною» [4, с. 8]. Відомий дослідник сім’ї загального права Г.Дж. Берман підкреслив, що «у європейському Середньовіччі було закладено основи індивідуалізму, автономії особистості, поваги до життя людини, іiї здоров'я і гідності, було проголошено напрям на забезпечення свободи та рівності у суспільстві, - іншими словами, сформульовані основні цінності сучасної західної цивілізації» [5, с. 336]. Не є винятком і Сполучене Королівство.

Слід зауважити, що, на відміну від більшості інших європейських країн, магдебурзьке, хелмське право не здійснило впливу на міське управління у Сполученому Королівстві. О.Б. Келлер підкреслює справедливість цього твердження, зазначаючи, що «магдебурзьке міське право - надбання загальної європейської спадщини, яке об’єднує велику частину сучасних держав старого континенту» [6, с. 24].

У працях цієї відомої білоруської дослідниці проблем німецького міського права є посилання на надзвичайно цікаві факти, які свідчать про те, що магдебурзьке право не було б чужорідним для Сполученого Королівства 3 джерельної точки зору, оскільки багато в чому спиралось на судові прецеденти. О.Б. Келлер, досліджуючи джерела магдебурзького права, запропонувала вважати, що «тлумачення змісту магдебурзького права можливо <..> лише під час звернення до конкретних судових рішень або зібрань вироків суду, посланих безпосередньо з Магдебурга в інші міста або таких, що з'явилися за межами власне Магдебурга. Йдеться як про юридичні ради шеффенів міста Магдебурга, так і про ради шеффенів інших міст, що судили за Магдебурзьким правом - перш за все це суди шеффенів міст Лейпцига і Галле. 3 судових рішень дрезденських шеффенів і шеффенів міста Дона також можна отримати чітке уявлення про зміст Магдебурзького права» [7, с. 41].

Варто нагадати, що в українських містах до впровадження німецького міського права у кількох його різновидах (магдебурзьке, хелмінське) фактично не було настільки прогресивного міського самоврядування, яке б нагадувало за своєю системою та самодостатністю управління державою. Також у цьому контексті слід наголосити на тому, що «магдебурзьке та хелмінське право за сутністю було міським правом. Міське право існувало і пізніше, за часів знаходження частин сучасної території України у складі Австро-Угорської та Російської імперій, хоча воно не було настільки розвиненим, як магдебурзьке та хелмінське право. І лише за часів радянської влади місцеве самоврядування у більшості сіл, селищ та міст було уніфіковано, що призвело до зникнення міського права» [8, с. 80].

Аналогічна ситуація була у Сполученому Королівстві, адже до певного етапу історичного розвитку міські населені пункти існували, однак вони не мали такого міського самоврядування, яке було б цікавим у сучасних умовах для дослідників цього питання. Лише Норманське завоювання змінило цю ситуацію. Таким чином, якщо на українські середньовічні міста впливало німецьке міське право, то на британські французьке міське право. 
Дослідники історії держави і права зарубіжних країн свідчать про те, що «до епохи нормандського завоювання Англії в країні склалося місцеве управління, яке не відрізнялося від місцевого управління в державах ранньофеодальної Свропи. Центральна влада не могла в той час утримувати розгалужений державний апарат на місцях, тому передавала завдання внутрішнього управління самоврядним групам, здійснюючи за ними нагляд» [9, с. 97].

До норманського завоювання територія південної частини Британських островів була поділена на графства, кожне з яких очолював старійшина. Велике значення мала й така посадова особа, як шериф, крім того, функціонували суди графств. Графства мали сільську структуру (міські населені пункти були відсутні), а для оподаткування і самоврядування кожні 10 домогосподарств утворювали групу (в межах якої збирали «десятину», ухвалювали рішення з важливих питань на загальних зборах), а кожні 10 груп - сотню. Сотні об'єднувались у графства. Цей уклад життя був сільським, феодальним та характеризувався як надзвичайно децентралізований з точки зору здійснення місцевого самоврядування зокрема та державного управління загалом.

Варто додати, що ще одна причина того, чому згадані вище адміністративно-територіальні одиниці середнього рівня (ланки) отримали назву сотні, полягала у тому, що в разі оголошення мобілізації кожна 3 таких одиниць мала представити для королівської армії 100 військових. 3 часом повноваження сотні ускладнялися та ставали все більш грунтовними. Так, проводились зібрання сотні (hundred-gemt, hundredmoot, формально у них могли брати участь усі жителі відповідної території, фактично на зібрання приходили та приймали рішення лише найбільш заможні жителі), згодом вони були замінені зібраннями представників (тенів). Кожна сотня скликала такі зібрання у кількості 12 представників. Поступово зібрання тенів отримали фіскальні, а згодом і судові повноваження. Організацію скликання та проведення таких зборів здійснював старійшина (hundreds-ealdor, hundred-man), який виступав на них головуючим.

Аналогічні зібрання проводились у графствах. Скликання, організацію та проведення зібрання представників забезпечували олдермен та його помічник (шериф). Олдермен обирався зборами представників сотен графства, а шериф призначався монархом, тому з часом шериф замінив олдермена, отримавши додатково до своїх усі повноваження цієї посадової особи.

Ознайомлення з історичними документами та працями відомих учених дає підстави дійти висновку, що нормани сприяли утворенню міських населених пунктів, тому що їм так було легше утримувати владу на Британських островах. Поширити вплив на міський населений пункт було більш ефективно, ніж на сільський, адже менші зусилля приводили до кращих результатів щодо охоплюваної кількості людей. Норманське захоплення принесло централізовану публічну владу, більш жорстку ієрархію органів публічної влади з підпорядкуванням нижчестоящих органів вищестоящим.

Варто підкреслити, що таку саму політику «урбанізації» англійські монархи проводили дещо пізніше по відношенню до територій Уельсу.

Відомий британський історик, дослідник ретроспективи міського самоврядування у Сполученому Королівстві Дж. Тейт відзначив, що «результатом Завоювання ${ }^{1} \epsilon$ справжній початок свідчень про муніципальну історію. Ми не маємо інформації щодо статусу донорманського міста, а тим більше жодної документації, судової чи адміністративної, на ту дату. Для цих останніх, справді, нам доведеться почекати до пізніших років XII століття, але 3 першого заснування нової династії зростає потік хартій» [10, с. 341]. У цьому узагальненні міститься важлива інформація щодо того, що, як і у Континентальній Свропі, на Британських островах міста мали свої права самоврядування, уміщені у хартії.

Дослідники свідчать про те, що найбільша частина хартій міським населеним пунктам була дарована королем Іоанном Безземельним, який таким чином прагнув поповнювати власну казну. Саме у цей період отримав хартію Лондон, а також такі старі міські населені пункти, як Вінчестер, Херефорд, Іпсвіч. Ці хартії збереглися, а історики, порівнюючи їхній зміст, говорять про те, що більшість положень цих документів $\epsilon$ ідентичною. Проте кожне місто під час отримання (у випадку з Іоанном Безземельним - під час придбання) хартій наполягало на включенні до цього документа тих важливих положень, які були актуальними для міського розвитку. Ці положення стосувались питань оподаткування, розвитку військових загонів, можливостей застосування озброєних формувань, розвитку торгівлі, розширенню кордонів міського населеного пункту тощо.

Слід підкреслити, що у ці часи не було такої адміністративно-територіальної одиниці, як «сіті». Міські населені пункти були представлені бургами й таунами. Як бурги, так і тауни мали королівський дозвіл на функціонування ринку (цей дозвіл видавався окремо від хартії), а розрізнялись ці адміністративно-територіальні одиниці за кількістю населення: бурги мали меншу кількість мешканців порівняно 3 таунами. Точних цифр та показників у законодавстві чи судових прецедентах тих часів закріплено не було, хоча історичні документи свідчать про численні спроби монархів впорядкувати це питання шляхом його регламентації у своїх документах (актах).

Дослідники-історики зазначають, що «вже у IX та особливо у ХІІ столітті отримали значне поширення ярмарки (Вінчестерська, Стенформська, у Йорку тощо), які відвідувались купцями не тільки з Франції, але

\footnotetext{
$\overline{{ }^{1} \text { Норманського завоювання - }}$ B. $H$.
} 
й з Італії, Німеччини та інших країн <..> 3 ростом міст як економічних центрів формувався і прошарок жителів міст. Найбільш значущі міста Британії були розташовані у королівському домені, тому жодне з англійських міст не змогло добитися самоуправління, міста були вимушені задовольнятися лише окремими економічними і фінансовими привілеями та частковим самоврядуванням, яке оформлювалось королівськими хартіями <...> За гроші вони часто придбавали права самоуправління та суду, яке обмежувало втручання королівських посадових осіб у справи міста» [11, с. 23].

Висновки 3 дослідження і перспективи подальших розвідок у цьому напрямі. Ознайомлення з британськими хартіями міста дає підстави стверджувати, що вони мають менший інтерес для сучасних дослідників, ніж магдебурзькі та хелмінські міські хартії. Тоді як магдебурзькі та хелмінські хартії були пов'язані з наданням місту права на самоврядування переважно в організаційному аспекті (та, відповідно, функціональному), британські міські хартії були найбільш цінними тим, що гарантували звільнення від одного чи кількох видів податків та зборів.

Наприклад, якщо у континентальних європейських містах, відповідно до хартії, городяни могли самостійно формувати міський суд, то у британських містах (в усіх без винятку) функціонували королівські суди. Лише поодинокі місцеві населені пункти мали право обирати суддю (justice), який розглядав кримінальні справи (усі інші судді призначалися монархом). Позиція шерифа також завжди заміщувалась монархом.

\section{Список використаних джерел:}

1. Мішина Н В. Територіальні громади та об'єднані територіальні громади в Україні. Наукові праці НУ OЮА. 2019. Т. 24. С. 75-80.

2. Мішина Н.В. Актуальні проблеми викладання муніципального права в Україні. Наукові прац̧і НУ ОЮА. 2016. Т. 15. С. 161-167.

3. Мішина Н.В. Деякі особливості муніципального управління в Лондоні. Актуальні проблеми держави і права : збірник наукових праць. Вип. 22. Одеса : Юридична література, 2004. С. 229-233.

4. Гураль П.Ф. Органи місцевого самоврядування у зарубіжних країнах : навчальний посібник. Львів : Каменяр, 2017. 147 с.

5. Берман Г.Дж. Западная традиция права / пер.с анг. 2-е изд. Москва : Инфра-М ; Норма, 1998. 624 с.

6. Келлер О.Б. Из истории городского права, правовых семей и сборников средневековой Германии. Известия Гомельского государственного университета имени Ф. Скориныл. 2015. № 1 (88). С. 24-30.

7. Келлер О.Б. Из истории магдебургского городского права. URL: https:/elib.bsu.by/ bitstream/123456789/167101/1/Келлер_4_2013-038-042.pdf.

8. Ідесіс І.В. Статути територіальних громад українських міст: проблеми теорії та практики : дис. ... канд. юрид. наук. Ужгород, 2016. 222 с.

9. Саликов Д.Х. Институт шерифов в системе местного управления средневековой Англии. Вестник Челябинского государственного университета. 2015. № 23. С. 97-101.

10. Tait J. Medieval English Borough: Studies on Origin and Constitutional History. Manchester : Manchester University Press, 1968. 372 p.

11. История стран Западной Европы : в 2 ч. Ч. 1 : Великобритания. Германия : учебник для академического бакалавриата. Москва : Юрайт, 2019. 356 с. 
УДК 342.95:328.185 (477)

DOI https://doi.org/10.32836/2521-6473.2020-4.3

Ю. В. Борисова, аспірант кафедри

адміністративного та митного права

Університету митної справи та фрінансів

\section{ПРОВАДЖЕННЯ У СПРАВАХ ПРО АДМІНІСТРАТИВНІ ПРАВОПОРУШЕННЯ, ЩО ПОВ'ЯЗАНІ З КОРУПЦІЮ: ЗАГАЛЬНОТЕОРЕТИЧНИЙ АСПЕКТ}

Стаття присвячена розгляду особливостей провадження у справах про адміністративні правопорушення, пов 'язані з корупиією. Визначено, щзо питання подолання корупиії у країні перебуває у тісному зв 'язку з процедурою притягнення правопорушників до адміністративної відповідальності. Зазначено, що питання визначення змісту провадження у справах про адміністративні правопорушення, пов'язані з корупцією, порівняно з провадженням у справах про адміністративні правопорушення не отримали належної уваги вчених-адміністративістів, не стали предметом комплексних наукових досліджень, хоча изей напрям дослідження є значним за обсягом та змістом.

Основною метою статті є визначення й аналіз особливостей провадження у справах про адміністративні правопорушення, пов'язані з корупиією, характеристика їх змісту, визначення специффіки їх реалізації.

Провадження у справах про адміністративні правопорушення, пов'язані з корупиією, є одним із способів забезпечення обов'язковості норм матеріального права та вжиття примусових заходів до порушників ичих норм, тому зазначений проиес має чітко відповідати вимогам закону, оскільки є процесуальною формою щодо притягнення до адміністративної відповідальності, порушення якої приведе до безкарності винних осіб.

Доведено, щз провадження у справах про правопорушення, пов'язані з корупцією, за обсягом питань, які вирішуються, кількістю суб'єктів, ще беруть участь, є одними з найскладніших проваджень в адміністративному праві.

Визначено, щзо провадження у справах про адміністративні правопорушення, щзо пов'язані з корупиією, - це процесуальна діяльність уповноважених органів (органів Національної полічії, Національного агентства із запобігання корупиії, судів тошо), яка на підставі норм адміністративного законодавства спрямована на встановлення об'єктивної істини у справі про адміністративне правопорушення, прийняття й виконання постанови по справі.

Ключові слова: адміністративна відповідальність, адміністративне правопорушення, законодавство, корупція, правопорушення, щчо пов 'язані з корупиією, провадження у справах про адміністративні правопорушення.

Yu. V. Borisova. Proceedings in cases of administrative offences related to corruption: a general theoretic aspect

The article is devoted to consideration of the peculiarities of proceedings in cases of administrative offenses related to corruption. It is determined that the issue of overcoming corruption in the country is in close connection with the procedure of bringing offenders to administrative responsibility. It is noted that the issue of determining the content of proceedings in cases of administrative offenses related to corruption in comparison with the proceedings in cases of administrative offenses did not receive due attention from the scientists-administrative, did not become the subject of comprehensive scientific research, although this direction of research is significant in scope and content.

The main purpose of the article is to determine and analyze the peculiarities of proceedings in cases of administrative offenses related to corruption, to characterize their content, to determine the specifics of their implementation.

Proceedings in cases of administrative offenses related to corruption are one of the ways to ensure the binding nature of substantive law and the application of coercive measures to violators of these rules, and therefore this process must clearly comply with the law, as it is a procedural form of prosecution, administrative liability, violation of which will lead to impunity for the perpetrators. It is proved that the proceedings in cases of corruption-related offences on the scope of issues that are resolved, the number of subjects participating is one of the most difficult proceedings in administrative law.

It is determined that the proceedings in cases of administrative offenses related to corruption are procedural activities of authorized bodies (bodies of the National Police, the National Agency for the Prevention of Corruption, courts, etc.), which on the basis of the norms of administrative legislation aimed at establishing objective truth in the case of administrative offense, adoption and execution of the resolution on the case.

Key words: administrative liability, administrative offenses, legislation, corruption, corruption-related offenses, administrative offenses.

Постановка проблеми. Адміністративний процес, як відомо, являє собою систему проваджень, які співвідносяться як загальне й особливе, поділяються на неюрисдикційні та юрисдикційні. До останніх належить провадження у справах про адміністративні правопорушення, різновидом якого є провадження у справах про правопорушення, пов’язані з корупцією, основним суб'єктом здійснення яких є посадові особи.

Незважаючи на прийняття нового антикорупційного законодавства, динаміка скоєних корупційних правопорушень залишається стабільною та стосується здебільшого саме суб'єктів, зобов'язаних забезпечувати дотримання антикорупційного законодавства та реалізовувати антикорупційну політику всієї держави.

(C) Ю. В. Борисова, 2020 
Питання подолання корупції в країні перебуває у тісному зв'язку з процедурою притягнення правопорушників до адміністративної відповідальності, тому зазначене питання є дуже актуальним.

Аналіз останніх досліджень і публікацій. Питання визначення змісту провадження у справах про адміністративні правопорушення, пов'язані з корупцією, порівняно з провадженням у справах про адміністративні правопорушення не отримали належної уваги з боку вчених-адміністративістів, не стали предметом комплексних наукових досліджень, хоча цей напрям дослідження $є$ значним за обсягом та змістом.

Загальним проблемам адміністративної відповідальності, зокрема питанням провадження у справах про адміністративні правопорушення, присвячена низка монографій, навчальних посібників, наукових статей, науково-практичних коментарів до законодавства таких авторів, як В.Б. Авер'янов, О.М. Бандурка, Ю.П. Битяк, А.С. Васильєв, І.П. Голосніченко, С.Т. Гончарук, Є.В. Додін, Л.В. Коваль, Д.П. Калаянов, С.В. Ківалов, Т.О. Коломоєць, А.Т. Комзюк, В.К. Колпаков, О.І. Миколенко, О.І. Остапенко, Д.В. Приймаченко, М.М. Тищенко, В.К. Шкарупа. Однак необхідно констатувати, що питання визначення особливостей провадження у справах про адміністративні правопорушення, пов'язані з корупцією, залишилися поза належної уваги науковців.

Мета статті полягає у визначенні та аналізі особливостей провадження у справах про адміністративні правопорушення, пов'язаних з корупцією, характеристиці їх змісту, визначенні специфіки їх реалізації.

Виклад основного матеріалу. Провадження у справах про адміністративні правопорушення, пов'язаних $з$ корупцією, є одним зі способів забезпечення обов'язковості норм матеріального права та вжиття примусових заходів до порушників цих норм, тому зазначений процес має чітко відповідати вимогам закону, оскільки є процесуальною формою щодо притягнення до адміністративної відповідальності, порушення якої приведе до безкарності винних осіб.

За функціональною ознакою у структурі адміністративного процесу можна виділити провадження, що мають установчий характер (провадження з утворення державних органів, суб'єктів підприємницької діяльності); провадження, що мають правотворчий характер (провадження з відпрацювання та прийняття нормативних актів); правоохоронні провадження (провадження у справах про адміністративні правопорушення, провадження за скаргами громадян); правонаділяючі провадження (провадження з реалізації контрольно-наглядових повноважень) [3, с. 211].

Провадження у справах про адміністративні правопорушення (проступки) є самостійним видом адміністративно-юрисдикційних проваджень. На нього поширюються всі загальні ознаки, властиві юрисдикційним адміністративним провадженням [1, с. 515]. Крім того, як зазначає І.Л. Бородін, «провадження у справах про адміністративні правопорушення є одним із найбільш об'ємних проваджень адміністративно-юрисдикційного процесу і порівняно з іншими провадженнями більш детально регламентоване адміністративно-процесуальними нормами» [2, с. 103].

На думку авторів підручника «Адміністративне право України» за загальною редакцією Ю.П. Битяка, В.М. Гаращука, В.В. Зуй, до основних особливостей провадження у справах про адміністративні правопорушення слід відносити такі:

1) провадження є одним із видів юрисдикційних проваджень, тобто проваджень, що пов'язані із застосуванням до осіб примусових заходів, передбачених адміністративним законодавством;

2) провадження являє собою юрисдикційну діяльність компетентних органів, тобто діяльність, що пов'язана з виявленням адміністративних проступків та притягненням винних до адміністративної відповідальності;

3) провадження у справах про адміністративні правопорушення складається з певних стадій, кожна 3 яких має як загальні, так і специфічні завдання та цілі [3, с. 130].

Продовжуючи аналіз поняття «провадження у справах про адміністративні правопорушення», спробуємо окреслити різні позиції науковців щодо цієї дефініції. На думку В.К. Колпакова, «провадження у справах про адміністративні проступки (адміністративно-деліктне провадження) - це процесуальна діяльність на підставі визначених законодавцем правил щодо встановлення об'єктивної істини у справі про адміністративний проступок і прийняття рішення відповідно до чинного законодавства» [4, с. 390]. О.В. Кузьменко, Т.О. Гуржій вважають, що «провадження у справах про адміністративні проступки - це нормативно врегульована діяльність повноважних суб'єктів із застосування адміністративної відповідальності за скоєний адміністративний проступок, а також попередження адміністративних правопорушень» [5, с. 224]. Іншої позиції дотримується O.I. Миколенко, який зазначає, що «провадження у справах про адміністративні правопорушення - це один із видів адміністративних юрисдикційних проваджень, що являє собою низку послідовних дій компетентних органів та осіб, передбачених чинним законодавством щодо виявлення адміністративних проступків та притягнення винних до адміністративної відповідальності під час адміністративного розслідування, розгляду й прийняття постанови (рішення) про накладення адміністративного стягнення» [6, с. 130]. Професор M.M. Тищенко надав таке визначення: «провадження у справах про адміністративні правопорушення - це низка послідовних дій уповноважених органів (посадових осіб), а у деяких випадках інших суб'єктів, які згідно 3 нормами адміністративного законодавства вживають заходів, що спрямовані на притягнення правопорушників до відповідальності і забезпечення виконання винесеної постанови [3, с. 219]. 
Відповідно до ст. 1 КУпАП, завданням Кодексу України про адміністративні правопорушення є охорона прав і свобод громадян, власності, конституційного ладу України, прав і законних інтересів підприємств, установ і організацій, встановленого правопорядку, зміцнення законності, запобігання правопорушенням, виховання громадян у дусі точного і неухильного додержання Конституції і законів України, поваги до прав, честі і гідності інших громадян, до правил співжиття, сумлінного виконання своїх обов'язків, відповідальності перед суспільством [7]. Зазначена стаття КУпАП, на думку І.Л. Бородіна, дає сумарну характеристику всього кола об'єктів протиправного посягання адміністративного проступку. Крім того, вона орієнтує правоохоронні органи не тільки на застосування доказів примусу до правопорушників, але й на активну виховну та профілактичну роботу, підвищення рівня свідомості громадян, їхню участь у боротьбі за недопущення правопорушень [8, с. 105].

Провадження у справах про правопорушення, пов'язані з корупцією за обсягом питань, які вирішуються, кількістю суб'єктів, що беруть участь, $є$ одним із найскладніших проваджень в адміністративному праві [9, с. 146]. Завданнями цього провадження, відповідно до ст. 245 КУпАП, є своєчасне, всебічне, повне та об'єктивне з'ясування обставин справи, вирішення ії в точній відповідності до законодавства, забезпечення виконання винесеної постанови, а також виявлення причин та умов, що сприяють вчиненню адміністративних правопорушень, запобігання правопорушенням, виховання громадян у дусі додержання законів.

У спеціальній літературі, як правило, виділяються такі чотири стадії провадження у справах про порушення митних правил:

- порушення справи про адміністративне правопорушення та розслідування;

- розгляд справи по суті та винесення по ній постанови;

- перегляд справи у зв'язку з оскарженням постанови у справі;

- виконання постанови у справі.

Справи про адміністративні правопорушення, пов'язані з корупцією, слід розглядати в контексті провадження у справах про адміністративні правопорушення, але з деякими особливостями, однак з урахуванням стадійності та логічної послідовності зазначених стадій виокремимо такі особливості притягнення до адміністративної відповідальності правопорушників корупційного законодавства на кожній стадії провадження.

1. Правозастовча практика виходить із того, що справа про адміністративне правопорушення вважається порушеною з моменту складання протоколу про адміністративне правопорушення, пов'язане 3 корупцією, однак ця позиція є не зовсім правильною через те, що чинний КУПАП не визначає конкректно процесуальний документ, який засвідчує факт розпочатої справи. Крім того, зазначений протокол має бути надісланий до суду за місцем вчинення адміністративного правопорушення в 3-денний термін, що значно ускладнює процес збирання доказів по справі, вжиття заходів із забезпечення провадження у справах про адміністративні правопорушення та підкріплення їх процесуальними документами.

2. Протокол про адміністративне правопорушення, пов'язані з корупцією, мають право складати працівники органів Національної поліції, за винятком правопорушень, вчинених службовими особами, які займають відповідальне та особливо відповідальне становище, а також Національного агентства 3 питань запобігання корупції.

3. Особа, яка склала протокол про вчинення адміністративного правопорушення, пов’язаного 3 корупцією, одночасно з надісланням його до суду надсилає органу державної влади, органу місцевого самоврядування, керівникові підприємства, установи чи організації, де працює особа, яка притягається до відповідальності, повідомлення про складання протоколу для розгляду питання щодо можливого відсторонення такої особи від виконання службових повноважень із зазначенням характеру вчиненого правопорушення та норми закону, яку порушено.

4. Адміністративне стягнення за вчинення правопорушення, пов'язаного з корупцією, а також правопорушень може бути накладено протягом шести місяців 3 дня його виявлення, але не пізніше двох років 3 дня його вчинення. Таким чином, строк накладення стягнення порівняно з іншими видами адміністративних правопорушень, що розглядається судами, збільшено вдвічі, при цьому законодавцем встановлюється термін строків давності притягнення правопорушників до адміністративної відповідальності, а саме 2 роки.

5. Справи про адміністративні правопорушення, пов'язані 3 корупцією, розглядаються виключно судами за місцем вчинення правопорушення. Розгляд справ відбувається одноосібно суддею суду загальної юрисдикції.

6. Під час розгляду зазначеної категорії справ участь прокурора є обов'язковою. Фактично це єдина категорія справ про адміністративні правопорушення, в яких участь прокурора $є$ його обов'язковою.

7. Особа, що притягується до адміністративної відповідальності за правопорушення, пов'язане з корупцією, зобов'язана бути присутньою під час розгляду справи в суді. В разі ухилення від явки до суду до неї може бути застосований примусовий привід, що забезпечується працівниками органів Національної поліції.

8. Строк розгляду справ про адміністративні правопорушення, пов'язані з корупцією, не має перевищувати 15 днів, що є складовою частиною строку накладення адміністративного стягнення за ці пра- 
вопорушення. Проте особливістю є те, що строк розгляду адміністративних справ про адміністративні правопорушення, пов'язані з корупцією, зупиняється судом, якщо особа, щодо якої складено протокол про таке правопорушення, умисно ухиляється від явки до суду або з поважних причин не може туди з'явитися (хвороба, перебування у відрядженні чи на лікуванні, у відпустці тощо).

9. Постанова суду про накладення адміністративного стягнення за адміністративне правопорушення, пов'язане $з$ корупцією, у триденний строк з дня набуття нею законної сили направляється відповідному органу державної влади, органу місцевого самоврядування, керівникові підприємства, установи чи організації, державному чи виборному органу, власнику юридичної особи або уповноваженому ним органу для вирішення питання про притягнення особи до дисциплінарної відповідальності, усунення ії згідно із законодавством від виконання функцій держави, якщо інше не передбачено законом, а також усунення причин та умов, що сприяли вчиненню цього правопорушення.

Висновки 3 дослідження і перспективи подальших розвідок у цьому напрямі. Підсумовуючи викладене вище, можемо зробити висновок, що у схематичному вигляді провадження у справах про адміністративні правопорушення, що пов'язані з корупцією, - це процесуальна діяльність уповноважених органів (органів Національної поліції, Національного агентства із запобігання корупції, судів тощо), яка на підставі норм адміністративного законодавства спрямована на встановлення об'єктивної істини у справі про адміністративне правопорушення, прийняття й виконання постанови по справі.

Таким чином, розгляд особливостей провадження у справах про адміністративні правопорушення, пов'язані з корупцією, сприятимуть, на нашу думку, охороні прав і свобод громадян, додержанню вимог законів під час притягнення осіб до адміністративної відповідальності за вчинення правопорушень, пов'язаних з корупцією, підвищенню оперативності та ефективності провадження у справах про адміністративні правопорушення, пов'язані з корупцією, посилять значення адміністративної відповідальності у системі засобів протидії корупції.

\section{Список використаних джерел:}

1. Адміністративне право України. Академічний курс : підручник : у 2 т. Т. 1 : Загальна частина / ред. В.Б. Авер'янов. Київ : Юридична думка, 2004. 584 с.

2. Бородін І.Л. Адміністративно-юрисдикційний процес : монографія. Київ : Алерта, 2007. 184 с.

3. Битяк Ю.П., Гаращук В.М., Богуцький В.В. та ін. Адміністративне право : підручник / за заг. ред. В.В. Зуй. Харків : Право, 2010. 624 с.

4. Колпаков В.К. Адміністративно-деліктний феномен : монографія. Київ : Юрінком Інтер, 2004. 528 с.

5. Кузьменко О.В., Гуржій Т.О. Адміністративно-процесуальне право України : підручник. Київ : Атика, 2007. $416 \mathrm{c}$

6. Миколенко А.И. Административный процесс и административная ответственность в Украине : учебное пособие. Харьков : Одиссей, 2006. 352 с.

7. Кодекс України про адміністративні правопорушення : прийнятий Верховною Радою Української РСР 7 грудня 1984 р. Відомості Верховної Ради Української РСР. 1984. Додаток до № 51. Ст. 1122.

8. Бородін І.Л. Адміністративно-юрисдикційний процес : монографія. Київ : Алерта, 2007. 184 с.

9. Гайдук А.В. Заходи адміністративного примусу у боротьбі з корупцією в Україні : дис. ... канд. юрид. наук : спец. 12.00.07. Київ, 2006. 202 с. 
УДК 347.73:336.22 (477)

DOI https://doi.org/10.32836/2521-6473.2020-4.4

\author{
С. В. Кононенко, \\ здобувач Науково-дослідного інституту публічного права
}

\title{
ОБ’ЄКТ АДМІНІСТРУВАННЯ ПОДАТКІВ У СФЕРІ ОБІГУ ПІДАКЦИЗНИХ ТОВАРІВ
}

У статті комплексно сформульовано актуальну наукову думку щзодо розуміння сутності об'єкта адміністрування податків у сфері обігу підакиизних товарів в Україні. У процесі критичного аналізу спеціальної наукової літератури автором з'ясовуються основні підходи украӥнських учених до розуміння сутності об'єкта адміністрування та об'єкта адміністрування податків. Грунтуючись на ичих підходах та зважаючи на сучасне розуміння концепціі «публічне адміністрування», доводиться, щзо об 'єкт адміністрування податків у сфері обігу підакиизних товарів сьогодні не може зводитись лише до погашення податкового зобов'язання платника акиизного податку. Досліджуваний об 'єкт розкривається як комплексний конструкт, який складають загальний та опосередкований об 'єкти адміністрування податків. Загальним об'єктом адміністрування податків у сфері обігу підакиизних товарів пропонується розуміти публічно-правовий обов'язок платника акиизного податку щчодо погашення податкового зобов'язання, а саме міру (стан) належного виконання обов 'язку щуодо: складання платником податку звітного документа; подання до відповідного контролюючого органу звітного документа (заяви, заявки); виконання податкового обов 'язку у частині погашення податкового зобов'язання; діяльності платника податку, що є учасником відносин із приводу адміністрування акиизного податку. Опосередкований об'єкт адміністрування податків у сфері обігу підакизиних товарів тлумачиться як міра (стан) створення належних умов щодо виконання платником податку податкового обов'язку у сфері обігу підакцизних товарів, а саме: реєстрація особи як платника акцизного податку; процеси, пов'язані з організацією та забезпеченням функиіонування механізму добросовісного виконання платниками акцииного податку податкового обов'язку. Зроблено висновок, щцо адміністрування податків у сфері обігу підакцизних товарів є складним соціально-правовим феноменом, що безпосереднім чином позначається на змісті його об'єкта. Зміст і юридична природа об'єкта адміністрування податків у сфері обігу підакиизних товарів суттєвим чином ускладнюється сучасним, орієнтованим на європейську доктрину адміністративного права розумінням публічного адміністрування. Так, якщо зводити адміністрування податків у сфері обігу підакиизних товарів до «управління прочесами виконання податкового обов 'язку», то об'єктом иього явища буде формальне справляння податків, щчо є типовим для держав, які сьогодні не розвиваються в межах парадигми людиночентризму, на якій трунтуються держави - члени СС.

Ключові слова: адміністрування податків, національна система адміністрування податків, об'єкт, підакичиний товар, суб 'єкти оподаткування, сутність об’єкта адміністрування податків, сфера обігу підакиизних товарів.

\section{S. V. Kononenko. Tax administration object in the field of excisable goods circulation}

The article formulates comprehensively the current scientific thought regarding the understanding of the essence of the tax administration object in the field of excisable goods circulation in Ukraine. While analyzing critically special scientific literature, the author clarifies the main approaches of Ukrainian scientists to understanding the essence of the object under administration and the one under tax administration. Based on these approaches and considering the modern understanding of the concept of "public administration", it is proved that the object of tax administration in the sphere of excisable goods circulation today cannot be reduced only to the repayment of the excise tax payer's tax liability. The object investigated is revealed as a complex construct, which consists of general and indirect objects of tax administration. The general object of tax administration in the sphere of excisable goods circulation is proposed to understand as the public-legal obligation of the excise tax payer to repay the tax liability, namely the measure (state) of the proper fulfillment of the obligation for: drawing up a reporting document by the taxpayer; submission to the relevant authority of a reporting document (statement, application) of the tax obligation fulfillment in terms of the tax obligation payment; activity of a taxpayer, who is a participant in relations regarding the excise tax administration. An indirect object of tax administration in the field of excisable goods circulation is interpreted as a measure (state) of creating appropriate conditions for the tax payer to fulfill the tax debt in the field of excisable goods circulation, namely: registration of a person as a payer of excise tax; processes related to the organization and maintenance of the functioning of the mechanism for the conscientious fulfillment of the tax debt by the excise tax payers. It is concluded that the administration of taxes in the field of circulation of excisable goods is a complex socio-legal phenomenon that directly affects the content of its object. The content and legal nature of the object of tax administration in the field of circulation of excisable goods is significantly complicated by the modern, focused on the European doctrine of administrative law understanding of public administration. Thus, if we reduce the administration of taxes in the circulation of excisable goods to "management of tax compliance processes", the object of this phenomenon will be the formal collection of taxes, which is typical for states that are not developing today within the paradigm of anthropocentrism. based on EU member states.

Key words: essence of the tax administration object, excisable goods, national tax administration system, object, sphere of the excisable goods turnover, tax administration, tax subjects.

\section{(C) С. В. Кононенко, 2020}


Постановка питання. Адміністрування податків у сфері обігу підакцизних товарів (далі - АПСОПТ) на сьогодні в Україні постає як складне соціально-правове явища, яке у практичній дійсності виявляється у: 1) системоутворюючій складовій частині процесу соціально-економічного розвитку країни; 2) формі реалізації владного впливу компетентних суб'єктів публічної адміністрації на відповідну сферу публічно-владних і суспільних зв'язків, які виникають і здійснюються з метою задоволення публічного інтересу в податковій сфері та виражаються в сукупності владних рішень і процедур контролюючих органів та в діях їх посадових осіб, що визначають інституційну структуру податкових та митних відносин, організовують ідентифікацію об’єктів оподаткування, забезпечують організацію та контроль за сферою обігу підакцизних товарів (далі ПТ) відповідно до порядку, встановленого законодавством.

Цілком закономірно, що дослідження адміністративно-правових засад АПСОПТ не може вважатись комплексним без з'ясування сутності та структури того, на що скеровує свій адміністративно-правовий вплив суб'єкт адміністрування відповідних податків, тобто без з'ясування адміністративно-правової характеристики керованої підсистеми (та елементів в ній) у межах системи АПСОПТ. Встановлення відповідних аспектів АПСОПТ має надзвичайно важливе теоретичне та практичне значення, зважаючи на таке: 1) суб'єкти адміністрування податків у досліджуваній сфері повинні дотримуватись принципу законності у значенні ч. 2 ст. 19 Конституції України, що у цьому сенсі означає: відповідні суб'єкти публічної адміністрації повинні діяти таким чином, щоби не виходити за межі свого правового статусу; 2) правовий статус суб'єктів АПСОПТ, а також форми, методи їхньої діяльності та процедури, які здійснюються такими суб'єктами, корегуються об’єктом і предметом відповідного адміністрування; 3) неналежне розуміння об'єкта та предмета АПСОПТ унеможливлює достатнє розуміння правового статусу вказаних суб'єктів (як самим суб'єктом адміністрування, так і іншими суб' єктами, зокрема контролюючими суб'єктами), а також збільшує ризики недобросовісного виконання такими суб'єктами власних повноважень.

Аналіз наукової літератури та невирішені раніше питання. Попри очевидну теоретичну та практичну важливість чіткого розуміння сутності об'єкта адміністрування податків, слід зазначити, що вітчизняними ученими ще не було комплексно досліджено об'єкт АПСОПТ, хоча об'єкту адміністрування податків загалом вже приділяли увагу О.В. Безкровний, А.О. Беспалова, О.С. Іванишина, А.І. Крисоватий, Р.Ю. Паславська, Р.М. Рачинський, В.І. Теремецький та інші вітчизняні учені. Ураховуючи сутність АПСОПТ, а також позиції вітчизняних учених щодо розуміння сутності об'єкта адміністрування податків, можемо визначити особливу сутність зазначеного елемента досліджуваного явища.

Відтак метою цієї наукової статті є формулювання актуальної наукової думки щодо розуміння сутності об'єкта АПСОПТ. Окреслена мета досягатиметься у процесі виконання таких дослідницьких завдань: 1) з'ясувати основні підходи вітчизняних учених до розуміння об'єкта адміністрування та об'єкта адміністрування податків; 2) встановити об'єкт АПСОПТ як комплексну категорію, що узгоджена із сучасним розумінням концепту «публічне адміністрування»; 3) узагальнити результати дослідження.

Виклад основного матеріалу дослідження. Об’єкт адміністрування вітчизняними ученими тлумачиться як «стосунки людей у процесі діяльності та відносин між представниками адміністрації з питань управління» [1, с. 10]. При цьому, критично аналізуючи спеціальні наукові дослідження, в яких окреслюється зміст об'єкта адміністрування податків, можемо помітити, що серед науковців відсутнє узгоджене розуміння відповідного конструкту. На цю обставину також звертає увагу Р.М. Рачинський, зауважуючи, що такий об'єкт науковці визначають переважно «як здійснення певного податкового обов’язку платником податків, тобто суб'єктом, та як сферу справляння податків» [2, с. 150]. Нами ж помічено більший перелік підходів до інтерпретації сутності, а саме: 1) розуміння об'єкта адміністрування податків як податкового обов'язку зобов'язаного суб'єкта (головним чином платника податків і зборів) [3, с. 87]; 2) розуміння об'єкта адміністрування податків як діяльності з виконання зобов'язаним суб' єктом податкового обов'язку [4, с. 23; 5, с. 183]; 3) розуміння об’єкта адміністрування податків як стану виконання податкового обов’язку платниками податку [6]; 4) розуміння об'єкта адміністрування податків як розпорядчої і виконавчої діяльності щодо функціонування режиму оподаткування [7, с. 290]; 5) розуміння об'єкта адміністрування податків як відносин, що виникають між суб'єктом адміністрування та суб'єктом, обтяженим податковим обов'язком; 6) розуміння об'єкта адміністрування податків, у рамках якого адміністрування податків ототожнюється із справлянням податків [8, с. 86]. Зазначимо, що практично кожен із вказаних підходів до розуміння об'єкта адміністрування податку є таким, що окреслює різні аспекти вияву феномена адміністрування податку. При цьому в широкому сенсі безпосереднім об'єктом АПСОПТ є саме податковий обов'язок суб' єктів, зобов'язаних сплачувати акцизний податок (далі - АП), який ученим розглядається у широкому та вузькому сенсах. Отже, узагальнюючи різні інтерпретації науковцями об'єкта адміністрування податків, доходимо думки, що в межах системного дослідження АПСОПТ об’єкт адміністрування податків у досліджуваній сфері є комплексним елементом, який можна поділити на такі види:

1. Загальний об'єкт АПСОПТ, яким є публічно-правовий обов'язок платників податку щодо погашення податкового зобов'язання, а саме міра (стан) належного виконання обов'язку щодо:

1) складання платником податку звітного документа. Платник податку, як зобов'язана сторона у відносинах із приводу АПСОПТ, повинен звітувати про свою діяльність, яка охоплена предметом відання суб'єкта 
АПСОПТ. Відтак звітні документи платника податку у цьому контексті постають як предмет розглядуваного адміністрування податків, адже контролюючий орган у межах АПСОПТ перевіряє такі документи на предмет їх належного складання (наявності повної, достовірної та правильно викладеної інформації; враховуючи також правильність висновків платника податку щодо сум податкового зобов’язання). Наприклад, перевіряючи декларацію АП, компетентний орган у відповідності до статей 46 і 48, підп. 213.1.12 п. 213.1 ст. 213 , підп. 215.3 .10 п. 215.3 ст. 215 і п. 223.2 ст. 223 ПК України, наказу Мінфіну України від 23 січня 2015 року № 14 перевіряє: а) цілісність документа (з’ясовується, чи містить поданий документ усі необхідні обов’язкові частини та елементи, зокрема, додатки до цієї декларації); б) повноту та правильність (адекватність) заповненої інформації (відповідність вказаного типу поданої декларації, коректність необхідних ідентифікаційних даних платника податку, найменування контролюючого органу, до якого вона подається, дати подання і т. д.; заповнення лише відповідних розділів і додатків до декларації, що відповідають виду господарської діяльності платника податку, виду ПТ); в) наявність підпису уповноваженої особи, якою підтверджується достовірність викладеної в документі інформації (керівника організації чи уповноваженої організацією особи, а також особи, яка відповідає за ведення бухгалтерського обліку та подання відповідних звітних документів до контролюючого органу; фізичної особи - платника податку чи його законного представника);

2) подання до відповідного суб'єкта АПСОПТ звітного документа (заяви, заявки). Збалансованість функціонування податково-правового режиму у сфері обігу ПТ забезпечується чітким порядком дій не лише суб’єктів АПСОПТ, але й платників податків у відносинах із контролюючим органом. Щонайперше це стосується питання порядку звітування платника податку про свою діяльність, який виявляється у правильному заповненні звітного документу та належному подані його до суб'єкта АПСОПТ, в якому платник перебуває на обліку. Не меншої уваги в цьому питання заслуговують і факти подання платниками податків заяв (заявок) на добросовісне виконання податкового обов'язку (зокрема, заявки на поповнення чи коригування залишку пального; заявки на поповнення або коригування залишку спирту етилового).

Вказані обставини щоразу перевіряються контролюючим органом, будучи об'єктом АПСОПТ. Перевіряючи відповідність подання декларації АП вимогам розділу ІІІ Порядку, затвердженого наказом Мінфіну України від 23 січня 2015 року № 14, або ж декларації про максимальні роздрібні ціни на ПТ (продукцію) вимогам розділу II Порядку, затвердженого наказом Мінфіну України від 25 березня 2015 року № 359, компетентний орган з'ясовує: а) вчасність подання звітного документа (заяви, заявки); б) дотримання правил територіальної юрисдикції під час подачі звітного документа (заяви, заявки); в) дотримання вимог до способу подання звітного документа (заяви, заявки);

3) виконання податкового обов’язку у частині погашення податкового зобов’язання. Як вже неодноразово зазначалось, на платника податку Конституцією та іншими законами України покладається публічноправовий обов'язок погашати власне податкове зобов'язання за звітний (податковий) період. Між тим відповідно до п. 1 розділу IV Порядку, затвердженого наказом Мінфіну України від 23 січня 2015 року № 14, платник податку повинен зазначити в декларації АП самостійно обчислювану ним суму податкового зобов'язання. Ця сума може змінюватись контролюючим органом (або ж у разі самостійної перевірки документа після його подання) в результаті перевірки відповідного документу (у разі виявлення факту недоплати, тобто заниження податкового зобов'язання минулих звітних періодів) і повинна бути погашена, становлячи таким чином належне виконання податкового обов'язку. При цьому слід мати на увазі, що в практичній дійсності можуть виникати ситуації, коли контролюючий орган може з об'єктивних причин не перевіряти декларацію АП до кінця строку, коли платник податку повинен виконати податкове зобов’язання. У цьому разі платник податку повинен виконати свій обов'язок тією мірою, якою він його оцінив, навіть тоді, коли самостійно обчислювана ним сума податкового зобов'язання, зазначена в декларації АП, є помилковою, а платник не помітив цієї помилки. Такий обов'язок міститься в Порядку, затвердженому наказом Мінфіну України від 23 січня 2015 року № 14 і стосується випадків, коли: а) платник податку надіслав контролюючому органу декларацію АП поштою, а відповідне поштове відправлення було втрачене, зіпсоване чи відбулась затримка його вручення (пункти 7 i 8 розділу III зазначеного Порядку); б) контролюючий орган надав платнику податку письмове повідомлення про відмову у прийнятті декларації АП, зважаючи на порушення платником вимог пунктів 48.3 і 48.4 ст. 48 ПК України (п. 14 розділу III вказаного Порядку). Критично аналізуючи вказані ситуації в контексті дослідження об'єкту АПСОПТ, можемо дійти висновку, що виконання платником податку податкового обов'язку у частині погашення його податкового зобов'язання є належно виконаним у разі, коли платник податку повною мірою погасив податкове зобов'язання, яке було: а) визначене контролюючим суб’ єктом в результаті перевірки декларації АП (повноцінне добросовісне виконання зобов'язання); б) визначене ним самим і ще не було перевірено контролюючим органом, однак настали строки для виконання відповідного податкового обов'язку (потенційно добросовісне виконання зобов'язання); в) змінене контролюючим органом (чи платником податку самостійно після подання декларації АП та настання строків для виконання зобов'язання) в результаті виявлення в документі факту недоплати (добросовісне виконання зобов'язання). При цьому слід наголосити на тому, що про добросовісність дій платника податку щодо погашення податкового зобов'язання до моменту, коли сума податкового обов'язку не була змінена контролюючим органом (однак настав строк сплати зобов'язання), можна говорити лише 
до моменту, коли ця сума буде змінена суб'єктом АПСОПТ і не настане строк для виконання платником податку «скорегованого» зобов'язання;

4) діяльності платника податку, що є учасником відносин із приводу АПСОПТ. Окрім того, що суб’єкти АПСОПТ у своїй діяльності спрямовують увагу на звітні документи, порядок їх подання та на погашення платником податку податкових зобов'язань у сфері обігу ПТ, суттєве значення у структурі «комплексного» об’єкта АПСОПТ набуває також контролювання самої діяльності платників податків, спрямоване на перевірку добросовісності дотримання платниками вимог чинного законодавства у їх безпосередній господарській діяльності. Важливість цього об'єкта АПСОПТ підтверджується також логікою законодавця, що прослідковується в Законі України від 30 березня 2020 року № 540-IX, яким підрозділ 10 розділу ХХ ПК України доповнювався п. 52-2, що передбачає встановлення мораторію на проведення документальних та фактичних перевірок на період з 18 березня 2020 року до останнього календарного дня місяця (включно), в якому завершується дія карантину, встановленого КМ України на всій території України з метою запобігання поширенню на території України COVID-19. Встановлюючи такий мораторій, законодавець зазначив, що ним не можуть охоплюватись фактичні перевірки у частині порушення вимог чинного законодавства в частині: а) «обліку, ліцензування, виробництва, зберігання, транспортування та обігу пального, спирту етилового, алкогольних напоїв та тютюнових виробів»; б) «цільового використання пального та спирту етилового платниками податків»; в) «обладнання акцизних складів витратомірами-лічильниками та/або рівномірами-лічильниками»; г) «здійснення функцій, визначених законодавством у сфері виробництва й обігу спирту етилового, алкогольних напоїв та тютюнових виробів, пального» з підстав, передбачених ПК України.

2. Опосередкований об’єкт АПСОПТ, а саме міра (стан) створення належних умов щодо виконання платником податку податкового обов'язку у сфері обігу ПТ:

1) реєстрація особи як платника АП, а саме реєстрація платника податку, внесення змін до відомостей про платника податку та скасування реєстрації. Іншими словами, цей опосередкований об’єкт АПСОПТ відображає динаміку відносин із приводу адміністрування відповідних податків - їх виникнення, зміну та припинення. 3 огляду на те, що суб'єкти АПСОПТ спрямовані у своїй діяльності на створення сприятливих умов для реалізації платниками АП свого податкового обов'язку, цілком закономірним є те, що зазначений опосередкований об'єкт має суттєве значення в діяльності повноважного суб'єкта адміністрації, адже безпосереднім чином позначається на: а) фактичних можливостях фізичних і юридичних осіб реалізувати свої економічні інтереси у сфері обігу ПТ (суттєві бар'єри в цьому можуть бути фактором для розширення «сірого» та «чорного» ринку обігу ПТ); б) збільшенні інвестиційної привабливості України;

2) процеси, пов’язані з організацією та забезпеченням функціонування механізму добросовісного виконання платниками АП податкового обов'язку. Цей опосередкований об'єкт охоплює множину відповідних процесів, зокрема: а) забезпечення контролюючого органу (відповідних підрозділів ДПС України та Держмитслужби України) в належній кількості професійними кадрами, а також належне мотивування їх до ефективного виконання посадових обов'язків, що виявляються в адмініструванні податків у досліджуваній сфері; б) моніторинг здійснення АПСОПТ на предмет недоліків діяльності контролюючих суб'єктів, а також реальних і потенційних ризиків неналежного виконання обов'язків щодо здійснення відповідного адміністрування; в) постійне інформування платників АП актуальними даними про найкращу практику виконання податкового обов'язку та юридичні наслідки неналежного виконання адміністративного та податкового (митного) законодавства у сфері обігу ПТ і т. д.

Висновки. Узагальнюючи викладене, можемо дійти висновку, що АПСОПТ є складним соціально-правовим феноменом, що безпосереднім чином позначається на змісті його об'єкта. Зміст і юридична природа об’єкта АПСОПТ суттєвим чином ускладнюється сучасним, орієнтованим на європейську доктрину адміністративного права розумінням публічного адміністрування. Так, якщо зводити АПСОПТ до «управління процесами виконання податкового обов'язку», то об'єктом цього явища буде формальне справляння податків, що є типовим для держав, які сьогодні не розвиваються в межах парадигми людиноцентризму, на якій грунтуються держави-члени ЄС. Натомість розуміння АПСОПТ як особливого вияву нового концепту публічного адміністрування вимагає досить широкого розуміння цього явища та його об'єкта, який постає комплексною категорією, що відображає практично все, на що повинен спрямовувати увагу суб'єкт АПСОПТ у сучасній демократичній та правовій державі.

\section{Список використаних джерел:}

1. Держак Н.О. Техніка адміністративної діяльності: навчальний посібник. Сєвєродонецьк : СНУ ім. В. Даля, 2019. 144 с.

2. Рачинський Р.М. Доктринальне визначення поняття адміністрування податків і зборів. Актуальні проблеми вітчизняної юриспруденциї. 2017. № 6, Т. 3. С. 148-151.

3. Беспалова А.О. Правове регулювання адміністрування податків і зборів в Україні : дис. ... канд. юрид. наук :12.00.07. Одеса, 2015. 233 с.

4. Паславська Р.Ю. Система адміністрування податків в Україні : дис. ... канд. економ. Наук : 08.00.08. Львів, 2014. 224 с. 
5. Теремецький B.I., Цвірюк Д.В. Територіальні органи Державної фіскальної служби України як суб'єкти адміністрування податків. Вісник Харківського національного університету внутрішніх справ. 2015. № 2. C. 180-189.

6. Савчук В.А. Теоретичні засади організації адміністрування податків. Ефективна економіка. 2013. № 3. URL : http://www.economy.nayka.com.ua/?op=1\&z=1852.

7. Іванишина О.С. Розвиток технологій податкового адміністрування. Вісник Київського національного університету технологій та дизайну. 2012. № 6. С. 288-293.

8. Боксгорн А.В. Теоретичні питання податкового адміністрування та його механізму. Lex portus. 2017. № 3(5). C. 81-91. 
УДК 351.74:342.922

DOI https://doi.org/10.32836/2521-6473.2020-4.5

€. О. Легеза, доктор юридичних наук, профресор, професор кафедри адміністративного та митного права Університету митної справи та фрінансів

\section{ОСОБЛИВОСТІ ЗДІЙСНЕННЯ КОНТРОЛЮ ПІД ЧАС НАДАННЯ ПУБЛІЧНИХ ПОСЛУГ ЗАДЛЯ ЗАПОБІГАННЯ КОРУПЦИИНИМ РИЗИКАМ}

Наукова стаття присвячена удосконаленню контролю з надання публічних послуг задля запобігання корупиійним ризикам. Зокрема, задля створення раціонального механізму контролю під час надання публічних послуг щзодо запобігання корупиії дочільно передбачити в Законі України «Про адміністративні послуги» окрему статтю щзодо особливостей здійснення такого виду контролю. Участь у здійсненні різних видів контролю за належним наданням публічних (адміністративних) послуг задля запобігання корупційним ризикам мають приймати також безпосередньо суб'єкти звернення. Відсутність у технологічних та інформаційних картках певних статей або норм щзодо критерїв контролю та оичнювання якості публічних (адміністративних) послуг позбавляє суб 'єктів звернення зазначених послуг висловити особисту позичію щзодо рівня практичної реалізаиії прав, свобод $і$ законних інтересів спожсивачів. Внаслідок иьього необхідно відповідним чином змінити нормативно-правові акти, зокрема статтю 8 Закону України «Про адміністративні послуги».

На сучасному етапі надання публічних (адміністративних) послуг вкрай необхідна налагоджена система контролю задля запобігання корупиійним ризикам із конструктивно відпрацьованим механізмом ефективної взаємодії суб 'єктів органів публічної адміністрації, координації діяльності на всіх рівнях суб'єктів звернення, щзо є необхідною передумовою трансформаиії українського суспільства на принципах верховенства права, демократії, прав людини та громадянина.

Запропоновано розуміти під контролем надання публічних послуг щзодо запобігання корупиійним ризикам регламентовану законодавством діяльність суб 'єктів публічної адміністраиії (органів державної влади та місиевого самоврядування), громадян чи їх об'єднань щэодо виконання положень нормативно-правових актів відповідними органами влади, належного виконання ними своїх повноважень та дотримання прав, свобод $і$ законних інтересів споживачів.

Ключові слова: адміністративна послуга, відомчий контроль, запобігання корупиії, контроль, корупція, послуга.

Ye. O. Leheza. Features of control during the provision of administrative services in order to prevent corruption risks

The scientific article is devoted to the improvement of control during the provision of administrative services in order to prevent corruption risks. In particular, in order to create a rational control mechanism in the provision of administrative services to prevent corruption, it is advisable to provide in the Law of Ukraine "On Administrative Services" a separate article on the specifics of this type of control. Applicants should also be directly involved in the implementation of various types of control over the proper provision of public (administrative) services in order to prevent corruption risks. The absence of certain articles or norms in the technological and information cards on the criteria of control and evaluation of the quality of public (administrative) services deprives the subjects of these services to express a personal position on the level of practical realization of rights, freedoms and legitimate interests of consumers. As a result, it is necessary to make appropriate changes to regulations, in particular Article 8 of the Law of Ukraine "On Administrative Services", etc.

At the present stage of providing public (administrative) services it is extremely necessary to have a well-established control system to prevent corruption risks with a constructive mechanism for effective interaction of public administration entities, coordination of activities at all levels of appeal, which is a necessary prerequisite principles of the rule of law, democracy, human and civil rights.

It is proposed to understand the control of the provision of administrative services to prevent corruption risks to understand the statutory activities of public administration (public authorities and local governments), citizens or their associations to implement the provisions of regulations by relevant authorities, their proper implementation powers and observance of the rights, freedoms and legitimate interests of consumers.

Key words: administrative service, departmental control, corruption prevention, control, corruption, service.

Постановка проблеми. Усвідомлення нової ролі органів публічної адміністрації в процесі задоволення потреб суб' єктів звернення полягає у забезпеченні останніх якісними публічними (адміністративними) послугами [16]. Між тим наявна система надання таких послуг не завжди чітко розмежовує відповідальність за надання неякісних публічних послуг суб' єктам звернення між різними рівнями публічної влади, не забезпечує своєчасне надання послуг, їх відкритість, прозорість тощо [16]. Така ситуація визначає необхідність удосконалення механізмів надання публічних, в тому числі адміністративних, послуг [16]. Саме контроль спрямовує суспільні відносини на запуск необхідних механізмів досягнення суспільно важливої прогресивної мети надання публічних послуг [16], тому особливо актуальним сьогодні є дослідження правового регу-

(C) С. О. Легеза, 2020 
лювання контролю з надання публічних послуг задля запобігання корупційним ризикам на сучасному етапі здійснення адміністративної реформи, адже в цьому полягає забезпечення зворотного зв'язку діяльності органів публічної адміністрації [1, с. 291-296; 16, с. 223].

Аналіз останніх досліджень і публікацій. Узагальнюючи вітчизняну адміністративно-правову наукову, навчальну, публіцистичну літературу, стверджуємо, що нині виникли два основні напрями дослідження проблематики здійснення функції державного (управлінського) контролю. Перший сформований на початку 90-х pp. і зосереджений на здійсненні контролю як способу забезпечення законності управлінсько-розпорядчої діяльності держави (наприклад, праці таких науковців, як Ю.П. Битяк, В.В. Зуй, В.М. Гаращук [12], Т.О. Коломоєць [13], С.О. Мосьондз [14]). Другий напрям з'явився на початку ХХІ ст. і виходить із розуміння контролю як багатогранного явища та способу забезпечення законності як основної функції та принципу державної діяльності [15].

До контролю за додержанням законодавства з надання публічних послуг органами публічної адміністрації можна застосувати певні класифікаційні підстави, які пропонує Т.О. Коломоєць, проте з урахуванням особливостей контролю, що безпосередньо розглядається таким чином:

- за суб'єктом контролю - державний (з боку державних органів: президентський, парламентський тощо), приватний (громадський), змішаний (спільний);

- за об’єктом - контроль за діяльністю органів державної влади та місцевого самоврядування;

- за предметом контролю - за ініціативою фізичних та юридичних осіб тощо;

- за методом, способом чи формою проведення контролю - інвентаризація, рейд, запит, громадське слухання, ревізія, перевірка тощо;

- за ступенем втручання в об’ єкт контролю - пряме (безпосереднє) або непряме (опосередковане) втручання в оперативну діяльність;

• залежно від стадії контролю - попередній, оперативний (поточний), остаточний (підсумковий);

- залежно від обсягу контролю (за кількістю різновидів діяльності) - повний (за всією діяльністю органів публічної адміністрації щодо надання публічних послуг), вибірковий (щодо окремих видів таких послуг);

- $з$ урахуванням необхідності використання під час контролю спеціальних приладів і спеціальних засобів - контроль за їх допомогою або без їх використання;

- за спрямованістю - з боку інших органів (зовнішній) чи самоконтроль (внутрішній);

- за характером контрольної діяльності - загальний і спеціальний (з окремих питань);

- залежно від мети - щодо з'ясування умов і причин, що сприяли порушенню вимог законодавства, щодо притягнення до відповідальності винних, щодо аналізу якості та ефективності/неефективності діяльності тощо;

- за впливом наслідків проведеного контролю на об'єкт - позитивний, негативний (репресивний);

- за безпосереднім суб'єктом здійснення - місцевими органами виконавчої влади, центральними органами виконавчої влади, правоохоронними органами, судовими органами, територіальною громадою тощо;

• за кількістю суб’єктів контролю - індивідуальний, колективний тощо;

- за сферою підконтрольної діяльності - внутрішній (щодо підконтрольних об'єктів), міжвідомчий (за наявності іншої «відомчої належності»), позавідомчий (за відсутності безпосередньої підпорядкованості між суб' єктами контрольних правовідносин здійснюється суб'єктами, наділеними загальною компетенцією здійснювати контроль);

- за безпосереднім спрямуванням - за законністю чи доцільністю діяльності тощо [13].

Мета статті полягає у визначенні та аналізі особливостей здійснення контролю під час надання публічних послуг для запобігання корупційним ризикам.

Виклад основного матеріалу. Термін «контроль» 3'явився декілька століть тому. Він походить від французького «список, що ведеться в двох екземплярах» [2, с. 360; 3, с. 286; 16]. У статті 1 Лімської декларації керівних принципів контролю зазначено, що контроль взагалі є не самоціллю, а невід'ємною частиною системи регулювання, метою якої є встановлення відхилень від прийнятих стандартів і порушень принципів, законності, ефективності та економії витрачання матеріальних ресурсів на якомога ранній стадії, щоби мати можливість вжити коригуючих заходів, іноді притягти винних до відповідальності, отримати компенсацію за заподіяну шкоду або вжити заходів щодо запобігання або скорочення таких порушень у майбутньому [4]. Мета контролю полягає у встановленні результатів діяльності певних суб'єктів, допущених відхилень від прийнятих вимог, принципів організації, виявленні причин цих відхилень, а також у визначенні шляхів подолання перешкод для ефективного функціонування всієї системи [5, с. 349].

У статті 1 Закону України «Про адміністративні послуги» визначено коло основних суб'єктів відносин у сфері надання публічних послуг: 1) суб'єкт звернення - фізична особа, юридична особа, яка звертається за отриманням публічних послуг; 2) суб'єкт надання адміністративної послуги - орган виконавчої влади, інший державний орган, орган влади Автономної Республіки Крим, орган місцевого самоврядування, їх посадові особи, уповноважені відповідно до закону надавати адміністративні послуги [6]. Відповідно до суб’ єктів, що здійснюють контроль у сфері надання публічних послуг, можна виділити державний контроль, внутрішній контроль та громадський контроль [16]. 
Сутність державного контролю під час надання публічних послуг щодо запобігання корупції виходить із положень статті 19 Закону України «Про адміністративні послуги» [16]. Посадові особи, уповноважені відповідно до закону надавати адміністративні послуги, адміністратори несуть дисциплінарну, цивільну, адміністративну або кримінальну відповідальність, передбачену законом, за порушення вимог законодавства у сфері надання публічних послуг [16]. Дії або бездіяльність посадових осіб, уповноважених відповідно до закону надавати адміністративні послуги, адміністраторів можуть бути оскаржені до суду в порядку, встановленому законом [16]. Шкода, заподіяна фізичним або юридичним особам посадовими особами, уповноваженими відповідно до закону надавати адміністративні послуги, адміністраторами внаслідок їх неправомірних діянь, відшкодовується у встановленому законом порядку. Держава, Автономна Республіка Крим, територіальні громади, відшкодувавши шкоду, заподіяну посадовою особою, уповноваженою відповідно до закону надавати адміністративні послуги, чи адміністратором внаслідок незаконно прийнятих ними рішень, дій чи бездіяльності, мають право зворотної вимоги до винної особи згідно із законом [6].

Держава є одним із головних суб' єктів здійснення контрольної функції в суспільстві, адже вона наділена реальними повноваженнями для впливу на суспільство, під час здійснення якого вона покладається на засоби контролю [16]. Отже, державний контроль є важливим видом діяльності держави, сутність якого полягає у спостереженні та перевірці розвитку суспільної системи та всіх їі елементів відповідно до визначених напрямів, а також у попередженні та виправленні можливих помилок і неправомірних дій, що перешкоджають такому розвитку [5, с. 349; 16].

Державний контроль під час надання публічних послуг щодо запобігання корупції може здійснюватися уповноваженими державними органами, посадовими особами й спрямований на забезпечення законності, дисципліни та дотримання стандартів, норм і правил надання публічних послуг [16]. Як правило, такий контроль здійснюється тим адміністративним органом, до компетенції якого належить те чи інше питання у сфері надання публічних послуг [16].

Підставами для вжиття відповідних заходів контролю під час надання публічних послуг щодо запобігання корупції можуть бути письмове звернення фізичної або юридичної особи про порушення вимог законодавства у сфері надання публічних послуг; письмове звернення або запит адміністративних органів щодо виявлених фактів порушення вимог законодавства у сфері надання публічних послуг [16].

Варто відзначити, що, згідно з частиною 4 статті 13 Закону України «Про адміністративні послуги», одним із основних завдань адміністратора є здійснення контролю за додержанням суб'єктами надання публічних послуг термінів розгляду справ та прийняття рішень [16]. Адміністратор - це посадова особа органу, що утворив центр надання публічних послуг, яка організовує процедури надання публічних послуг шляхом взаємодії із суб'єктами процедури надання публічних послуг [5; 16]. Це завдання адміністратор може реалізувати, зокрема, через фіксування у порядку, передбаченому Примірним регламентом центру процедури надання публічних послуг [8; 16], дати надходження справи; дати передачі справи відповідному суб'єкту надання адміністративної справи або структурним підрозділам суб'єкта надання адміністративної послуги, відповідальним за етапи (дію, рішення); дотримання строків проходження кожного етапу адміністративної послуги [16]; строків розгляду справи відповідним суб'єктом надання адміністративної справи; дати передання результату адміністративної послуги суб' єкту звернення. Висновок про дотримання термінів розгляду справ та прийняття рішень адміністратор може зробити, порівнюючи реальні строки зі строками, визначеними у технологічній картці адміністративної послуги [16].

Урядом України було прийнято Постанову «Деякі питання ведення обліку доходів, які надходять як плата за надання публічних послуг» від 7 серпня 2013 р. № 600, у якій зазначено таке:

1) облік доходів, які надходять як плата за надання публічних послуг, ведеться органами Державної казначейської служби у розрізі головних розпорядників бюджетних коштів згідно з кодами відомчої класифікації видатків та кредитування державного бюджету й територій;

2) бюджетні рахунки для ведення обліку зазначених доходів відкриваються в органах Державної казначейської служби за відомчою ознакою на підставі звернень головних розпорядників бюджетних коштів протягом місяця з дня набуття чинності цією постановою [16]; органи Державної казначейської служби надають виписки з таких рахунків у встановленому законодавством порядку;

3) відображення бюджетними установами операцій з процедури надання публічних послуг у бухгалтерському обліку та розкриття відповідної інформації у розрізі видів публічних послуг здійснюється в порядку, визначеному Міністерством фінансів [16].

Крім цього, Державну казначейську службу зобов'язано щокварталу та щороку подавати органам влади у строки, передбачені для подання звітності про виконання бюджету, інформацію про доходи, які надходять як плата за надання публічних послуг, у розрізі видів публічних послуг і кодів відомчої класифікації видатків та кредитування державного бюджету [9].

Не менш важливою проблемою контролю під час надання публічних послуг щодо запобігання корупції є неврегульованість механізму розподілу та використання коштів, які надходять як плата за такі послуги [16]. Відповідно до частини 1 статті 18 Закону України «Про адміністративні послуги», фінансове та інше забезпечення діяльності системи державних органів, органів влади Автономної Республіки Крим, органів 
місцевого самоврядування з процедури надання публічних послуг здійснюється виключно за рахунок Державного бюджету України, відповідних місцевих бюджетів [16], тобто, ефективність розподілу та використання фінансових ресурсів суб'єктами процедури надання публічних послуг є передумовою для успішного здійснення їхньої діяльності [16].

Неналежне й недостатнє фінансування діяльності органів публічної адміністрації є чинником, що безпосередньо впливає на специфіку надання публічних послуг, зокрема на їх цілісність, якість, платний характер, розміри плати [16]. Нині слід констатувати, що суб'єкти процедури надання публічних послуг через недостатню фінансову підтримку не здатні в повному обсязі виконувати всі повноваження. Як наслідок, це не сприяє реалізації прав, свобод і законних інтересів суб’єктів звернення у сфері надання публічних послуг [16].

Отже, сьогодні потребують законодавчого вирішення такі питання:

1) порядок розподілу коштів, які надходять за адміністративні послуги, між суб’єктами надання таких послуг [16];

2) порядок використання грошових ресурсів, які надходять за адміністративні послуги, на ті цілі, на які вони справлялися [16];

3) здійснення належного фінансового контролю за розподілом та використанням коштів, які надходять за адміністративні послуги [16].

Знову ж таки вважаємо, що це має бути вирішене у системному нормативно-правовому акті, який повинен регламентувати питання плати за процедури надання публічних послуг $[10$, с. $47 ; 16]$.

Висновки 3 дослідження і перспективи подальших розвідок у цьому напрямі. Отже, контроль надання публічних послуг щодо запобігання корупційним ризикам є регламентованою законодавством діяльністю органів влади, тобто суб'єктів публічної адміністрації та суб'єктів звернення щодо виконання положень законодавства України відповідними органами, належного виконання ними своїх повноважень та дотримання прав, свобод і законних інтересів суб’єктів звернення.

\section{Список використаних джерел:}

1. Буханевич О.М. Контроль у сфері надання публічних послуг: сутність та особливості здійснення. Evropsky politicкy a pravni diskurz (Європейський політико-правовий дискурс). 2015. Svazek 2. С. 291-296. $740 \mathrm{c}$.

2. Современный словарь иностранных слов / под ред. Е.А. Гришиной. Москва : Русский язык, 1993.

3. Ожегов С.И., Шведова Н.Ю. Толковый словарь русского языка: 80000 слов и фразеологических выражений. 3-е изд., стереотип. Москва : АЗИ, 1996. 928 с.

4. Лимская декларация руководящих принципов контроля. Контрольно-счетные органы Российской Федерациии (в вопросах и ответах) / под общ. ред. С.В. Степашина. Москва, 2001. 109 с.

5. Адміністративне право України. Академічний курс : підручник : у 2 т. Т. 1 : Загальна частина / ред. колегія: В.Б. Авер'янов (голова). Київ : Юридична думка, 2004. 584 с.

6. Про адміністративні послуги : Закон України від 6 вересня 2012 р. № 5203-VI. Відомості Верховної Ради України. 2013. № 32. Ст. 409.

7. Питання Міністерства економічного розвитку і торгівлі : Постанова Кабінету Міністрів України від 20 серпня 2014 р. № 459. URL. http://zakon2.rada.gov.ua/laws/show/459-2014-п.

8. Про затвердження Примірного регламенту центру надання публічних послуг : Постанова Кабінету Міністрів України від 1 серпня р. № 588. URL: http://zakon4.rada.gov.ua/laws/show/588-2013-п.

9. Деякі питання ведення обліку доходів, які надходять як плата за надання публічних послуг : Постанова Кабінету Міністрів України від 7 серпня 2013 року № 600. URL: http://zakon4.rada.gov.ua/laws/ show/600-2013-n.

10. Оніщик Ю.В., Буханевич О.М. Правове регулювання плати за надання публічних послуг: проблеми теорії та практики. Наукові записки Інституту законодавства Верховної Ради України. 2015. № 3. С. $43-48$.

11. Коліуш О.Л. Удосконалення контролю під час надання публічних послуг з метою запобігання корупції. Visegrad Journal on Human Rights. 2019. Vol. 2. № 4. С. 67-72.

12. Битяк Ю.П., Гаращук В.М., Зуй В.В. Адміністративне право : підручник. Харків : Право, 2010. $624 \mathrm{c}$.

13. Коломоєць Т.О. Контроль за діяльністю органів місцевого самоврядування як суб'єктів адміністративного права України : монографія. Запоріжжя : Запорізький національний університет, 2011. 256 с.

14. Мосьондз С.О. Адміністративне право України (у визначеннях та схемах) : навчальний посібник. Київ : Атіка, 2008. 272 с.

15. Васильєва О.І. Діяльність органів державної влади та органів місцевого самоврядування у сфері надання публічних послуг як об’ єкт контролю. Науковий вісник Академї муніципального управління. Серія: Управління. 2014. Вип. 1. С. 19-28. URL: http://nbuv.gov.ua/UJRN/Nvamu_upravl_2014_1_4.

16. Гончарова I.A. Адміністративно-правовий аспект процедури надання публічних послуг : дис. ... канд. юрид. наук : спец. 12.00.07. Запоріжжя, 2017. 215 с. URL: http://phd.znu.edu.ua/page/dis/07/Honcharova_ diss.pdf. 
УДК 342.9(477)

DOI https://doi.org/10.32836/2521-6473.2020-4.6

\author{
Р. В. Мазурик, кандидат юридичних наук, \\ здобувач наукового ступеня доктора юридичних наук \\ Університету митної справи та фрінансів
}

\title{
РЕАЛІЗАЦІЯ АНТИКОРУПЦІЙНОЇ СТРАТЕГІЇ НА 2020-2024 РОКИ В ДІЯЛЬНОСТІ ОРГАНІВ ПРОКУРАТУРИ
}

У науковій публікації досліджено актуальні питання реалізації Антикорупиійної стратегії на 2020-2024 роки в діяльності органів прокуратури. Зазначено, щз запобігання корупиії в діяльності прокуратури та інших органів кримінальної юстииії є першочерговим завданням публічної адміністращії. Зазначено, щь від професіоналізму, неупередженості та непідкупності прокурорів залежить рівень довіри громадян до органів прокуратури. Так, згідно з останнім дослідженням Центру Разумкова, прокуратурі не довіряють 70\% громадян України, щз свідчить про низьку ефективність проведених реформ та потребу суттєвого удосконалення правових засад організації та діяльності прокуратури, особливо щчодо запобігання та протидії корупиіï.

Методологія дослідження спирається на органічне поєднання філософських, загальнонаукових та спечіально-юридичних методів дослідження, серед яких ключову роль відіграють закони філософського методу діалектики (єдності та боротьби протилежностей, переходу кількісних змін у якісні), а також прийом «заперечення заперечення». Серед загальнонаукових методів дослідження застосовуються прийоми логічного методу (аналіз, синтез, дедукиія та індукиія), системний та структурно-функиіональний методи, прийоми соиіологічного методу тошо. Зі спечіально-юридичних методів дослідження використовуються методи юридичної логіки та юридичної статистики, метод юридичноі догматики (як різновид аксіоматичного методу) та метод юридичного моделювання.

До інноваиійних способів запобігання та протидії корупиії в органах прокуратури запропоновано віднести запровадження електронної системи управління персоналом, яка буде включати автоматизовану систему розподілу справ між прокурорами з урахуванням спещіалізащії та досвіду роботи; розроблення в рамках електронної системи управління персоналом прозорої та дієвої системи оијнювання якості роботи прокурорів, з огляду на результати якої будуть прийматися кадрові та управлінські рішення, а також рішення про преміювання прокурорів; реалізацію конщепиї «прозорого офісу» з використанням систем відеоспостереження; затвердження наказом Генерального прокурора нового порядку проведення таємної перевірки доброчесності прокурорів на виконання ч. $5 \mathrm{~cm} .19$ Закону України «Про прокуратуру» (новий порядок має включати не тільки перевірку анкети доброчесності прокурора, але й альтернативні способи таємної перевірки доброчесності); прийняття окремого наказу Генерального прокурора, яким буде затверджений механізм забезпечення запобігання та протидії корупиї як поза межсами кримінальних проваджень, так $і$ в самій системі органів прокуратури (на виконання перспективної Антикорупиійної програми Офісу Генерального прокурора на 2021-2022 роки).

Сформовано висновок щзодо перспективності подальшого дослідження иієї тематики з огляду на необхідність внесення змін до чинного національного законодавства щзодо впровадження нових способів запобігання корупиії в діяльності прокуратури та інших органів кримінальної юстииіі.

Ключові слова: антикорупиійна стратегія, корупиія, запобігання, законодавство, обласна прокуратура, адміністративно-правові засади, удосконалення, функиії, способи.

\section{R. V. Mazuryk. The implementation of the Anti-Corruption Strategy for 2020-2024 in the activities of the prosecutor's} office

The scientific publication is devoted to the current issues of implementation of the Anti-Corruption Strategy for 2020-2024 in the activities of the prosecutor's office. It is noted that preventing corruption in the activities of the prosecutor's office and other criminal justice bodies is a priority of the public administration. It is noted that the level of public confidence in the prosecutor's office depends on the professionalism, impartiality and incorruptibility of prosecutors. Thus, according to a recent study by the Razumkov Center, $70 \%$ of Ukrainian citizens do not trust the prosecutor's office, which indicates the low effectiveness of reforms and the need to significantly improve the legal framework of the prosecutor's office, especially in preventing and combating corruption.

The methodology of this study is based on an organic combination of philosophical, general and special legal research methods, among which the key role is played by the laws of the philosophical method of dialectics (unity and struggle of opposites, the transition from quantitative to qualitative). Among the general scientific research methods, the methods of the logical method (analysis, synthesis, deduction and induction), systemic and structural-functional methods, methods of the sociological method, etc. are used. The methods of legal logic and legal statistics, the method of legal dogmatic (as a kind of axiomatic method) and the method of legal modeling are used as special legal research methods.

Innovative ways to prevent and combat corruption in the prosecutor's office include: introduction of an electronic personnel management system, which will include an automated system for the distribution of cases between prosecutors, taking into account specialization and experience; development within the framework of the electronic personnel management system

(C) Р. В. Мазурик, 2020 
of a transparent and effective system for assessing the quality of prosecutors' work, based on the results of which personnel and management decisions will be made, as well as decisions on awarding prosecutors; implementation of the concept of «transparent office» using video surveillance systems; approval by the order of the Prosecutor General of a new procedure for conducting a secret inspection of the integrity of prosecutors in pursuance of Part 5 of Art. 19 of the Law of Ukraine "On the Prosecutor's Office" (the new procedure should include not only the verification of the integrity questionnaire of the prosecutor, but also alternative methods of secret integrity check); adoption of the order of the Prosecutor General, which will approve the mechanism for preventing and combating corruption both outside criminal proceedings and in the system of prosecutors (to implement the promising anti-corruption program of the Office of the Prosecutor General for 2021-2022).

The conclusion on the prospects of further research on this topic is formulated, taking into account the need to amend the current national legislation on the introduction of new ways to prevent corruption in the prosecution and other criminal justice authorities.

Key words: anti-corruption strategy, corruption, prevention, legislation, regional prosecutor's office, administrative and legal principles, improvements, functions, means.

Постановка проблеми. Корупція в органах кримінальної юстиції є найбільш загрозливим явищем для держави та суспільства, адже кожен суб'єкт владних повноважень є представником держави і навіть поодинокі факти корупції серед правоохоронців викликають великий суспільний резонанс та знижують рівень поваги до публічної адміністрації загалом.

Результати соціологічних досліджень засвідчують, що частка громадян, які мають безпосередній досвід корупції, протягом останніх років суттєво зменшилась (якщо у 2013 році такий досвід мало близько 60\%, то станом на початок 2020 року - не більше 40\% громадян). Спостерігається також поступове покращення порівняльних показників рівня корупції в Україні. Згідно з даними міжнародної організації "Transparency International”, у період з 2013 по 2019 роки Індекс сприйняття корупції в Україні зріс із 25 до 30 балів. Однак результати цих досліджень свідчать про те, що досягнутий за останні роки прогрес не задовольняє суспільство, оскільки є надто повільним. Загальний рівень сприйняття корупції в Україні залишається високим (у 2019 році, набравши 30 балів зі 100 можливих, Україна за Індексом сприйняття корупції посіла 126 місце серед 180 країн). Корупція, як і раніше, залишається однією з найважливіших проблем (згідно з опитуванням, проведеним на початку 2020 року, важливість проблеми корупції залишається на одному рівні 3 питанням вирішення кризи на Донбасі). Низькі темпи реалізації антикорупційної політики в Україні суттєво сповільнюють їі економічне зростання [1].

Рівень корупції в системі органів публічної адміністрації прямо впливає на оцінку громадянами ефективності державної політики та правозастосування у різних сферах суспільних відносин. Показовим у цьому аспекті є рівень довіри громадян до основних державних інституцій. Згідно з останнім соціологічним дослідженням Центру Разумкова, недовіра частіше висловлюється державному апарату (чиновникам) (не довіряють їм 79\% опитаних), ЗМІ Росії (79\%), Верховній Раді України (76\%), судам (судовій системі загалом) (75\%), Уряду України (75\%), політичним партіям (73\%), комерційним банкам (73\%), Національному антикорупційному бюро України (НАБУ) (72,5\%), Національному агентству з питань запобігання корупції (НАЗК) (71\%), Спеціалізованій антикорупційній прокуратурі (70\%), Вищому антикорупційному суду (70\%), Прокуратурі (70\%), Конституційному Суду України (65\%), Національному банку України (64\%), місцевим судам (63\%), Верховному Суду (63\%), Президенту України (60\%), профспілкам (54\%), Національній поліції $(53 \%)$, Службі Безпеки України (51\%) [2]. Таким чином, рівень довіри до органів прокуратури є критично низьким, що обумовлює необхідність наукового пошуку основних напрямів та способів удосконалення правових засад організації та діяльності прокуратури, включаючи розроблення інноваційних способів запобігання корупції. Результатом такої наукової роботи мають стати пропозиції щодо перспективних напрямів удосконалення чинного законодавства у сфері запобігання корупції. Вищевикладеним обгрунтовується як теоретичне, так і практичне значення підготовки публікації.

Методологія дослідження спирається на органічне поєднання філософських, загальнонаукових та спеціально-юридичних методів дослідження, серед яких ключову роль відіграють закони філософського методу діалектики (єдності та боротьби протилежностей, переходу кількісних змін у якісні), а також прийом «заперечення заперечення». Серед загальнонаукових методів дослідження застосовуються прийоми логічного методу (аналіз, синтез, дедукція та індукція), системний та структурно-функціональний методи, прийоми соціологічного методу тощо. Зі спеціально-юридичних методів дослідження використовуються методи юридичної логіки та юридичної статистики, метод юридичної догматики (як різновид аксіоматичного методу) та метод юридичного моделювання.

Аналіз останніх досліджень і публікацій. Питання адміністративно-правового забезпечення діяльності правоохоронних органів досліджуються в роботах фахівців у сфері адміністративного права, серед яких слід назвати роботи О. Бандурки, В. Бевзенка, М. Віхляєва, Н. Губерської, С. Гусарова, Р. Калюжного, Т. Коломоєць, В. Колпакова, А. Комзюка, О. Кузьменко, В. Курила, Д. Лук’янця, Д. Лученка, П. Лютікова, Р. Мельника, О. Миколенка, Н. Нижник, Д. Приймаченка, Ю. Севрука, С. Стеценка, М. Тищенка, А. Школика та інших учених-адміністративістів. 
Актуальні питання адміністративно-правового забезпечення організації та діяльності органів прокуратури досліджували у своїх працях такі відомі науковці, як О. Агєєв («Прокурор як суб’єкт адміністративного процесу» [3]), М. Івчук («Адміністративно-правовий статус органів прокуратури України» [4]), О. Іщук («Адміністративна юрисдикція органів прокуратури» [5]), С. Кулинич («Управлінські процедури в діяльності органів прокуратури України» [6]), В. Миколенко («Прокуратура України як суб’ єкт адміністративного права» [7]), Є. Попович («Управління органами прокуратури України: організаційно-правові проблеми» [8]), В. Сухонос («Прокуратура в механізмі української держави: проблеми теорії та практики» [9]), В. Шуба («Адміністративно-правові відносини в діяльності органів прокуратури України» [10]), М. Якимчук («Організаційно-правові основи управління в органах прокуратури України» [11]).

Із останніх досліджень слід відзначити роботи Ю. Чаплинської «Адміністративно-правове забезпечення реформування органів прокуратури України» [12], П. Шаганенко «Адміністративно-правове регулювання організаційного забезпечення діяльності органів прокуратури» [13], С. Циганка «Поняття і зміст адміністративно-правового забезпечення діяльності прокуратури України» [14], О. Баганця «Адміністративно-правове забезпечення реформи органів прокуратури України» [15], В. Карпунцова «Процесуальна компетенція органів прокуратури України: адміністративно-правовий аспект» [16].

Із останніх досліджень питань запобігання корупції в органах прокуратури слід відзначити роботу М. Іванця «Деякі питання запобігання корупції в органах прокуратури України» [17].

Проте питання реалізації Антикорупційної стратегії на 2020-2024 роки в діяльності органів прокуратури ще не було предметом окремого дослідження, що актуалізує необхідність доктринального аналізу зазначеної теми.

Мета статті полягає у дослідженні теоретичних та практичних аспектів реалізації Антикорупційної стратегії на 2020-2024 роки в діяльності органів прокуратури.

Виклад основного матеріалу. Основним програмним документом, на основі якого приймаються антикорупційні програми органів публічної адміністрації, є Антикорупційна стратегія, яка розробляється Національним агентством 3 питань запобігання корупції за результатами громадських обговорень. Нині на сайті агентства представлено проєкт Антикорупційної стратегії на 2020-2024 роки. Метою Антикорупційної стратегії названо досягнення суттєвого прогресу у запобіганні та протидії корупції, а також забезпечення злагодженості та системності антикорупційної діяльності усіх органів державної влади та органів місцевого самоврядування.

Попередня антикорупційна стратегія зосереджувалась на пріоритетах, пов’язаних зі створенням системи сучасних антикорупційних інструментів (правових інститутів), та розбудові системи антикорупційних органів, що мали забезпечити ефективну реалізацію цих інструментів. Водночас завдяки реалізації інших програмних документів Урядом звужувалися можливості для корупції в окремих секторах через проведення галузевих реформ.

Визначення пріоритетних сфер у запобіганні та протидії корупції на 2020-2024 роки (розділ III) відбулося $з$ огляду на підсумки стандартного опитування щодо рівня корупції в Україні, проведеного у 2020 році (яке включало опитування підприємців, експертів та населення загалом), інших досліджень щодо стану, динаміки та поширеності корупції в Україні, а також за результатами аналізу ефективності реалізації антикорупційної політики. Так, згідно з даними стандартного опитування щодо рівня корупції, найбільш пріоритетним напрямом боротьби з корупцією і для бізнесу (57\% респондентів), і для населення України (52\% респондентів) є очищення від корупції судової системи. Для населення України наступними за пріоритетністю (у порядку спадання) є охорона здоров’я (38\%), поліція і прокуратура (37\%), державний сектор економіки (27\%), податкова і митна сфери (25\%), а також фінансування партій та передвиборчих кампаній (21\%). На думку представників бізнесу, найбільш пріоритетними напрямами у протидії корупції є поліція і прокуратура (41\%), податкова і митна сфери (32\%), фінансування партій та передвиборчих кампаній (25\%), охорона здоров'я (24\%), оборона і безпека (23\%). Схожими за змістом є оцінки бізнесу та експертів щодо найбільш корумпованих сфер на поточний момент. Ними є митниця, земельні відносини, містобудування, будівництво великих інфраструктурних об'єктів, судочинство [1].

Результати аналізу стану корупції в Україні, ефективності антикорупційної політики попередніх періодів, міжнародних стандартів та найкращих світових практик у сфері запобігання та протидії корупції дали змогу сформулювати такі основні засади антикорупційної політики на 2020-2024 роки:

- оптимізація функцій держави та місцевого самоврядування, реалізація якого передусім передбачає усунення дублювання повноважень різними органами; тимчасове припинення реалізації малоефективних повноважень, які характеризуються високим рівнем корупційних ризиків; усунення випадків реалізації одним і тим же органом повноважень, поєднання яких створює додаткові корупційні ризики;

- цифрова трансформація реалізації повноважень органами державної влади та місцевого самоврядування, прозорість діяльності та відкриття даних як основа для мінімізації корупційних ризиків у їх діяльності;

- створення на противагу наявним корупційним практикам більш зручних та законних способів задоволення потреб фізичних і юридичних осіб; 
- забезпечення невідворотності юридичної відповідальності за корупційні та пов’язані $з$ корупцією правопорушення, що створює додатковий стримувальний ефект для всіх суб'єктів правовідносин;

- формування суспільної нетерпимості до корупції, утвердження культури доброчесності та поваги до верховенства права [1].

Антикорупційна стратегія реалізується шляхом виконання відповідної державної антикорупційної програми, яку розробляє Національне агентство з питань запобігання корупції з урахуванням особливостей, установлених Законом України «Про запобігання корупції», та затверджує Кабінет Міністрів України на термін дії Антикорупційної стратегії. На підставі державної антикорупційної програми органи публічної адміністрації розробляють та затверджують власні антикорупційні програми. Так, антикорупційна програма Генеральної прокуратури України на 2019-2020 роки затверджена Наказом Генеральної прокуратури України від 1 березня 2019 року № 38. В ній, зокрема, зазначено, що аналізом повноважень прокурора під час здійснення функцій, передбачених Конституцією України, визнано, що їх більшість є владними та одночасно дискреційними, що створює можливості виникнення корупційних ризиків. Водночас існує низка заходів щодо їх недопущення. У таких випадках скоєння корупційних або пов'язаних з корупцією правопорушень працівниками органів прокуратури України обумовлено перш за все порушенням ними вимог закону. Керівництво органів прокуратури України вживає заходів щодо недопущення таких порушень. Мінімізація їх вчинення досягається шляхом підвищення рівня свідомості працівника щодо несприйняття корупції, вжиття додаткових заходів профілактичного, навчального, методичного та дисциплінарного характеру. Крім того, підвищення фахового рівня, належне матеріально-побутове забезпечення та соціальний захист працівників органів прокуратури України також є дієвими чинниками запобігання корупції [18].

Аналіз антикорупційної програми Генеральної прокуратури України на 2019-2020 роки дає підстави зробити висновок, що іiі положення мають більшою мірою декларативний характер та не містять дієвої системи правових засобів запобігання корупції в органах прокуратури.

У пп. 3.1.5 Антикорупційної стратегії на 2020-2024 роки визначено таку проблему у сфері запобігання корупції в діяльності прокуратури: внутрішні управлінські процеси в органах прокуратури не завжди є прозорими та ефективними. Очікуваними стратегічними результатами є запровадження електронної системи управління персоналом, прозорої та дієвої системи оцінки якості роботи прокурорів, з огляду на результати якої приймаються кадрові та управлінські рішення, а також рішення про преміювання; внесення змін до Закону України «Про прокуратуру», які визначають вичерпний перелік підстав для звільнення та припинення повноважень прокурорів, в тому числі Генерального прокурора, що унеможливлює їх невмотивоване застосування; удосконалення діяльності дисциплінарного органу, що забезпечує своєчасний та об’ єктивний розгляд дисциплінарних скарг щодо прокурорів [1].

Таким чином, пріоритетним та інноваційним способом запобігання корупції в органах прокуратури $\epsilon$ запровадження електронної системи управління персоналом, включаючи прозору та дієву систему оцінки якості роботи прокурорів, з огляду на результати якої будуть прийматися кадрові та управлінські рішення, а також рішення про преміювання прокурорів.

Основні напрями запобігання корупції в діяльності обласних прокуратур повинні узгоджуватися 3 положеннями Стратегії розвитку прокуратури на 2021-2023 роки, затвердженої Наказом Генерального прокурора від 16 жовтня 2020 року № 489. Зокрема, пп. 2.1.2 зазначеної Стратегії передбачає удосконалення методів і заходів забезпечення високого рівня якості реалізації конституційних функцій прокуратури. Серед іншого передбачено таке:

- використання новітніх технологій задля оптимізації системи документообігу, поступової мінімізації паперового документообігу (інтеграція інформаційних електронних систем, впроваджених у роботу органів прокуратури, в єдину систему; розроблення та впровадження системи електронного управління кримінальним провадженням; автоматизація обміну даними з іншими системами та базами даних; поетапна інтеграція системи електронного управління кримінальним провадженням у роботу всіх органів досудового розслідування та суду в усіх регіонах України);

- впровадження системи автоматизованого розподілу кримінальних проваджень серед прокурорів з урахуванням установлених чітких об’єктивних критеріїв (включно з критерієм спеціалізації) разом з гарантіями захисту від можливого зловживання;

- розроблення та впровадження єдиних стандартів роботи прокурора, зокрема стандартів досудового розслідування, а також впровадження вивчення затверджених стандартів у навчальні програми первинної, спеціальної підготовки, підвищення кваліфікації прокурорів в інші навчальні програми; зосередження уваги на розвитку лідерських компетентностей прокурорів;

- удосконалення структури та внутрішнього адміністрування прокуратури, раціональний розподіл кадрів і ресурсів відповідно до конституційних функцій прокуратури; оптимізація чисельності та збалансування співвідношення прокурорів і державних службовців, удосконалення розподілу кримінальних проваджень і робочих процесів; інституційне та операційне вдосконалення діяльності з урахуванням спеціалізацій у межах виконання основних функцій прокуратури; акумулювання людського капіталу та інституційних ресурсів відповідно до пріоритетів, визначених кримінально-правовою політикою; 
- ефективна взаємодія у межах міжнародного співробітництва з урядами та компетентними органами інших держав, міжнародними інституціями; підвищення якості надання міжнародної правової допомоги [19].

Таким чином, у процесі розроблення нових способів запобігання корупції в діяльності органів прокуратури необхідно враховувати вищевикладені положення Стратегії розвитку прокуратури на 2021-2023 роки.

Серед відомчих нормативно-правових актів, які регламентують питання запобігання корупції, слід відзначити Наказ Генеральної прокуратури України «Про розмежування повноважень прокурорів у сфері запобігання та протидії корупції поза межами кримінального провадження» від 13 липня 2018 року № 135. Так, згідно з цим Наказом, керівникам прокуратур усіх рівнів наказано забезпечити належну організацію діяльності у сфері запобігання та протидії корупції поза межами кримінального провадження відповідно до вимог Конституції України, КУПАП, Законів України «Про прокуратуру», «Про запобігання корупції», інших законодавчих актів, а саме у межах наданих законом повноважень вживати заходів щодо притягнення осіб до відповідальності за вчинення корупційних або пов’язаних з корупцією правопорушень, виявлення причин та умов, що сприяли їх вчиненню, а також невиконанню вимог Закону України «Про запобігання корупції» в інший спосіб, відшкодування збитків, шкоди, завданих державі внаслідок скоєння таких правопорушень. Крім того, зазначеним Наказом передбачено обов'язкову участь прокурорів у розгляді судами справ про адміністративні правопорушення, пов'язані з корупцією, передбачені статтями $172^{4}-172^{9}, 172^{9-2}$ КУПАП [20].

Отже, Наказ Генеральної прокуратури України «Про розмежування повноважень прокурорів у сфері запобігання та протидії корупції поза межами кримінального провадження» від 13 липня 2018 року № 135 має суто технічний характер та врегульовує вузьке питання розмежування повноважень прокурорів різних рівнів щодо організації діяльності у сфері запобігання та протидії корупції. Проте нині з огляду на важливість та першочерговість завдань щодо запобігання та протидії корупції в діяльності органів прокуратури $\epsilon$ нагальна потреба розроблення та прийняття окремого наказу Генерального прокурора, яким буде затверджений механізм забезпечення запобігання та протидії корупції як поза межами кримінальних проваджень, так і в самій системі органів прокуратури.

З урахуванням вищевикладеного до інноваційних способів запобігання та протидії корупції в органах прокуратури запропоновано віднести такі:

- запровадження електронної системи управління персоналом, яка буде включати автоматизовану систему розподілу справ між прокурорами з урахуванням спеціалізації та досвіду роботи;

- розроблення в рамках електронної системи управління персоналом прозорої та дієвої системи оцінки якості роботи прокурорів, з огляду на результати якої будуть прийматися кадрові та управлінські рішення, а також рішення про преміювання прокурорів;

- реалізація концепції «прозорого офісу» з використанням систем відеоспостереження;

- затвердження наказом Генерального прокурора нового порядку проведення таємної перевірки доброчесності прокурорів на виконання ч. 5 ст. 19 Закону України «Про прокуратуру» (новий порядок має включати не тільки перевірку анкети доброчесності прокурора, але й альтернативні способи таємної перевірки доброчесності);

- прийняття окремого наказу Генерального прокурора, яким буде затверджений механізм забезпечення запобігання та протидії корупції як поза межами кримінальних проваджень, так і в самій системі органів прокуратури (на виконання перспективної Антикорупційної програми Офісу Генерального прокурора на 2021-2022 роки).

Наведений перелік інноваційних способів запобігання та протидії корупції в органах прокуратури не $є$ вичерпним, що обумовлює необхідність подальшого дослідження цієї тематики задля формулювання конкретних пропозицій щодо внесення змін до чинного національного законодавства у сфері запобігання корупції.

Висновки з дослідження і перспективи подальших розвідок у цьому напрямі. Проведене дослідження теоретичних та практичних аспектів реалізації Антикорупційної стратегії на 2020-2024 роки в діяльності органів прокуратури дає змогу сформулювати висновок про те, що в процесі розроблення нових способів запобігання корупції в діяльності органів прокуратури необхідно враховувати ключові положення Стратегії розвитку прокуратури на 2021-2023 роки.

До інноваційних способів запобігання та протидії корупції в органах прокуратури запропоновано віднести запровадження електронної системи управління персоналом, яка буде включати автоматизовану систему розподілу справ між прокурорами з урахуванням спеціалізації та досвіду роботи; розроблення в рамках електронної системи управління персоналом прозорої та дієвої системи оцінки якості роботи прокурорів, з огляду на результати якої будуть прийматися кадрові та управлінські рішення, а також рішення про преміювання прокурорів; реалізацію концепції «прозорого офісу» 3 використанням систем відеоспостереження; затвердження наказом Генерального прокурора нового порядку проведення таємної перевірки доброчесності прокурорів на виконання ч. 5 ст. 19 Закону України «Про прокуратуру» (новий порядок має включати не тільки перевірку анкети доброчесності прокурора, але й альтернативні способи таємної пере- 
вірки доброчесності); прийняття окремого наказу Генерального прокурора, яким буде затверджений механізм забезпечення запобігання та протидії корупції як поза межами кримінальних проваджень, так і в самій системі органів прокуратури (на виконання перспективної Антикорупційної програми Офісу Генерального прокурора на 2021-2022 роки).

Перспективність подальшого наукового аналізу цієї тематики обумовлена необхідністю розроблення конкретних пропозицій щодо внесення змін до чинного національного законодавства у сфері запобігання корупції, Закону України «Про прокуратуру» та відомчих нормативно-правових актів.

\section{Список використаних джерел:}

1. Проєкт Антикорупційної стратегії на 2020-2024 роки / Національне агентство з питань запобігання корупції : офіційний веб-сайт. Дата оновлення: 11 листопада 2020 p. URL: https://nazk.gov.ua/uk/departamentkoordynatsiyi-antykoruptsijnoyi-polityky/antykoruptsijna-strategiya.

2. Оцінка громадянами ситуації в країні, рівень довіри до соціальних інститутів та політиків, електоральні орієнтації громадян (жовтень-листопад 2020 р.) / Центр Разумкова : офіційний веб-сайт. Дата оновлення: 10 листопада 2020 p. URL: https://razumkov.org.ua/napriamky/sotsiologichni-doslidzhennia/otsinkagromadianamy-sytuatsii-v-kraini-riven-doviry-do-sotsialnykh-instytutiv-ta-politykiv-elektoralni-oriientatsiigromadian-zhovten-lystopad-2020r?fbclid=IwAR1ekEEuud3OUkDtUerFWVPzys3RZPJIqWmVPhqqYc5gYT6p jZkPgHd4m-o.

3. Агєєв О. Прокурор як суб’єкт адміністративного процесу : автореф. дис. ... канд. юрид. наук : спец. 12.00.07 «Адміністративне право і процес; фінансове право; інформаційне право» ; Харківський національний університет внутрішніх справ. Харків, 2006. 18 с.

4. Івчук М. Адміністративно-правовий статус органів прокуратури України : автореф. дис. ... канд. юрид. наук : спец. 12.00.07 «Адміністративне право і процес; фінансове право; інформаційне право» ; Державний науково-дослідний інститут МВС України. Київ, 2011. 19 с.

5. Іщук О. Адміністративна юрисдикція органів прокуратури : автореф. дис. ... канд. юрид. наук : спец. 12.00.07 «Адміністративне право і процес; фінансове право; інформаційне право» ; МВС України, Харківський національний університет внутрішніх справ. Харків, 2011. 19 с.

6. Кулинич С. Управлінські процедури в діяльності органів прокуратури України : автореф. дис. ... канд. юрид. наук : спец. 12.00.07 «Адміністративне право і процес; фінансове право; інформаційне право» ; МВС України, Харківський національний університет внутрішніх справ. Харків, 2007. 21 с.

7. Миколенко В. Прокуратура України як суб’єкт адміністративного права : автореф. дис. ... канд. юрид. наук : спец. 12.00.07 «Адміністративне право і процес; фінансове право; інформаційне право» ; Міжрегіональна академія управління персоналом. Київ, 2011. 19 с.

8. Попович Є. Управління органами прокуратури України: організаційно-правові проблеми : автореф. дис. ... докт. юрид. наук : спец. 12.00.07 «Адміністративне право і процес; фінансове право; інформаційне право» ; Харківський національний університет внутрішніх справ. Харків, 2010. 32 с.

9. Сухонос В. Прокуратура в механізмі української держави: проблеми теорії та практики : автореф. дис. ... докт. юрид. наук : спец. 12.00.10 «Судоустрій; прокуратура та адвокатура»; Одеська національна юридична академія». Одеса, 2009. 35 c. URL: https://core.ac.uk/download/pdf/50595502.pdf.

10. Шуба В. Адміністративно-правові відносини в діяльності органів прокуратури України: загальнотеоретичні аспекти : автореф. дис. ... канд. юрид. наук : спец. 12.00.07 «Адміністративне право і процес; фінансове право; інформаційне право» ; Національна юридична академія України ім. Я. Мудрого. Харків, 2007. $20 \mathrm{c}$.

11. Якимчук М. Організаційно-правові основи управління в органах прокуратури України : автореф. дис. ... докт. юрид. наук : спец. 12.00.07 «Адміністративне право і процес; фінансове право; інформаційне право» ; Інститут держави і права ім. В.М. Корецького НАН України. Київ, 2002. 32 с.

12. Чаплинська Ю. Адміністративно-правове забезпечення реформування органів прокуратури України : автореф. дис. ... докт. юрид. наук : спец. 12.00.07 «Адміністративне право і процес; фінансове право; інформаційне право» ; Міністерство внутрішніх справ України, Харківський національний університет внутрішніх справ. Харків, 2018. 42 с.

13. Шаганенко П. Адміністративно-правове регулювання організаційного забезпечення діяльності органів прокуратури. Visegrad Journal on Human Rights. 2015. № 5/1. C. 138-143.

14. Циганок С. Поняття і зміст адміністративно-правового забезпечення діяльності прокуратури України. Підприємництво, господарство і право. 2018. № 11. С. 135-139.

15. Баганець О. Адміністративно-правове забезпечення реформи органів прокуратури України: автореф. дис. ... канд. юрид. наук : спец. 12.00.07 «Адміністративне право і процес; фінансове право; інформаційне право» ; ПрАТ Вищий навчальний заклад «Міжрегіональна академія управління персоналом». Київ, 2019. $16 \mathrm{c}$.

16. Карпунцов В. Процесуальна компетенція органів прокуратури України: адміністративно-правовий аспект : автореф. дис. ... докт. юрид. наук : спец. 12.00.07 «Адміністративне право і процес; фінансове право; 
інформаційне право» ; Державний науково-дослідний інститут Міністерства внутрішніх справ України. Київ, 2018. 36 с.

17. Іванець М. Деякі питання запобігання корупції в органах прокуратури України. Право.иа. 2017. № 3. С. 206-209.

18. Про затвердження антикорупційної програми Генеральної прокуратури України на 2019-2020 роки : Наказ ГПУ від 1 березня 2019 p. №38. URL: https://www.gp.gov.ua/ua/iord?_m=publications\&_t=rec\&id=242880.

19. Стратегія розвитку прокуратури на 2021-2023 роки, затверджена Наказом Генерального прокурора від 16 жовтня 2020 р. № 489. URL: https://www.gp.gov.ua/ua/iord?_m=publications\&_t=rec\&id=262782.

20. Про розмежування повноважень прокурорів у сфері запобігання та протидії корупції поза межами кримінального провадження : Наказ Генеральної прокуратури України від 13 липня 2018 р. № 135. URL: https://www.gp.gov.ua/ua/gn. 
УДК 342.9.23:351.746

DOI https://doi.org/10.32836/2521-6473.2020-4.7

\author{
О. П. Махмурова-Дишлюк, кандидат юридичних наук, \\ докторант Науково-дослідного інституту публічного права
}

\title{
ПРАВА І СВОБОДИ ЛЮДИНИ ТА ГРОМАДЯНИНА В УМОВАХ ЗБРОЙНОГО КОНФЛІКТУ В УКРАЇНІ ЯК ОБ'ЄКТ АДМІНІСТРАТИВНО-ПРАВОВОГО ЗАБЕЗПЕЧЕННЯ
}

У статті наголошено на тому, що в теорії адміністративного права об'єкт здебільшого розглядається як елемент формального складу адміністративно-правових відносин. Як вважають провідні вчені-адміністративісти, об'єктом адміністративно-правових відносин є те матеріальне або нематеріальне благо, на використання чи охорону якого спрямовано суб 'єктивні права та юридчні обов'язки учасників адміністративно-правових відносин. Це блага матеріальні або нематеріальні, а також певні дії, заради яких суб'єкти вступають в адміністративно-правові відносини. Права людини й громадянина є об'єктом адміністративного права, оскільки вони є природними та (або) закріплені в Конституиії, інших законах України та міжнародних основоположних нормативно-правових актах, які ратифіковані Верховної Радою України. Згідно з ичим, незаперечним правом будь якої особи, щзо перебуває під юрисдикиією України, є право на життя $і$ здоров'я. Визначено, щзо Міжнародне гуманітарне право не містить заборони на ведення війни, ияю заборону містять інші норми міжнародного права. Міжнародне гуманітарне право застосовується лише в разі збройного конфлікту та створено державами саме для того, щоб накласти певні рамки на насильство під час війни, обмежити страждання, захистити жертв війни. З'ясовано, що Міжнародне гуманітарне право не забороняє застосовувати зброю задля виведення комбатантів зі строю шляхом вбивства, поранення чи нанесення важких психологічних травм у бою. Комбати будь-якої сторони конфлікту мають право безпосередньо брати участь у військових діях. Міжнародне гуманітарне право забороняє застосування військової сили щзодо не комбатантів та ичиільних осіб. Зроблено висновок, щзо права і свободи людини та громадянина в умовах збройних конфліктів в Україні як об’єкт адміністративно-правового забезпечення - ие нематеріальні (життя, здоров'я, честь, гідність тощо) та матеріальні (харчування, житло, одяг, фінанси тощо) иінності, які, відповідно до наданої компетениії, в процесі надання адміністративних послуг та виконавчої діяльності надаються суб 'єктами публічної адміністрації особам, щзо постраждали внаслідок збройного конфлікту.

Ключові слова: адміністративні послуги, адміністративно-правове забезпечення, виконавча діяльність, збройний конфлікт, компетениія, нематеріальні ичінності, права і свободи людини.

O. P. Makhmurova-Dyshliuk. Human and citizen's rights and freedoms in armed conflict as an object of administrative and legal support

The article emphasizes that in the theory of administrative law the object is in most cases considered as an element of the formal composition of administrative-legal relations. According to leading scholars-administrators, the object of administrativelegal relations is the tangible or intangible good, the use or protection of which is aimed at the subjective rights and legal obligations of the participants in administrative-legal relations. These are tangible or intangible benefits, as well as certain actions for which the subjects enter into administrative and legal relations. Human and civil rights are an object of administrative law, as they are natural and (or) enshrined in the Constitution, other laws of Ukraine and international fundamental legal acts ratified by the Verkhovna Rada of Ukraine. According to this, the right to life and health is not an inalienable right of any person under the jurisdiction of Ukraine. It is determined that the International Humanitarian Law does not contain a prohibition on waging war - this prohibition is contained in other norms of international law. International humanitarian law is applied only in the event of an armed conflict and is created by states precisely to impose certain limits on violence during the war, to limit suffering, and to protect the victims of war. It has been found that international humanitarian law does not prohibit the use of weapons to disarm combatants, by killing, wounding or inflicting severe psychological trauma in combat. Combatants of any party to the conflict have the right to directly participate in hostilities. International humanitarian law prohibits the use of military force against non-combatants and civilians. It is concluded that the rights and freedoms of man and citizen in armed conflicts in Ukraine, as an object of administrative and legal support - are not material (life, health, honor, dignity, etc.) and material (food, housing, clothing, finance, etc.) values that are in accordance with the given competence in the process of providing administrative services and executive activities are provided by the subjects of public administration to persons affected by the armed conflict.

Key words: administrative and legal support, administrative services, armed conflict, competence, executive activity, human rights and freedoms, non-material values.

Постановка проблеми. На початку 2014 року український народ вступив у збройний опір російськотерористичним військам, які до цього анексували Автономну Республіку Крим і розпочали терористичні заходи на українському Донбасі. 3 того часу (формально з 13 квітня 2014 року) держава та громадяни Україна опинилися у новій політичній, військовій, соціальній, економічній, психологічній та правовій парадигмі, яку можна охарактеризувати з погляду психології як шок. Дуже мала кількість громадян України до цього вба-

(C) О. П. Махмурова-Дишлюк, 2020 
чали у Російській Федерації ворога. Проте з позиції міжнародного досвіду усе йшло до цього. Українському суспільству треба було робити висновки з Карабахського військового конфлікту, який розпочався у 1988 році і продовжується досі, Сербської військової агресії проти Хорватії (1991 рік), Придністровського військового конфлікту 1992 року, Російсько-Чеченських війн (1994-1966 та 1999-2009 роки), Російсько-Грузинської війни (2008 рік). В усіх цих військових конфліктах прямо чи опосередковано бере участь Росія, керівництво якої прагне до повернення до політичної утопії - відновлення Рузського миру в територіальних межах часів радянської імперії. Зрозуміло й логічно, що без захоплення України це здійснити неможливо. Отже, у 2014 році російська влада розпочала військову агресію проти України, оперюючись на місцевих сепаратистів. Хоча завдяки збройному опору добробатів, Збройних Сил України, військовослужбовців МВС України, Прикордонних військ російсько-терористичним військам не вдалося досягти вагомих успіхів, проте частина українських територій опинилась під окупацією, а на лінії розмежування продовжується «гарячий» військовий конфлікт, наслідками якого є порушення прав, свобод та інтересів значної частини громадян України, здійснюючи професійний аналіз яких, не можемо не визначитися з об'єктом такого дослідження.

Аналіз останніх досліджень і публікацій. До проблеми адміністративно-правового забезпечення прав і свобод людини і громадянина в умовах збройних конфліктів в Україні звертали свої наукові погляди вітчизняні вчені, зокрема С. Бескоровайний, Я. Букреєв, А. Вишневський, В. Галунько, П. Діхтієвський, М. Доненко, Т. Короткий, О. Кузьменко, Ю. Лісова, С. Марущенко, О. Правоторова, Ю. Радковець, Є. Руденко, С. Сірий, Г. Христова. Проте вони аналізовану нами проблематику безпосередньо не досліджували, а зосереджували свої наукові пошуки та більш загальних, спеціальних чи суміжних викликах.

Метою статті $є$ розгляд прав і свобод людини та громадянина як об'єкта адміністративно-правового забезпечення в умовах збройного конфлікту в Україні.

Виклад основного матеріалу. Згідно з тлумачним словником української мови, об’єкт - це:

1) пізнавана дійсність, що існує поза свідомістю людини і незалежно від неї;

2) явище, предмет, особа, на які спрямовано певну діяльність, увагу тощо; предмет наукового та іншого дослідження, спеціальної зацікавленості, компетенції; предмет, що розглядається задля його використання за призначенням, вивчення;

3) спеціальна певна одиниця (споруда, підприємство, ділянка місцевості тощо) господарського чи оборонного значення [1].

В цьому різноманітті енциклопедичних знань для нас найбільш слушним є друге твердження, використовуючи яке, ми можемо стверджувати, що об'єктом адміністративно-правового забезпечення прав і свобод людини й громадянина в умовах збройних конфліктів є явища, предмети, суб'єкти адміністративного права, на яких спрямовано адміністративну діяльність компетентних на це суб' єктів публічної адміністрації.

В теорії адміністративного права об'єкт здебільшого розглядається як елемент формального складу адміністративно-правових відносин. Як вважають провідні вчені-адміністративісти, об'єктом адміністративно-правових відносин є те матеріальне або нематеріальне благо, на використання чи охорону якого спрямовано суб'єктивні права та юридичні обов'язки учасників адміністративно-правових відносин. Це блага матеріальні або нематеріальні, а також певні дії, заради яких суб'єкти вступають в адміністративно-правові відносини. Об’єктом адміністративно-правових відносин може бути все, що здатне служити здійсненню публічних інтересів. Цю роль можуть відігравати права людини і громадянина, право власності й послуги інших осіб [2].

Права людини і громадянина є об’єктом адміністративного права, оскільки вони є природними та (або) закріпленими в Конституції, інших законах України та міжнародних основоположних нормативно-правових актах, які ратифіковані Верховною Радою України. Згідно з цим, незаперечним правом будь-якої особи, що перебуває під юрисдикцією України, є право на життя і здоров’я. Воно знайшло своє конституційно-правове закріплення в нормах Конституції України, згідно з якою життя, здоров’я, честь і гідність людини і громадянина визнаються найвищою соціальною цінністю в Україні [3].

Однак в умовах збройних конфліктів є своя специфіка, яка доводить, що право на життя і здоров’я в деяких надзвичайних випадках не є абсолютним, адже міжнародні нормативно-правові акти, такі як Гаазькі конвенції про закони та звичаї війни 1899 і 1907 років, не забороняють війну як таку, а тільки обмежують засоби ведення війни щодо вбивства і виведення комбатантів противника із строю шляхом завдання шкоди здоров’ю, а також застосування військової сили щодо певних категорій осіб [4].

Згідно з IV Конвенцією про закони і звичаї війни, військові закони, права і обов’язки застосовуються не лише до армій, але й до ополчення та добровольчих загонів, якщо вони відповідають таким умовам: перебувають під командуванням особи, відповідальної за своїх підлеглих; мають закріплену відмітну емблему, яка може бути впізнана на відстані; відкрито носять зброю; ведуть бойові дії відповідно до законів і звичаїв війни. У країнах, в яких ополчення або добровольчі загони становлять армію чи входять до ії складу, вони включаються у категорію «армія» [6].

Отже, військовослужбовці України, які здійснюють антитерористичну операцію та (або) Операцію об’єднаних сил, є комбатантами, що беруть участь у збройному конфлікті. Більш того, комбатанти є особами зі складу російсько-терористичних військ за умови, що вони, дотримуючись законів і звичаїв війни відповідно до Гаазьких конвенцій про закони та звичаї війни, зокрема, не є найманцями. 
Поняття «Женевські конвенції» у більшості юристів слушно асоціюються з чотирма Женевськими конвенціями від 12 серпня 1949 року. Це чотири самостійних міжнародних договори, а саме Женевська конвенція про поліпшення долі поранених і хворих у діючих арміях; Женевська конвенція про поліпшення долі поранених, хворих та осіб, які зазнали корабельної аварії, зі складу збройних сил на морі; Женевська конвенція про поводження з військовополоненими; Женевська конвенція про захист цивільного населення під час війни. Їх зазвичай так і називають - «Женевські конвенції про захист жертв війни 1949 року». Унікальність цих конвенцій полягає в тому, що разом зі Статутом ООН вони є єдиними міжнародними договорами, у яких беруть участь усі держави. Це є свідоцтвом непорушної значущості їх норм та уособленням приналежності держави до міжнародного співтовариства. Заперечення, ігнорування фундаментальних норм, проголошених у цих конвенціях, ставить державу поза межею цивілізованого співтовариства, а дії індивіда кваліфікує як воєнні злочини поряд із агресією, геноцидом і злочинами проти людяності, які вважаються міжнародними злочинами і підпадають під юрисдикцію Міжнародного кримінального суду. Міжнародне гуманітарне право не містить заборони на ведення війни, цю заборону містять інші норми міжнародного права. Міжнародне гуманітарне право застосовується лише в разі збройного конфлікту та створено державами саме для того, щоб накласти певні рамки на насильство під час війни, обмежити страждання, захистити жертв війни. Саме тому для досягнення мети, з якою його створили держави, Міжнародне гуманітарне право не оцінює правомірність чи неправомірність збройного конфлікту, рівною мірою може застосовуватися до жертви й агресора, не потребує взаємності [5].

Іншими словами, Міжнародне гуманітарне право не забороняє застосовувати зброю задля виведення комбатантів зі строю шляхом вбивства, поранення чи нанесення важких психологічних травм у бою. Комбати будь-якої сторони конфлікту мають право безпосередньо брати участь у військових діях. Міжнародне гуманітарне право забороняє застосування військової сили щодо не комбатантів та цивільних осіб.

Отже, в умовах збройних конфліктів життя і здоров'я будь-яких цивільних осіб та не комбатантів є об'єктом адміністративно-правового забезпечення прав і свобод людини і громадянина. В умовах збройного конфлікту ці найвищі соціальні цінності характеризується тим, що сторони конфлікту не тільки не мають права їх порушувати, але й мають їх захищати і забезпечувати усіма доступними засобами.

Водночас життя, здоров’я і свобода комбатантів, які беруть участь у збройному конфлікті, не є абсолютними. Кожний із них у такому конфлікті без страху кримінального покарання (за умови не скоєння злочинів проти людяності) здійснює бойові дії, зокрема, метою яких є знищення живої сили противника. Проте такі дії не є об’єктом адміністративно-правового забезпечення в аналізованій сфері, оскільки регулюються нормами міжнародного права.

Щодо майнових об'єктів адміністративно-правового забезпечення в умовах збройних конфліктів, то тут треба зазначити, що ними є медичні, соціальні, фінансові, житлові, транспортні та інші матеріальні засоби, які надаються суб'єктами публічної адміністрації в процесі здійснення адміністративної діяльності особам, що постраждали внаслідок збройного конфлікту. Наприклад, 5 серпня 2020 року своїм Розпорядженням Кабінет Міністрів України виділив 5,6 мільйона гривень на придбання 18 квартир і 1 одного будинку для тимчасового проживання приблизно 55 внутрішньо переміщених осіб [7].

Висновки $з$ дослідження і перспективи подальших розвідок у цьому напрямі. Отже, права і свободи людини та громадянина в умовах збройних конфліктів в Україні як об’єкт адміністративно-правового забезпечення - це нематеріальні (життя, здоров’я, честь, гідність тощо) та матеріальні (харчування, житло, одяг, фінанси тощо) цінності, які, відповідно до наданої компетенції, в процесі надання адміністративних послуг та виконавчої діяльності надаються суб'єктами публічної адміністрації особам, що постраждали внаслідок збройного конфлікту.

\section{Список використаних джерел:}

1. Об’єкт. Великий тлумачний словник сучасної мови. 2020. URL: https://slovnyk.me/dict/vts/oб_єкт.

2. Адміністративне право України. Т. 1 : Загальне адміністративне право : навчальний посібник / В. Галунько, В. Курило, С. Короєд, О. Дрозд, І. Гиренко, О. Сщук, І. Риженко, А. Іванищук, Р. Саунін, І. Ямкова. Херсон : Грінь Д.С., 2015. 272 с.

3. Конституція України // Офіційний сайт Верховної Ради України. 2020. URL: https://zakon.rada.gov.ua/ laws/show/254к/96-вр\#Text.

4. Гаазькі конвенції про закони та звичаї війни 1899 і 1907. Енщиклопедія сучасної науки. 2020. URL: http://esu.com.ua/search_articles.php?id=27901.

5. Короткий Т., Доненко М. На варті гуманності. Женевські конвенції 1949. Юридична газета. 2020. URL: https://yur-gazeta.com/dumka-eksperta/na-varti-gumannosti-zhenevski-konvenciyi-1949.html.

6. IV Конвенція про закони і звичаї війни на суходолі та додаток до неї : Положення про закони і звичаї війни на суходолі 1907 року // Офіційний сайт Верховної Ради України. 2020. URL: https://zakon.rada.gov.ua/ laws/show/995 222\#Text.

7. Кабмін виділив 5,6 мільйона на придбання житла для переселенців. Економічна правда. 2010. URL: https://www.epravda.com.ua/news/2020/08/5/663725. 
УДК 340.12:342.7

DOI https://doi.org/10.32836/2521-6473.2020-4.8

\author{
Є.А. Кобрусєва, кандидат юридичних наук, доцент, \\ доцент кафедри адміністративного і кримінального права \\ Дніпровського національного університету імені Олеся Гончара
}

\title{
СУДОВИЙ РОЗГЛЯД СПРАВ У ПРОВАДЖЕННЯХ ЩОДО МИРНИХ ЗІБРАНЬ
}

Стаття присвячена здійсненню аналізу судового розгляду справ у провадженнях щодо мирних зібрань. Автором проведено ретроспективне дослідження вітчизняної судової практики розгляу справ про мирні зібрання, починаючи з пчатку 2000 років та до теперішнього часу. Здійснено аналіз розгляду кримінальних справ щодо відповідальності за незаконне втручання в мирні зібрання. Наголошується увага на необхідності уніфікованого підходу суддів до розгляду справ про мирні зібрання.

Зміни, ще відбуваються в українському суспільстві, пробуджують високу активність та прагнення людей брати безпосередню участь у вирішенні проблем, які стосуються їх загальних інтересів, зокрема й з використанням права на мирні зібрання. Втім, незважаючи на всю важливість саме иъього різновиду політичних прав, конститучійні положення про свободу зборів, мітингів, вуличних походів і демонстрачій й дотепер належним чином не конкретизовані в поточному законодавстві, нерідко обмежуються, а то і просто порушуються.

Спираючись на міжнародний досвід врегулювання права на мирні зібрання, запропоновано шляхи підвищення ефективності механізму адміністративно-правового забезпечення права на мирні зібрання, які полягають у створення внутрішньодержавного механізму контролю за дотриманням міжнародних стандартів прав та свобод людини, а також розвитку можливостей звернення до Європейського суду з прав людини, якщо та чи інша проблема не вирішена на національному рівні. Доведено, шо навіть досить невелике коло чинних норм, шо закріплені у законодавчих актах різного рівня, які гарантують забезпечення права на мирні зібрання, нерідко виявляють певну неузгодженість у змісті окреслених прав, особливо з позииій суб'єктів права на свободу мирних зібрань: Конституиія України таким суб' єктом називає громадянина, а иивільне законодавство - фізичну особу. Доведено необхідність впровадження міжнародних стандартів забезпечення права на мирні зібрання, насамперед стандартів європейської спільноти, що пов'язано з євроінтеграційними прагненнями Украӥни. Адже впровадження європейських стандартів і дотримання їх суб' 'єтами публічної адміністращії є однією з передумов інтеграціі України в європейський правовий простір.

Ключові слова: судова практика, мирні зібрання, мітинги, розгляд справ, зібрання.

\section{Ye. A. Kobrusieva. Judicial proceedings in peaceful assembly proceedings}

The article is devoted to the analysis of court proceedings in proceedings concerning peaceful assemblies. The author conducted a retrospective study of domestic judicial practice in peaceful assemblies from the early 2000 s to the present. The analysis of consideration of criminal cases concerning responsibility for illegal interference in peaceful assemblies is carried out. Emphasis is placed on the need for a unified approach of judges to the consideration of cases of peaceful assemblies.

The changes taking place in Ukrainian society arouse high activity and the desire of people to take a direct part in solving problems that concern their common interests, including the use of the right to peaceful assembly. However, despite the importance of this type of political rights, the constitutional provisions on freedom of assembly, assembly, street demonstrations and demonstrations, which are still not properly specified in the current legislation, are often limited or even violated.

Based on the international experience of regulating the right to peaceful assembly, ways to increase the effectiveness of the mechanism of administrative and legal support of the right to peaceful assembly are proposed, which are to create a domestic mechanism to monitor compliance with international standards of human rights and freedoms. human being, if this or that problem is not solved at the national level. It is proved that even a rather small range of current norms enshrined in legislative acts of various levels, which guarantee the right to peaceful assembly, often show some inconsistency in the content of the outlined rights, especially from the standpoint of the right to freedom of peaceful assembly. the subject is called a citizen, and civil law - an individual. The necessity of introduction of international standards of ensuring the right to peaceful assembly, first of all the standards of the European community, which is connected with the European integration aspirations of Ukraine, is proved. After all, the implementation of European standards and their observance by the subjects of public administration is one of the preconditions for Ukraine's integration into the European legal space.

Key words: judicial practice, peaceful assemblies, rallies, hearings, meetings.

Постановка проблеми. Вже досить тривалий період часу мирні зібрання відіграють важливу роль у політичній та соціальній частині житті будь-якої країни. Врешті-решт, такі зібрання $є$ роздільною ланкою між суспільством і державою, які відображують сподівання громадськості і, як влучно висловився 16-й президент США, не що інше, як конституційний замінник революції [1].

Задля підтвердження викладеного зазначимо, що право на мирні зібрання залишається основним правом, яке задовго до сьогодення визначало українську історію. Наведемо приклад, що за часи національно-визвольної боротьби 1917-1918 і 1990-1991 років великі демонстрації свідчили про прагнення українського народу жити в окремому суверенній державі. У той же час мирні зібрання зіграли важливу роль в 2004 і 2013-2014 роках в запобіганні установлення авторитарних диктаторських режимів в Україні.

Метою даної статті є визначення правового забезпечення при судовому розгляді справ щодо захисту права на мирні зібрання. Досягнення цієї мети передбачає вирішення таких завдань:

- охарактеризувати захист прав громадян як ознаку та основну функцію правової держави в судовому процесі;

- проаналізувати зміст судового захисту в сфері забезпечення реалізації права на мирні зібрання.

Аналіз останніх досліджень і публікацій. Наразі, право на мирні зібрання є конституційним правом кожного громадянина, що закріплено в Конституції України, а саме в Розділі II Права, свободи та обов’язки людини і громадянина наряду з іншими невід'ємними права та свободами людини [2]. 3 огляду на це воно повинно на 
належному рівні захищатись державою. Зокрема, для захисту прав та свобод людини в нашій країні існують норми різних галузей права, за вчинення зазначених в їх диспозиції діянь передбачене відповідна відповідальність. Найбільш суспільно-небезпечні діяння караються санкцією Кримінального кодексу України (далі - КК України). Однак, існування норм лише матеріального права недостатньо для належного захисту прав та свобод людини. Саме з цією метою діє Кримінальний процесуальний кодекс України (далі - КПК України), положення якого приводять в дію матеріальні норми КК України.

Зважаючи на вищенаведене варто відзначити звіт Спеціального доповідача ООН в одному з його щорічних звітів: «Захист свободи мирних зібрань та об’єднань громадян на різносторонніх ступенях починається 3 точних правил, але може стати реальністю лише в поєднанні з вдалою реалізацією їх в життя» [3, с. 13].

Виклад основного матеріалу. Згідно з вітчизняним законодавством, суди повинні грати особливо важливу роль у формуванні національної практики у частині реалізації права на мирні зібрання. Таким чином, згідно з Конституцією України, правосуддя в Україні здійснюється виключно суддями [2]. Виключно судова владі надані повноваження на оцінку законності будь-яких адміністративних рішень влади, які прямо чи опосередковано впливають на здійснення права на мирні зібрання в Україні або залучити учасників мирних зібрань до відповідальності. право

Крім того, слід зазначити, що обмеження реалізація права на мирні зібрання відповідно до ст. 39 Конституції України, може встановлюватися виключно в інтересах національної безпеки та громадського порядку з метою запобігання масовим заворушенням чи злочинам, для захисту здоров'я населення або захисту прав і свобод інших осіб [2].

Крім того, ст. 340 КК України передбачає відповідальність за незаконне перешкоджання організації або проведенню зборів, мітингів, походів і демонстрацій [4]. Слід підкреслити, що дана кримінальна злочин $є$ злочином, який підтверджує необхідність захисту досліджуваного конституційного закону і важливість проведення мирних зібрань. Проте, незважаючи на збільшення можливостей захистити свободу мирних зібрань, українська юриспруденція демонструє чітку залежність від політичного режиму, який практично визначає ії направленість.

Окрім законодавчого визначення положень про мирні зібрання, помітним фактором судової практики був радянський менталітет, який чітко підпорядковував інтереси особи інтересам колективу в тому сенсі, в якому ці інтереси враховувалися владою.

Влучним прикладом цього менталітету може бути витяг з рішення Мукачівського районного суду на початку 2000-х років, в якому суд буквально заявив, що «він боїться можливості будь-яких порушень громадської безпеки під час мирних зібрань» і тому повинен бути заборонений [5, с. 41]. Саме цей «страх» послужив керівним принципом і скерував більшість судів враховувати його при вирішенні справ, що стосується мирних зібрань.

Трохи згодом, в 2005-2009 роках, після Помаранчевої Революції, в українській судовій практиці відбуваються зміни, спрямовані на лібералізацію права на мирні зібрання [6]. Більшою мірою це пов'язано 3 масштабною кількістю мирних протестів по всій Україні в ті часи. Однак, поряд 3 цим, слід зазначити, що зміни торкнулися лише судової практики (законодавство змін не зазнало). Зокрема, суди почали активно впроваджувати європейський досвід.

Проте, така ситуація тривала недовго. Після приходу до влади у 2010 році на Віктора Януковича, судова практика у частині реалізації права на мирні зібрання одразу ж почала погіршуватись.

Зокрема, у перші роки його правління кількість позовів проти мирних зібрань майже подвоїлася, а кількість судових рішень, що обмежують свободу мирних зібрань, зросла на 10\% [7].

У наступні роки вказаний показник залишався на стабільно високому рівні. Зокрема, відсоток судових заборон коливався від 80 до 90\% [7].

Пік репресій проти учасників мирних зібрань припав на події Євромайдану, оскільки тодішній уряд вважав заборону мирних зібрань одним із способів протидії масовим протестам. У цей період суд формально посилався на причини заборони проведення мітингів через несвоєчасне подання повідомлень про мирні мітинги та нездатність поліції підтримувати правопорядок.

У деяких випадках влада має серйозні занепокоєння щодо охорони здоров’я. Наприклад, у Харкові мер міста видав указ про заборону масових заходів» від 22 листопада 2013 року в начебто через збільшення кількості гострих респіраторних захворювань. У той же час мер не міг не помітити, що Основний Закон нашої держави уповноважує лише суд обмежити здійснення права на мирні зібрання. У Луганську суд також ілюзорно був занепокоєний здоров’ям населення. Він визнав, що «здійснення неконтрольованих масових акцій у громадських місцях міста, не обладнаних спеціальними санітарно-технічними засобами, виявлення значної кількості людей, можуть спричинити шкідливі наслідки для громадян, які проживають або працюють поруч». У той же час суд не взяв до уваги, що на той час великі збори людей відбувалися в торгових центрах, транспортних засобах або масові заходи для святкування Нового року, де також відсутні будь-які санітарні обладнання [6].

Ще одна тенденція в юридичній практиці - велика кількість автоматичних судових заборон, тобто заборона всім громадянам проводити мирні зібрання протягом тривалого періоду часу, незалежно від того, заявили вони про свій намір проводити їх.

За даними Єдиного державного реєстру судових рішень, ми виявили 25 автоматичних рішень за період з 22 листопада 2013 року по 20 лютого 2014 року. Найбільша кількість автоматичних судових заборон за самі тривалі періоди часу мало місце в практиці Київського району. Адміністративний суд. Зокрема, цей суд заборонив всім суб'єктам, «які мають намір реалізувати право на мирні зібрання, проводити заходи (пікетування, прогулянки, демонстрації, мітинги, сходи і т. д.) На вул. Івана Франка в селі Новій Петрівці Вишгородського району. Київської області з 1 лютого 2014 р. по 1 квітня 2014 р. »[8].

Щоб повністю розібратися в ситуації, пропонуємо розглянути умови, при яких мітинги, протести, акції протесту вважаються мирними і допустимими в Україні.

Зокрема, їх організатори та виконавці повинні дотримуватися таких умов:

а) місце зборів і мітингів, маршрут демонстрацій повинно визначатися їх організаторами, про що своєчасно повідомляються виконавчі органи сільських, селищних, міських рад; 
б) ці заходи носять мирний характер і здійснюються без зброї;

c) не проводяться під час воєнного чи надзвичайного стану, воєнного, але компетентні органи не накладають обмежень на їх поведінку;

г) їх проведення не заборонено рішенням суду [9, с. 6].

Однак, поряд 3 цим слід звернути увагу, що суди приймаючи рішення про дозвіл чи заборону проведення мирних зібрань також виходять з вказаних вимог, тому, відповідно, заборони, видані судами в ті роки були прийняті з порушенням принципів пропорційності заходів адміністративного впливу:

1) принцип придатності, тобто даний захід зможе бути доречним та можливим для досягнення поставленої мети.

2) Принцип необхідності, означає, що серед кількох придатних заходів держава обрала той, який найменше впливав на людину та на соціум в цілому

3) принцип заборони перебільшення, тобто захід не слід проводити, якщо очікувані негативні наслідки переважають очікуваний результат [10]

Це також узгоджується з позицією, закріпленою в Керівних принципах ОБСС щодо свободи мирних зібрань: «Автоматичне застосування правових обмежень - наприклад, заборона будь-яких публічних виступів у будь-який час або у публічних місцях призводить до занадто багатьох заходів. Тому ці обмеження не пройдуть перевірку пропорційності, оскільки особливі обставини не враховувались у кожному окремому випадку» [10].

Окремі зміни в юридичній практиці щодо судової практики відбулися після чергової зміни уряду в результаті Революції гідності.

Відповідно до судової статистики, в 2014 році суди першої інстанції розглянули 112 позовів про обмеження мирних зібрань (найбільше з січня по лютий 201), 85 з яких призвели до обмеження свободи мирних зібрань (76\%). У 2015 році суди обмежили мирні зібрання в 20 випадках (53\%), в 2016 році - в 8 випадках (53\%), а в 2017 році взагалі не заборонили мирні зібрання, при цьому відмовившись прийняти позов про обмеження мирних зібрань шість разів [11].

Таким чином, ми можемо зробити висновок, що періоди терпимого ставлення судів до проведення мирних зібрань змінилися періодами менш лояльного ставлення в періоди політичних змін в державі. Ці дані дозволяють нам підозрювати наявність політичної складової при судовому розгляді справ цієї категорії, а також служать аргументом на користь наявності залежності судів від виконавчої влади.

Вказане може бути підтверджене не тільки радикальною зміною юридичної практики, а й вироками у кримінальних справах. Зокрема, мер одного з районних центрів був засуджений за підробку в 2014 році документів, що містять неправдиву інформацію про загрозу життю та здоров’ю людей, які будуть відвідувати мирні зібрання. За словами очевидців, мер в той час вимагав від своїх підлеглих виконувати вказівки невстановлених людей з Києва, щоб створити умови для заборони акцій протесту [5].

Поряд 3 викладеним слід наголосити, що не дивлячись на значні поліпшення судової практики у справах про мирні зібрання, наразі суди не дотримуються єдиної позиції. В різних регіонах суди дотримуються неоднакової позиції щодо дозволу або заборони проведення мирних зібрань.

Через відсутність однаковості юридичної практики у використанні джерел права на мирні зібрання відбувається безсумнівне порушення принципу правової визначеності. Відповідно до цього принципу, будь-яка особа повинна мати можливість 3 достатньою впевненістю передбачити наслідки своєї законної чи незаконної поведінки. Однак у випадках мирних зібрань громадянам відмовляють у такій можливості.

Ще однією нагальною проблемою юридичної практики, навіть після пом'якшення після Революції Гідності, є нехтування чи спотворення правових позицій Європейського суду з прав людини.

Свропейська конвенція 3 прав людини вважається фундаментальним договором у сфері захисту прав людини, в рамках якого функціонує ефективний контрольний механізм захисту закріплених прав, у тому числі права на свободу мирних зібрань.

Конвенція у статті 11 зобов’язує держави поважати свободу мирних зібрань, встановлюючи це право для кожного, та водночас передбачає можливість її обмеження. Тлумачення закріпленої свободи, як і деталізація критеріїв правомірності втручання держави в її реалізацію, було надано у практиці Свропейського суду 3 прав людини. Суд завжди зважав на тісний зв'язок свободи мирних зібрань з іншими правами, головним чином зі свободою вираження поглядів, що відображено у статті 10 Конвенції. Тому Свропейський суд, незважаючи на автономну роль та особливу сферу застосування, часто розглядає статтю 11 у світлі свободи вираження поглядів, що є однією з цілей свободи мирних зборів [12, с. 186] та одним зі способів іії реалізації.

Замість цього Харківський окружний адміністративний суд ухвалив заборонити мирні зібрання на підставі, яке прямо суперечить принципам Свропейського суду.

Зокрема, суд заборонив проведення мирних зібрань з закликом до зниження тарифів, даючи при цьому абстрактне посилання на «напружену суспільно-політичну ситуацію в місті». Суд також взяв до уваги той факт, що мітинг «призначений на обідню перерву в робочий день в центральній адміністративної частини міста, яка знаходиться в безпосередній близькості від державних органів та органів місцевого самоврядування на місці масового збору біля найбільшої кількості пасажирів станцій метро зупинок громадського транспорту» [12, с. 189].

У той же час національний суд не взяв до уваги позицію Європейського суду про те, що «будь-яка демонстрація в громадському місці неминуче порушує певною мірою загальний життєвий шлях, включаючи втручання в дорожній рух, і влада повинна показати деякі толерантність до мирних зібрань «(Сергій Кузнєцов проти Росії, № 10877/04, ЄСПЛ, 23 січня 2009 р., § 44). Крім того, згідно з Керівними принципами ОБСЄ щодо свободи мирних зібрань, «зустріч повинна проводитись у полі зору та слуху цільової аудиторії» (п. 3.5). Це правило не може бути реалізоване, якщо мирні зібрання заборонені «в безпосередній близькості від державних установ та органів місцевого самоврядування» [1].

Ще однією проблемою юриспруденції, яка залишається актуальною після 2014 року, є широке використання припущень як достатньої причини для обмеження свободи мирних зібрань. Однією 3 причин заборони мирних зібрань у рішенні Адміністративного суду Черкаського району № 54952265 від 13 січня 2016 року було зокрема 
те, що «інші громадяни, які поділяють думки протестуючих, можуть брати участь у цих заходах та навпаки інші люди, які не поділяють думки учасників. Тому кількість учасників може збільшитися до невизначеної кількості людей протягом певного періоду, що, у свою чергу, унеможливлює підтримку громадського порядку та захист прав і свобод інших людей» [13].

На наш погляд, судові рішення можуть базуватися на недоведеній гіпотезі, інакше мирні зібрання, наприклад у зв'язку з можливістю падіння метеору, можуть бути заборонені. Тобто існує ймовірність такого явища, але його реальність малоймовірна.

Також, досить незначною є показники судової практики щодо засудження осіб за вчинення злочину, передбаченого ст. 340 КК України. По-перше, нами було розглянуто статистичні дані Генеральної прокуратури України стосовно зареєстрованих кримінальних правопорушень та подальшого їх розгляду. Так, за останні 5 років було зареєстровано 212 злочинів, передбачених ст. 340 КК України, 3 яких лише 2 обвинувальних акти направлено до суду [14].

Звернувшись до Єдиного реєстру судових рішень, ми виявили 4 вироки суду за ст. 340 КК України, 3 яких 2 виправдувальних (вирок Деснянського районного суду м. Чернігова від 25.11.2016 [15]; вирок Деснянського районного суду м. Чернігова від 04.02.2016 [16]) та 2 обвинувальних вироки (Вирок ПереяславХмельницького міськрайонного суду Київської області від 16.05.2016 [17], Вирок Кіровського районного суду м. Дніпропетровська від 01.10.2015 [18]).

Висновки з дослідження і перспективи подальших розвідок у цьому напрямі. Таким чином, незважаючи на загальну тенденцію поліпшення за допомогою необгрунтованих судових заборон становища після Революції Гідності, деякі питання залишаються актуальними. Зокрема, на сьогоднішній день залишається невирішеною проблема, пов'язана реалізацією місцевими судами положень, які встановлюють обмеження проведення мирних зібрань. Існує проблема ігнорування і спотворення прецедентного права Європейського суду з прав людини, в якому суди продовжують робити припущення як дійсну основу для обмеження мирних зібрань. Крім цього, на даний час зберігається тенденція до не засудження осіб за вчинення злочину, передбаченого ст. 340 КК України, що простежується у низьких показниках направлення обвинувального акту за вказаною статтею до суду, або ж наявністю виправдувальних вироків.

\section{Список використаних джерел:}

1. Середа М. Судова практика у справах про мирні зібрання 2014: старі виклики і нові тенденції / Центр політико-правових реформ. URL: http://old.pravo.org.ua/politicreformandconstitutionslaw/humanrights/1867maksymsereda.html.

2. Конституція України: Закон України від 28.06.1996 р. Відомості Верховної Ради України (ВВР), 1996, № 30, ст. 141. Дата оновлення 01.01.2020. URL: https://zakon.rada.gov.ua/laws/show/254\%D0\%BA/96\%D0\%B2\%D $1 \% 80$ \#Text.

3. Доклад Специального докладчика по вопросу о правах на свободу мирных собраний и ассоциаций в контексте многосторонних учреждений /№ /69/365 от 01.09.2014 г. 30 c. URL: http://freeassembly.net/wp-content/ uploads/2014/10/Multilaterals-report-RU.pdf.

4. Кримінальний кодекс України: Закон України від 05.04.2001. Відомості Верховної Ради України (ВВР), 2001, №25-26, ст. 131. URL: https://zakon.rada.gov.ua/laws/show/2341-14\#Text.

5. Мельник Р. Форми мирних зібрань та їх характеристика через призму статті 39 Конституції України / Центр політико-правових реформ. 2019. URL: http://old.pravo.org.ua/politicreformandconstitutionslaw/ humanrights/1553-roman-melnyk.html.

6. Права людини в Україні 2009-2010. IX. Свобода мирних зібрань / Харківська правозахисна група. URL: http://khpg.org/m/index.php?id=1298306308.

7. Яка ситуація із мирними зібраннями сьогодні? / Центр політико-правових реформ. URL: http://pravo.org.ua/ua/meeting/sytuaciya/.

8. Постанова Київського окружного адміністративного суду № 36864074 від 28.01.2014 р.

9. Шкарнега О.С. Провадження у справах щодо реалізації права на мирні зібрання. Автореф. ... дис. канд. юрид. наук. 12.00.07. Одеса, 2016. 13 с.

10. Євтушок Ю. Принцип пропорційності та його вимоги у сфері законотворчості. Громадянське суспільство. 2020. № 22. URL: http://veche.kiev.ua/journal/3387/.

11. Статистичний аналіз судових рішень щодо заборони мирних зібрань, 2006-2018. Украӥнський цзентр суспільних даних. 23.12.2019. URL: https://socialdata.org.ua/4506-2/.

12. Шевчук С. Судовий захист прав людини. Практика Європейського суду з прав людини у контексті західної правової теорії. Київ : Реферат, 2017. 848 с.

13. Постанова Черкаського окружного адміністративного суду № 54952265 від 13.01 .2016 p.

14. Статистична інформація про стан злочинності та результати прокурорсько-слідчої діяльності. Генеральна прокуратура України. URL: https://old.gp.gov.ua/ua/stst2011.html?dir id=114140\&libid=100820.

15. Вирок Деснянського районного суду м. Чернігова від 25.11.2016 (справа №750/11733/15-к). URL: https://reyestr.court.gov.ua/Review/62958256.

16. Вирок Деснянського районного суду м. Чернігова від 04.02.2016 (справа №750/4139/15-к).

URL: https://reyestr.court.gov.ua/Review/55455134.

17. Вирок Переяслав-Хмельницького суду Київської області від 16.05.2016 (справа №373/2427/15-к). URL: https://reyestr.court.gov.ua/Review/57680610.

18. Вирок Кіровського районного суду м. Дніпропетровська від 01.10.2015 (справа № 203/1474/15-к). URL: https://reyestr.court.gov.ua/Review/51789830. 
УДК 347.73:336.02

DOI https://doi.org/10.32836/2521-6473.2020-4.9

\author{
Н. Ф. Скляр, аспірант кафедри \\ адміністративного та митного права \\ Університету митної справи та фрінансів, \\ головний державний інспектор відділу супроводження \\ судових спорів за плановими перевірками \\ управління правового забезпечення Головного управління \\ Державної податкової служби у Дніпропетровській області
}

\title{
ПРИНЦИПИ ФІНАНСОВОЇ ВІДПОВІДАЛЬНОСТІ ЗА ПОРУШЕННЯ ПОДАТКОВОГО ЗАКОНОДАВСТВА
}

Наукова стаття присвячена висвітленню принципів фінансової відповідальності за порушення податкового законодавства. Розглянуто загальні принциии фінансової відповідальності за порушення податкового законодавства, до яких віднесено принциии законності, справедливості, своєчасності, доцільності, невідворотності настання визначеної законом відповідальності у разі порушення податкового законодавства/притягнення до відповідальності, презумпиіі правомірності рімень платника податку. Проаналізовано проблемні питання правозастосування спеціальних приниипів фінансової відповідальності за порушення податкового законодавства, а саме принципу співвідношення фінансової відповідальності за порушення податкового законодавства та інших видів юридичної відповідальності, приниипу відмежування фінансової санкиії від фінансового обов'язку, принцииу ретроактивності фінансової відповідальності за порушення податкового законодавства та принщипу відповідальності на вину.

Зауважено, щзо в контексті реалізації принципу співвідношення фінансової відповідальності за порушення податкового законодавства з іншими видами юридичної відповідальності притягнення платника податків до фінансової відповідальності не виключає можливості застосування до останніх інших видів юридичної відповідальності.

Акиентовано увагу на особливості реалізації принципу відмежування фінансової санкиії від фінансового обов 'язку. Доведено, щзо накладення на платників податків штрафних (фінансових) санкиій (штрафів) за невиконання чи неналежне виконання покладених на них обов'язків не звільняє їх від необхідності виконання основного зобов 'язання.

Констатовано, щзо реалізація принцииу ретроактивності фінансової відповідальності за порушення податкового законодавства є виправданою лище в разі поліпшення становища платника податків.

Досліджено, що запроваджений принци відповідальності за «вину» в контексті регламентації процедури притягнення платників податків до фінансової відповідальності за податкові правопорушення є незавершеною конструкцією.

Звернено увагу на взаємозв'язок спеиіальних приничиів фінансової відповідальності за порушення податкового законодавства із загальними принципами фінансової відповідальності за порушення податкового законодавства, а також на взаємозумовленість загальних принципів фінансової відповідальності за порушення податкового законодавства з приниипами юридичної відповідальності.

Ключові слова: принципи юридичної відповідальності, фінансова відповідальність, відповідальність порушення податкового законодавства, податкове правопорушення, вина.

\section{N. F. Skliar. Principles of financial responsibility for violation of tax legislation}

The scientific article is devoted to the coverage of the principles of financial responsibility for violations of tax legislation. The general principles of financial responsibility for violation of tax legislation are considered, which include the principles: legality, fairness, timeliness, expediency, inevitability of liability under the law in case of violation of tax legislation/the principle of prosecution and the principle of presumption of legality of taxpayer decisions. Problematic issues of law enforcement of special principles of financial liability for violation of tax legislation are analyzed, namely: the principle of correlation of financial liability for violation of tax legislation with other types of legal liability, the principle of separation of financial sanction from financial obligation, the principle of retroactivity of financial liability for guilt.

It is noted that in the context of the implementation of the principle of correlation of financial liability for violation of tax legislation with other types of legal liability, bringing a taxpayer to financial responsibility does not exclude the possibility of applying legal liability to the latter.

Emphasis is placed on the peculiarity of the implementation of the principle of separation of financial sanctions from financial obligations. It is proved that the imposition of penalties (financial) sanctions (fines) on taxpayers for non-performance or improper performance of their duties does not release them from the need to perform the main obligation.

It is stated that the implementation of the principle of retroactivity of financial liability for violation of tax legislation is justified only if the situation of the taxpayer improves.

It is investigated that the introduced principle of liability for "guilt" in the context of regulating the procedure of bringing taxpayers to financial responsibility for tax offenses is an incomplete construction.

(C) Н. Ф. Скляр, 2020 
The article draws attention to the relationship of special principles of financial liability for violation of tax legislation with the general principles of financial liability for violation of tax legislation, as well as the interdependence of general principles of financial liability for violation of tax legislation with the principles of legal liability.

Key words: principles of legal responsibility, financial responsibility, responsibility of violation of tax legislation, tax offense, guilt.

Постановка проблеми. Трансформаційні процеси у податково-правовому регулюванні мають забезпечувати збалансування бюджетів за рахунок податкових надходжень та встановлювати справедливі умови для ведення бізнесу, враховуючи як потреби економічного розвитку, так і нові виклики, що стоять перед суспільством загалом. За даними рейтингу Playing Taxis 2020, що визначає легкість сплати податків, Україна спустилась на 11 позицій порівняно з минулим роком та посіла 65 місце серед 190 країн світу, які досліджувалися [1]. Втрата позицій України обумовлена перш за все активними діями інших держав, спрямованими на автоматизацію процесів і скорочення часу на адміністрування податків, збільшенням фіскального навантаження на бізнес у нашій країні, а також постійними динамічними змінами до податкового законодавства, які часто не враховують принципи останнього, збільшуючи їх декларативність. Водночас загальновизнаним $\epsilon$ те, що принципи податкового законодавства мають виступати орієнтиром для створення нових/зміни чинних та подальшої реалізації податково-правових норм. Водночас необхідною умовою забезпечення правопорядку у сфері податкових правовідносин $є$ встановлення відповідальності ( зокрема, фінансової) за їх невиконання або неналежне виконання. При цьому остання повинна базуватись на певній системі принципів, тобто основоположних засад, що покликані регулювати податкові відносини деліктного характеру.

Аналіз останніх досліджень і публікацій. Різні аспекти вивчення науково-практичних проблем у розгляді позначеної тематики належать 3.М. Будьку, О.І. Баїк, О.В. Муконіну, Р.Г. Браславському, М.П. Кучерявенку, А.О. Поляничку та іншим науковцяс. Однак, незважаючи на ступінь дослідження, в реаліях сьогодення систему основних засад податкового законодавства та, відповідно, виокремлених з них принципів фінансової відповідальності за порушення податкового законодавства не можна вважати остаточною, завершеною, вичерпною та сталою конструкцією, адже останні потребують додаткового аналізу та висвітлення.

Мета статті полягає у висвітленні принципів фінансової відповідальності за порушення податкового законодавства.

Виклад основного матеріалу. Принципи - це першооснови, центральні поняття предмета, процесу, діяльності. Принципи права - це основоположні начала, що визначають зміст і напрями правового регулювання загалом і кожної галузі зокрема. Стратегією сталого розвитку «Україна - 2020», що визначає мету, вектори руху, першочергові пріоритети та індикатори належних соціально-економічних, організаційних, політико-правових умов становлення та розвитку України, передбачається реформування податкової системи задля розвитку національної економіки. Головними напрямами реалізації податкової реформи є перехід від наглядово-каральної функції контролюючих органів до обслуговуючої, що допомагає у нарахуванні та проведенні сплати податків та не має на меті наповнення бюджету шляхом фінансових (штрафних) санкцій та переплат [2]. Водночас розвиток економіки потребує визначення єдиних та зрозумілих, а головне, сталих принципів оподаткування та, відповідно, принципів податкового законодавства. Між тим проблема останніх є предметом уваги дослідників, які представляють різні сфери суспільства. Насамперед це обумовлено тим, що податок розглядається як економічна, правова, соціальна, політична категорія, за допомогою якої задовольняються суспільні публічні потреби. При цьому для забезпечення належної алгоритмізації таких потреб на нормативному рівні повинні впроваджуватися керівні засади найвищої міри імперативності, які б систематизували та впорядковували податкові відносини з урахуванням своєї основоположності та логічно зумовленої конститутивності. Такими свого роду алгоритмізаторами $є$ принципи податкового законодавства, які отримують свою безпосередню формалізацію в межах приписів ст. 4 Податкового кодексу України [3, с. 156], з аналізу означення та конструювання яких вбачається певна специфіка, притаманна назві відповідної статті Податкового кодексу України.

Так, законодавець закріпив замість звичної для означення вихідних положень права терміносполуки «принципи податкового законодавства» поняття «основні засади податкового законодавства». Такий підхід можна пояснити тим, що в межах положень ст. 4 Податкового кодексу України, крім принципів податкового законодавства, своє закріплення отримали положення вихідного характеру, які наділені найвищою мірою імперативності, проте внаслідок неможливості їх концентрованого та лаконічного детермінування вони були викладені в межах поширювальних положень. Отже, у контексті ст. 4 Податкового кодексу України категорія «засади» $е$ ширшою за своїм змістовим наповненням, ніж поняття «принципи». Слово «засада», очевидно, застосоване законодавцем для того, щоб охопити як прямо закріплені принципи, так звані поіменовані, тобто чітко окреслені й формалізовані в належній лаконічній формі (п. 4.1 ст. 4 Податкового кодексу України), так і непрямо закріплені принципи, або «непоіменовані/приховані» (п. п 4.2-4.5 ст. 4 Податкового кодексу України). Зазначене підкреслює, що як система основних засад податкового законодавства, так і виокремлені з неї принципи фінансової відповідальності за порушення податкового законодавства не 
є остаточною, завершеною, вичерпною конструкцією, а з огляду на розвиток суспільних відносин потребують відповідного визначення та змістовного наповнення.

До цього часу в юридичній науці не сформувалося єдиної позиції щодо існування такого виду юридичної відповідальності, як фінансова, між тим очевидною є та обставина, що остання у всіх суттєвих моментах базується на принципах, характерних для юридичної відповідальності. Так, у правовій теорії можна зустріти такий перелік засад юридичної відповідальності: законність, обгрунтованість, доцільність, невідворотність, своєчасність, справедливість [4, с. 101]. Названі принципи 3.М. Будько вважає характерними для фінансово-правової відповідальності за вчинення податкових правопорушень [5].

При цьому О.В. Муконін доповнює зазначений перелік принципом правової захищеності суб'єктів економічних відносин. Розкриваючи сутність цього принципу, вчений вважає, що органи державного управління мають будувати свої відносини з підприємцями, не втручаючись у їх господарську діяльність, а лише здійснюючи контроль у межах та порядку, передбачених нормативно-правовими актами [6, с. 217].

O.І. Баїк зауважує, що до принципів фінансової відповідальності за порушення податкового законодавства, окрім зазначених вище, необхідно віднести неприпустимість подвоєння відповідальності та принцип індивідуалізації особи [7, с. 38]. Крім того, з аналізу наукових досліджень ученої вбачається, що перелік принципів фінансової відповідальності за порушення податкового законодавства є невичерпним.

Водночас Ю.В. Оніщик основну увагу зосереджує на принципі презумпції невинуватості. Правова позиція вченого грунтується на тому, що принцип презумпції невинуватості є ключовим для всіх видів юридичної відповідальності, отже, останній має бути властивий фінансовій відповідальності [8, с. 67]. На наш погляд, до зазначеного підходу необхідно підходити з обережністю, адже принципи юридичної відповідальності загалом, як і принципи фінансової відповідальності за порушення податкового законодавства зокрема, необхідно розглядати як системи, де кожен з елементів, що до них входить, взаємодіє між собою, тлумачиться і реалізовується з урахуванням інших основоположних ідей.

Як бачимо, у поглядах авторів на перелік принципів фінансової відповідальності за порушення податкового законодавства спостерігаються деякі розбіжності.

Не претендуючи на вичерпне визначення системи принципів фінансової відповідальності за порушення податкового законодавства, можливим є висвітлення загальних та спеціальних принципів фінансової відповідальності для цих правовідносин.

До загальних принципів фінансової відповідальності за порушення податкового законодавства можна віднести принципи законності, справедливості, своєчасності, доцільності, невідворотності настання визначеної законом відповідальності у разі порушення податкового законодавства або притягнення до відповідальності, презумпції правомірності рішень платника податку, якщо норма закону чи іншого нормативно-правового акта, виданого на підставі закону, або якщо норми різних законів чи різних нормативно-правових актів припускають неоднозначне (множинне) трактування прав та обов'язків платників податків або контролюючих органів, внаслідок чого є можливість прийняти рішення на користь як платника податків, так і контролюючого органу.

До спеціальних принципів фінансової відповідальності за порушення податкового законодавства належать принцип співвідношення фінансової відповідальності за порушення податкового законодавства та інших видів юридичної відповідальності, принцип відмежування фінансової санкції від фінансового обов'язку, принцип ретроактивності фінансової відповідальності за порушення податкового законодавства, принцип відповідальності на вину.

Охарактеризуємо проблемні питання застосування спеціальних принципів фінансової відповідальності за порушення податкового законодавства, адже загальні принципи неодноразово були предметом розгляду науковців у зазначеній сфері.

За загальним правилом принцип співвідношення фінансової відповідальності за порушення податкового законодавства з іншими видами юридичної відповідальності полягає у можливості застосування до платників податків інших видів відповідальності, окрім фінансової.

При цьому, відповідно до ст. 61 Конституції України, ніхто не може бути притягнутий до юридичної відповідальності одного виду за одне й те саме правопорушення [9].

Водночас, згідно зі ст. 111 ПК України, за порушення законів 3 питань оподаткування та іншого законодавства, контроль за дотриманням якого покладено на контролюючі органи, застосовуються такі види юридичної відповідальності, як фінансова, адміністративна, кримінальна.

Принцип співвідношення фінансової відповідальності за порушення податкового законодавства з іншими видами юридичної відповідальності знаходить свою безпосередню формалізацію у п. 112.1 ст. 112 ПК України та полягає у тому, що притягнення до фінансової відповідальності платників податків за порушення законів з питань оподаткування, іншого законодавства, контроль за дотриманням якого покладено на контролюючі органи, не звільняє останніх за наявності відповідних підстав від притягнення до адміністративної або кримінальної відповідальності [10].

3 процитованих положень чинного законодавства вбачається, що не виключена ситуація, за якої у разі вчинення одного правопорушення платник податків притягується до декількох видів відповідальності. 
Таким чином, у контексті принципу співвідношення фінансової відповідальності за порушення податкового законодавства та інших видів юридичної відповідальності притягнення платника податків до фінансової відповідальності все ж таки не виключає можливості застосування до останніх інших видів відповідальності залежно від характеру вчиненого ними діяння. Однак таку ситуацію навряд чи можна визнати допустимою у контексті практики Європейського суду з прав людини, яка, відповідно до ст. 17 Закону України «Про виконання рішень та застосування практики Європейського суду з прав людини» від 23 лютого 2006 р. № 3477-IV, застосовується національними судами як джерело права [11].

Так, у п. 52 рішення по справі «Остерлунд проти Фінляндії» (заява № 53197/13) фізичну особу спочатку було остаточно визнано винною у податковому шахрайстві (як злочині відповідно до національного законодавства), а згодом підтверджено законність нарахування податку та штрафів [12].

Це було визнано ЄСПЛ неприйнятним з точки зору принципу “non bis in idem” (двічі за одне й те ж правопорушення).

Другим спеціальним принципом фінансової відповідальності за порушення податкового законодавства можна назвати принцип відмежування фінансової санкції від фінансового обов’язку.

Відповідно до п. 113.2 ст. 113 ПК України, застосування штрафних (фінансових) санкцій (штрафів), передбачених главою 11 ПК України, не звільняє платників податків від обов'язку сплатити до бюджету належні суми податків і зборів, контроль за справлянням яких покладено на контролюючі органи, а також від застосування до них інших заходів, передбачених ПК України [10]. Із вищезазначеного вбачається, що особливість принципу відмежування фінансової санкції від фінансового обов'язку полягає в тому, що накладення на платників податків штрафних (фінансових) санкцій (штрафів) за невиконання чи неналежне виконання, покладених на них обов’язків не звільняє останніх від необхідності їх здійснення.

Наприклад, ст. 117 ПК України визначено фінансову відповідальність за порушення встановленого порядку взяття на облік (реєстрації) у контролюючих органах [10]. 3 аналізу цієї норми в контексті принципу, що розглядається, констатуємо, що накладення на платників податків штрафу у розмірах, визначених санкцією розглядуваної статті, не звільняє останніх від обов'язку подати заяви або документи для взяття на облік у відповідному контролюючому органі, вжити заходів для реєстрації змін місцезнаходження чи внесення інших змін до своїх облікових даних, подати виправлені документи для взяття на облік чи внесення змін або вжити заходів для подання без помилок та у повному обсязі відомостей стосовно осіб, відповідальних за ведення бухгалтерського обліку та/або складання звітності.

Крім того, ще одним прикладом реалізації принципу відмежування фінансової санкції від фінансового обов'язку є відступлення Великої Палати Верховного Суду в Постанові від 1 липня 2020 року по справі № 804/4602/16 від правової позиції, викладеної у Постанові Верховного Суду України від 6 квітня 2004 року № 8/140. Серед іншого суд дійшов висновку, що у разі несвоєчасного або перерахування не в повному обсязі суми податкового зобов'язання з вини банку платника такий платник звільняється від фінансової відповідальності у вигляді штрафу та/або пені, однак не звільняється від обов’язку сплатити в повному обсязі податкове зобов'язання [13].

Таким чином, звільнення платника податків від відповідальності за порушення строків погашення податкового зобов'язання не свідчить про звільнення від обов'язку виконати податкове зобов'язання.

Іншим спеціальним принципом фінансової відповідальності за порушення податкового законодавства, який не є текстуально закріпленим у ПК України, є принцип ретроактивності.

За загальним правилом зворотна дія нормативно-правового акта у часі (“ex post facto") - це дія нового нормативно-правового акта на факти та відносини, що мали місце до набуття ним чинності.

При цьому ст. 58 Конституції України гарантує зворотну дію у часі законів, які пом’якшують відповідальність особи [9]. Однак зазначена конституційна норма не має прямої дії стосовно відповідальності юридичних осіб з огляду, зокрема, на абзаци 3 та 4 п. 3 мотивувальної частини та п. 1 резолютивної частини Рішення Конституційного Суду України у справі за конституційним зверненням НБУ щодо офіційного тлумачення положення ч. 1 ст. 58 Конституції України (справа про зворотну дію в часі законів та інших нормативно-правових актів) від 9 лютого 1999 року № 1-рп/1999 [14].

У правовій доктрині європейських держав розрізняють два види ретроактивності, а саме формальну (власне ретроактивність) і матеріальну (ретроспективність). Формальна ретроактивність передбачає, що дата вступу в силу закону (всього або окремих його положень) передує моменту набуття ним чинності, тобто дія закону поширюється на правовідносини, що виникли до набуття ним чинності. Матеріальна ретроактивність (ретроспективність), навпаки, передбачає, що закон має миттєву силу, тобто дата вступу в силу та дата набуття чинності законом збігаються, однак він змінює на майбутнє правові наслідки подій, що мали місце до набуття ним чинності [15].

23 травня 2020 року набули чинності положення Закону України «Про внесення змін до Податкового кодексу України щодо вдосконалення адміністрування податків, усунення технічних та логічних неузгодженостей у податковому законодавстві» від 16 січня 2020 року № 466-IX [16].

Між іншого цим законодавчим актом доповнено підрозділ 2 розділу XX «Перехідні положення» ПК України п. 73. 
Так, відповідно до змісту п. 73 підрозділу 2 розділу ХХ «Перехідні положення» ПК України, штрафи за порушення платниками податку на додану вартість граничного строку для реєстрації податкової накладної та/або розрахунку коригування до такої податкової накладної в Сдиному реєстрі податкових накладних, передбаченого ст. 201 цього Кодексу, за операціями, що звільняються від оподаткування податком на додану вартість, операціями, що оподатковуються податком на додану вартість за нульовою ставкою, операціями, що не передбачають надання податкової накладної отримувачу (покупцю), а також податкової накладної, складеної відповідно до п. 198.5 ст. 198 цього Кодексу у разі здійснення операцій, визначених пп. пп. «а»-«г» п. 198.5 ст. 198 цього Кодексу, а також розрахунку коригування, складеного до такої податкової накладної, податкової накладної, складеної відповідно до ст. 199 цього Кодексу, та розрахунку коригування, складеного до такої податкової накладної, податкової накладної, складеної відповідно до абзацу одинадцятого п. 201.4 ст. 201 цього Кодексу, та розрахунку коригування, складеного до такої податкової накладної, нараховані платникам податків протягом періоду 31 січня 2017 року до дати набуття чинності Законом України «Про внесення змін до Податкового кодексу України щодо вдосконалення адміністрування податків, усунення технічних та логічних неузгодженостей у податковому законодавстві», строк сплати грошових зобов'язань за якими не настав або грошові зобов'язання за якими неузгоджені (відповідні податкові повідомлення-рішення перебувають у процедурі адміністративного або судового оскарження, а грошові зобов'язання за ними не сплачено) станом на дату набуття чинності Законом України «Про внесення змін до Податкового кодексу України щодо вдосконалення адміністрування податків, усунення технічних та логічних неузгодженостей у податковому законодавстві», застосовуються в розмірі 1\% обсягу постачання (без податку на додану вартість), але не більше 510 гривень.

Штрафи, застосовані через відсутність реєстрації протягом граничного строку, передбаченого ст. 201 цього Кодексу, податкової накладної та/або розрахунку коригування до такої податкової накладної в Сдиному реєстрі податкових накладних за операціями, що звільняються від оподаткування податком на додану вартість, операціями, що оподатковуються податком на додану вартість за нульовою ставкою, операціями, що не передбачають надання податкової накладної отримувачу (покупцю), а також податкової накладної, складеної відповідно до п. 198.5 ст. 198 цього Кодексу у разі здійснення операцій, визначених пп. пп. «а»-«г» п. 198.5 ст. 198 цього Кодексу, та розрахунку коригування, складеного до такої податкової накладної, податкової накладної, складеної відповідно до ст. 199 цього Кодексу, та розрахунку коригування, складеного до такої податкової накладної, податкової накладної, складеної відповідно до абзацу одинадцятого п. 201.4 ст. 201 цього Кодексу, та розрахунку коригування, складеного до такої податкової накладної, нараховані платникам податків протягом періоду з 1 січня 2017 року до дати набуття чинності Законом України «Про внесення змін до Податкового кодексу України щодо вдосконалення адміністрування податків, усунення технічних та логічних неузгодженостей у податковому законодавстві», строк сплати грошових зобов'язань за якими не настав або грошові зобов'язання за якими неузгоджені (відповідні податкові повідомлення-рішення перебувають у процедурі адміністративного або судового оскарження, а грошові зобов’ язання за ними не сплачено) станом на дату набуття чинності Законом України «Про внесення змін до Податкового кодексу України щодо вдосконалення адміністрування податків, усунення технічних та логічних неузгодженостей у податковому законодавстві», застосовуються в розмірі 2,5\% обсягу постачання (без податку на додану вартість), але не більше 1700 гривень [10].

Констатуємо, що такий підхід законодавця загалом відповідає принципу «доброго урядування» й «належної адміністрації» $з$ огляду на практику ССПЛ.

Так, в п. П. 70, 71 рішення по справі «Рисовський проти України» (заява № 29979/04) ЄСПЛ підкреслює особливу важливість принципу «належного урядування», зазначивши, що цей принцип передбачає, що коли йдеться про питання загального інтересу, зокрема, якщо справа впливає на такі основоположні права людини, як майнові права, то державні органи мають діяти вчасно та в належний і якомога послідовний спосіб [17].

Водночас у п. 73 рішення по справі «Москаль проти Польщі» (заява № 10373/05) ЄСПЛ зазначає, що принцип «належного урядування», як правило, не має перешкоджати державним органам виправляти випадкові помилки, навіть ті, причиною яких є їхня власна недбалість [18, с. 200].

За змістом наведеної норми законодавцем, який виявив певні недоліки (непропорційність) у механізмі фінансової відповідальності за несвоєчасну реєстрацію податкової накладної, що не надається покупцю товарів, передбачено реалізацію принципу зворотної дії положень п. 73 підрозділу 2 розділу ХХ «Перехідні положення» ПК України щодо порядку застосування штрафів за порушення платниками податку на додану вартість порядку реєстрації податкової накладної та/або розрахунку коригування до такої податкової накладної в Сдиному реєстрі податкових накладних протягом строку, передбаченого ст. 201 цього Кодексу, за операціями, визначеними таким пунктом, що проявляється в тому, що такі положення поширюють свою дію на всі штрафні санкції, нараховані платникам податків протягом періоду з 1 січня 2017 року до дати набуття чинності Законом № 466-IX, якщо відповідні податкові повідомлення-рішення перебувають у процедурі адміністративного або судового оскарження (без обмеження інстанційності судового розгляду), а грошові зобов’ язання за ними не сплачено станом на дату набуття чинності Законом № 466-IX [19]. 
Таким чином, реалізація принципу ретроактивності фінансової відповідальності за порушення податкового законодавства є виправданою лише в разі поліпшення становища платника податків.

Ще одним спеціальним принципом фінансової відповідальності є нещодавно впроваджений принцип відповідальності за «вину».

Законом № 466-IX визначено, що 31 січня 2021 року п. 109.1. ст. 109 ПК України має застосовуватись у такій редакції.

«Податковим правопорушенням є протиправне, винне (у випадках, прямо передбачених цим Кодексом) діяння (дія чи бездіяльність) платника податку (в тому числі осіб, прирівняних до нього), контролюючих органів та/або їх посадових (службових) осіб, інших суб'єктів у випадках, прямо передбачених цим Кодексом.

Діяння вважаються вчиненими умисно, якщо існують доведені контролюючим органом обставини, які свідчать, що платник податків удавано, цілеспрямовано створив умови, які не можуть мати іншої мети, крім як невиконання або неналежне виконання вимог, установлених цим Кодексом та іншим законодавством, контроль за дотриманням якого покладено на контролюючі органи» [16].

Запроваджений законодавцем принцип відповідальності за «вину», як і сама її незавершена конструкція, під час вчинення податкових правопорушень викликає більше запитань, ніж відповідей.

Так, зокрема, з аналізу тексту Закону № 466-IX випливає, що він не запроваджує як визначення вини, так і ії форми. За цих умов у разі відсутності цього поняття в ПК України, відповідно до положень п. 5.3 ст. 5 ПК України [10], вина має використовуватися у значенні, встановленому відповідним профільним законом, яким є Кримінальний кодекс України [20].

Отже, запроваджене визначення в Законі № 466-IX поняття податкового правопорушення передбачає можливість відсутності вини для кваліфікування діяння як правопорушення та, як наслідок, можливість відсутності такої ознаки об’єктивної сторони, як шкода.

Варто зауважити, що зазначене так чи інакше дає підстави для виокремлення й певних методологічних помилок під час визначення умов притягнення до фінансової відповідальності за порушення податкового законодавства.

Зокрема, п. 112.1 ст. 112 Закону № 466-IX передбачає, що особа може бути притягнута до фінансової відповідальності за вчинення податкового правопорушення за умови наявності в іiі діянні (дії або бездіяльності) вини, крім випадків, передбачених цим Кодексом.

До переліку випадків, для яких необхідною умовою притягнення особи до фінансової відповідальності за вчинення податкового правопорушення є встановлення контролюючими органами вини особи, додаються випадки, визначені п. 119.3 ст. 119 , п. п. 123.2-123.5 ст. 123 , п. п. $124.2,124.3$ ст. 124 , п. п. $125^{-1} .2-125^{-1} .4$ ст. $125^{-1}$ ПК України [16].

Таким чином, Закон № 466-IX передбачає можливість вжиття заходів фінансової відповідальності за відсутності вини в інших випадках, встановлених главою 11 ПК України та не зазначених п. 112.1 ст. 112 Закону № 466-IX.

Ще більшої незрозумілості під час майбутньої реалізації принципу відповідальності за «вину» вносить п. 112.2 ст. 112 Закону № 466-IX, за яким особа вважається винною у вчиненні правопорушення, якщо буде встановлено, що вона мала можливість для дотримання правил та норм, за порушення яких цим Кодексом передбачена відповідальність, проте не вжила достатніх заходів щодо їх дотримання [16]. Отже, за «моделлю» Закону № 466-IX особа вважається винною, якщо не дотримується відповідних правил та норм ПК України. Проте такий підхід не відповідає як визначенню вини за КК України [20], так і наявності об’єктивної сторони податкового правопорушення, оскільки не пов'язує визнання факту правопорушення й вини платника 3 наявністю чи можливістю настання суспільно небезпечних наслідків/шкоди від його діяння. Крім того, для реалізації цієї норми не розробленими є критерії визначення вини суб'єкта правопорушення та порядок її встановлення контролюючими органами.

Висновки $з$ дослідження і перспективи подальших розвідок у цьому напрямі. Системний аналіз податкового законодавства та наукових джерел свідчить про недостатнє дослідження проблеми принципів фінансової відповідальності за порушення податкового законодавства.

Наведене нами розмежування принципів фінансової відповідальності за порушення податкового законодавства на загальні та спеціальні не є вичерпним та безперечним. Однак з урахуванням специфіки податкових правовідносин до загальних принципів фінансової відповідальності за порушення податкового законодавства відносимо принципи законності, справедливості, своєчасності, доцільності, невідворотності настання визначеної законом відповідальності у разі порушення податкового законодавства/притягнення до відповідальності та презумпції правомірності рішень платника податку.

До спеціальних принципів фінансової відповідальності за порушення податкового законодавства належать принцип співвідношення фінансової відповідальності за порушення податкового законодавства та інших видів юридичної відповідальності, принцип відмежування фінансової санкції від фінансового обов'язку, принцип ретроактивності фінансової відповідальності за порушення податкового законодавства, принцип відповідальності на вину. 
У статті ми не торкалися розкриття змісту загальних принципів фінансової відповідальності за порушення податкового законодавства, проте підкреслюємо таке співвідношення: спеціальні принципи фінансової відповідальності за порушення податкового законодавства мають грунтуватися на загальних принципах фінансової відповідальності за порушення податкового законодавства, а останні - на принципах юридичної відповідальності.

Вирішення проблемних питань правозастосування спеціальних принципів фінансової відповідальності за порушення податкового законодавства залишається перспективним завданням національної правової системи, яке потребує подальшого дослідження.

\section{Список використаних джерел:}

1. Україна змінила позиції у світовому рейтингу зі сплати податків. Слово $i$ diлo. URL: https://ru.slovoidilo.ua/2019/11/26/novost/jekonomika/ukraina-izmenila-pozicii-mirovom-rejtinge-uplate-nalogov (дата звернення: 10.09.2020).

2. Про стратегію сталого розвитку «Україна - 2020» : Указ Президента України від 12 січня 2015 року № 5/2015. URL: https://zakon.rada.gov.ua/laws/show/5/2015 (дата звернення: 10.09.2020).

3. Браславський Р.Г. Система принципів податкового законодавства. Підприємництво, господарство $i$ право. 2017. № 9. С. 156-159.

4. Скакун О.Ф. Теорія держави і права : підручник / пер. з рос. Харків : Консум, 2001. 656 с.

5. Будько 3.М. Фінансово-правова відповідальність за вчинення податкових правопорушень : автореф. дис. ... канд. юрид. наук : спец. 12.00.07. Ірпінь, 2005. 18 с.

6. Муконін О.В. Поняття фінансово-правової відповідальності в оподаткуванні. Університетські наукові записки. 2005. № 3 (15). С. 216-220.

7. Баик О.И. О финансовой ответственности за нарушение налогового законодательства Украины. Norwegian Journal of development of the International Science. 2017. № 8. Vol. 3. P. 34-40.

8. Оніщик Ю.В. Актуальні питання відповідальності за порушення податкового законодавства. Науковий вісник Херсонського державного університету. Серія: Юридичні науки. 2015. № 1 (3). С. 66-69.

9. Конституція України : Закон України від 28 червня 1996 року № 254к/96-BP. URL: https://zakon.rada.gov.ua/laws/show/254\%D0\%BA/96-\%D0\%B2\%D1\%80\#Text (дата звернення: 10.09.2020).

10. Податковий кодекс України : Закон України від 2 грудня 2010 року № 2755-VI. URL: https://zakon.rada.gov.ua/laws/show/2755-17\#Техt (дата звернення: 09.09.2020).

11. Про виконання рішень та застосування практики Європейського суду з прав людини : Закон України від 23 лютого 2006 року № 3477-IV. URL: https://zakon.rada.gov.ua/laws/show/3477-15\#Техt (дата звернення: 09.09.2020).

12. Справа «Остерлунд проти Фінляндії» (заява № 53197/13) : Рішення Свропейського суду 3 прав людини від 10 лютого 2015 року. URL: http://kmp.ua/wp-content/uploads/2016/03/ECHR_Decision_CASE_ OF_\%C3\%96STERLUND_v._FINLAND.pdf (дата звернення: 08.09.2020).

13. Постанова Великої Палати Верховного Суду від 1 липня 2020 року по справі № 804/4602/16. URL: http://reyestr.court.gov.ua/Review/90228193 (дата звернення: 08.09.2020).

14. Рішення Конституційного Суду України у справі за конституційним зверненням Національного банку України стосовно офіційного тлумачення положення ч. 1 ст. 58 Конституції України (справа про зворотну дію в часі законів та інших нормативно-правових актів) від 9 лютого 1999 року № 1-рп/99. Офіüiŭний вісник України. 1999. № 7. Ст. 255.

15. Hans Gribnau Equality, Legal Certainty and Tax Legislation in the Netherlands Fundamental Legal Principles as Checks on Legislative Power: A Case Study. URL: http://www.utrechtlawreview.org/index.php/ulr/ article/view/227/222 (дата звернення: 08.09.2020).

16. Про внесення змін до Податкового кодексу України щодо вдосконалення адміністрування податків, усунення технічних та логічних неузгодженостей у податковому законодавстві : Закон України від 16 січня 2020 року № 466-IX. URL: https://zakon.rada.gov.ua/laws/show/466-20\#Text (дата звернення: 09.09.2020).

17. Справа «Рисовський проти України» (заява № 29979/04) (заява № 53197/13) : Рішення Європейського суду з прав людини від 20 жовтня 2011 року. URL: https://zakon.rada.gov.ua/laws/show/974_854\#Text (дата звернення: 08.09.2020).

18. Вибрані рішення Свропейського суду з прав людини щодо України - 2011. Ч. 2 / упоряд. С.Ю. Захаров. Харків : Права людини, 2017. 404 с.

19. Постанова Верховного Суду від 29 липня 2020 року по справі № 440/813/19. URL: http://reyestr.court.gov.ua/Review/90755107 (дата звернення: 08.09.2020).

20. Кримінальний кодекс України : Закон України від 29 червня 2001 року № 2341-III. URL: https://zakon.rada.gov.ua/laws/show/2341-14\#Техt (дата звернення: 09.09.2020). 
УДК $340+35.078 .3$

DOI https://doi.org/10.32836/2521-6473.2020-4.10

\author{
А. В. Тарасюк, кандидат юридичних наук, \\ головний науковий співробітник наукової лабораторії \\ забезпечення інформаційної та кібернетичної безпеки \\ Науково-дослідного інституту інформатики і права \\ Національної академії правових наук України
}

\title{
ТЕОРЕТИКО-ПРАВОВЕ ПІДГРУНТЯ ІНФОРМАЦЙНОЇ ЕТИКИ В СИСТЕМІ ЗАБЕЗПЕЧЕННЯ КІБЕРБЕЗПЕКИ
}

У статті досліджено питання впливу новащій у сфері інформаиійних технологій і використання кіберпростору на сферу прав і свободлюдини. Акиентовано увагуна проблемі наслідків їх застосування, актуалізовано потребу аналізувати і враховувати иі обставини з налаштуванням, зокрема, новітніх технологій на дотримання загальнолюдських иінностей. У ивому контексті здатність прогнозувати і впливати на иі процеси доводить інформаиійна етика. У статті досліджено тендениії розвитку й використання інформаційно-телекомунікаиійних технологій та кіберпростору, що дало підстави стверджувати, що одним із головних напрямів відповідної державної політики інформаційного суспільства є забезпечення організації та всебічного сприяння науковому пошуку в цій сфері, глибокому аналізу та надійному передбаченню результатів розроблення, впровадження й застосування новітніх технологій. Останні мають набути соиіального змісту й спрямовуватися на досягнення виключно гуманістичних иілей.

Упровадження морально-етичних норм у інформаційно-безпековій сфері потребує підтримки усього суспільства та інституиіоналізації, тобто держава має приймати закони, кодекси, нормативні акти тощо, котрі спрямовані на забезпечення прав і свобод людини в інформаційній сфері та кіберпросторі, а також створення чіткого й прозорого, доступного для кожного сочіального суб’єкта механізму їх реалізаиії. В умовах підвищення національних і міжнародно-правових безпекових стандартів нагальними завданнями сучасної світової спільноти стають повага й суворе дотримання ухвалених правових приписів. У межах прийнятої моделі інформаційної та кібербезпеки інформаційне суспільство має, зрештою, сформувати державну стратегію розвитку інформаиійно-телекомунікаиійних технологій та використання кіберпростору, передбачивщи в ній з'ясування основних пріоритетів суспільного розвитку та вироблення правових механізмів координування цих процесів. Комплексне наукове дослідження з урахуванням оптимального співвідношення усіх аспектів иього процесу, зокрема технічного, культурного, морально-етичного, $\epsilon$ його важливим чинником.

Ключові слова: кібербезпека, інформаиійна етика, захист інформаиії.

\section{A. V. Tarasyuk. Theoretical and legal basis of information ethics in the cyber security system}

The article examines the impact of innovations in the field of information technology and the use of cyberspace on human rights and freedoms. Emphasis is placed on the problem of the consequences of their use, the need is actualized, to analyze and take into account these circumstances, adjusting, in particular, the latest technologies for the observance of universal values. In this context, the ability to predict and influence these processes is proved by information ethics. The article examines the trends in the development and use of information and telecommunications technologies and cyberspace, which led to argue that one of the main directions of public policy information society should ensure the organization and comprehensive support of scientific research in this area, in-depth analysis and reliable prediction of development, implementation and the use of the latest technologies. The latter must acquire a social meaning and be aimed at achieving exclusively humanistic goals.

The introduction of moral and ethical norms in the information and security sphere requires the support of the whole society and institutionalization. That is, the state must adopt laws, codes, regulations, etc., which are aimed at ensuring human rights and freedoms in the information sphere and cyberspace, as well as the creation of a clear and transparent mechanism for their implementation by each social actor. In the conditions of increase of national and international legal safety standards the urgent task of the modern world community becomes respect and strict observance of the accepted legal instructions. Within the framework of the adopted model of information and cybersecurity, the information society should, ultimately, form a state strategy for the development of information and telecommunications technologies and the use of cyberspace, providing clarification of the main priorities of social development and legal mechanisms for coordinating these processes. Comprehensive scientific research taking into account the optimal ratio of all aspects of this process - technical, cultural, moral and ethical, etc. - is an important factor.

The main categories of social communities are also identified, for the regulation of relations in the information environment which requires the establishment of moral and ethical norms. These include teams of professional IT staff, the media, all user communities and individual users, various structures that have business relationships in cyberspace, educators and librarians working in a virtual environment, Internet service providers involved regulation of relevant content, etc.

Key words: cybersecurity, information ethics, information protection.

(C) А. В. Тарасюк, 2020 
Постановка проблеми. Регулювання питань свободи слова й доступу до інформації, відповідно до Конвенції про захист прав людини і основоположних свобод [1], пов'язане в демократичному суспільстві з обов'язками та відповідальністю. У нинішніх умовах виникає питання щодо пристосування цих регуляторів до кіберсередовища або створення спеціального документа, котрий регламентував би інтернет-відносини. Цю проблему аж ніяк не можна назвати простою. Справді, чи є такими ж неприпустимими у віртуальному просторі ті категорії інформації, які вважаються незаконними або неприйнятними в реальному житті, або ж специфіка глобальної мережі припускає існування особливих іiі форм, котрі потребують окремої регламентації?

До певної міри вирішити ці проблеми має, на нашу думку, інформаційна етика, зокрема, шляхом унормування функцій інтернет-посередників, адже відповідальність за наслідки діяльності останніх не передбачена європейським законодавством. Наведені вище приклади не вичерпують перелік недоліків у роботі інтернет-провайдерів, тому слід, вважаємо, розробити додаткові гарантії забезпечення ऑї прозорості. Ми погоджуємося з думкою Г. Миролюбенко про те, що інформаційна етика постає як спроба подолання нерегульованості інформаційно-комунікативного простору, привнесення етичної складової частини у відносини, які опосередковані технічними засобами [2, с. 311]. Цікавим є досвід США, де ще у 1979 році був прийнятий перший кодекс інформаційної етики, в преамбулі якого підкреслюється «життєво важлива необхідність дотримання всіх норм етики під час розроблення та експлуатації засобів інформаційних технологій» [3, с. 55-82].

Аналіз останніх досліджень і публікацій. В основу написання статті покладено творчий доробок вітчизняних науковців, серед яких варто виокремити праці О. Довганя, Т. Ткачука, Л. Філіпової, В. Зеленецького, Г. Миролюбенко.

Мета статті полягає у теоретико-правовому аналізі актуальних питань інформаційної етики як складової частини системи забезпечення кібербезпеки людини, суспільства й держави.

Виклад основного матеріалу. Ми цілком підтримуємо професора Кентського університету Томаса Фрейліха, котрий одним зі способів ефективного регулювання інформаційної взаємодії називав самоконтроль [4]. У контексті дослідження варто згадати технічні способи його здійснення, а саме застосування фільтраційних програм, функцій модераторів, розроблення технічних регламентів як програмного забезпечення для рейтингових і фільтраційних операцій.

На жаль, сучасна практика напрацювала поки що небагато зразків саморегулювання та спільного регулювання кінцевих користувачів. Одним із таких прикладів спільного регулювання мережевого контенту може слугувати загальнодоступна, відкрита, багатомовна універсальна інтернет-енциклопедія «Вікіпедія» (Wikipedia). До створення iii контенту, перевірки фактажу, редагування тощо залучається практично уся громадянська інформаційна спільнота. Як джерело найрізноманітнішої інформації це віртуальне видання набуло величезної популярності у користувачів всесвітньої мережі, попри те, що з огляду на свою специфіку воно не належить до наукових.

Правовідносини між розробниками цього інтернет-ресурсу, його численними авторами та користувачами регулюються зведенням офіційних правил «Вікіпедії». Усі суб'єкти, пов’язані з ресурсом, відповідно до цього своєрідного кодексу, не повинні допускати образ, зневажання, агресії та погроз, авторської багатоликості. Автори беруть на себе зобов'язання дотримуватися неупередженості, нейтралітету у своїх матеріалах, не оприлюднювати у статтях енциклопедії оригінальних досліджень, посилатися на джерела інформації, що ними подається. Категорично заборонено використання анонімних проксі-серверів, а в разі інших порушень порядок відновлюється за допомогою шляхетних перемов. Так звані правові основи переліку передбачають умови, що запобігають порушенню авторського права.

Як бачимо, запроваджені творцями «Вікіпедії» регулятивні заходи не лише сприяли підвищенню морально-етичної поінформованості інтернет-спільноти, але й загалом зумовили конструктивні, довірчі стосунки між їі учасниками.

Ще одним прикладом саморегулювання в технічному сенсі є проєкт (котрий нині успішно функціонує) «Створення інтернет-контенту» (Internet Content Generated), у межах якого передбачено генерування специфічного демократичного кіберсередовища (Internet Democracy Generated). Ці віртуальні утворення дають змогу користувачам у пошуках альтернативного управлінського інтернет-інструментарію дискутувати щодо моделей створення, розвитку й поширення інформації. Наприклад, моніторити інтернет-середовище для виявлення порушень правових та морально-етичних приписів можна сьогодні за допомогою платформи "Creative Commons" ${ }^{1}$ та інших подібних моделей, що виникають стихійно.

Таким чином, під час організації суспільних заходів слід застосовувати методи й засоби створення відповідної соціальної атмосфери, духу здорового корпоративізму. Крім того, необхідно уможливити ідентифікацію індивіда з конкретною соціальною спільнотою, прищепити почуття гордості за причетність до неї. Ці заходи мають також передбачати формування всередині цих соціальних утворень професійні та інші морально-етичні приписи й настанови, котрі визначають умови функціонування в інформаційному, кібернетичному середовищі та безпечного використання відповідних технологій.

${ }^{1}$ Creative Commons. URL: http://creativecommons.org 
Здійснюючи свою функцію духовного регулятора разом із традиційними правовими і моральними приписами й традиціями, інформаційна етика є важливим чинником формування морально-інформаційного середовища сучасного соціуму, зокрема окремих спільнот, груп, колективів, індивідуумів.

Уявляється, що морально-етичний кодекс має бути такою собі точкою тяжіння, доцентрові сили якої зумовлюють досягнення системою того кінцевого стану, якого вона прагне досягти. Наприклад, наслідком усвідомлення вагомості морально-етичного регулювання на рівні спільнот є актуалізація прагнення до вивчення принципів інформаційної етики, сприяння іiі правового та організаційного закріплення, а також, відповідно, вдосконалення етичних кодексів у сфері використання інформаційних технологій та кіберпростору.

Вважаємо, що підвалини ефективного функціонування системи кібернетичної безпеки закладаються ще на етапі проєктування новітніх інформаційних технологій у науково-дослідницьких лабораторіях послідовною, цілеспрямованою, професійно відповідальною роботою їх персоналу з обов'язковим урахуванням соціальних і морально-етичних наслідків застосування таких новацій. Завершальний користувач як кінцева ланка цієї послідовності має чітко розуміти основні засади функціонування конкретних інформаційних технологій та користування кіберпростором.

Запорукою успіху в цій справі, на наше глибоке переконання, має стати освітня й просвітницька діяльність за активного й дієвого державного сприяння. Для продуктивної інформаційної взаємодії вкрай необхідна належна освіченість користувачів та їх поінформованість щодо відповідних прав та обов'язків. Провідною ідеєю сучасної інформаційно-технологічної освіти є гуманізм, усвідомлення того, що головною метою розвитку суспільства є людина, ії фізичне, інтелектуальне, духовне й психологічне зростання, котре визначає її потреби, пріоритети, інтереси й, зрештою, сенс життя.

Отже, змінюючи свідомість окремого індивіда, освіта до певної міри модифікує суспільну свідомість, тому освіта, і в цьому полягає іiі неминуща цінність, є важливим атрибутом набуття суспільством свого нового стану, де відбувається формування нової якості свідомості, як індивідуальної, групової, так і суспільної загалом.

В інформаційному суспільстві особлива роль освіти полягає в навчанні не лише використання інформаційних технологій і кіберпростору, але й громадянських та морально-етичних засад життєдіяльності. Освітня система як суспільна інституція з формування «людини соціальної» має істотно посприяти вирішенню завдання прищеплення суб'єктам інформаційних відносин розуміння й потреби дотримуватися норм інформаційної етики, а також виховання у них їх застосування.

Крім того, на систему освіти покладається завдання, щоби всі суб'єкти суспільних відносин були поінформовані стосовно основ чинного законодавства, їхніх прав і обов'язків, проблем, із якими стикається інформаційне суспільство та шляхів їх подолання. Отже, у процесі навчання, виховання та всебічного розвитку особистості однією з головних освітніх функцій є інформування, пояснення правових і моральноетичних аспектів забезпечення інформаційної та кібернетичної безпеки на індивідуальному рівні.

Система освіти для формування повноцінного інформаційного суспільства має домагатися того, щоби кожен його член усвідомив свою роль у загальному інформаційно-безпековому процесі, був спроможним розуміти характер впливу технологій на життєдіяльність суспільства, зіставляти свою поведінку із загальноприйнятими морально-етичними цінностями. Актуальність цих тверджень підтверджується положеннями «Етичного кодексу інформаційного суспільства» ЮНЕСКО, де правове регулювання й самоконтроль є запорукою належного регулювання інформаційної взаємодії [5].

Отже, на мікрорівні (індивідуальному) соціальних інформаційно-безпекових заходів передбачено формування у кожного індивіда (зокрема, із застосуванням спеціалізованих форм підготовки, тренінгів за спеціальними методиками) під час використання ним інформаційних технологій і кіберпростору участі в інформаційних відносинах особистісних настанов, моделей поведінки, сукупність яких складає систему морально-етичних спонук людини, котрі регулюють ії діяльність в інформаційному, кібернетичному середовищі.

На соціальні заходи забезпечення інформаційної безпеки перших двох із проаналізованих рівнів впливають переважно зовнішні чинники, діяльність соціальних інституцій та інших сторонніх суб’єктів тощо. Натомість успіх «мікрорівневих» заходів зумовлюється насамперед діями самої людини.

Важливою умовою створення дієвої системи кібербезпеки загалом та інформаційно-психологічної безпеки кожної людини зокрема є суб' єктивний чинник, тобто рівень усвідомлення особою наявних викликів і загроз, іiі бажання існувати у безпечному інформаційному й кібернетичному середовищі. При цьому правильним є віднесення досягнення належного рівня культури інформаційних відносин до національних цілей в інформаційній сфері [6, с. 386]. Кожен має особисто прагнути до оволодіння інформаційно-безпековими навичками, бажати навчитися забезпечувати у доступний йому спосіб інформаційну безпеку. Іншими словами, соціальна активність кожного індивіда полягає передусім, на нашу думку, в усвідомленні власних прав і обов’язків, у втіленні засад інформаційної етики як підгрунтя кібернетичної безпеки.

Таким чином, соціальні інформаційно-безпекові заходи - це ухвалена й підтримувана особою, колективом, суспільством і державою багаторівнева система технологій, спрямована на створення специфічного механізму регуляції, котрий визначає відповідну морально-етичну поведінку людини у процесі користування інформаційними технологіями та кіберпростором і взаємодії в цьому середовищі. Ці заходи стверджують і зміцнюють усталені правові приписи й морально-етичні настанови щодо інформаційної безпеки. Між 
тим вони є суспільним рушієм популяризації загальнонаукової теорії інформаційної безпеки, котра нині формується в рамках світової наукової думки. Крім того, вони зумовлюють гуманістичну спрямованість зазначеної ідеї, а це, зрештою, має привести до кардинального прогресу в розумінні сутності та особливостей феномена інформаційної та кібернетичної безпеки.

Трансформації, які відбулися у світобаченні людини на зламі тисячоліть, зумовили різке зростання вагомості ціннісної складової частини у глобальній безпековій системі. Це об'єктивно підтверджує постулат, що будь-яка теорія безпеки сприймається суспільством лише тоді, коли вона має гуманістичну спрямованість, відповідає інтересам людини, поважає і1і права і свободи, зокрема інформаційні. Як правильно резюмується, основні інформаційні права і свободи, закріплені в Конституції України, є основою та орієнтиром формування інформаційного суспільства [7, с. 150; 8]. Сучасна безпекова наука вбирає у себе все більше складових частин, зокрема соціальних, економічних, політичних, психологічних. Це надає їй значно більшої динамічності, гнучкості, здатності відповідати конкретним викликам певного історичного періоду.

Ми підтримуємо думку вчених, які науково доводять виникнення нових складових часттин інституту інформаційного права, зокрема виникнення підгалузі інформаційної безпеки [9], при цьому вважаємо, що розвиток теоретичних напрацювань у сфері кібербезпеки сприятиме утвердженню інформаційного права як окремого інституту права та розвитку вітчизняної правничої науки загалом.

Висновки 3 дослідження і перспективи подальших розвідок у цьому напрямі. Сучасний стан формування загальної теорії кібербезпеки характеризується намаганням врахувати останні фундаментальні напрацювання у цій галузі та вирішити чималу кількість проблемних питань. Останні, як убачається, зумовлені низкою об'єктивних та суб'єктивних чинників.

Це, по-перше, складний, комплексний характер зазначених проблем, вирішення яких потребує інтегрованих зусиль різних наукових галузей. По-друге, серед чинників, які впливають на стан інформаційної безпеки, дуже багато суб'єктивних. Крім того, це величезне розмаїття джерел і причин викликів та загроз інформаційній безпеці.

Результатом розвитку загальної теорії кібербезпеки має стати науково-теоретичне утворення, відповідним чином зорієнтоване у предметному й проблемному сенсі. Проте не слід вважати їі певною інтегрованою концепцією, котра вивчає геть усі аспекти інформаційної безпеки, які є предметом вивчення різних наукових галузей. Убачається, що штучне об’єднання цих численних і різнопланових аспектів не лише недоцільне, але й узагалі неможливе.

Втім, для чіткого з’ясування місця загальнонаукової теорії кібернетичної безпеки, яка перебуває на етапі формування, потрібно виявити ії взаємозв'язок з іншими спеціальними безпековими теоріями, а також iз технічними, природничими й суспільними науками, оскільки питання інформаційної безпеки, як зазначалося вище, розглядаються прямо чи опосередковано усіма науковими галузями. Таким чином, можемо стверджувати, що, методологічно підтримуючи усі дослідження безпекової проблематики в усіх наукових галузях, загальнонаукова теорія кібербезпеки пов'язана 3 кожною з них. При цьому слід підкреслити, що йдеться про універсальний цілісний феномен, котрий розкриває основні засади забезпечення інформаційної безпеки у різних сферах життєдіяльності.

Теорія кібернетичної безпеки з точки зору свого теоретичного статусу зорієнтована на розгляд комплексних наукових проблем, які є суміжними для різних наук. Це, звісно, зближує нову теорію 3 подібними. Вона уявляється таким напрямом наукового пошуку, котрий яскраво унаочнює умовність поділу на наукові галузі, єдність і цілісність Всесвіту, оскільки на системній основі забезпечує перетин прикладних дисциплін. Отже, теорія інформаційної та кібернетичної безпеки об'єднує прикладні моменти різних наук для вивчення сутності, змісту, форм, засобів і методів іiі забезпечення, перетворюється на методологічну базу та початковий пункт подальших розробок окремих, спеціалізованих інформаційно-безпекових концепцій.

Одним із найважливіших завдань інформаційної етики, спрямованим на сприяння гуманізації суспільства, є домагання того, щоби захист прав і свобод людини став головним пріоритетом у застосуванні інформаційних технологій і використанні кіберпростору. Важливість такого завдання підтверджується, зокрема, тим, що у положеннях Декларації прав людини Організації Об'єднаних Націй принципи інформаційної етики знайшли своє відображення. Двоєдиною умовою виконання цього завдання є створення у глобальних інформаційних мережах якомога більшого легітимного контенту, а також забезпечення доступності інформації, відповідних технологій, кіберпростору для якнайширшого загалу.

Щодо подальшого наукового пошуку в напрямі розвитку проблематики, яка стала предметом розгляду в цій праці, то він, на наш погляд, може здійснюватися в межах досліджень у галузі інформаційної та кібернетичної безпеки, еволюції інформаційного та кіберпростору, створення концепцій сталого суспільного прогресу.

\section{Список використаних джерел:}

1. Конвенція про захист прав людини і основоположних свобод. Редакція від 2 жовтня 2013 року. URL: https://zakon.rada.gov.ua/laws/show/995_004\#Text.

2. Миролюбенко Г. Місце та роль спільнот в інтернет-комунікації. Гілея. Історичні науки. Філософські науки. Політичні науки. 2011. Вип. 45 (№ 3). С. 311-318. 
3. Филиппова Л., Зеленецкий В. Компьютерная этика. Морально-этические и правовые нормы для пользователей компьютерных сетей : учебное пособие. Харьков : Кроссроуд, 2006. 266 с.

4. Froehlich T.J. Survey and analysis of legal and ethical issues for library and information services, UNESCO Report (Contract № 401.723.4), for the International Federation of Library Associations. IFLA Professional Series. Munich : G.K. Saur, 1997.

5. In search of a code of global information ethics: the road travelled and new horizons. Rafael Capurro and Johannes B. Britz. URL: http://www.capurro.de/britz.html.

6. Ткачук Т. Правове забезпечення інформаційної безпеки в умовах євроінтеграції України : дис. ... докт. юрид. наук : спец. 12.00.07. Ужгород, 2019. 487 с.

7. Ткачук Н. Інформаційні права і свободи людини та громадянина як основа формування інформаційного суспільства. Науковий вісник публічного та приватного права. 2017. Вип. 6. Т. 2. С. $147-151$.

8. Ткачук Н. Інформаційні права і свободи людини і громадянина в Україні: визначення термінів, співвідношення понять. Інформація і право. 2018. № 2 (25). С. 17-30.

9. Довгань О., Ткачук Т. Правове забезпечення інформаційної безпеки держави як підгалузь інформаційного права: теоретичний дискурс. Інформащія і право. 2018. № 2 (25). С. 73-85. 
УДК 342.951

DOI https://doi.org/10.32836/2521-6473.2020-4.11

\author{
T. І. Шинкар, кандидат юридичних наук, \\ суддя Восьмого апеляційного адміністративного суду
}

\title{
СУДОВИЙ ЗАХИСТ ПРАВА НА ДОСТУП ДО ПУБЛІЧНОЇ ІНФОРМАЦІЇ
}

У статті досліджено роль та значення судового захисту в системі гарантування права на доступ до публічної інформації. При иъьму зазначено, щзо сама ідея захисту основних прав та свобод людини з визначенням ролі в иьому судової влади набула активного розвитку після закінчення Другої світової війни. Зокрема, право на судовий захист прав людини було закріплене у статті 8 Загальної декларації прав людини від 10 грудня 1948 року та Міжнародному пакті про громадянські та політичні права від 16 грудня 1966 року. Аналіз судової практики за останні роки показує, щзо порушення норм Закону України «Про доступ до публічної інформацїі» виявляється під час обмеження доступу до певного виду публічної інформації. Наведено позицію Вищого адміністративного суду України, що викладена у п. 5.5 Постанови пленуму «Про практику застосування адміністративними судами законодавства про доступ до публічної інформачіï» від 29 вересня 2016 року № 10, згідно з якою відмова в наданні інформації є обтрунтованою тільки тоді, коли розпорядник у листі конкретизує, якому саме інтересу загрожує розголошення запитуваної інформації, та всебічно обтрунтовує істотність шкоди ичим інтересом від ї̈ розголошення. Крім того, проаналізовано практику Європейського суду з прав людини щьодо порушення права доступу до інформації. Зроблено загальний висновок про те, щзо судовий захист є основною гарантією права людини на доступ до публічної інформації та посідає важливе місце в системі гарантій реалізації конституиійних прав людини і громадянина.

Ключові слова: публічна інформація, судовий захист, адміністративне судочинство, практика Європейського суду з прав людини.

\section{T. I. Shynkar. Judicial protection of the right to access public information}

The article examines the role and importance of judicial protection in the system of guaranteeing the right to access public information. It is pointed out that the very idea of protecting fundamental human rights and freedoms with the definition of the role of the judiciary has been actively developed since the end of World War II. In particular, the right to judicial protection of human rights was enshrined in Article 8 of the Universal Declaration of Human Rights of 10 December 1948 and the International Covenant on Civil and Political Rights of 16 December 1966.

It is noted that the analysis of judicial practice in recent years shows that violations of the Law of Ukraine "On Access to Public Information" is manifested by restricting access to certain types of public information, while case law clearly indicates what are the most common mistakes in obtaining information, which makes it impossible to further appeal or makes it hopeless. First of all, it is the text of the request for access to public information. The position of the Supreme Administrative Court of Ukraine, set out in paragraph 5.5 of the resolution of the plenum of 29.09.2016 №10 "On the practice of application by administrative courts of legislation on access to public information", according to which refusal to provide information is justified only when the administrator specifies in the letter which interest is threatened by the disclosure of the requested information and fully justifies the material harm of this interest from its disclosure. In addition, the case law of the European Court of Human Rights on the violation of the right of access to information is analyzed. The general conclusion is made that judicial protection is the main guarantee of the human right to access public information and occupies an important place in the system of guarantees for the realization of constitutional human and civil rights. Rights.

Key words: public information, judicial protection, administrative proceedings, case law of the European Court of Human

Постановка проблеми. Демократичний поступ України неможливий без активної участі громадян у процесі формування й прийняття рішень органами публічної влади та без контролю за їхньою діяльністю з боку суспільства, що передбачає отримання кожним його членом достовірної і повної інформації про цю діяльність. Право кожної людини на інформацію, що в сучасному інформаційному суспільстві є одним із ключових конституційних прав людини та громадянина, закріплено у фундаментальних міжнародних актах, а саме Конвенції про захист прав і основоположних свобод людини та Міжнародному пакті про громадянські і політичні права. У нашій державі право на інформацію також закріплене Конституцією України. Проте важливою та актуальною проблемою на сучасному етапі є забезпечення права людини на доступ до публічної інформації, оскільки реальна можливість отримання цієї інформації є одним із головних засобів, який допомагає здійснювати громадянський контроль за діями влади.

Аналіз останніх досліджень і публікацій. Питання, пов’язані з поняттям інформації, правом на доступ до публічної інформації, механізмом доступу до публічної інформації, досліджували у своїх наукових працях

(C) T. I. Шинкар, 2020 
О. Андрійко, Н. Власенко, О. Каплій, Н. Костова, Н. Каменська, Д. Лилак, О. Майстренко, О. Нестеренко, Є. Петров, С. Погребняк, В. Порада, Л. Рудник, С. Стасюк, С. Тептюк, Т. Чубарук та інші вчені.

Водночас актуальним як у практичному, так і в теоретичному аспектах $є$ наукове дослідження гарантій права на доступ до публічної інформації, вивчення проблемних питань щодо порядку його реалізації, зокрема практики судового захисту цього права.

Мета статті полягає у з'ясуванні ролі судового захисту та, зокрема, практики Європейського суду 3 прав людини в системі гарантування права на доступ до публічної інформації.

Виклад основного матеріалу. 3 прийняттям у 2011 році Закону України «Про доступ до публічної інформації» в національне законодавство було введене раніше відсутнє в ньому поняття «публічна інформація», а також певною мірою по-новому почали регулюватися питання права кожного на доступ до інформації, що є у сфері діяльності суб'єктів владних повноважень, а також питання гарантій зазначеного права, основною з яких є судовий захист.

Ідея захисту основних прав та свобод людини з визначенням ролі в цьому судової влади набула активного розвитку після закінчення Другої світової війни. Резолюцією 217А (IIT) Генеральної асамблеї ООН 10 грудня 1948 року прийнято Загальну декларацію прав людини, у статті 8 якої зазначено, що кожна людина має право на ефективне поновлення у правах компетентними національними судами в разі порушення іiі основних прав, наданих їй конституцією або законом [1].

Подальше закріплення права на судовий захист на міжнародному рівні відбулося 16 грудня 1966 року, коли резолюцією Генеральної Асамблеї ООН 2200А (XXI) був прийнятий Міжнародний пакт про громадянські та політичні права, що передбачав конкретні дії з боку держав-учасниць щодо закріплення права на судовий захист. Так, у частині 3 статті 2 цього Пакту зазначено, що держава повинна гарантувати кожному, чиї права і свободи порушено, ефективний засіб правового захисту, навіть якщо це порушення було вчинене особами, які діяли як особи офіційні, i таке право має гарантуватися судом або будь-яким іншим компетентним органом, передбаченим правовою системою держави. Відповідно до частини 1 статті 14 цього документа, всі особи є рівними перед судами і трибуналами. Кожен має право під час визначення його прав та обов'язків у будь-якому цивільному процесі на справедливий і публічний розгляд справи компетентним, незалежним і безстороннім судом, створеним на підставі закону [2].

Разом з новою Конституцією України 1996 року право на судовий захист набуло значення конституційного права людини та громадянина. Зокрема, стаття 55 Основного Закону встановлює, що права і свободи людини та громадянина захищаються судом. Кожному гарантовано право на оскарження в суді рішень, дій чи бездіяльності органів державної влади, органів місцевого самоврядування, посадових і службових осіб [3].

У Постанові Пленуму Верховного Суду України «Про застосування Конституції України при здійсненні правосуддя» від 1 листопада 1996 року № 9 зазначено, що конституційні права та свободи людини і громадянина $є$ безпосередньо чинними. Вони визначають цілі й зміст законів та інших нормативно-правових актів, зміст і спрямованість діяльності органів законодавчої та виконавчої влади, органів місцевого самоврядування і забезпечені захистом правосуддя [4].

Згідно з пунктами 1, 2 Постанови Пленуму Верховного Суду України «Про посилення судового захисту прав і свобод людини та громадянина» від 30 травня 1997 року № 7, вся діяльність судів має підпорядковуватися захисту цих прав та свобод [5, с. 2].

Відповідно, закріплення на конституційному і законодавчому рівні права людини на доступ до публічної інформації передбачає його судовий захист. Специфіка судового захисту права людини на доступ до публічної інформації полягає в тому, що людина робить власний вибір, звертатися чи не звертатися до суду за захистом свого інформаційного права, тобто судова гарантія за загальним правилом починається з моменту прийняття судом до розгляду відповідного звернення про порушення права людини [6, с. 114-115].

Аналіз судової практики останніх років показує, що порушення норм Закону України «Про доступ до публічної інформації» виявляється під час обмеження доступу до певного виду публічної інформації, при цьому обов'язково проводиться перевірка іiі на відповідність трьом вимогам, зазначеним у частині 2 статті 6 цього Закону. Проте судова практика чітко вказує на найтиповіші помилки, які трапляються під час отримання інформації, що унеможливлює подальше оскарження або робить його безперспективним. Насамперед це текст запиту на доступ до публічної інформації. Суди звертають увагу на те, що для того, щоби мати можливість у подальшому оскаржити бездіяльність розпорядника інформації, запит має містити таке:

1) чітке визначення витребуваної інформації, яка задокументована або іншим чином зафіксована;

2) чітка вказівка на те, що запит на доступ до публічної інформації подається саме відповідно зо Закону України «Про доступ до публічної інформації», а не за іншою процедурою;

3) визначення, до якого саме розпорядника інформації адресується запит [7].

Варто зазначити, що, згідно з висновком Вищого адміністративного суду України, відмова в наданні інформації є обгрунтованою тільки в тому випадку, коли розпорядник у листі конкретизує, якому саме інтересу загрожує розголошення запитуваної інформації, та всебічно обгрунтовує істотність шкоди цьому інтер- 
есу від ії розголошення (підпункт 5.5 Постанови пленуму ВАСУ «Про практику застосування адміністративними судами законодавства про доступ до публічної інформації» від 29 вересня 2016 року № 10). Водночас на практиці обмеження доступу до публічної інформації відбувається за наявності таких системних порушень 3 боку владних структур:

- відмова у задоволенні запиту, підставою для якої є віднесення запитуваної інформації до інформації з обмеженим доступом;

- необгрунтоване ненадання інформації щодо володіння, користування чи розпорядження державним або комунальним майном та бюджетними коштами;

- обмеження доступу до частини інформації та надання iï у неповному вигляді;

- пояснення відмови у наданні інформації запитувачу відсутністю зазначеної ним мети ії отримання, що може супроводжуватись пропозицією ознайомлення з такою інформацією у приміщенні розпорядника;

- надання запитувачу відповіді, що суперечить сутності запиту;

- неправомірна аргументація відмови у наданні інформації непоширенням положень Закону України «Про доступ до публічної інформації» на діяльність державних та комунальних підприємств та установ, незважаючи на те, що вони є розпорядниками суспільно необхідної інформації та інформації щодо розпорядження бюджетними коштами [7].

Загалом аналіз практики подачі та розгляду скарг щодо порушення права на доступ до публічної інформації засвідчує, що наявність правопорушень у цій сфері пов'язана як з неточністю окремих положень Закону України «Про доступ до публічної інформації», так і з намаганням розпорядників інформації відшукати певні «правові» способи обмеження доступу до публічної інформації.

У цьому контексті варто виділити статтю 23 Закону України «Про доступ до публічної інформації», що надає право оскаржувати рішення, дії чи бездіяльність розпорядників інформації у разі:

- відмови в задоволенні запиту на інформацію;

- відстрочки задоволення запиту на інформацію;

- ненадання відповіді на запит на інформацію;

- надання недостовірної або неповної інформації;

- несвоєчасного надання інформації;

- невиконання розпорядниками обов'язку оприлюднювати інформацію;

- інших рішень, дій чи бездіяльності розпорядників інформації, що порушують законні права та інтереси запитувача [8].

Аналіз судової практики показує, що за умови надання позивачем належних доказів порушення його прав, а з боку відповідача - недостатньої аргументації правомірності його дій, суди переважно задовольняють позовні вимоги. Водночас повна відмова судом у задоволенні позовних вимог наявна в разі непоширення дії Закону «Про доступ до публічної інформації» на оспорювані відносини, звернення запитувача інформації до неналежного розпорядника або в разі відсутності належних доказів протиправності дій відповідача.

При цьому, на думку фахівців, проблемними сьогодні залишаються питання, пов'язані з протиправним віднесенням інформації до конфіденційної та службової, а також з неможливістю відшкодування майнової і моральної шкоди. Крім того, трапляються випадки неоднакового розуміння судами належності доказу надання відповіді розпорядником та механізму забезпечення доступу до інформації [7].

Доречно зазначити, що судовий захист права на доступ до публічної інформації в Україні не обмежений системою національних судів. Нагадаємо, що стаття 55 Конституції України передбачає право кожного після використання всіх національних засобів правового захисту звертатися за захистом своїх прав і свобод до відповідних міжнародних судових установ чи відповідних органів міжнародних організацій, членом яких є Україна. До зазначених міжнародних судових установ належить насамперед Європейський суд з прав людини (далі - ЄСПЛ).

Нагадаємо, що Україна як член Ради Європи у 1977 році ратифікувала Європейську конвенцію про захист прав людини й основоположних свобод від 4 листопада 1950 року (далі - Конвенція) [9]. Як зазначив ЄСПЛ, «Конвенція має на меті захист не теоретичних чи ілюзорних, а конкретних і дієвих прав». Сьогодні вона $\epsilon$ частиною законодавства України, що позитивно вплинуло на якісні зміни у правовому регулюванні відносин між державою та громадянином, пов'язані безпосередньо з рішеннями ЄСПЛ, які, відповідно до Конвенції і Конституції України, також стають частиною національного законодавства.

Конвенцією передбачено якісно нову методологічну основу впливу діяльності ЄСПЛ на правову систему України. Це зумовлено передачею до ЄСПЛ здебільшого заяв, у яких оскаржуються дії насамперед органів виконавчої влади в межах здійснення останніми адміністративних функцій. Якщо раніше регулювання діяльності органів виконавчої влади традиційно відбувалось національним правом з огляду на захист інтересів держави, то положення Конвенції спрямовані на захист передусім прав людини від неправомірних дій державних органів [6, с. 116].

Першим рішенням ЄСПЛ з питань доступу до інформації, яка перебуває в розпорядженні держави, було рішення у справі «Леандер проти Швеції» 1987 року. У ньому сформульовано тогочасний підхід Суду до питання доступу до архівів спецслужб з інформацією про особу пана Леандера, який у своєму зверненні 
оскаржував порушення статті 8 та статті 10 Конвенції. В цьому рішенні ЄСПЛ уперше була сформульована його позиція щодо отримання заявником інформації, що перебуває в державних органах. Відповідно до цієї позиції, положення статті 10 про «свободу одержувати інформацію» Конвенції загалом містить заборону урядові здійснювати обмеження будь-кого в одержанні ним інформації, яку інші хотіли б або були б не проти йому передати [10, с. 6-7].

Одним із фундаментальних рішень ЄСПЛ щодо порушення права доступу до інформації вважається рішення у справі Угорської спілки громадянських свобод проти Республіки Угорщина. Заявник стверджував, що рішення національних судів Угорщини про відмову йому в доступі до інформації стосовно парламентської скарги, яка перебувала на розгляді в Конституційному суді, є порушенням його права на доступ до інформації, що становить суспільний інтерес.

В рішенні у цій справі Судом, зокрема, було зазначено, що стаття 10 Конвенції не дає змогу вводити умовні обмеження, які вважаються формою непрямої цензури, якщо вони створюють перешкоди владним структурам у зборі інформації. При цьому до функцій преси належить не лише збір інформації, але й проведення громадських обговорень, що є невід'ємною частиною свободи преси. Проте здійснення цих функцій належить громадським організаціям, які також роблять важливий внесок в обговорення та вирішення громадських справ. Отже, ССПЛ визначив, що, оскільки заявником у зазначеній справі виступило громадське об'єднання, яке стало учасником судового процесу з питань прав людини, зокрема, задля захисту свободи інформації, воно, як і преса, може долучатись до захисту демократії.

Таким чином, у своєму рішенні ЄСПЛ здійснює доволі широке тлумачення права на доступ до інформації, трактуючи його як таке, що має на меті заборону на обмеження державою доступу особи до інформації, яку інші хочуть чи можуть захотіти отримати. У висновках в цій справі Судом було, зокрема, зазначено, що справа стосується саме втручання державних органів на основі цензурної сили монополії на інформацію, що є неприпустимим, оскільки обов'язками держави відносно преси та громадських об'єднань як «сторожових псів демократії» належить також знищення бар'єрів для виконання пресою покладених на неї функцій $[10$, c. 132$]$.

Отже, розглянуте рішення встановлює правило, згідно з яким обов'язком державних органів, зокрема парламенту та його членів, а також судів $є$ опублікування інформації, розпорядниками якої вони є відповідно до закону, особливо інформації, необхідної для проведення громадських обговорень суспільно значущих питань. Користування правом на доступ до інформації дає громадськості можливість впливати на прийняття рішень державного значення, а також сприяє захисту прав громадян та боротьбі з корупцією.

У рішенні ССПЛ у справі «Герцегфалві проти Австрії» 1992 року було визнано порушення права на одержання інформації, з посиланням на відсутність у національному законодавстві будь-якого положення, що передбачало б відмову в доступі до друкованих матеріалів, радіо й телебачення щодо особи, яка примусово утримується у психіатричному закладі. Справа ««Оупен дор» і «ДабМн Уел Вумен» проти Ірландії»»» (1992 рік) стосувалася права передавати інформацію та права доступу до інформації щодо можливостей зробити аборт за кордоном. Заявником у цій справі оскаржувалося судове рішення, яким двом компаніям було заборонено надавати таку інформацію вагітним жінкам під час консультування. ССПЛ визнав наявність порушення статті 10 з урахуванням низки чинників, а саме загального характеру цієї заборони, можливості одержання такої інформації з інших джерел та відсутності будь-якої заборони для жінок виїздити за кордон фактично задля проведення операції [6, с. 121].

Крім того, ССПЛ було визнано порушення статті 10 у справі «Кіпр проти Туреччини» 2001 року, в якій органами влади Туреччини було запроваджено надто жорсткі умови цензури шкільних підручників, що призначалися для початкових шкіл греків-кіпріотів у північній частині Кіпру [11].

Варто зазначити, що 23 березня 2020 року ЄСПЛ ухвалив рішення на користь заявника у справі «Центр демократії та верховенства права проти України». Судом визнано порушення статті 10 Конвенції через відмову у доступі до інформації про освіту та трудову діяльність політичних лідерів, що міститься в їхніх автобіографіях. Це одна з найважливіших судових справ, у якій у Свропейському суді було доведено, що доступ до публічної інформації повинен надаватися запитувачам. Окрім того, очікується рішення по справі «Лещенко проти України», у якій оскаржується незаконність відмови у доступі до інформації про умови передачі Віктору Януковичу землі у Межигір’ї [12].

Висновки з дослідження і перспективи подальших розвідок у цьому напрямі. Таким чином, судовий захист є основною гарантією права людини на доступ до публічної інформації, якій належить ключова роль у системі гарантій реалізації конституційних прав особи, оскільки саме у процесі вирішення спорів у суді виявляються найсуттєвіші законодавчі недоліки та суперечності. При цьому до способів судового захисту як важливої гарантії права людини на доступ до публічної інформації потрібно віднести як безпосередній судовий захист права конкретної людини на інформацію, що здійснюється системою адміністративних судів на чолі з Верховним Судом України під час розгляду та вирішення ними відповідних судових справ, так і судовий захист конституційного права людини на інформацію, що здійснюється Свропейським судом з прав людини, рішення якого використовується як орієнтир для подальшої національної судової практики різних держав. 


\section{Список використаних джерел:}

1. Загальна декларація прав людини. URL: https://zakon.rada.gov.ua/laws/show/995 015\#Text.

2. Міжнародний пакт про громадянські та політичні права. URL: https://zakon.rada.gov.ua/laws/ show/995 043\#Text.

3. Конституція України від 28 червня 1996 року. Відомості Верховної Ради Украӥни. 1996. № 30. СТ. 141.

4. Про застосування Конституції України при здійсненні правосуддя : Постанова Пленуму Верховного Суду України від 1 листопада 1996 року. URL: https://zakon.rada.gov.ua/laws/show/v0009700-96\#Text.

5. Про посилення судового захисту прав і свобод людини і громадянина : Постанова Пленуму Верховного Суду України від 30 травня 1997 року. Вісник Верховного Суду Украӥни. 1997. № 2. С. 2-4.

6. Тептюк С. Конституційне право на доступ до публічної інформації: проблеми законодавчого регулювання та судового захисту : дис. ... канд. юрид. наук : спец. 12.00.02 «Конституційне право; муніципальне право» ; Інститут держави і права ім. В.М. Корецького НАН України. Київ, 2018. 215 c. URL: idpnan.org.ua.

7. Полотнянко О. Захист права на доступ до інформації- виклики сьогодення. URL: https://unba.org.ua/ publications/print/5376-zahist-prava-na-dostup-do-informacii-vikliki-s-ogodennya.html.

8. Про доступ до публічної інформації : Закон України від 13 січня 2011 року № 2939-VI. URL: https://zakon.rada.gov.ua/laws/show/2939-17.

9. Конвенція про захист прав людини і основоположних свобод. URL: https://zakon.rada.gov.ua/laws/ show/995 004\#Text (дата звернення: 29.10.2020).

10. Рішення Свропейського суду з прав людини щодо доступу до інформації / заг. ред. Т. Шевченко, I. Розкладай. Київ : Москаленко О.М., 2014. 200 с.

11. Практика Свропейського суду з прав людини. Рішення. Коментарі. URL: http://eurocourt.in.ua (дата звернення: 29.10.2020).

12. Лайфхаки від ЦЕДЕМ: як виграти в ЄСПЛ справу 3 доступу до інформації. URL: https://dostup.pravda.com.ua/digest/publications/laifkhaky-vid-tsedem-iak-vyhraty-v-yespl-spravu-z-dostupu-doinformatsii (дата звернення: 29.10.2020). 
УДК 347.195 .1

DOI https://doi.org/10.32836/2521-6473.2020-4.12

\author{
О. О. Біляєв, асистент кафедри цивільного права № 1 \\ Національного юридичного університету імені Ярослава Мудрого
}

\title{
ОСОБЛИВОСТІ ВІДПОВІДАЛЬНОСТІ У СФЕРІ СПОРТУ
}

Статтю присвячено розгляду правопорушень у сфері спорту та особливостей притягнення до відповідальності учасників спортивних відносин, а саме спортсменів та спортивних організацій. Встановлено види та специфіку притягнення до відповідальності у сфері спорту.

Дослідження відповідальності у спорті відбувається крізь призму юридичної відповідальності, яка розуміється як правовідносини між суб 'єктом, який порушив приписи правової норми, з одного боку, і державою в особі його органів або інших організачій, уповноважених визначити стосовно порушника міру відповідальності на підставі правових норм, з іншого боку, а також ичивільно-правової відповідальності спортивних організачій як юридичних осіб за власні дії та дії спортсменів, щзо перебувають у складі такої організаиії. Відповідальність юридичної особи за дї ї̈ органів, а також учасників (засновників) виникає на загальних підставах юридичної відповідальності. Однак якщо изі дії вчинені органом з порушенням компетениіі, то юридична особа не може бути визнана відповідальною за дії свого органу. Дії зазначених осіб від імені спортивної організації в ї̈ інтересах (щзо полягають у досягненні спортивного результату), але зі спотворенням волі останньої, яка може бути спрямована на досягнення результату лише правомірними засобами, створюють підстави для покладання відповідальності на саму організацію. Відповідальність може визначатися як механізм перерозподілу витрат, заснований на ідеї справедливого відшкодування: витрати того, чиє право порушено, переносяться на того, з чиєї вини сталося порушення.

У спеціалізованій літературі дедалі частіше зустрічаються терміни «спортивна відповідальність», «спортивно-змагальна відповідальність», «спортивні санкиї», підстави виникнення, механізми та наслідки застосування яких відмінні від установлених загальним законодавством.

Аналіз видів спортивної відповідальності дає змогу виділяти основні критерії їі самостійності, які можуть впливати на виділення спортивної відповідальності у самостійний вид відповідальності юридичної.

Ключові слова: спорт, відповідальність, юридична особа, спортивна організація, спортивні правовідносини.

\section{O. O. Biliaiev. Features of responsibility in the field of sports}

The article is devoted to the consideration of offenses in the field of sports and the peculiarities of bringing to justice the participants of sports relations: athletes and sports organizations. The types and specifics of prosecution in the field of sports are established.

The study of liability in sport is through the prism of legal liability, which is understood as a legal relationship between the subject who violated the provisions of the rule of law, on the one hand, and the state represented by its bodies or other organizations authorized to determine the degree of liability. on the other hand, as well as civil liability of sports organizations as legal entities for their own actions and the actions of athletes who are part of such an organization. The liability of a legal entity for the actions of its bodies, as well as participants (founders) arises on the general grounds of legal liability. However, if these actions are committed by a body in violation of its competence, the legal entity cannot be held liable for the actions of its body. The actions of these persons on behalf of the sports organization, in its interests (consisting in achieving a sports result), but with the distortion of the will of the latter, which can be aimed at achieving the result only by lawful means, create grounds for imposing responsibility on the organization. Liability can be defined as a mechanism for redistributing costs based on the idea of fair reimbursement: the costs of the person whose rights have been violated are transferred to the person whose fault the violation occurred.

In the specialized literature the term "sports responsibility”, "sports-competitive responsibility”, "sports sanctions", the bases of occurrence, mechanisms and consequences of application of which differ from established by the general legislation more and more often meet.

The analysis of types of sports responsibility allows allocating the basic criteria of its independence which can float on allocation of sports responsibility in an independent type of legal responsibility.

Key words: sport, responsibility, legal entity, sports organization, sports legal relations.

Постановка проблеми. Разом із досягненнями сфера спорту рясніє негативними прикладами. Комерціалізація цієї сфери й бажання досягнення спортивного результату незалежно від використовуваних засобів, що впливають на репутацію як самої спортивної організації, іiі засновників (учасників), так і іноді представленої держави, призвели до появи таких проблем, як вживання заборонених у спорті засобів і методів (допінг), договірні матчі, спекуляції з вхідними квитками, збільшення спортивного травматизму.

У зв’язку з цим особливої актуальності набуває розроблення правового механізму протидії цим явищам. Насамперед це стосується вдосконалення механізму відповідальності у сфері спорту. Тому метою

(C) О. О. Білясв, 2020 
статті $\epsilon$ розгляд правопорушень у сфері спорту та особливостей притягнення до відповідальності учасників спортивних відносин.

Аналіз останніх досліджень і публікацій. Специфіку юридичної відповідальності в контексті характеристики видів правовідносин розглядала Р.О. Халфіна [1, с. 320-344]. Питання про специфіку юридичної відповідальності в галузі спорту у своїх роботах досліджували такі вчені, як С.В. Алексєєв, А.Е. Базикін [2, с. 108-113], О.Ю. Краснова [3, с. 124-128], І.М. Аміров [4, с. 28-32], А.В. Балаганіна [5, с. 32-36], Н.А. Овчиннікова [6, с. 111-115], М.А. Прокопець [7, с. 131-136]. В Україні дослідженню одного з аспектів цієї проблематики присвячена значна частина дисертаційного дослідження М.О. Ткалича [8, с. 12-13], 3вертається увага на деякі аспекти цивільної відповідальності у сфері спорту в дисертаційному дослідженні М.А. Журби [9], наукових роботах О.В. Облакової [10], М.А. Тіхонової [11].

Виклад основного матеріалу. Спеціальне законодавство, що регулює питання відповідальності спортивних організацій та інших суб'єктів у сфері спорту, нині відсутнє. Закон України «Про фізичну культуру і спорт» [12] обмежується ст. 54 про цивільно-правову, дисциплінарну, адміністративну або кримінальну відповідальність осіб, винних у порушенні законодавства у сфері фізичної культури відповідно до закону. Деякою мірою це положення розвивається Законом України «Про особливості забезпечення громадського порядку та громадської безпеки у зв'язку з підготовкою та проведенням футбольних матчів» [13], прийнятим внаслідок одержання Україною права на проведення чемпіонату Свропи з футболу у 2012 році. Одними із суб'єктів відповідальності, виділених у цьому Законі, є футбольні клуби, зобов'язані завчасно попереджати органи МВС про організований виїзд глядачів із зазначенням їх кількості, виду транспортного засобу, часу виїзду та приїзду, а за невиконання зазначених вимог до них можуть бути застосовані фінансові санкції. Фактично йдеться про те, що за бажання футбольного клубу мати глядацьку підтримку під час матчів у гостях задля забезпечення найбільшого рівня безпеки органами правопорядку вся організація поїздок лягає на сам клуб. У 2015 році був прийнятий Закон України «Про запобігання впливу корупційних правопорушень на результати офіційних спортивних змагань» [14], у якому визначаються принципи діяльності із запобігання корупційним правопорушенням у сфері спорту, суб'єкти здійснення контролю за додержанням законодавства, встановлюється відповідальність за корупційний вплив на результати офіційних спортивних змагань і порушення обов'язків запобігання цьому впливу, визначаються заходи щодо усунення правопорушень, засади, нормативна база та напрями міжнародного співробітництва України 3 питань запобігання корупційним правопорушенням у сфері спорту.

Російський законодавець під час вирішення проблем відповідальності у сфері спорту вибрав інший шлях розвитку, відповідно до якого основні положення, спрямовані на запобігання виникненню правопорушень, втілені в базовому нормативному акті - федеральному законі «Про фізичну культуру та спорт у Російській Федерації». Так, деякі його положення передбачають установлення спеціальної відповідальності для осіб, зайнятих у сфері спорту: ст. ст. 26, 26.1 спрямовані на запобігання використанню допінгу, а ст. 26.2 регулює правовідносини щодо запобігання протиправному впливу на результати офіційних спортивних змагань. Свого часу потужним імпульсом для встановлення та дослідження питань відповідальності у спортивній сфері стала низка подій, що відбулися в Росії. Так, до Федерації самбо Росії був пред’явлений позов про відшкодування шкоди на суму 1 млн. рублів. Причиною стало вбивство, здійснене російським борцем Р. Мірзаєвим [15]. Родичі загиблого вважали, що відповідальність покладається не на самого спортсмена, а на організацію, за допомогою якої він набув певних фізичних навичок. Інша подія, що сталася в Ярославлі, пов’язана з хокейною командою «Локомотив», загиблої в повному складі під час здійснення перельоту в інше місто 7 вересня 2011 року [16]. Чи повинен клуб, крім відшкодування перевізником та страховими компаніями, компенсувати родичам шкоду, пов'язану зі смертю спортсменів? Сьогодні й досі з 2014 року після проведення зимових Олімпійських ігор у Сочі до відповідальності притягаються переважно російські спортсмени, у яких були виявлені позитивні результати відібраних допінгтестів під час проведення змагань.

Сфера корупційних правопорушень у світовому спорті має велику кількість прикладів. Так, в Італії у 2006 році в рамках корупційного скандалу, в якому фігурували провідні футбольні клуби («Ювентус», «Мілан», «Лаціо» тощо), була притягнута до кримінальної відповідальності група футбольних функціонерів, а до клубів застосовані спортивні санкції, що негативно позначилось на їхньому фінансовому стані та репутації [17]. Виник такий прецедент також в Україні, коли у 2010 році футбольні клуби «Карпати» й «Металіст» були звинувачені в наявності домовленостей про результати матчу, що відбувся у рамках чемпіонату України. Органи прокуратури відмовилися порушувати кримінальну справу, посилаючись на відсутність події злочину, що підтверджувало відсутність вини у сторін, однак, провівши власне розслідування, Федерація футболу України дійшла протилежних висновків і була близька до застосування до клубів спортивних санкцій, передбачених регламентом проведення змагань. Спортивний суд у Лозанні (Швейцарія) виніс рішення у цій справі і відсторонив «Металіст» від участі в Лізі Чемпіонів у 2013/14 році. Апеляційна інстанція УЄФА відмовила в задоволенні скарги харків’ян. Цього року в чемпіонаті Вірменії за участь у договірних матчах було покарано 58 футболістів, 3 яких 45 призначено пожиттєву дискваліфікацію, 25 з них мають громадянство України [18]. 
Досліджуючи проблематику відповідальності, Г.К. Матвєєв дійшов обгрунтованого висновку про відповідальність юридичної особи за дії її органів, а також учасників (засновників). Однак якщо ці дії вчинені органом з порушенням компетенції, то юридична особа не може бути визнана відповідальною за дії свого органу [19, с. 219]. Дії зазначених осіб від імені спортивної організації, в іiі інтересах (що полягають у досягненні спортивного результату), але зі спотворенням волі останньої, яка може бути спрямована на досягнення результату лише правомірними засобами, створюють підстави для покладання відповідальності на саму організацію. Порушенням компетенції у цьому разі буде, наприклад, наявність попередніх домовленостей про результати спортивних змагань або їх окремих складових частин. Не викликає сумніву можливість застосування до осіб, винних у порушенні законодавства у сфері фізичної культури і спорту, цивільно-правової, кримінальної, адміністративної чи дисциплінарної відповідальності згідно із законом, що відображено у ст. 54 Закону.

Визначаючи межу відповідальності для осіб, що входять до складу організації, С.М. Братусь зазначав таке: «Працівник під час виконання своїх обов'язків не протистоїть юридичній особі в ролі відмінного від неї суб'єкта права: із сумування службових дій робітників і службовців або дій членів, пов'язаних із здійсненням їх членських обов'язків, і виникає діяльність юридичної особи як цілого та ії відповідальність за шкоду, заподіяну членами та працівниками, що діють в цій ролі, а не в ролі приватних осіб. Відповідальність юридичної особи в цьому разі є відповідальністю не за чужі, а за власні дії» [20, с. 211]. Дії Р. Мірзаєва необхідно розглядати тільки як такі, що здійснюються приватною особою, а не спортивною організацією в рамках іiі діяльності. Необхідно відзначити можливість вчинення протиправних дій, наприклад, спортсменами, тренерами саме в рамках діяльності спортивної організації. Хто буде нести відповідальність у разі смерті спортсмена, причиною якої став удар у боксі, або в результаті зіткнення в хокейному, футбольному матчі? Чи можна покласти матеріальну відповідальність на спортивну організацію в разі порушення спортсменом, тренером правил проведення змагань? У першому випадку «лінією розмежування» має стати вина заподіювача і протиправність його дій, що полягає в порушенні норм кримінального, цивільного, адміністративного права. Діючи в рамках правил, боксер може заподіяти шкоду супернику, однак його дії не матимуть винного й протиправного характеру, що не стане підставою для покладання на нього відповідальності. Відповідно, порушення таких і наявність умислу дадуть змогу застосувати міру відповідальності, яку необхідно буде кваліфікувати вже як відповідальність за дії приватної особи.

Особливо складною для суду щодо вирішення питання відповідальності стала справа, підставою для розгляду якої стали події під час матчу між англійськими футбольними клубами «Манчестер Юнайтед» та «Манчестер Сіті», у якому гравець першого Рой Кин наніс удар гравцю команди суперника, зламавши йому коліно й таким чином завчасно фактично завершивши його професіональну футбольну кар'єру. Це порушення було актом помсти, і умисел заподіювача шкоди було доведено. Сам футболіст відкрито заявляв про свої наміри, говорячи про те, що вже довгий час чекав на зустріч 3 постраждалим футболістом на полі, щоби помститися йому за неспортивну поведінку у матчі трирічної давнини. 3 огляду на це виникає питання про те, як футбольний клуб «Манчестер Юнайтед» міг попередити таку поведінку гравця, яка була відвертим актом його умисної агресії, і чи доцільним є застосування відповідальності до клубу в такому разі, коли гравець діє у манері, непритаманній футболістові. Проте суд установив, що Рой Кин мав жорсткий стиль гри й досить часто порушував правила, клуб знав про це й мав проводити з гравцем відповідну роз'яснювальну та тренувальну роботу, що мала сприяти мінімізації випадків небезпечної гри. 3 огляду на це клуб поніс відповідальність за дії свого футболіста [21].

В теорії держави і права під юридичною відповідальністю прийнято розуміти правовідносини між суб'єктом, який порушив приписи правової норми, з одного боку, і державою в особі його органів або інших організацій, уповноважених визначити стосовно порушника міру відповідальності на підставі правових норм, $з$ іншого боку [22, с. 357]. Цивільно-правова відповідальність справедливо визначається Б.П. Карнаухом як «механізм перерозподілу витрат, заснований на ідеї справедливого відшкодування: витрати того, чиє право порушене, переносяться на того, з чиєї вини сталося порушення» [23, с. 51]. Однак у спеціалізованій літературі дедалі частіше зустрічаються терміни «спортивна відповідальність» [24; 92, с. 133], «спортивно-змагальна відповідальність» [4, с. 29], «спортивні санкції» [25], підстави виникнення, механізми та наслідки застосування яких відмінні від установлених загальним законодавством.

У процесі підготовки спортсмена та проведення змагань виникають ситуації, коли учасники допускають порушення, пов’язані зі специфікою проведення змагань, або з огляду на тактику цього виду спорту, або інші порушення, що впливають на кінцевий результат змагань. Сутність таких порушень може бути різною: порушення правил, регламентів, порядку проведення змагань, антидопінгових вимог тощо. Такі санкції, які містяться в локальних джерелах міжнародних, національних федерацій з видів спорту, дають змогу розділити їх на такі дві категорії: змагально-технічні, які настають за порушення правил проведення спортивних заходів, коли таке порушення безпосередньо пов'язано зі специфікою проведення спортивного змагання, їх зміст полягає в передачі суперникові (суперникам) порушника спортивно-технічних приписів, що містяться в правилах проведення спортивного заходу, деякої змагальнотактичної переваги; спортивно-дисциплінарні (матеріальні), сутність яких полягає в позбавленні (тимчасово або довічно) права порушника на участь у зма- 
ганнях 3 цього виду спорту (дискваліфікація) або обмеженні його майнового положення (грошовий штраф), призначувані за порушення, безпосередньо не пов'язані із сутністю, специфічними принципами організації виду спорту, що, як правило, є такими, що мають більший ступінь суспільної небезпеки [24, с. 72].

Нині відсутність у нормативних актах згадки про спортивну відповідальність та механізм іiі застосування (рішення дисциплінарної комісії при федерації, рішення спортивного арбітражного суду тощо) під час накладення санкції дає деяким дослідникам можливість відносити іiі до різновиду корпоративної відповідальності, що випливає переважно з норм, які містяться в правилах проведення спортивних заходів, прийнятих і розроблених виключно організаціями, координуючими діяльність спортивних організацій [7, с. 132]. Це дає можливість виділити низку характерних для неї критеріїв самостійності. Підтримуючи позицію Д.А. Ліпінського [26, с. 361], зазначимо, що необхідна наявність спеціального нормативно-правового акта, який передбачає юридичну відповідальність. У світі вже існують Спортивні кодекси Франції і Бразилії. В Росії триває активна дискусія про створення аналогічного кодексу, особливості процесуального провадження. Ця відповідальність поширюється на спортивні організації, спортсменів - учасників змагань, а також на інших учасників спортивного заходу (тренери, представники спортсменів, секунданти) за наявності самостійного правопорушення (зі своєю природою об'єкта правопорушення). Дійсно, наприклад, гра рукою у футболі матиме значення правопорушення тільки з огляду на встановлені принципи, правила цієї гри, а вже в іншому виді спорту, наприклад, у баскетболі, це буде допустимо. Також враховується вид установлених несприятливих наслідків вчиненого діяння. Санкції спортивно-змагальної відповідальності також специфічні й матимуть значення тільки з огляду на сутність змагання (штрафний удар або жовта картка у футболі, двохвилинне вилучення в хокеї тощо).

На думку Ж.І. Овсєпян, особливе значення для відособлення в системі юридичної відповідальності самостійного виду має так званий організаційний критерій, де «умовою визнання галузевого блоку норм в ролі галузевого інституту юридичної відповідальності є не тільки розвинена система санкцій норм шуканої галузі права, але й наявність спеціалізованих органів (насамперед, судових), уповноважених спеціально для застосування санкцій норм, співвідносних з галузевою сферою (з цією галуззю права), і особливих правил процедури застосування цих санкцій» [27, с. 34].

Самостійність спортивно-змагальної відповідальності дає змогу виділити низку ії характерних ознак.

1. Вони застосовуються виключно в ході проведення спортивних змагань.

2. Санкції цього виду відповідальності настають за порушення правил проведення спортивних заходів, коли таке порушення безпосередньо пов'язано зі специфікою його проведення.

3. Спрямовані на надання супернику (суперникам) порушника спортивних правил певної переваги в поточному змаганні.

4. До цього виду відповідальності притягуються спортивні організації (наприклад, за невиконання рішень Палати по спорах ФФУ щодо Мілошевича «Карпати» оштрафовано на 25000 гривень, а за невиконання рішення САС Лозанни по Федецькому - на 37500 гривень, в разі невиконання рішень можуть бути застосовані фінансові санкції, такі як заборона на трансферну діяльність, переведення в нижчу лігу або зняття очок [28]), спортсмени-учасники змагань та інші його учасники (тренери, представники, секунданти).

5. Суб'єктом винесення рішення про застосування спортивно-змагальної відповідальності є суддя (рефері, арбітр). Іноді у процес рішення про накладення спортивних санкцій вступають спеціальні органи громадських спортивних організацій (наприклад, рішення арбітражної палати Інстанції 3 фінансового контролю клубів про накладення штрафних санкцій на вісім футбольних клубів у зв'язку 3 наявністю значних заборгованостей перед спортсменами, в тому числі на ФК «Арсенал» Київ, в розмірі 75000 євро від 21 грудня 2012 року № 90 [29]), а також спортивні арбітражні суди.

Висновки 3 дослідження і перспективи подальших розвідок у цьому напрямі. Більш детальне дослідження інших видів юридичної відповідальності та їх застосування в спортивній сфері, наявність спеціального закону, регулюючого відповідальність у галузі спорту, зіграли б важливу роль у розвитку правової бази у сфері спорту.

\section{Список використаних джерел:}

1. Халфина Р.О. Общее учение о правоотношении. Москва : Юридическая литература, 1974. 345 с.

2. Базыкин А.Е. Допинг в спорте. Спортивное право: перспективы развития : материалы II международной научно-практической конференции. Москва : [б. и.], 2009. С. 108-113.

3. Краснова О.Ю. О некоторых проблемах регулирования борьбы с допингом. Спортивное право: перспективы развития : материалы II международной научно-практической конференции. Москва : [б. и.], 2009. С. 124-128.

4. Амиров И.М. Специальная юридическая ответственность в сфере спорта. Спортивное право: перспективы развития : материалы международной научно-практической конференции. Москва : [б. и.], 2011. C. 28-32.

5. Балаганина А.В. К вопросу о спортивных санкциях. Спортивное право: перспективы развития : материалы международной научно-практической конференции. Москва : [б. и.], 2011. С. 32-36. 
6. Овчинникова Н.А. Ответственность организаторов спортивных мероприятий. Спортивное право: перспективы развития : материалы международной научно практической конференции. Москва : [б. и.], 2011. C. 111-115.

7. Прокопец М.А. Спортивная ответственность и спортивные санкции. Спортивное право: перспективы развития : материалы международной научно-практической конференции. Москва : [б. и.], 2007. C. 131-136.

8. Ткалич М.О. Спортивні клуби як учасники цивільних правовідносин : автореф. дис. ... канд. юрид. наук : спец. 12.00.03. «Цивільне право, сімейне право, цивільний процес, міжнародне приватне право». Одеса, 2009. $21 \mathrm{c.}$

9. Журба М.А. Публічне управління у галузі фізичної культури і спорту : дис. ... канд. юрид наук : спец. 12.00.02. Одеса, 2017. 216 с.

10. Облакова О.В. Цивільно-правова відповідальність організаторів спортивних заходів за дії третіх осіб. URL: http://pgp-journal.kiev.ua/archive/2020/6/11.pdf.

11. Тіхонова М.А. Юридична відповідальність у сфері спорту. URL: file://C:/Users/Alex/Desktop/Tixoнова\%20відповідальність\%20спорт.рdf.

12. Про фізичну культуру і спорт : Закон України. Відомості Верховної Ради Украӥни. 1994. № 1. Ст. 1.

13. Про особливості забезпечення громадського порядку та громадської безпеки у зв'язку з підготовкою та проведенням футбольних матчів : Закон України. Офіиійний вісник України. 2011. № 59. Ст. 2346.

14. Про запобігання впливу корупційних правопорушень на результати офіційних спортивних змагань : Закон України. URL: https://zakon.rada.gov.ua/laws/show/743-19\#Text.

15. Семья убитого Агафонова за «воспитание» дагестанца Мирзаева потребует с Федерации самбо 1 млн. евро. URL: http://pan.ru/search/index.php3?act=1\&mn=0\&word=\%F0.+\%EC\%E8\%F0\%E7\%E0\%E5\%E 2\&bid=37124\&id=34322\#34322.

16. ХК «Локомотив» разбился в Ярославле. URL: http://www.eurosport.ru/ice-hockey/khl/2011-2012/ story_sto2940848.shtml.

17. Коррупционный скандал в итальянском футболе. 2006. URL: https:/ru.wikipedia.org/wiki/Koppyпционный_скандал_в_итальянском_футболе_(2006).

18. Кого уличали и как наказали за договорные матчи. URL: https://footballua.tv/news/87506-prestupleniei-nakazanie-kogo-ulichali-i-kak-nakazyvali-za-dogovornye-matchi.

19. Матвеев Г.К. Вина в советском гражданском праве. Киев : Изд-во Киевского государственного университета им. Т.Г. Шевченко, 1955. 306 с.

20. Братусь С.Н. Субъекты гражданского права. Москва : Госюриздат, 1950. 367 с.

21. Keane charged by FA. URL: http://news.bbc.co.uk/sport2/hi/football/teams/m/man_utd/2236929.stm.

22. Цвік М.В., Ткаченко В.Д., Рогачова Л.Л. Загальна теорія держави і права : підручник для студентів юридичних спеціальностей вищих навчальних закладів. Харків : Право, 2002. 432 с.

23. Карнаух Б.П. Вина як умова цивільно-правової відповідальності : монографія. Харків : Право, 2014. 224 c.

24. Амиров И.М. Юридическая ответственность в сфере спорта (вопросы теории и практики) : учебное пособие. Уфа : УЮИ МВД РФ, 2006. 281 с.

25. Маргулис М.А. Нормотворчество корпоративных объединений в области спорта : автореф. дисс. ... канд. юрид. наук : спец. 12.00.01. Москва, 2005. 31 с.

26. Липинский Д.А. Общая теория юридической ответственности : дисс. ... докт. юрид. наук : спец. 12.00.01. Самара, 2004. 487 с.

27. Овсепян Ж.И. Юридическая ответственность и государственное принуждение (общетеоретическое и конституционно-правовое исследование). Ростов-на-Дону : Эверест, 2005. 276 с.

28. «Карпаты» могут опять лишить очков. URL: http://sport.mail.ru/news/football-foreign/20568214.

29. Рішення Інстанції по фінансовому контролю. URL: http://ru.uefa.org/protecting-the-game/clublicensing-and-financialfair-play/news/newsid=1954542.html. 
УДК 347.1:340.132(477)

DOI https://doi.org/10.32836/2521-6473.2020-4.13

\author{
С. В. Завальнюк, кандидат юридичних наук, доцент, \\ доцент кафредри цивільного права \\ Національного університету «Одеська юридична академія»
}

\title{
ПРОБЛЕМАТИКА СПІВВІДНОШЕННЯ ПОНЯТТЯ ПРОГАЛИНИ В ЦИВІЛЬНОМУ ЗАКОНОДАВСТВІ ТА ДЕЯКИХ СХОЖИХ ПРАВОВИХ ПОНЯТЬ І ЯВИЩ
}

Для безпомилкового розуміння поняття прогалини в цивільному законодавстві слід чітко відмежсвувати його від схожсих понять, які можна зустріти в юридичній літературі. Задля відмежсування прогалин в цивільному законодавстві від схожих явищ слід надати їм визначення, дослідити ознаки, причини їх виникнення та вплив на регулювання цивільних правовідносин.

Дослідження питання правової природи правових прогалин у своїх праиях піднімали М.І. Бару, Н.А. Гущина, О.М. Калашник, О.В. Колотова, В.В. Лазарєв, В.М. Марчук, Ф.Р. Уранський, О.М. Ярошенко та багато інших учених. Однак більшість авторів, досліджуючи питання прогалин, майже завжди ототожнювала поняття прогалини у праві з поняттям прогалини у законодавстві, через що в науковій доктрині наявні плутанина та велика кількість неточностей. Також більшість авторів зовсім не розглядала циивільно-правовий аспект поставленого питання, щзо надає статті ще більшої актуальності.

У статті визначено співвідношення поняття прогалини в ичивільному законодавстві та деяких схожих правових понять і явищ («кваліфіковане мовчання законодавияя, «помилка в праві», «удавана потреба у правовому регулюванні», «незрозумілість правових норм», «колізї норм права», «очіночні поняття», «правовий вакуум», «дефект права»). Актуальність окреслених питань обумовлена тим, шо иі поняття часто використовуються в науковій доктрині, але науковиі -юристи часто не надають чіткого визначення цим явищам та не досліджують їх співвідношення з явищем прогалини в циивільному законодавстві Украӥни. Дослідження спрямовано на детальний розгляд наявних підходів до розуміння зазначених понять, визначення й детальне обтрунтування їх співвідношення.

Ключові слова: прогалина, прогалина в законодавстві, прогалина в ичиільному законодавстві, кваліфіковане мовчання законодавия, помилка в праві, удавана потреба у правовому регулюванні, незрозумілість правових норм, колізіі норм права, оціночні поняття, правовий вакуум, дефект права.

S. V. Zavalnyuk. The problems of correlation of the concept of a gap in the civil legislation and some similar law concepts and phenomena

For an unmistakable understanding of the concept of "gaps in civil legislation", it should be clearly separated from similar concepts that can be found in legal literature. In order to distinguish between gaps in civil law from similar phenomena, they should be provided with definitions, investigated signs, the reasons for their occurrence and the impact on the regulation of civil relations.

The study of the legal nature of legal gaps in one way or another was raised in their works: Baru M.I., Gushchina N.A., Kalashnik A.N., Kolotova A.V., Lazarev V.V., Marchuk V.N., Uransky F.R., Yaroshenko O.M. and many others. However, the vast majority of these authors exploring the issue of gaps almost always identify the concept of gaps in law and gaps in legislation, which is why there is confusion and a large number of inaccuracies in the scientific doctrine. Also, most of these authors did not consider the civil law aspect of the question at all, which makes this article even more relevant.

The article defines the correlation of the concept of a gap in the civil legislation and some similar legal concepts and phenomena ("qualified silence of the legislator", "mistake in law", "apparent need for legal regulation", "incomprehensibility of legal norms", "conflict of law", "valuation concepts", "legal vacuum", "defect of law"). The relevance of these issues is due to the fact that these concepts are often used in scientific doctrine, but legal scientists often do not give a clear definition of these phenomena and did not investigate their relationship with the gap in the civil legislation of Ukraine. The research in this article is aimed at a detailed review of existing approaches to understanding these concepts, at the definition and detailed justification of their relationship. Thus, these concepts are often used in the civil literature, so their study and visual distinction is very relevant for the development of jurisprudence. Also, it is important to keep in mind that the application of any means to overcome the gaps in the legislation to these phenomena is unacceptable.

Key words: gap, gap in the legislation, gap in the civil legislation, qualified silence of the legislator, mistake in law, the apparent need for legal regulation, incomprehensibility of legal norms, conflicts of law, valuation concepts, legal vacuum, defect of law.

Постановка проблеми. Для безпомилкового розуміння поняття прогалини цивільного законодавства слід чітко відмежовувати його від схожих понять, які можна зустріти в юридичній літературі.

Аналіз останніх досліджень і публікацій. Дослідження питання правової природи правових прогалин та їх співвідношення зі схожими правовими явищами у своїх працях розглядали М.І. Бару, Н.А. Гущина,

(C) С. В. Завальнюк, 2020 
О.М. Калашник, О.В. Колотова, В.В. Лазарєв, В.М. Марчук, Ф.Р. Уранський, О.М. Ярошенко та багато інших учених. Однак більшість авторів, досліджуючи питання прогалин, майже завжди ототожнювала поняття прогалини у праві з поняттям прогалини у законодавстві, через що в науковій доктрині наявні плутанина та велика кількість неточностей. Також більшість авторів зовсім не розглядала цивільно-правовий аспект поставленого питання, що надає статті ще більшої актуальності.

Мета статті полягає у визначенні поняття прогалини в цивільному законодавстві України та деяких схожих правових понять і явищ, їх розмежуванні та дослідженні їхнього співвідношення.

Виклад основного матеріалу. Задля відмежування прогалин у цивільному законодавстві від інших суміжних явищ слід надати визначення цього поняття. Так, прогалина в цивільному законодавстві являє собою відсутність нормативного врегулювання цивільних відносин, що виражається у відсутності належної норми в законах України, чинних міжнародних договорах України, згода на обов’ язковість яких надана Верховною Радою України, а також постановах Верховної Ради України, указах Президента України, декретах і постановах Кабінету Міністрів України, прийнятих у межах їх повноважень та відповідно до Конституції України і законів України.

Далі варто дослідити та провести розмежування прогалин цивільного законодавства і суміжних понять та явищ. Так, О.В. Колотова виділяє поняття «кваліфіковане мовчання законодавця», яке не так давно почало використовуватись у науковій літературі. Вчена вважає, що поняття «кваліфіковане мовчання законодавця» характеризує такі обставини, за яких законодавчі органи навмисно, цілеспрямовано ухиляються від законодавчого прийняття норми, тобто не врегульовують правовідносини, залишаючи питання відкритим, що виражає відсутність бажання приймати таку норму, при цьому залишає врегулювання правовідносин за межами сфери дії законодавства. Як наслідок, законодавець перекладає правове регулювання відносин на плечі правозастосовувача з розрахунком на те, що буде надана конкретизація його законодавчої волі іншими правовими актами. Також законодавець може прийняти норму, якою буде врегульовано певні правовідносини, але в загальних рисах, чим він забезпечує правозастосовувачу можливість конкретизувати цю норму, тобто надає повноваження на врегулювання правовідносин на власний розсуд [3, с. 56].

Прикладом кваліфікованого мовчання може слугувати прийняття абстрактних (оціночних) понять, у яких відсутнє точне нормативне визначення чи тлумачення (наприклад, «належне виконання договору», «добросовісний набувач», «добросовісність», «розумність», «справедливість»). Часто законодавець свідомо використовує правові абстракції задля великого поширення дії норми на різні життєві обставини й правовідносини та передбачення ймовірних змін цих життєвих обставин та правовідносин. Такі оціночні поняття забезпечують можливість надати свободу тлумачення норми суб'єктом правозастосування з використанням зміни оціночних визначень залежно від наявних обставин. Можна сміливо стверджувати, що застосування оціночних понять у правозастосуванні є проявом динамізму у праві, умовою його пристосованості до змінних ситуацій та обставин [3, с. 56]. За спостереженням, навіть приклади, що наводяться теоретиками, безпосередньо стосуються цивільного права, а це підтверджує, що саме цивільне право передусім потребує вищезгаданого динамізму, варіативності, отже, диспозитивності.

Проте, на нашу думку, є спірним твердження О.В. Колотової про те, що кваліфіковане мовчання законодавця може існувати лише за умови, коли законодавчі органи свідомо не врегульовують конкретні життєві обставини чи суспільні відносини, залишаючи їх врегулювання на розсуд правозастосовця [3, с. 56]. 3 незрозумілих причин науковець виключила з числа суб'єктів правозастосування учасників як договірних, так і позадоговірних цивільних правовідносин, оскільки, відповідно до норм чинного законодавства, учасники цивільних правовідносин керуються нормами права (цивільного законодавства) як під час укладення договорів, так і під час правового регулювання позадоговірних зобов’язань.

Прогалини у цивільному законодавстві слід також відрізняти від таких схожих явищ у правовому регулюванні, як незрозумілість, нечіткість юридичних норм, яким вкрай необхідні роз'яснення або тлумачення, але аж ніяк не нормативна конкретизація законодавчого або іншого компетентного органу. Схожим, але не тотожним, є також поняття помилки у праві, тобто відносин, які перебувають поза межами правового регулювання.

Для цивілістики розмежування перерахованих явищ має неабияке значення, адже галузь цивільного права регулює приватні, в певному сенсі особисті відносини, а визначення неправових відносин такими, що не врегульовані правом через прогалину в праві (законодавстві), створює ризик втручання в позаправову сферу, що певною мірою нівелює диспозитивний характер цивільного права. Крім того, можливим $\epsilon$ порушення положення п. 1 ст. 3 ЦК України про принцип неприпустимості свавільного втручання у сферу особистого життя людини.

Н.А. Гущина разом із прогалинами в законодавстві як правову прогалину досліджує дефекти законодавства. Під поняттям «дефект» (від лат. “Defectus”) дослідниця розуміє ваду, недолік, а недолік є смисловим аналогом прогалини, оскільки в цьому разі йдеться про відсутність чого-небудь [7, с. 192]. Однак науковець наполягає на тому, що не можна ототожнювати поняття прогалини законодавства 3 поняттям дефектів законодавства. Зрештою, правові прогалини наявні тоді, коли певний життєвий випадок перебуває в межах правового регулювання, але його неможливо врегулювати чинними, офіційно визнаними правовими нор- 
мами, оскільки у цьому разі відсутня норма правового регулювання. Також науковець розглядає правову прогалину як об'єктивну неминучість, викликану відставанням правового розвитку від цивільних правовідносин, що швидко еволюціонують [2, с. 9]. Так, уже протягом тривалого часу в різних правових системах утвердився принцип, відповідно до якого суддя не може відмовити в позові через наявну прогалину в законодавстві. Наприклад, ст. 4 Кодексу Наполеона 1804 року свідчила про те, що суддя, який відмовиться судити під приводом мовчання, темряви або недостатності закону, може підлягати переслідуванню за обвинуваченням у відмові в правосудді. Таким чином, справедливим є твердження, що прогалина в законодавстві $\epsilon$ не вадою нормативно-правових актів, а цілком прийнятим і поширеним явищем.

A.M. Майданюк вважає, що прогалину в праві неправильно ототожнювати з поняттям помилки у праві як наслідок хибної оцінки об'єктивних обставин та вияву неправильної волі законодавця, яку було необхідно втілити у правовому нормативному акті (з наведеного видно, що науковець також розглядає право через призму легістської концепції праворозуміння, тому в наступних його твердженнях ми можемо ототожнювати його розуміння поняття прогалини у праві з поняттями прогалин у законодавстві). Отже, помилки у цивільному законодавстві - це зовнішнє вираження дефектної волі суб'єктів нормотворення у сфері правового регулювання особистих немайнових та майнових відносин. До цих випадків належать ті, в яких суб'єкти нормотворення неправильно, помилково вважають певні життєві обставини чи суспільні відносини щодо особистих немайнових і майнових відносин такими, що не потребують правового врегулювання, тому не врегульовують їх нормами цивільного законодавства, тобто залишають прогалини [11, с. 74]. Саме за таких обставин помилка у праві є причиною прогалини у законодавстві. Помилковою є думка правознавців, які стверджують, що коли нормотворчий орган хибно вважає обставини такими, на які не поширюється юридичний вплив, то првозастосовувач не має права здійснювати будь-які дії, що спричиняють юридичні наслідки $[4$, с. 113,114$]$. В такому разі правозастосовувач має право подолати прогалину у цивільному праві (законодавстві) в такий самий спосіб, як і тоді, коли причиною іiї виникнення є не помилка у праві, а, наприклад, динаміка розвитку суспільних відносин.

Явище прогалини у цивільному законодавстві тісно пов'язане з таким явищем, як колізії норм цивільного права. Так, і прогалини, і колізії являють собою види порушень структурної побудови системи права, як наслідок, обидва явища погано впливають на якість правового регулювання цивільних відносин, що призводять до погіршення ефективності впливу цивільного права [11, с. 74].

Часто колізії норм права можуть виникати як результат недотримання правил юридичної техніки в ході здійснення нормотворчої діяльності, а саме не скасовуються старі норми права після прийняття нових; в межах регулювання певної галузі права втручаються норми інших галузей права; суб'єкти нормотворення усувають прогалину у праві, якої не існує [10, с. 68].

Коли наявна суперечливість норм однакової юридичної сили, взаємно поглинаючих одна одну, колізії $\epsilon$ причинами прогалин у цивільному праві. Наприклад, згідно 3 ч. 3 ст. 36 ЦК України, правочини щодо розпорядження майном та інші правочини, що виходять за межі дрібних побутових, вчиняються особою, цивільна дієздатність якої обмежена, за згодою піклувальника [9]. Проте ч. 5 ст. 1032 ЦК України свідчить про те, що під час укладання договору управління майном, якщо власником майна є особа, цивільна дієздатність якої обмежена, установником управління є їі піклувальник [9], тобто піклувальник всупереч вимогам ч. 3 ст. 36 ЦК України не надає згоду на укладення договору (здійснення правочину), а укладає договір (здійснює правочин) від імені особи, дієздатність якої обмежена. На практиці така колізія долається шляхом надання переваги у врегулюванні правовідносин спеціальних норм, у цьому разі ч. 5 ст. 1032 ЦК України.

Враховуючи думку О.М. Ярошенка (який досліджував проблематику прогалин законодавства в контексті трудових відносин), можемо стверджувати, що від прогалин у цивільному праві вкрай важливо відрізняти таке явище, як оціночні поняття [11, с. 75]. У Цивільному кодексі України вживаються такі оціночні поняття: «справедливість», «добросовісність», «розумність», «істотне значення», «поважні причини», «негайно», «систематичне порушення». Варто погодитися з точкою зору М.Й. Бару про те, що застосування норм, які містять оціночні поняття, являє собою особливий прийом, який відрізняється від усунення прогалин у праві і від тлумачення норм права [1, с. 104].

Природа оціночного поняття передбачає навмисне надання органом нормотворення можливості вільно здійснювати розсуд у праві правозастовувачем, тобто робити висновки щодо справи з огляду на всі обставини ситуації. За таких умов прогалини у правовому регулюванні суспільних відносин відсутні, оскільки уповноваження правозастосовувача врегулювати ті чи інші правовідносини за допомогою певного законодавчого акта на власний розсуд фактично виражає волю нормотворця.

У змісті нормативно-правових актів обов’язково будуть присутні оціночні поняття. Однак вони також не будуть свідчити про наявність прогалин у цивільному праві (законодавстві), оскільки часто неможливо надати відповідне юридичне тлумачення певному явищу, яке потребує правової регламентації, правового регулювання [11, с. 76]. Наприклад, у доволі часто вживане в нормативно-правових актах поняття «поважні причини» неможливо вкласти один зміст в усіх випадках. Таким чином, відсутня необхідність нормотворчим органам визначати критерії поважності, надавати загальне для всіх випадків характеристики поважних причин чи називати їх повний перелік [11, с. 76]. 
Враховуючи наведені міркування й твердження О.М. Ярошенка $[11$, с. 76] стосовно оціночних понять, можемо надати визначення оціночного поняття у цивільному законодавстві як особливого способу вираження волі законодавця, яке являє собою встановлене у тексті законодавчого акта положення, що потребує уточнення й конкретизації за певних правових обставин у процесі застосування норм цивільного законодавства відповідним суб'єктом.

Важливо зазначити, що за певних обставин оціночні поняття вкрай необхідні, а в деяких зовсім непотрібні. Слід враховувати можливі негативні наслідки застосування оціночних понять у правовому регулюванні. Так, оціночні поняття уточняються та конкретизуються суб'єктом правозастосування, як наслідок, існує обов'язковість застосування суб'єктивного ставлення під час здійснення розсуду у праві, тому можна стверджувати, що оціночні поняття сприяють проявам псевдотворчого розсуду суб'єктами правозастосування у цивільних правовідносинах. М.Й. Бару наполягає на тому, що негативним наслідкам використання суб'єктивного підходу в наданні правової оцінки життєвим обставинам може запобігти вичерпний або хоча би взірцевий перелік, зазначений у цивільному законодавстві [1, с. 105], тому немає ніяких сумнівів у тому, що суб'єкти законотворчої ініціативи за нагоди мають викласти зміст законодавчого акта таким чином, щоб у ньому норми містили вичерпний перелік обставин та фактів або хоча б мали узагальнену форму, тобто мали вигляд абстрактного визначення. Проте використання оціночних понять у нормах цивільного законодавства $\epsilon$ нормальною практикою, оскільки використання оціночних понять являє собою відсутність конкретизації норм законотворчими органами через неможливість використання іншої правової конструкції з об'єктивних причин. Таким чином, установлення вичерпного переліку обставин і фактів, які підпадають під певне оціночне поняття, не може слугувати гарантією правильного, безпомилкового використання такого поняття $[11$, с. 77]. Використання таких поширених словосполучень, як «аналогічні», «тощо», «та інші», не унеможливлює повною мірою виключення суб'єктивного підходу, тобто ймовірності позаправового розсуду під час урегулювання правовідносин із застосуванням оціночних понять.

Розмежування оціночного поняття та прогалини в цивільному законодавстві полягає в тому, що оціночне поняття наявне в певному вигляді у правовому регулюванні цивільних правовідносин, тоді як під час прогалин взагалі може не бути ніякого правового регулювання, коли воно необхідне. До того ж обидва правові явища можуть мати подібні, іноді аналогічні причини їх походження. Проте розрізнити ці правові явища можна лише після встановлення факту наявності або відсутності прогалини в цивільно-правовому регулюванні в кожній окремій ситуації [11, с. 77].

Окремо необхідно сказати кілька слів про поняття, яке часто зустрічається в науковій літературі, а саме «правовий вакуум», а також про розмежування понять «прогалини в праві», «прогалини в законодавстві» i «правовий вакуум». На думку Ф.Р. Уранського, явище правового вакууму - це відсутність правових норм, які потрібні для врегулювання нововиниклих суспільних відносин, що не були врегульовані раніше, але які потребують такого врегулювання. За підходом науковця прогалина в законодавстві являє собою повну або часткову відсутність норм права у нормативних правових актах, потреба в яких зумовлена динамікою розвитку вже сформованих суспільних відносин і необхідністю їх практичного врегулювання [8, с. 114]. 3 таким баченням питання не можна погодитися повністю, оскільки доволі проблематично розмежувати на практиці суспільні відносини, які тільки-но виникли, і вже сформовані. Тим паче за умови необхідності врегулювання правовідносин на практиці з точки зору юридичної професійної оцінки суспільні правовідносини фактично вже існують незалежно від того, чи наявне в регулювання чинним законодавством [8, с. 114-115].

Як відзначав П.О. Недбайло, прогалина в законодавстві може існувати лише за відсутності законодавчих норм щодо фактів, які за своїм змістом входять у сферу правового регулювання [6, с. 456]. Це твердження чи не найбільше актуальне для цивільного права.

Висновки з дослідження і перспективи подальших розвідок у цьому напрямі. Отже, слід відмежовувати прогалини законодавства від таких схожих правових явищ, як кваліфіковане мовчання законодавця, помилка в праві, удавана потреба у правовому регулюванні, незрозумілість правових норм, колізії норм права, оціночні поняття, правовий вакуум, а також від дефекту права, що є ширшим поняттям, ніж прогалина. Так, зазначені поняття є часто вживаними у цивілістичній літературі, тому їх дослідження та наочне відмежування дуже актуальні для розвитку юриспруденції. Також обов’ язково слід враховувати, що застосування будь-яких способів подолання прогалин законодавства до зазначених явищ неприпустиме.

\section{Список використаних джерел:}

1. Бару М.И. Оценочныепонятия в трудовом законодательстве. Сов гос-80 и право. 1970. № 7. С. $102-107$.

2. Гущина Н.А. Пробелы и дефекты в законодательстве и механизм их устранения. Современное право. 2011. № 6. С. 9-15.

3. Колотова О.В. Відмежування прогалин у праві від суміжних правових явищ. Часопис Київського університету права. 2009. № 3. С. 55-59.

4. Лазарев В.В. Применение советского права. Казань : Изд-во Казан. ун-та, 1972. 200 с.

5. Марчук В.М., Ніколаєва Л.В. Нариси з теорії права : навчальний посібник. Київ : Істина, 2004. 304 с.

6. Недбайло П.Е. Применение советских правовых норм. Москва : Госюриздат, 1960. 511 с. 
7. Современный словарь иностранных слов. Санкт-Петербург, 1994. 752 с.

8. Уранский Ф.Р. К вопросу о понятии и видах пробелов в праве. Вестник Московского университета. Серия 11: Право. 2005. № 5. С. 111-121.

9. Цивільний кодекс України від 16 січня 2003 року. Відомості Верховної Ради України. 2003. № 40-44. Ст. 356 .

10. Ярошенко О.М. До проблеми визначення прогалин у трудовому праві. Проблеми законності. 2005. Вип. 76. С. 65-71.

11. Ярошенко О.М. Розмежування прогалин із суміжними юридичними категоріями у трудовому праві. Проблеми законності. 2009. Вип. 105. С. 71-77. 
УДК 341.9

DOI https://doi.org/10.32836/2521-6473.2020-4.14

\author{
I. В. Паризький, доктор економічних наук, \\ кандидат юридичних наук, професор, \\ профресор кафредри, проректор зі стратегічного розвитку \\ Національної академії управління
}

\title{
СПЕЦИФІКА КОМЕРЦАЛІЗАЦІЇ ПОСЛУГ ЮРИДИЧНОГО КОНСАЛТИНГУ В УКРАЇНІ
}

Актуальність статті полягає в тому, щз в умовах сучасного реформування законодавчої системи України, постійних змін та прийняття нових нормативно-правових актів фізичні та юридичні особи потребують якісного правового захисту своїх прав та інтересів. У зв'язку з изи зростає попит на послуги юридичного консалтингу. Нині в Україні є різні способи надання послуг з юридччного консультування, проте ией ринок ще не достатньо сформований і потребує аналізу специифіки реалізації та можливостей комериіалізації послуг юридичного консалтингу в нинішніх реаліях. У статті визначено зміст та види юридичного консультування, охарактеризовано форми реалізації консалтингових послуг у сфері права. Обтрунтовано потребу комериіалізації послуг юридичного консалтингу в сучасних ринкових умовах господарювання. Визначено специфічні ознаки юридичних послуг, які впливають на проиес та можливості комериіалізації послуг з юридичного консультування. Окреслено проблемні питання комериіалізачїі послуг юридичного консалтингу та надано рекомендачії щчодо їх вирішення. Визначено, щяо юридичний консалтинг як професійна діяльність фахівиів з різних галузей права, метою якої є надання у консультачійній формі кваліфікованої допомоги фізичним і юридичним особам у вирішенні різноманітних правових питань, може бути реалізована у формі внутрішнього (юрисконсульт підприємства, юридичний відділ тощя) та зовнішнього (залучення юридичної особи або фізичної особи-підпиємия, яка займається юридччною практикою, адвоката, юридичної фірми, контори чи адвокатського об’єднання) юридичного консультування. Останній реалізується за рахунок комериіалізащії юридичних послуг.

Ключові слова: юридичний консалтинг, юридична послуга, маркетинг юридичних послуг, консультаційна діяльність, діяльність у сфері права.

\section{V. Paryzkyi. Specificity of commercialization of legal consultancy services in Ukraine}

The relevance of the article is that in the current reform of the legislative system of Ukraine, constant changes and the adoption of new regulations, individuals and legal entities need quality legal protection of their rights and interests. As a result, the demand for legal consulting services is growing. Today in Ukraine there are different ways of providing legal consulting services, but this market is not yet sufficiently formed and requires an analysis of the specifics of implementation and opportunities for commercialization of legal consulting services in the current realities. The essence and types of legal consulting are defined in the article; the forms of implementation of consulting services in the field of law are described. The necessity of commercialization of legal consulting services in the modern market conditions of management is substantiated. The specific features of legal services influencing the process and possibilities of commercialization of legal consulting services are determined. The problematic issues of the commercialization of legal consulting services are identified and recommendations for their solution are given. It is determined that legal consulting as a professional activity of specialists in various fields of law, the purpose of which is to provide qualified assistance to individuals and legal entities in resolving various legal issues can be implemented in the form of internal (legal counsel, legal department, etc.) and external (Involvement of a legal entity or a natural person-entrepreneur engaged in legal practice, a lawyer, law firm, office or law association) legal advice. The latter is implemented through the commercialization of legal services. Legal consulting as a professional activity of specialists in various fields of law, the purpose of which is to provide qualified advice to individuals and legal entities in resolving various legal issues can be implemented in the form of internal (legal adviser, legal department, etc.) and external (involvement of legal a person or a natural person-entrepreneur engaged in legal practice, a lawyer, a law firm, an office or a law firm) legal advice. The latter is realized through the commercialization of legal services.

Key words: legal consulting, legal service, marketing of legal services, consulting activities, activities in the field of law.

Постановка проблеми. В умовах сучасного реформування законодавчої системи України, постійних змін та прийняття нових нормативно-правових актів фізичні та юридичні особи потребують якісного правового захисту своїх прав та інтересів. У зв'язку з цим зростає попит на послуги юридичного консалтингу. Нині в Україні є різні способи надання послуг з юридичного консультування, проте цей ринок ще не достатньо сформований і потребує аналізу специфіки реалізації та можливостей комерціалізації послуг юридичного консалтингу в нинішніх реаліях.

Аналіз останніх досліджень і публікацій. Тематика надання послуг юридичного консультування та його специфічних властивостей висвітлена в працях О.С. Марченко [1; 2], О.О. Хохуляк [8], I.M. Школи

(C) I. В. Паризький, 2020 
[8] та інших науковців. Особливостям маркетингу юридичних послуг присвячені праці В.Д. Мейера [9], Л. С. Шевченко [7], С.С. Яременко [10] та інших учених. Водночас актуальних досліджень, присвячених визначенню специфіки комерціалізації послуг юридичного консалтингу в Україні, недостатньо. в Україні.

Мета статті полягає у характеристиці специфіки комерціалізації послуг юридичного консалтингу

Виклад основного матеріалу. Юридичний консалтинг - це професійна діяльність фахівців 3 різних галузей права, метою якої є надання у консультаційній формі кваліфікованої допомоги фізичним і юридичним особам у вирішенні різноманітних правових питань шляхом правових порад, забезпечення необхідною правовою інформацією і вибору оптимального варіанта вирішення проблеми [1, с. 4]. Головними видами юридичного консалтингу є надання:

- юридичних послуг, тобто функцій, змістом яких є виконання фахівцями з права певних професійних функцій та дій юристів за замовленням клієнтів (представлення інтересів клієнтів у державних та недержавних закладах, складання договорів, претензії, позик тощо);

- юридичних послуг консультативного типу (надання клієнтам професійних порад, рекомендацій, пропозицій стосовно вирішення їх проблем юридичного характеру) [2].

Юридичне консультування як напрям юридичної практичної діяльності та форма правової допомоги здійснюється юрист-консультантами (корпоративними юристами), адвокатами як самозайнятими особами, адвокатськими бюро та адвокатськими об'єднаннями, суб'єктами юридичного консалтингу, тобто юристами, які є фізичними особами-підприємцями, та юридичними фірмами, які мають різні організаційні форми. Вони можуть здійснювати внутрішне юридичне консультування або як корпоративний юрист підприємства, або у складі його спеціалізованого підрозділу (юридичної відділу, служби тощо).

У першому випадку діяльність регулюється положеннями Національного класифікатора України ДК 003:2010 «Класифікатор професій» (КП) [3], отже, визначено такі професії: юрисконсульт, до професійних завдань якого входить забезпечення дотримання законодавства у рамках тієї чи іншої форми правових взаємовідносин суб’єктів господарської діяльності (КП: 2429 Інші професіонали в галузі правознавства: 255001 Юрисконсульт), та спеціаліст-юрисконсульт, який є держслужбовцем (КП: 2419 Професіонали у сфері державної служби, маркетингу, ефективності підприємництва, фінансової діяльності, раціоналізації виробництва та інтелектуальної власності: 2419.376 Спеціаліст-юрисконсульт).

Завдання, функції, права та обов’язки, відповідальність, вимоги до юрист-консультанта визначаються в посадовій інструкції. Типової форми такої інструкції немає, тому кожне підприємство може додати бажані пункти до посадової інструкції юрисконсульта. Загалом завдання та обов'язки юрисконсульта (п. 53 переліку «Професіонали» Довідника № 336 [4]) включають розроблення або участь у розробленні документів правового характеру; методичне керівництво правовою роботою на підприємстві, надання правової допомоги структурним підрозділам; за участю інших підрозділів підготовку матеріалів про розкрадання, розтрати, нестачу, випуск недоброякісної, нестандартної продукції стосовно інших правопорушень для подання їх до слідчих та судових органів; вивчення, аналіз та узагальнення результатів розгляду претензій; оформлення матеріалів про притягнення працівників до дисциплінарної та матеріальної відповідальності; участь у роботі з укладення господарських договорів, розробленні умов колективних договорів; консультування працівників підприємства 3 питань чинного законодавства України, надання допомоги з оформлення документів та актів майново-правового характеру.

3 іншого боку, коли на підприємстві виникає потреба залучення кількох юрист-консультантів, послуги юридичного консалтингу надаються юридичним підрозділом, що може реалізовуватися у таких організаційних формах:

1) юридичний відділ як функціональний підрозділ підприємства;

2) юридичний підрозділ як центр відповідальності, видами якого є центр витрат, який діє на основі кошторису витрат; центр прибутку, якому встановлюються внутрішні ціни на консультаційні послуги, складовою частиною яких є умовно-розрахунковий прибуток; центр інвестицій, спрямований на реалізацію інноваційно-стратегічних консультаційних проєктів;

3) юридична служба - комплекс юридичних підрозділів, створених на підприємстві задля ведення правової роботи;

4) юридичне підприємство як структурна одиниця корпорації, яка здійснює внутрішнє та зовнішнє юридичне консультування.

Вибір організаційної форми внутрішнього юридичного консультування зумовлений багатьма чинниками, серед яких основними є характер, масштаб і структура бізнесу, розмір та етап життєвого циклу підприємства, його фінансові можливості, завдання, які стоять перед керівництвом, рівень кваліфікації персоналу, забезпеченість підприємства інтелектуальними ресурсами, ступінь його інноваційної активності, рівень розвитку ринку юридичних послуг [1]. Проте нині виникають певні прогалини у законодавчому регулюванні роботи юридичної служби приватного та недержавного підприємства. Розробляючи власні положення про юридичну службу, такі підприємства керуються Постановою КМУ «Про затвердження Загального положення про юридичну службу міністерства, іншого 
органу виконавчої влади, державного підприємства, установи та організації» від 26 листопада 2008 р. № 1040 [5], адже для недержавних підприємств досі неприйнято/доповнено жодного нормативно-правового акта 3 цього питання.

Водночас може здійснюватися зовнішнє консультування за умови укладання договору з юридичною особою або фізичною особою-підприємцем, яка займається юридичною практикою, 3 адвокатом, юридичною фірмою, конторою чи іншим адвокатським об'єднанням. У цьому випадку, крім договору, має бути оформлена довіреність на право представляти інтереси підприємства з боку другої сторони, яка дасть змогу залученій за договором особі (чи юридичній особі) здійснювати правову роботу для підприємства.

Хоча незалежно від виду юридичний консалтинг можна розглядати як підприємницьку діяльність фахівців 3 права 3 надання юридичних послуг задля досягнення певного правового результату та отримання прибутку, тобто комерціалізації своїх послуг. Підприємницька складова частина такої діяльності, зокрема, закріплена у Класифікаторі видів економічної діяльності (КВЕД)-2010: Клас 69.10 «Діяльність у сфері права» [6], де передбачено такі можливості ведення діяльності:

- юридичне представництво інтересів однієї сторони, що виступає проти іншої сторони в судах або інших судових органах, як особисто членами колегії адвокатів, так і під їх керівництвом (консультаційні послуги та представництво в цивільних справах; консультаційні послуги та представництво в кримінальних справах; консультаційні послуги та представництво в трудових суперечках);

- загальні консультації та складання юридичних документів, а саме свідоцтв про реєстрацію підприємств, статутів підприємств та інших документів, пов'язаних зі створенням підприємств; патентів і авторських прав; підготовка різних юридичних документів, заповітів, доручень;

- діяльність державних та приватних нотаріусів, судових виконавців, третейських суддів, експертів та арбітрів.

Отже, практикуючі адвокати та юристи (фізичні особи), юридичні фірми, контори, адвокатські об’єднання (юридичні особи) мають повне право на комерціалізацію наданих послуг, а саме отримання прибутку від здійснення своєї професійної діяльності. Проте у цьому процесі необхідно зважати на особливості формування вартості послуг через такі специфічні характеристики юридичних послуг:

- невідчутність, адже юридичні послуги не мають матеріально-речової форми, їх не можна продемонструвати, отже, побачити, поторкати або спробувати перед «купівлею»;

- гетерогенність, адже якість юридичної послуги залежить як від юриста, так і від цілей, інтересів і мотивів клієнта; юридичні послуги через це важко контролювати, втім, можна з великою часткою впевненості визначити фактори їх якості та мотивувати їх позитивні прояви;

- безпосередня невимірюваність, адже, намагаючись знайти показники, які хоча б непрямо характеризували юридичну послугу, клієнт аналізує певні «сигнали», такі як рівень освіти та професійної підготовки юристів, матеріальні докази їх успішності (дипломи, сертифікати, місце в рейтингах), досвід роботи в юридичному бізнесі та конкретній юридичній фірмі, відгуки інших клієнтів;

- невіддільність від використання, адже юридичні послуги надають і споживають в один і той же момент часу і на одному й тому ж робочому місці; в результаті цього особливого значення набуває взаємодія юриста і клієнта, яка визначає не тільки якість послуги, але й тривалість взаємовідносин;

- відсутність у клієнта права власності на юридичну послугу, адже клієнт одержує доступ до юридичних послуг лише на певний час; для нього принципово важливо знати умови, терміни, оплату та зобов’язання сторін по наданню послуги;

- неможливість збереження і накопичення юридичної послуги кліснтом задля продажу або використання у майбутньому [7, с. 69; 8].

Ці особливості юридичних послуг спричиняють складність їх комерціалізації та визначення гідного рівня оплати, адже клієнт не завжди може погодитися із заявленою ціною, оскільки не розуміє всієї складності та процедур роботи, а націлений виключно на отримання позитивного результату, за який готовий сплачувати кошти.

Залежно від виду юридичного консалтингу оплата послуг регулюється різними документами:

1) юрисконсульт, працівник юридичного підрозділу - оплата регулюється на основі трудового договору та в межах, визначених домовленістю між підприємством та консультантом;

2) юридична особа або фізична особа-підприємець, що займається юридичною практикою, адвокат, юридична фірма, контора чи інше адвокатське об'єднання - цивільно-правовим договором; у цьому випадку вартість послуг залежить від обсягу часу роботи; складності та новизни правового питання; терміновості вирішення питання; необхідності відрядження; досягнення під час надання юридичних послуг позитивного результату; репутації юриста тощо; крім того, вона визначається типом системи оплати (табл. 1), тому особливе значення під час комерціалізації юридичних послуг мають взаєморозуміння консультанта і клієнта, їх плідна співпраця та уміння домовлятися щодо вартості послуг та форми їх оплати; хоча, на наше переконання, ключовими під час ціноутворення мають бути прозорість ціноутворення, максимальна ефективність у наданні послуг, прагнення до досягнення кінцевої мети. 
Таблиця 1

Системи оплати послуг юридичного консалтингу

\begin{tabular}{|l|l|}
\hline \multicolumn{1}{|c|}{ Система оплати } & \multicolumn{1}{|c|}{ Принцип установлення вартості юридичної послуги } \\
\hline Фіксована & $\begin{array}{l}\text { Передбачає незмінну вартість юридичних послуг у процесі правової допомоги шляхом } \\
\text { укладення разових договорів щодо надання визначеного обсягу юридичних послуг. } \\
\text { Розмір оплати визначається за домовленістю з клієнтом. }\end{array}$ \\
\hline Фіксована поетапна & $\begin{array}{l}\text { Оплата за надання юридичних послуг, що визначається за домовленістю з клієнтом } \\
\text { та оплачується ним щотижнево, щомісячно, щоквартально або поетапно у ході } \\
\text { виконання послуги тощо. }\end{array}$ \\
\hline Погодинна & $\begin{array}{l}\text { Передбачає оплату юридичних послуг залежно від часу, витраченого юристом за одну } \\
\text { годину роботи. Визначається шляхом укладання довгострокових договорів з надання } \\
\text { юридичних послуг за ступенем звернення клієнта з оплатою за фактично надані по- } \\
\text { слуги з розрахунку вартості однієї години роботи згідно зі встановленими тарифами. }\end{array}$ \\
\hline $\begin{array}{l}\text { Винагорода } \\
\text { за результат }\end{array}$ & $\begin{array}{l}\text { Це загальна винагорода за виконані дії з надання юридичних послуг незалежно } \\
\text { від вибраного тарифу. }\end{array}$ \\
\hline Абонентська & $\begin{array}{l}\text { Передбачає одержання за зниженими цінами необмеженого обсягу юридичних } \\
\text { консультаційних послуг шляхом укладання довгострокових договорів на здійснення } \\
\text { комплексного юридичного обслуговування з фіксованою щомісячною платою. } \\
\text { Сплачується щомісячними платежами. }\end{array}$ \\
\hline Комбінована & $\begin{array}{l}\text { Застосовуєтья у разі складної і довготривалої співпраці між клієнтом та юристом. } \\
\text { Вона включає погодинну ставку за роботу і додатковий гонорар за кінцевий результат. }\end{array}$ \\
\hline
\end{tabular}

Джерело: узагальнено автором

Водночас варто враховувати нематеріальну природу юридичних послуг, яка спричиняє нестабільність попиту та пропозиції на них. Це вимагає від суб'єктів надання юридичних послуг ефективної стратегії пристосування до ринкових умов, покликаної забезпечити попит на власні послуги. У цьому разі варто зважати на те, що ринок юридичних послуг клієнтоорієнтований, тому завдання суб'єкта, що надає юридичні консультаційні послуги, крім якісного виконання своїх професійних обов’язків, полягає в тому, щоб запропонувати таку форму оплати, яка насамперед зручна клієнту.

Нині класичною в Україні вважається погодинна оплата праці, коли юрист реєструє кожну годину витраченого на справи замовника часу, надані послуги та їхню вартість [9]. Проте така система характеризується невизначеністю, адже клієнт не може знати, скільки в результаті коштуватиме юридична послуга. Так, навіть однакові погодинні ставки не гарантують, що рахунок у різних юридичних фірм за подібну роботу буде однаковий, що може залежати від професійних якостей та репутації юриста, які види робіт включено у розрахунок, чи немає бажання завищення вартості або демпінгу цін.

У такому разі, на нашу думку, варто орієнтуватися на світовий досвід оцінки вартості юридичних послуг за «ціннісним підходом», тобто за досягнутими результатами, цінністю наданих послуг, унікальністю розробленого рішення, масштабом та складністю проекту, а не лише за кількістю витрачених годин. При цьому важливо показати, що цінність виконаної роботи відповідає вартості.

Також вважаємо за доцільне сформувати єдині правила встановлення цін на ключові юридичні послуги, адже це значно сприятиме розвитку ринку юридичних послуг, адже виключить із числа конкурентних переваг фактор ціни, а також сприятиме підвищенню якості надання послуг та їх доступності як для юридичних, так і для фізичних осіб.

Крім того, варто звернути увагу на ще одну специфічну особливість комерціалізації послуг юридичного консалтингу, яка полягає у потребі належного підтвердження реальності надання послуг, яка не має матеріального вираження, не має можливості збереження й накопичення юридичної послуги клієнтом задля продажу або використання у майбутньому. У цьому аспекті для підтвердження реальності надання юридичних послуг, крім актів виконаних робіт, потрібні детальні звіти в розрізі розроблених юристом документів, витрачених ним годин, переліку контрагентів клієнта, з яким працював юрист. До того ж необхідне оформлення результатів роботи юриста, наприклад, у формі розроблення договорів, первинних документів, які допоможуть підтвердити надання послуг та правильність визначення іiі вартості. Це зі свого боку сприятиме захисту юристів від скарг клієнтів, підтверджуватиме об’єктивність ціноутворення та якісний підхід до виконання своїх обов'язків.

Висновки 3 дослідження і перспективи подалыших розвідок у цьому напрямі. На підставі проведеного вище аналізу можна резюмувати таке.

1. Юридичний консалтинг як професійна діяльність фахівців з різних галузей права, метою якої $\epsilon$ надання у консультаційній формі кваліфікованої допомоги фізичним і юридичним особам у вирішенні різноманітних правових питань може бути реалізована у формі внутрішнього (юрисконсульт підприємства, 
юридичний відділ тощо) та зовнішнього (залучення юридичної особи або фізичної особи-підприємця, які займаються юридичною практикою, адвоката, юридичної фірми, контори чи адвокатського об'єднання) юридичного консультування. Останній реалізується за рахунок комерціалізації юридичних послуг.

2. У процесі комерціалізації послуг юридичного консалтингу варто враховувати іiї специфічні особливості, такі як невідчутність, гетерогенність, безпосередня невимірюваність, невіддільність від використання, відсутність у клієнта права власності на юридичну послугу, неможливість збереження й накопичення.

3. Попри наявність різних способів установлення вартості юридичних послуг, ціноутворення має бути прозорим, а надання послуг - максимально ефективним, спрямованим на досягнення кінцевої мети. При цьому важливо дотримуватися орієнтації на клієнта та визначати вартість юридичних послуг за «ціннісним підходом», максимально орієнтуватися на досягнутий результат.

4. Задля якісного розвитку ринку юридичних послуг пропонується знизити вплив цінового чинника конкурентоспроможності шляхом формування єдиних засад визначення ціни на ключові (найпоширеніші) юридичні послуги.

5. Для підтвердження факту надання юридичної послуги, крім актів виконаних робіт, потрібно вести детальні звіти в розрізі розроблених юристом документів, витрачених ним годин, переліку контрагентів клієнта, з яким працював юрист, а також мати документально зафіксовані результати роботи юриста, зокрема розроблені договори, первинні документи. Це допоможе підтвердити не тільки реалізацію послуг, але й правильність визначення іiі вартості.

Таким чином, передбачено, що врахування зазначених рекомендацій дасть змогу знизити невизначеність у процесі комерціалізації послуг юридичного консалтингу, сприятиме синергетичному ефекту від максимальної корисності надання юридичних послуг, який проявляється у задоволеності клієнта та зростанні репутації юридичних компаній у разі успішного вирішення юридичної проблеми.

\section{Список використаних джерел:}

1. Марченко О.С. Юридичний консалтинг : конспект лекцій для студентів другого (магістерського) рівня вищої освіти галузі знань 05 «Соціальні та поведінкові науки» спеціальності 051 «Економіка» спеціалізації «Бізнес-консалтинг» фінансово-правового факультету. Харків : Національний юридичний університет ім. Ярослава Мудрого, 2019. 101 с.

2. Марченко О.С. Ринок послуг юридичного консалтингу в умовах інноваційного розвитку економіки : монографія. Харків : Кортес-2001, 2007. 132 с.

3. Національний класифікатор України ДК 003:2010 «Класифікатор професій» (КП) : Наказ Держспоживстандарту України від 28 липня 2010 р. № 327. Дата оновлення: 18 серпня 2020 p. URL: https://zakon.rada.gov.ua/rada/show/va327609-10\#Text.

4. Про затвердження Випуску 1 «Професії працівників, що є загальними для всіх видів економічної діяльності» Довідника кваліфікаційних характеристик професій працівників : Наказ Міністерства праці та соціальної політики України від 29 грудня 2004 р. № 336. URL: https://pravo.uteka.ua/doc/Pro-zatverdzhennyaVipusku-1-Profesii-pracivnikiv-shho-ye-zagalnimi-dlya-vsix-vidiv-ekonomichnoi-diyalnosti-Dovidnikakvalifikacijnix-xarakteristik-profesij-pracivnikiv.

5. Про затвердження Загального положення про юридичну службу міністерства, іншого органу виконавчої влади, державного підприємства, установи та організації : Постанова КМУ від 26 листопада 2008 p. № 1040. Дата оновлення: 15 вересня 2020 p. URL: https://zakon.rada.gov.ua/laws/show/1040-2008$\% \mathrm{D} 0 \% \mathrm{BF} \# \mathrm{Text}$.

6. Клас 69.10 «Діяльність у сфері права». Класифікатор видів економічної діяльності (КВЕД)-2010. URL: http://kved.ukrstat.gov.ua/KVED2010/69/KVED10 69 10.html.

7. Шевченко Л.С. Юридичний маркетинг: від теорії до практики. Економічна теорія та право. 2016. № 2. C. 67-79.

8. Школа I.М., Хохуляк О.О. Ознаки юридичної послуги як об’єкта комерційної діяльності. Вісник Чернівецьккого торговельно-економічного інституту. Економічні науки. 2012. Вип. 2. С. $256-262$.

9. Мейер В.Д. Приватна юридична практика. Київ : Американська асоціація юристів. Правова ініціатива в Центральній та Східній Європі (CEELI), 1994. 40 с.

10. Яременко С.С., Савченко В.О. Специфіка маркетингу юридичних послуг. Академічний огляд. 2017. № 2. C. $65-74$. 
УДК 342.9

DOI https://doi.org/10.32836/2521-6473.2020-4.15

\section{І. О. Волокітенко,}

аспірант Одеського державного університету внутрішніх справ

\section{ШЛЯХИ ВДОСКОНАЛЕННЯ ДІЯЛЬНОСТІ ПРЕВЕНТИВНИХ ПІДРОЗДІЛІВ НАЦІОНАЛЬНОЇ ПОЛЮЦЇ УКРАЇНИ У СФЕРІ ДОТРИМАННЯ ПРАВ ТА СВОБОД ЛЮДИНИ}

У статті досліджено шляхи удосконалення діяльності превентивних підрозділів Національної поліціі України у сфері дотримання прав та свобод людини. Визначено структуру, основні завдання та принципи діяльності підрозділів превентивної діяльності Національної поліції України. Розглянуто функиії підрозділів Департаменту превентивної діяльності Національної поліції України та розроблено пропозиції щзодо внесення організаційно-итатних змін у структуру територіальних органів і підрозділів поліщії. Зазначено, щчо діяльність підрозділів превентивної діяльності Національної поліції України трунтується на принциипах законності, гуманізму, поваги до особи, дотримання прав і свобод громадян, довіри, відкритості та взаємодії з органами державної влади, місцевого самоврядування та громадськості. Серед підрозділів превентивної діяльності Національної поліції України окрему увагу приділено розгляду повноважень підрозділів ювенальної превенції, дільничних офіцерів полічії, поліичейських офіцерів громад, їхніх помічників, поліцейських відділів реагування. Окреслено та визначено напрями удосконалення нормативно-правових актів, щчо регулюють забезпечення підрозділами превентивної діяльності Національної поліції України публічної безпеки і порядку. Запропоновано виділити службове приміщення під поліиейську станцію з урахуванням можливості розміщення у ньому для спільної роботи інспекторів ювенальної превениії, дільничних офіцерів полічії, полічейських офіцерів громад, їхніх помічників, полічейських відділів реагування та забезпечення належними умовами для виконання покладених на них службових завдань. Крім того, сформульовано пропозицію, щзоб навантаження на одного поліцейського територіальних підрозділів превенції та на один наряд реагування патрульної поліиії розраховувалось із кількості населення на визначеній території обслуговування, кількості населених пунктів, протяжності вулично-иляхової мережі, плоші території обслуговування та стану криміногенної ситуації.

Ключові слова: адміністративно-правовий статус, функиї поліиії, органи поліиії, Департамент превентивної діяльності Національної полічії України, превенція, профілактична діяльність.

I. O. Volokitenko. Ways to improve the activities of preventive units of the National Police of Ukraine in the field of human rights and freedoms

The article explores ways to improve the activities of preventive units of the National Police of Ukraine in the field of human rights and freedoms. The structure, main tasks and principles of activity of subdivisions of preventive activity of the National Police of Ukraine are determined. The functions of the divisions of the Department of Preventive Activities of the National Police of Ukraine are considered and proposals for making organizational and staffing changes in the structure of territorial bodies and police divisions are developed. It is noted that the activities of preventive units of the National Police of Ukraine are based on the principles of legality, humanism, respect for the individual, respect for the rights and freedoms of citizens, trust, openness and interaction with public authorities, local governments and the public. Among the preventive units of the National Police of Ukraine, special attention is paid to the consideration of the powers of juvenile prevention units, district police officers, community police officers, their assistants, and police response units. The directions of improvement of normative-legal acts regulating provision of divisions of preventive activity of the National Police of Ukraine of public safety and order are outlined and defined. It is proposed to allocate office space for the police station, taking into account the possibility of hosting juvenile prevention inspectors, district police officers, community police officers, their assistants, police response units and providing appropriate conditions for their duties. In addition, a proposal was made to calculate the workload per one police officer of the territorial prevention units and one patrol police response team from the population in a given service area, the number of settlements, the length of the road network, the area of the service area and the crime situation.

Key words: administrative and legal status, police functions, Police authorities, Department of Preventive National Police of Ukraine, prevention, prevention activities.

Постановка проблеми. Наближення стандартів професійної підготовки та службової діяльності підрозділів поліції превентивної діяльності Національної поліції України до загальновизнаних у міжнародних відносинах норм і стандартів, а також до відповідних стандартів європейських та інших країн є одним 3 основних напрямів реформування системи правоохоронних органів України. Відповідно до нового адміністративно-територіального устрою згідно з Постановою Верховної Ради України «Про утворення та ліквідацію районів» від 17 липня 2020 року № 807-IX [1], сьогодні запроваджуються нові організаційно-штатні зміни у структурі територіальних органів, підрозділів поліції, що обумовлює розроблення та визначення

(C) І. О. Волокітенко, 2020 
таких категорій: цілі, завдання діяльності, структурно-організаційні та компетенційні елементи, спрямовані на забезпечення прав і свобод людини, інтересів суспільства й держави, протидію злочинності, підтримання публічної безпеки та порядку, а також надання в межах, визначених законом, послуг особам.

Аналіз останніх досліджень і публікацій. Загальнотеоретичним аспектам організаційно-правових основ діяльності поліції України присвячено праці вчених-адміністративістів, таких як О.М. Бандурка, О.І. Безпалова, С.М. Гусаров, О.В. Джафарова, О.С. Доценко, О.М. Заєць, Д.П. Калаянов, В.В. Конопльов, О.В. Кузьменко, Є.В. Курінний, О.В. Негодченко, А.В. Панчишин, К.М. Руда, Ю.В. Сіроштан, С.О. Шатрава. Стосовно дослідження цілей, завдань, форм та методів діяльності підрозділів превентивної служби Національної поліції України на теренах сучасного українського адміністративного законодавства та в контексті реформування системи МВС України існують лише поодинокі наукові розробки.

Мета статті полягає в узагальненні пропозицій щодо удосконалення превентивної діяльності підрозділів Національної поліції України.

Виклад основного матеріалу. Відповідно до Положення про Національну поліцію України, затвердженого Постановою Кабінету Міністрів України від 28 жовтня 2015 року № 877 [4], підрозділи превентивної діяльності входять до складу Департаменту превентивної діяльності Національної поліції України. Управління превентивної діяльності є структурним підрозділом територіальних Головних Управлінь (Управлінь) Національної поліції в областях з питань охорони публічного порядку, забезпечення публічної безпеки, охорони прав і свобод людини, а також інтересів суспільства й держави та протидії злочинності.

До структури Департаменту поліції превентивної діяльності центрального апарату Національної поліції України віднесено управління груп реагування патрульної поліції; управління порядку та публічної безпеки; управління офіцерів поліції; управління ювенальної превенції; управління масових і охоронних заходів; управління щодо контролю за обігом зброї у сфері дозвільної системи; управління аналізу та планування спеціальних заходів; управління забезпечення безпеки дорожнього руху; відділ впровадження системи автоматичної фіксації порушень правил дорожнього руху та аналізу стану доріг.

Самостійним структурним підрозділом Головних (територіальних) управлінь Національної поліції України в областях, який у межах своєї компетенції реалізує державну політику у сферах забезпечення публічної безпеки й порядку, безпеки дорожнього руху, організації роботи дозвільної системи, превентивної та профілактичної діяльності, запобігання домашньому насильству та його припинення, є Управління поліції превентивної діяльності.

Діяльність управління грунтується на принципах законності, гуманізму, поваги до особи, дотримання прав і свобод громадян, довіри, відкритості та взаємодії з органами державної влади, місцевого самоврядування та громадськості [12].

Основними функціями Управління поліції превентивної діяльності є захист прав, свобод, та законних інтересів громадян, запобігання правопорушенням та їх припинення; забезпечення охорони громадського порядку та громадської безпеки на вулицях та в інших громадських місцях (зокрема, в місцях проведення масових заходів), профілактика правопорушень у взаємодії з іншими службами і підрозділами Національної поліції, органами державної влади та місцевого самоврядування, а також об'єднаннями громадян; організація проведення загальної та профілактичної роботи серед населення, взаємодії з громадськими формуваннями щодо охорони громадського порядку, участі разом з іншими службами та підрозділами Національної поліції у виявленні, попередженні та припиненні правопорушень; здійснення ліцензування певних видів господарської діяльності, забезпечення дозвільної системи та державного охоронного нагляду; забезпечення охорони затриманих і взятих під варту осіб під час їх тримання у спеціальних установах поліції та конвоювання до органів суду, прокуратури та досудового слідства; організація і контроль за станом виконання підпорядкованими підрозділами превентивної діяльності нормативно-правових актів; реалізація в межах своєї компетенції державної політики щодо забезпечення безпеки дорожнього руху; організація контролю за додержанням законів, інших нормативних актів з питань безпеки дорожнього руху та охорони навколишнього середовища від шкідливого впливу автомототранспортних засобів (далі - транспортних засобів); удосконалення регулювання дорожнього руху задля забезпечення його безпеки та підвищення ефективності використання транспортних засобів; виявлення та припинення фактів порушення безпеки дорожнього руху, а також виявлення причин та умов, що сприяють їх вчиненню [13].

Задля дотримання прав і свобод людини, додержання гарантій із захисту прав та інтересів осіб, які постраждали від домашнього насильства, насильства за ознакою статі, а також забезпечення належного реагування на випадки такого насильства, надання допомоги постраждалим особам, створення умов для реалізації кожною дитиною права на зростання у безпечному сімейному оточенні з огляду на зростання викликів, пов’язаних із вчиненням домашнього насильства внаслідок зменшення латентності таких правопорушень, великий суспільний резонанс, а також для ефективної реалізації Указу Президента України «Про невідкладні заходи із запобігання та протидії домашньому насильству, насильству за ознакою статі, захисту прав осіб, які постраждали від такого насильства» від 21 вересня 2020 року № 398/2020 пропонуємо у кущових підрозділах поліції, які створені на базі обласних центрів та містах Сєвєродонецьк і Маріуполь у відділах превенції, утворити сектори протидії домашньому насильству, до складу яких, зокрема, будуть входити 
поліцейські, задіяні до роботи у мобільних групах з реагування на факти вчинення таких правопорушень, які нині успішно функціонують у межах реалізації відповідного проєкту.

Пропонуємо такий штатний розпис цього сектору, що налічуватиме від 10 посад на одну мобільну групу (залежно від кількісного навантаження викликів про факти вчинення домашнього насильства) з такого розрахунку: 1 - начальник сектору, 1 - старший інспектор та інспектори.

Окремо слід зазначити, що, відповідно до Наказу МВС «Про затвердження Інструкції з організації роботи підрозділів ювенальної превенції Національної поліції України» від 19 грудня 2017 року № 1044 , основними завданнями є такі:

- профілактична діяльність, спрямована на запобігання вчиненню дітьми кримінальних і адміністративних правопорушень, виявлення причин та умов, які цьому сприяють, вжиття в межах своєї компетенції заходів для їх усунення;

- ведення профілактичного обліку дітей, схильних до вчинення правопорушень, а також проведення з ними заходів індивідуальної профілактики;

- участь в установленні місця знаходження дитини в разі ії безвісного зникнення чи отриманні даних для цього в межах кримінального провадження, відкритого за фактом іiі безвісного зникнення;

- вжиття заходів щодо запобігання та протидії домашньому насильству, вчиненому дітьми та стосовно них, а також жорстокому поводженню $з$ дітьми;

- вжиття заходів щодо запобігання дитячій бездоглядності, зокрема здійснення поліцейського піклування щодо неповнолітніх осіб;

- провадження діяльності, пов’язаної із захистом права дитини на здобуття загальної середньої освіти.

3 огляду на те, що не у кожному територіальному (відокремленому) підрозділі поліції згідно зі штатного розпису є посада інспектора ювенальної превенції або така посада лише одна, пропонуємо у відділі превенції районних (кущових) управлінь відповідного нового адміністративно-територіального устрою районів створити сектори ювенальної превенції за рахунок штатних посад поліцейських ювенальної превенції відділів (відділень) поліції, які обслуговують територію цих районів.

При цьому частково повноваження щодо лінії ювенальної превенції на рівні цих підрозділів поліції виконуватимуть дільничні офіцери поліції, поліцейські офіцери громади (відповідні зміни внесені до Наказу МВС «Про затвердження Інструкції з організації діяльності дільничних офіцерів поліції» від 28 липня 2017 року № 650) та, як виняток, інспектори ГРПП. Зокрема, йдеться про такі функції:

- вжиття заходів щодо встановлення особи дитини, місця іiї проживання, відомостей про батьків або осіб, які їх замінюють, інших родичів, місця їх проживання (перебування) у разі надходження повідомлення про дитину, яка залишилась без батьківського піклування (щодо випадків, які не потребують відкриття кримінального провадження та заведення ОРС «Розшук»).

- вжиття у разі безпосередньої загрози життю або здоров’ю дитини заходів до відібрання дитини у батьків та тимчасового влаштування іiї відповідно до чинного законодавства;

- здійснення роботи із запобігання вчиненню правопорушень.

Такий розподіл повноважень дасть змогу «розгрузити» поліцейських ювенальної превенції щодо некритичних випадків та вживати заходів щодо якісної профілактичної роботи, імплементації кращого міжнародного досвіду поліції щодо роботи з дітьми, розшуку безвісти зниклих дітей, які можуть стати жертвами злочинів, виявляти правопорушення стосовно дітей, а також документувати їх. Сектор ювенальної превенції надає методичну допомогу та координує виконання завдань між секторами дільничних офіцерів поліції, поліцейських офіцерів громади та груп реагування патрульної поліції.

Відділи реагування патрульної поліції включають такі посади: начальник відділу, заступник начальника, старший інспектор (3). У складі відділу з урахуванням особливостей території обслуговування та за необхідності пропонується утворити сектор поліції на воді.

Відділ реагування патрульної поліції організовує роботу груп реагування патрульної поліції (далі ГРПП) в межах території обслуговування району. Він надає їм практичну та методичну допомогу щодо підвищення ефективності роботи, взаємодіє під час вирішення цих питань з ВРПП інших районних управлінь (відділів) ГУНП в області, іншими структурними підрозділами Національної поліції, органами місцевого самоврядування, підприємствами, установами, організаціями всіх форм власності, громадянами. Відділу слід підпорядкувати ГРПП, тобто наряди у складі не менше двох поліцейських, які нестимуть службу в дві зміни по 12 годин на добу на території обслуговування всього районного управління (відділу).

Також у територіальних відділеннях поліції (далі - ТВП) районного управління (відділу) поліції, які розташовані у межах понад 25 км від районного управління і в яких передбачено несення служби 2 та більше ГРПП в одну зміну, створюється сектор реагування патрульної поліції (далі - СРПП) у складі начальника сектору, старшого інспектора та інспекторів (поліцейських) ГРПП. СРПП базується на території ТВП, де зберігаються їх табельна вогнепальна зброя, спецзасоби, службові транспортні засоби, пально-мастильні матеріали та службова документація. Водночас СРПП виводиться з підпорядкування ТВП та безпосередньо підпорядковується ВРПП районного управління (відділу). Контроль за їх службовою діяльністю безпосередньо здійснюють начальник СРПП та уповноважені інспектори сектору адміністративної практики. 
За аналогічних умов несення служби передбачено лише 1 ГРПП в одну змін, тому безпосереднє підпорядкування здійснюється начальникові СРПП найближчого за територіальністю в межах району обслуговування.

У ТВП районного управління (відділу) поліції, які розташовані у межах 50 км від районного управління та у яких передбачено несення служби 1 ГРПП в одну зміну, сектор реагування патрульної поліції не створюється. ГРПП базується на території ТВП, де зберігаються їх табельна вогнепальна зброя, спецзасоби, службові транспортні (транспортний) засоби та службова документація. Водночас ГРПП виводиться з підпорядкування ТВП та безпосередньо підпорядковується ВРПП районного управління (відділу).

Обслуговування території відділення поліції здійснюватимуть поліцейські відділу реагування патрульної поліції та/або сектору реагування, що є найближчим за територіальністю.

Навантаження на одного поліцейського територіальних підрозділів превенції та на один наряд реагування патрульної поліції слід розраховувати 3 кількості населення на визначеній території обслуговування, кількості населених пунктів, протяжності вулично-шляхової мережі, площі території обслуговування та стану криміногенної ситуації.

Пропонується відійти від методології розрахунків 1 наряд ГРПП на 25 тис. населення та, наприклад, запровадити розрахунок одного наряду на площу в квадратних кілометрах.

За необхідності та з урахуванням особливості території обслуговування слід утворити сектор поліції на воді, у якому необхідно передбачити такі основні напрями діяльності:

- вжиття заходів 3 виявлення та припинення кримінальних та адміністративних правопорушень в акваторіях рік, озер, водосховищ, внутрішніх водоймах, а також прибережній морській зоні на території обслуговування;

- виявлення та припинення фактів незаконного видобутку водних живих ресурсів в акваторіях рік, озер, водосховищ, внутрішніх водоймах, а також прибережній морській зоні на території обслуговування;

- виявлення фактів порушення порядку промислового рибальства та незаконного зайняття рибним промислом на території обслуговування;

- в межах своєї компетенції вжиття заходів із забезпечення публічної безпеки й порядку на території морських та річкових портів, інших об’єктів інфраструктури морського та річкового транспорту;

- в межах своєї компетенції здійснення контролю за дотриманням власниками (володільцями) суден законодавства про судноплавство;

- здійснення взаємодії з іншими районними управліннями (відділами) ГУНП в області, іншими структурними підрозділами Національної поліції, органами державної влади, місцевого самоврядування, підприємствами, установами, організаціями з питань забезпечення безпеки судноплавства, охорони, використання та відтворення водних біоресурсів;

- в межах своєї компетенції організація та здійснення заходів щодо рятування людей, забезпечення їх безпеки у разі стихійного лиха, аварій, катастроф та ліквідації їх наслідків.

Сектор адміністративної практики включає таких членів: начальник, заступник начальника, старший інспектор (3), інспектор (4), поліцейський (4). Пропонуємо розширити функціональні напрями роботи сектору адміністративної практики таким чином:

- забезпечення взаємодії з черговими службами територіальних управлінь (відділів) поліції;

- забезпечення методичного супроводження діяльності нарядів ГРПП, дільничних офіцерів поліції, поліцейських офіцерів громад (далі - наряди);

- здійснення цілодобового моніторингу та контролю за службовою діяльністю нарядів, а також виконання ними службових завдань, зокрема створених самостійно;

- надсилання за погодженням з оперативним черговим районного управління нарядам електронних службових завдань та контроль за їх виконанням;

- здійснення контролю за станом адміністративної діяльності як районного управління (відділу) поліції, так і його територіальних підрозділів;

- в межах компетенції здійснення координації з районними судами по справах про адміністративні правопорушення 3 огляду на те, що система судоустрою на практиці не завжди може співпадати 3 новоутвореним адміністративно-територіальним устроєм, це дає підстави вважати, що місцеві суди продовжують здійснювати розгляд справ у межах раніше визначених районів.

Під час розгляду питання щодо виділення службового приміщення під поліцейську станцію враховується можливість розміщення в ньому для спільної роботи інспекторів ювенальної превенції, дільничних офіцерів поліції, поліцейських офіцерів громад, їхніх помічників, поліцейських відділів реагування та забезпечення належними умовами для виконання покладених на них службових завдань.

Службова діяльність зазначених структурних підрозділів організовується відповідно до вимог чинного законодавства України та відомчих нормативно-правових актів, які регламентують діяльність поліцейських, закріпивши їх за поліцейськими дільницями та територіями обслуговування підрозділів реагування в межах ОТГ.

Висновки 3 дослідження і перспективи подальших розвідок у цьому напрямі. Зростання авторитету Національної поліції України слід супроводжувати помітним для населення підсиленням технічної 
забезпеченості поліції, підвищенням ефективності роботи, вжиттям інших організаційних заходів, удосконаленням правового регулювання діяльності задля забезпечення прав і свобод людини, інтересів суспільства й держави, протидії злочинності, підтримання публічної безпеки та порядку, а також надання в межах, визначених законом, послуг особам, що обумовлюють компетенцію та місце підрозділів превентивної діяльності в структурі Національної поліції України.

\section{Список використаних джерел:}

1. Про утворення та ліквідацію районів : Постанова Верховної Ради України від 17 липня 2020 року № 807-IX. URL: https://zakon.rada.gov.ua/laws/show/807-20.

2. Про Національну поліцію : Закон України від 2 липня 2015 року № 580-VIII. URL: http://zakon0.rada.gov.ua/laws/show/580-19.

3. Про затвердження інструкції з оформлення матеріалів про адміністративні правопорушення : Наказ MBC України від 6 листопада 2015 року № 1376. URL: http://zakon3.rada.gov.ua/laws/show/z1496-15.

4. Про затвердження Положення про Національну поліцію : Постанова Кабінету Міністрів України від 28 жовтня 2015 року № 877. URL: http://zakon3.rada.gov.ua/laws/show/877-2015.

5. Про Міністерство внутрішніх справ України : Постанова Кабінету Міністрів України від 28 жовтня 2015 року № 878. URL: http://www.kmu.gov.ua/control/uk/cardnpd?docid=248608057.

6. Про затвердження положення про дозвільну систему : Постанова Кабінету Міністрів України від 12 жовтня 1992 року № 576. URL: http://zakon5.rada.gov.ua/laws/show/576-92-\%D0\%BF.

7. Про затвердження положення про патрульну службу : Наказ МВС України від 2 липня 2015 року № 796. URL: http://zakon2.rada.gov.ua/laws/show/z0777.

8. Про реалізацію повноважень Національної поліції України з питань видачі та анулювання дозволів : Наказ МВС України від 29 грудня 2015 року № 1644. URL: http://zbroya.info.

9. Про затвердження положення про Департамент превентивної діяльності Національної поліції України : Наказ МВС України від 27 листопада 2015 року № 123. URL: http://zakon4.rada.gov.ua/laws/show/ z0213-94.

10. Волокітенко О.І. Основні принципи діяльності підрозділів превентивної служби Національної поліції України. Стан та перспективи розвитку адміністративного права України : матеріали III Міжнародної науково-практичної конференції, м. Одеса, 12 жовтня 2016 року. Одеса : ОДУВС, 2016. 224 с.

11. Волокітенко І.О. Питання взаємодії між працівниками превентивної діяльності та підрозділами Національної поліції України. Науковий вісник Ужгородського національного університету. Серія: Право. 2017. № 43. T. 4. C. 211-215.

12. Довідник працівника поліції превентивної діяльності : навчальний посібник / кол. авт. ; кер. авт. кол. А.С. Фоменко. Дніпро : ДДУВС, 2018. 180 с.

13. Функції та структура Національної поліції (Інфографіка). URL: http://portal.lviv.ua/news/2015/10/29/ funktsiyi-ta-struktura-natsionalnoyi-politsiyi-infografika. 
УДК 348.98

DOI https://doi.org/10.32836/2521-6473.2020-4.16

О. В. Карнаухов, кандидат юридичних наук, доцент, доцент кафедри правоохоронної діяльності

та кримінально-правових дисциплін

Університету митної справи та фрінансів

\section{АНТОЛОГІЯ КРИМІНАЛІСТИЧНОГО ЗАБЕЗПЕЧЕННЯ (ЗМІСТ СИСТЕМИ, КАТЕГОРІЯ ТА ЇÏ КРИТЕРІї)}

Вирішення актуальної проблеми діяльності органів кримінальної юрисдикиії з виявлення, розслідування та судового розгляду кримінальних деліктів потребує створення теоретичної концепції визначення змісту категорї «криміналістичне забезпечення» та наукового формулювання визначення. У попередніх статтях досліджено історичні передумови виникнення та теоретичні проблеми розвитку теорії криміналістичного забезпечення. Надано та проаналізовано у ретроспективі позищї сучасних учених-криміналістів. Представлено основоположні конщепцї теорії криміналістичного забезпечення. Показано генезис розвитку теорії криміналістичного забезпечення, який вбачається у значному розширенні уяви про ї̈ практичну значущість через поширення не просто на кримінальні правопорушення, але й на кримінальні процесуальні процедури. Дослідження сучасного стану теорії криміналістичного забезпечення та ї̈ перспективного розвитку здійснювалось на основі методологї̈ системної діяльності, щзо дало можливість значно розиирити ї̈ науково-практичний зміст. Саме побудова пізнавальних процесів у сфері криміналістичного забезпечення може й має відбуватися у контексті наукового вдосконалення як самої категорії «криміналістичне забезпечення», так і їі змісту. Аналіз наукових уявлень щзодо змісту иієї категорії показує, щцо без належних критерїв криміналістичного забезпечення, які б суворо визначали межі системної діяльності, не може бути досягнуто мети кримінального судочинства, а саме прийняття законного та справедливого остаточного рімення у кримінальному провадженні. При иьому криміналістичне забезпечення не є самочіллю під час відновлення сочіальної справедливості, воно є лише засобом для досягнення мети кримінального судочинства. Сформульовано загальні категоріальні уявлення про поняття та зміст системи криміналістичного забезпечення діяльності органів кримінальної юрисдикиії.

Ключові слова: криміналістика, системний підхід, підсистеми, криміналістичне забезпечення, нормативно-правове забезпечення, організаційно-кадрове забезпечення, технічне забезпечення, інформачійно-методичне забезпечення.

\section{O. V. Karnauhov. Anthology of criminalistics providing (system variable, category and its standard)}

Solving the urgent problem of the activity of the criminal jurisdiction in the detection, investigation and trial of criminal offenses requires the creation of a theoretical concept of determining the content of the category "criminalistics providing" and formulating a definition. Previous articles have explored the historical background and theoretical problems of the development of criminalistics providing theory. The position of modern criminalistics scientists is presented and analyzed in retrospect. The basic concepts of the theory of criminalistics providing are presented. The genesis of the development of the theory of criminalistics providing, which is seen in the significant expansion of the idea of its practical importance due to the spread not only of criminal offenses but also of criminal procedural procedures, is shown. Investigation of the current state criminalistics providing theory and its prospective development was carried out on the basis of the methodology of systematic activity, which made it possible to significantly expand its scientific and practical content. It is the construction of cognitive processes in the field criminalistics providing that can and should take place in the context of scientific improvement of both the category of "criminalistics providing" and its content. An analysis of the scientific perceptions of the content of this scientific category show that without proper criminalistics providing criteria that would strictly define the boundaries of systemic activity, the purpose of criminal justice cannot be achieved, namely, making a legitimate and just final decision in criminal proceedings. Moreover, criminalistics providing is not an end in itself in the restoration of social justice; it is a means of achieving the purpose of criminal justice. The general categorical ideas about the concept, content of the system of criminalistics providing of activity of bodies of criminal jurisdiction are formulated.

Key words: criminalistics science, systematic approach, subsystems, criminalistics providing, regulatory and legal providing, organizational and personnel providing, technical providing, information and methodological providing.

Постановка проблеми. Актуальною проблемою побудови теоретико-практичної конструкції теорії криміналістичного забезпечення діяльності органів кримінальної юрисдикції є визначення ії змісту та критеріїв поняття.

Аналіз останніх досліджень і публікацій. Побудова пізнавальних процесів у сфері криміналістичного забезпечення відбувається в контексті наукового вдосконалення як самої категорії «криміналістичне забезпечення», так і її змісту. Однак криміналістичне забезпечення не є самоціллю у кримінальній юстиції, воно може бути лише засобом для відновлення соціальної справедливості.

(C) О. В. Карнаухов, 2020 
Формуванню теорії криміналістичного забезпечення сприяли фундаментальні розробки основ кримінального судочинства такими відомими вченими, як С.А. Альберт, Ю.М. Грошевий, М.М. Міхеєнко, М.С. Строгович, В.М. Тертишнік, П.І. Репешко, Л.М. Лобойко, М.А. Чєльцов.

Подальше розроблення основ теорії криміналістичного забезпечення здійснювали Т.В. Авер’янова, В.П. Бахін, О.Н. Колісниченко, І.О. Ієрусалімов, Є.Д. Лук’янчиков, Г.Ф. Матусовський, М.П. Яблоков та інші науковці.

Методологічні, науково-практичні та організаційні проблеми виявлення й досудового розслідування кримінальних правопорушень опрацьовували К.В. Антонов, В.В. Варава, Н.С. Карпов, В.В. Лисенко, К.О. Чаплинський, В.Ю. Шепітько та інші вчен.

Мета статті полягає у дослідженні змісту системи, формулюванні категорії та визначенні наукових критеріїв, яким має відповідати система криміналістичного забезпечення та їі складові частини.

Виклад основного матеріалу. Специфіка досліджуваної нами проблеми вимагає науково обгрунтованого підходу до іiї вирішення, тому, пізнаючи та формуючи зміст системи криміналістичного забезпечення, ми маємо сприймати ії як «смислоутворюючу» матрицю та виходимо з того що, по перше, вона є складною системою, по друге, ця система є підсистемою більшої системи.

Центральним у такому підході є поняття системи, при цьому треба зауважити, що суттєві властивості системи визначаються не стільки властивостями сукупності елементів, скільки властивостями ії структури, системоутворюючими зв'язками об'єкта [1].

Будь-яка система - це не тільки розподіл іï складових частин на групи (тобто не тільки класифікація), це не просто сукупність складових частин. Система - це така сукупність складових частин, їх груп, які мають певні взаємозв’язки між собою та із середовищем [2, с. 19-24]. В енциклопедичному словнику поняття «система» визначається, як сукупність пов'язаних між собою елементів (предметів, явищ, поглядів, знань тощо), які становлять певне цілісне утворення, єдність [3]. Нині існує багато визначень цієї категорії. Так, Л. Берталанфі визначив систему як «комплекс компонентів, що взаємодіють» чи «як сукупність елементів, які перебувають у певних відносинах один з одним та середовищем» [4].

Отже, ми розглядаємо систему як упорядковану сукупність об'єктів, об'єднаних будь-якими системними зв'язками, що призначені для досягнення чітко визначеної мети найкращим чином.

Визначаючи зміст вищеозначеної системи як системи способів, засобів та методів, що дають можливість компетентним посадовим особам органів кримінальної юрисдикції виявляти обставини, що підлягають доказуванню, ми не можемо зводити його лише до констатації факту наявності цих ознак.

Формуючи зміст системи криміналістичного забезпечення діяльності органів кримінальної юрисдикції, ми вбачаємо такі чотири комплекси проблем:

- проблема раціональної організації підсистем і розподілу ресурсів способами, які достатні для досягнення цілей системи;

- проблема визначення мети й підтримки процесу їі досягнення (проблема цілеорієнтації);

- проблема несуперечливості та достатньої інтеграції підсистем;

- проблема підтримки мотивацій суб'єктів системи криміналістичного забезпечення під час виконання ними своїх функцій, шляхи розв'язання яких перебувають у площині відповідності засобів та способів наявній меті.

Відповідно до загальновизнаних наукових поглядів, система - це цілісність, яка становить єдність закономірно розташованих і взаємопов’язаних підсистем. Ознаками системи можна вважати такі:

- наявність підсистем (результат взаємодії елементів);

- наявність у підсистемах найпростіших одиниць, тобто елементів, які ії складають;

- наявність системоутворюючих та зворотних зв'язків, які об'єднують підсистеми в єдину систему;

- наявність достатньої цілісності, ознакою якої може бути виникнення бажаного нового результату, який з'являється завдяки взаємосприянню підсистем.

Система криміналістичного забезпечення, як і будь-яка соціальна система, є системою 3 деяким числом суб'єктів (індивідами та колективами), причому для кожного з них їх діяльність визначається існуванням інших суб'єктів, між якими відбуваються взаємозалежні дії, які «концентруються» залежно від того, наскільки великою є згода щодо досягнення загальних цілей, нормативно-правових умов, пізнавальних очікувань тощо. Різноманітні підходи вчених до формулювання цієї категорії, окрім раніше зазначених аспектів, показують, що само по собі криміналістичне забезпечення може вважатись, за деякими винятками, соціальним інститутом, оскільки єдиним «вигодоотримувачем» буде суспільство.

Описуючи зміст системи криміналістичного забезпечення, ми підходимо з точки зору системного підходу, який, будучи одним з головних напрямів методології спеціального наукового пізнання, сприяє адекватному формулюванню сутності проблеми, що досліджується, і вибору ефективних шляхів ії вирішення.

Так, Є.І. Зуєв визначає зміст криміналістичного забезпечення діяльності з розслідування злочинів за допомогою таких елементів:

1) «організована система інформації, яка полегшує своєчасне, цілеспрямоване й ефективне залучення даних криміналістики для розкриття злочинів; 
2) достатнє забезпечення слідчих, працівників органів дізнання науково-технічними засобами, наявність у них відповідних знань, умінь і навичок використання таких засобів;

3) цілеспрямована система впровадження досягнень криміналістики в практичну діяльність» $[5$, c. $10-11]$.

На думку В.В. Матвієнка, «криміналістичне забезпечення практики розслідування злочинів є іманентно суттєвою ознакою криміналістики та полягає у виявленні потреб слідчої практики та всебічному озброєнні працівників правоохоронних органів дієвими криміналістичними рекомендаціями, які забезпечують оптимізацію розслідування злочинів» [6, с. 53].

П.Д. Біленчук визначив «елементами криміналістичного забезпечення розслідування злочинів такі:

- інформаційне забезпечення слідчо-оперативної групи в «польових умовах»;

- типове програмування невідкладних слідчих (розшукових) дій, організаційних і оперативно-пошукових заходів як одна з форм планування розслідування;

- належний рівень організації розслідування злочинів» [7, с. 379-380].

При цьому В.І. Галаган вбачає у структурі криміналістичного забезпечення три елементи, що у сукупності найбільш повно його характеризують, а саме застосування криміналістичних знань, набуття криміналістичної освіти, ефективне використання криміналістичної техніки [8, с. 74].

В.В. Лисенко зазначає, що «криміналістичне забезпечення діяльності правоохоронних органів щодо виявлення та розслідування злочинів становить певну систему, яка містить такі елементи: блок криміналістичних рекомендацій (як організаційного, тактичного, так і методичного характеру); блок підготовки відповідних кадрів (спеціальної криміналістичної освіти); блок технічного й інформаційного забезпечення процесу виявлення, розслідування та запобігання злочинам» [9, с. 11].

О.С. Рубіс у монографії «Основи теорії криміналістичного забезпечення діяльності прокурора у сфері боротьби зі злочинністю» зазначив, що «під час здійснення регульованого впливу прокурор повинен повною мірою використовувати криміналістичні методи у своїй безпосередній діяльності, а також контролювати криміналістичний зміст діяльності суб'єктів боротьби зі злочинністю під час здійснення процесуального керівництва щодо виявлення і доказування злочинів. < . >> зміст криміналістичної складової частини діяльності прокурора (iї етапи, форми, тактичні прийоми та засоби тощо) слід розглядати як основу механізму процедурної реалізації його наглядової функції з процесуального керівництва цими процесами» [10, с. 4].

Цікаву конструкцію запропонував I.В. Пиріг, який, аналізуючи погляди вчених на проблему визначення змісту поняття забезпечення розслідування кримінальних правопорушень, виокремив такі види.

1. «Залежно від стадії кримінального процесу: забезпечення досудового розслідування; судового розгляду; провадження в суді апеляційної та касаційної інстанцій; виконання судових рішень; провадження у Верховному суді України; провадження за нововиявленими обставинами.

2. Залежно від галузі знань: кримінально-процесуальне; кримінально-правове; криміналістичне; оперативно-розшукове; психологічне.

3. Стосовно окремих видів злочинів: забезпечення розслідування насильницьких, корисливо-насильницьких; злочинів проти власності; у сфері господарської діяльності тощо.

4. Стосовно окремих процесуальних дій: забезпечення проведення слідчих (розшукових) дій; оперативно-розшукових заходів; експертних досліджень; таємниці досудового слідства; безпеки учасників кримінального провадження, прав і свобод людини; профілактики злочинів тощо.

5. За змістом: науково-методичне; правове; матеріально-технічне; інформаційне, організаційне, кадрове тощо» [11, с. 16].

Загалом підтримуючи цю позицію, вважаємо, що незалежно від запропонованих у п. п. 1, 2, 3, 4 видів криміналістичного забезпечення його зміст є універсальним і лише залежно від його виду підсистеми (елементи) системи застосовуються у більшому чи меншому ступенях.

Ми вважаємо, що криміналістика має розширити традиційні межі уявлення про ії предмет та об'єкт шляхом вирішення додаткових питань, які постійно стають перед практикою, позитивне вирішення яких сприяє вдосконаленню діяльності органів кримінальної юрисдикції з протидії злочинності. До того ж до компетенції криміналістики мають належати такі питання, над розробленням яких працювали вчені-криміналісти, які розширюють традиційне уявлення про зміст цієї науки:

- нормативно-правова основа дій вищезазначених осіб та підрозділів, а саме наявність нормативно-правової бази їх діяльності (законів, підзаконних актів, міжнародно-правових договорів) та визначення напрямів їх удосконалення (К.В. Чаплинський);

- наявність технічних засобів, за допомогою яких посадові особи правоохоронних органів виявляють ознаки злочинів, які би сприяли їх розслідуванню (А.Ф. Волинській, В.Ю. Шепітько);

- організаційно-кадровий аспект, який містить дані про навички та вміння посадових осіб, які будуть встановлювати ознаки злочину, наявність відповідних підрозділів правоохоронних органів, які би організовували роботу з виявлення та розслідування злочинів (К.В. Антонов, В.Д. Берназ, К.В. Чаплинський);

- наявність інформаційно-методичної підтримки діяльності уповноважених посадових осіб 3 виявлення і розслідування злочинів (І.О. Ієрусалімов, С.Д. Лук’янчиков, В.Ю. Шепітько) [12, с. 110-115]. 
Отже, на наш погляд, систему, що аналізується, треба розглядати як впорядковану сукупність об'єктів, об'єднаних будь-якими системними зв'язками, що призначені для досягнення чітко визначеної мети найкращим чином. Системний зв'язок - це комплексне поняття, що обумовлює існування декількох структур, за допомогою яких можна описати особливості будь-якої системи, зокрема системи криміналістичного забезпечення.

Будуючи уявлення про поняття системи, яка сприяє виявленню, досудовому розслідуванню та судовому розгляду кримінальних правопорушень органами кримінальної юрисдикції, маємо виокремити такі групи складових частин методологічної схеми:

- «характеристика діяльності: особливості, принципи, умови, норми діяльності;

- логічна структура діяльності: суб'єкт, об'єкт, предмет, форми, засоби, методи, результат діяльності;

- структура діяльності в часі: фази, стадії, етапи діяльності» [13, с. 24].

Досліджуючи зазначену категорію, ми виходимо з того, що у наукових працях використовуються такі слова, як «поняття», «категорія», «термін», які фактично є синонімами: «(от лат. categoria, от гр. kategorikos = утверждающий) - 1) научное понятие, выражающие наиболее общие и существенные связи явлений действительности»[14, с. 315]; «2. наук. Родове поняття, що означає розряд предметів, явищ і т. ін. або їх важливу ознаку» [15, с. 229].

Під поняттям розуміють таке: «одна із форм мислення, результат узагальнення суттєвих ознак об'єкта дійсності» [16, с. 566]; «мысль, фиксирующая существенные свойства, связи и отношения предметов и явлений. < ..> Различают: содержание П. - совокупность фиксированных в нем признаков предметов» $[17$, с. 949].

При цьому у науковому обігу для визначення понять використовується слово «термін». Відповідно до Нового тлумачного словника української мови, термін - це «1. слово або словосполучення, що означає чітко окреслене спеціальне поняття якої-небудь галузі науки, техніки, мистецтва, суспільного життя тощо» $[18$, с. 512$]$. При цьому під визначенням ми розуміємо «формулювання, вислів, у якому розкривається зміст чого-небудь, його істотні ознаки, наукове означення» [19, с. 289].

В наукових роботах учених надані критерії чи домінантні властивості терміна, яким він має відповідати: «1) системність; 2) однозначність у межах однієї терміносфери; 3) наявність дефініції; 4) точність; 5) стилістична нейтральність» [20, с. 128-131].

Виходячи з етимології (походження) слів, якими ми хочемо визначити поняття, зважаючи на функції системи, що досліджується, виходимо з того, що вона (категорія) повинна відображати в собі узагальнення необхідних складових частин, що сприяли би боротьбі зі злочинністю, а в ііі основу слід покласти, з одного боку, поняття діяльності їі суб’ єктів, з іншого боку, загальний стан як результат цієї діяльності. При чому, як раніше нами зазначалося, «функції системи криміналістичного забезпечення не повинні суперечити функціям криміналістики» [21, с. 166].

Питання тлумачення категорії, що аналізується, є дискусійним. Так, учені вбачають можливість вирішення наукової проблеми через визначення цієї категорії як «науково-технічні засоби» [22], «інформаційне забезпечення» [23; 24], «наукове забезпечення» [25, с. 108-111], «науково-методичне забезпечення» [26, с. 5-11], «інформаційно-довідкове забезпечення» [27], «тактичні основи забезпечення» [28].

При цьому, на нашу думку, слід погодитись із висновком А.Я. Ерєкаєва про категоріальне співвідношення деяких вищезазначених понять: «Говоря о соотношении технико-криминалистического и в целом криминалистического обеспечения, следует учитывать, что первое есть не что иное, как элемент второго и соотносится с ним как частное и общее. Следовательно, и то, и другое в их основе одинаково характеризуются по структуре, охватывающей по своему содержанию правовое, научно-методическое и кадровое (криминалистическая подготовка кадров) обеспечение» [29, с. 13-14].

Таким чином, виходячи з того, що родовим поняттям, яке загалом характеризує напрям системної діяльності органів кримінальної юрисдикції з виявлення, досудового розслідування кримінальних правопорушень для прийняття остаточного рішення у кримінальних провадженнях є криміналістика, а також враховуючи те, що криміналістика як практична діяльність є синтетичною, вважаємо, що категорія, яка аналізується, з урахуванням раніше зазначених домінантних властивостей терміна може бути визначена саме як криміналістичне забезпечення.

Формулюючи визначення категорії, сучасні вчені-криміналісти розглядають предмет наукового дослідження криміналістичного забезпечення у таких двох аспектах: у статиці - як систему, у динаміці - як діяльність.

Так, Р.С. Бєлкін, В.Г. Коломацький, В.Ю. Сокол [30], Л.П. Паламарчук [31, с. 1, 2], В.В. Лисенко $[32$, с. $7-8,12]$, Д.Ю. Стригун [33, с. 3-4] та інші науковці пропонують розуміння криміналістичного забезпечення як системи.

3.І. Кірсанов [34, с. 10-11], К.С. Сгоров [35], В.А. Волинский [36], В.В. Матвієнко [37], Ж.В. Удовенко [38, с. 146], О.І. Чучукало [39, с. 148], К.С. Поджаренко [40, с. 6-7] та інші вчені розглядають криміналістичне забезпечення як діяльність.

Окрему думку свого часу запропонував В.Г. Коломацький, а саме розуміння криміналістичного забезпечення як «системы внедрения в практическую деятельность»[41, с. 62], яку підтримав В.О. Образцов 
у такому вигляді: «представление должностным лицам правоохранительных органов, которые профессионально ведут борьбу с преступностью, научной продукции, которая способствует повышению эффективности решения задач, которые стоят перед потребителями такой продукции» [42, с. 25].

В.Г. Лісогор, надаючи визначення, фактично об’єднав розуміння криміналістичного забезпечення як системи та як діяльності, зазначивши, що «криміналістичне забезпечення збереження таємниці досудового слідства включає в себе комплексні взаємопов'язані заходи: 1) організаційного характеру; 2) технічного характеру; 3) спрямовані на розроблення та впровадження тактичних прийомів і методів збереження таємниці під час проведення слідчих дій» [43, с. 17].

Досліджуючи проблеми техніко-криміналістичного забезпечення розслідування злочинів, I.O. Ієрусалімов зауважив, що його «правомірно розглядати в основі методологічної основи діяльності та удосконалення як власне методів і засобів криміналістичної техніки, так і підвищення ефективності їх використання у процесі розслідування злочинів. У цій системі проявляються і реалізуються закономірні взаємозумовленості, взаємозв' язки у вирішенні організаційних, правових, науково-технічних, методичних проблем криміналістичної техніки» [44, с. 224].

На думку А.С. Колодіної, «система криміналістичного забезпечення - це відображення (реалізація) в практичній діяльності взаємопов'язаних, функціональних елементів у виконанні певних завдань. До системи такого забезпечення належать теоретичні розробки науки; технічні засоби криміналістики; тактичні прийоми та рекомендації; криміналістичні методики; методики розслідування окремих видів злочинів» $[45$, c. 216$]$.

Таким чином, незважаючи на різноманітність та багатогранність наукових поглядів учених-криміналістів на категорію, що досліджується, іiі зміст та визначення, ми вбачаємо їх єдність у напрямі діяльності уповноважених державних органів та органів кримінальної юрисдикції.

В контексті наукової проблеми, що досліджується, В.В. Ліпинський як приклад системної діяльності органів адміністративної юрисдикції назвав таке: «митниці ДФС під час виконання покладених на них завдань взаємодіють 3 правоохоронними органами. Під час виявлення ознак порушень митних правил, а також виявлення майна, яке не має власника або власник якого невідомий, митниці ДФС взаємодіють 3 підрозділами охорони державного кордону Державної прикордонної служби України. У разі виявлення під час здійснення митного контролю та інших заходів, що здійснюються органами доходів і зборів ознак правопорушень, розслідування яких не належить до повноважень органів доходів і зборів, митниці ДФС зобов' язані письмово повідомляти про це відповідні правоохоронні органи. Правоохоронні органи зобов'язані письмово повідомляти митниці про виявлені ними порушення митних правил або контрабанду» [46, с. 76].

При цьому спорідненим із криміналістичним забезпеченням є оперативно-розшукове (розвідувальне) забезпечення, яке, на думку В.В. Варави, «є важливою передумовою ефективного виконання завдань щодо запобігання та протидії контрабанді, боротьби з порушеннями митних правил» [47, с. 129].

Враховуючи позиції, що були висловлені науковцями, ми доходимо висновку, що криміналістичне забезпечення розслідування кримінальних правопорушень включає такі складові частини:

- сукупність напрямів забезпечення, які проводяться у порядку, визначеному законодавством, та суб’єктами, уповноваженими на здійснення правоохоронної діяльності;

- засоби, використання яких сприятиме виявленню ознак кримінальних правопорушень та їх розслідуванню;

- нормативні умови, за якими відбувається діяльність 3 виявлення ознак кримінальних правопорушень; дикції.

- методичне та інформаційне забезпечення правоохоронної діяльності органів кримінальної юрис-

Висновки з дослідження і перспективи подальших розвідок у цьому напрямі. Таким чином, виходячи з результатів аналізу наукових думок вчених-криміналістів та завдань, способів і цілей цієї діяльності, можемо визначити категорію, що аналізується, як «криміналістичне забезпечення».

Так, категорії, що аналізується, властива така сукупність критеріїв:

- сувора визначеність кола державних органів, діяльність яких спрямована на «криміналістичне забезпечення»;

- визначеність кола дій, яким спеціально уповноважені особи реалізують імперативну вимогу щодо забезпечення;

- можливість проведення вищезазначених дій лише для забезпечення кримінальних процесуальних дій;

- криміналістичне забезпечення лише в такий спосіб і в такій формі, які передбачені чинним законодавством, яке регулює діяльність правоохоронних органів 3 протидії кримінальним правопорушенням.

На нашу думку, система криміналістичного забезпечення органів кримінальної юрисдикції складається $з$ таких підсистем, як нормативно-правове, організаційно-кадрове, технічне та інформаційно-методичне забезпечення, які повністю охоплюють потреби органів кримінальної юрисдикції з виявлення кримінальних правопорушень, розслідування відповідних проваджень та їх судового розгляду. 
Центральне місце в системі криміналістичного забезпечення посідає нормативно-правове забезпечення, яке встановлює не лише правила поведінки кожного суб'єкта криміналістичного забезпечення, але й умови та способи їх одночасної діяльності.

\section{Список використаних джерел:}

1. Філософський словник соціальних термінів / заг. ред. В.П. Андрущенко. Київ ; Харків : Корвін, 2002. $672 \mathrm{c}$.

2. Берталанфи Л. фон. Общая теория систем - обзор систем и результатов. Системные исследования : ежегодник. Москва, 1969. С. 19-24.

3. Философский энциклопедический словарь. Москва : Инфра-М, 2005.

4. Берталанфи Л. фон. История и статус общей теории систем. Системные исследования : ежегодник. Москва, 1972.

5. Зуев Е.И. Криминалистику - на уровень современных задач борьбы с преступностью. Актуальные вопросы использования достижений науки и техники в расследовании преступлений органами внутренних дел (вопросы криминалистики) : труды Академии МВД СССР. Москва : [б. и.], 1990. С. 10-11.

6. Матвієнко В.В. Криміналістичне забезпечення методики розслідування злочинів : дис. ... канд. юрид. наук : спец. 12.00.09. Київ, 1999. 210 с.

7. Біленчук П.Д., Лисиченко В.К., Клименко Н.І. та ін. Криміналістика. 2-ге вид., випр. і доп. Київ : Атіка, 2001. 544 c.

8. Галаган В.І. Сутність криміналістичного забезпечення розкриття злочинів. Проблеми пенітенціарної теорії і практики. 2001. № 6. С. 74.

9. Лисенко В.В. Криміналістичне забезпечення діяльності податкової міліції (теорія і практика) : монографія. Київ : Логос, 2004. 324 с.

10. Рубис А.С. Основы теории криминалистического обеспечения деятельностью прокурора в сфере борьбы с преступностью : монография. Минск, 2006. 416 с.

11. Пиріг І.В. Теоретико-прикладні проблеми експертного забезпечення досудового розслідування : монографія. Дніпропетровськ : Дніпропетровський державний університет внутрішніх справ ; Ліра ЛТД, 2015. $432 \mathrm{c}$.

12. Карнаухов О.В. Криміналістичне забезпечення розслідування кримінальних правопорушень. Митна справа. 2013. № 1 (85). Ч. 2. Кн. 1. С. 110-115.

13. Новиков А.М., Новиков Д.А. Методология. Москва : СИН-ТЕГ, 2007. 668 с.

14. Булыко А.Н. Современный словарь иностранных слов. 2-е изд., испр. и доп. Москва : Мартин, $2005.848 \mathrm{c}$.

15. Новий тлумачний словник української мови : у 4 т. Т. 2 / укл. В.М. Яременко, О.С. Сліпушко. Київ : Аконіт, 1998. $911 \mathrm{c.}$

16. Новий тлумачний словник української мови : у 4 т. Т. 3 / укл. В.М. Яременко, О.С. Сліпушко. Київ : Аконіт, 1998. $927 \mathrm{c}$.

17. Новый энциклопедический словарь. Москва : Рипол классик, 2005. 1455 с.

18. Новий тлумачний словник української мови : у 4 т. Т. 4 / укл. В.М. Яременко, О.С. Сліпушко. Київ : Аконіт, 1998. $941 \mathrm{c.}$

19. Новий тлумачний словник української мови : у 4 т. Т. 1 / укл. В.М. Яременко, О.С. Сліпушко. Київ : Аконіт, 1998. $911 \mathrm{c}$.

20. Вискушенко С.А. Термін як базовий елемент фахової комунікації. Вісник Житомирського державного університету. 2015. Вип. 2 : Філологічні науки. С. 128-131.

21. Карнаухов О.В. Завдання та функції криміналістичного забезпечення розслідування кримінальних правопорушень. Вісник АМСУ. Серія «Право». 2015. № 2 (15). С. 166.

22. Гончаренко В.И. Научно-технические средства в следственной практике. Киев : Высшая школа, изд. при КГУ, 1984. 152 с.

23. Попов Ю.В. Совершенствование информационного обеспечения следственной деятельности органов внутренних дел на основе использования методов информатики : автореф. дисс. ... канд. юрид. наук : спец. 12.00.09. Киев, 1989.

24. Лук'янчиков С.Д. Інформаційне забезпечення розслідування злочинів : дис. ... докт. юрид. наук : спец. 12.00.09. Киев, 2005.

25. Ищенко А.В. Научное обеспечение организации борьбы с хищениями социалистичечкой собственности. Правовые и спецчиальные средства охраны социалистической собственности. Харьков, 1989. C. $108-111$.

26. Бахін В.П., Лисиченко В.К. Проблеми науково-методичного забезпечення слідчої діяльності. Теоретичні та практичні проблеми використання можливостей криміналістики $і$ судової експертизи у розкритті і розслідуванні злочинів. Київ, 1996. С. 5-11. 
27. Бірюков В.В. Теоретичні основи інформаційно-довідкового забезпечення розслідування злочинів : монографія. Луганськ : Луганський державний університет внутрішніх справ ім. Е.О. Дідоренко, 2009.

28. Чаплинський К.О. Тактичні основи забезпечення досудового розслідування : дис. ... докт. юрид. наук : спец. 12.00.09. Дніпропетровськ, 2011.

29. Эрекаев А.Я. Криминалистическое обеспечение раскрытия и расследования вооруженных разбоев : дисс. ... канд. юрид. наук : спец. 12.00.09. Москва, 2003. 211 с.

30. Сокол В.Ю. Тактико-криминалистическое обеспечение раскрытия и расследования преступлений (методол. и орг. аспекты) : дисс. ... канд. юрид. наук : спец. 12.00 .09 ; Академия управления МВД РФ, Москва, 1998, 188 с

31. Паламарчук Л.П. Криміналістичне забезпечення розслідування незаконного втручання в роботу електронно-обчислювальних машин (комп’ютерів), систем та комп'ютерних мереж : автореф. дисс. ... докт. юрид. наук : спец. 12.00.09 ; Академія адвокатури України. Київ, 2005. 21 с.

32. Лисенко В.В. Проблеми криміналістичного забезпечення розслідування податкових злочинів : автореф. дис. ... докт. юрид. наук : спец. 12.00.09 ; НУВСУ. 2006. 35 с.

33. Стригун Д.Ю. Техніко-криміналістичне забезпечення розкриття та розслідування контрабанди наркотичних засобів : дис. ... канд. юрид. наук : спец. 12.00.09 ; НАВСУ. 2011. 150 с.

34. Кирсанов 3.И. Система общей теории криминалистики. Москва : Академия МВД РФ, 1992. 172 с.

35. Егоров К.С. Проблемы криминалистического обеспечения судебного следствия : дисс. ... канд. юрид. наук : спец. 12.00.09. Москва, 1994. 232 с.

36. Волынский В.А. Технико-криминалистическое обеспечение раскрытия и расследования преступлений : пособие. Москва : ВНИИ МВД РФ, 1994. 80 с.

37. Матвієнко В.В. Криміналістичне забезпечення методики розслідування злочинів : дис. ... канд. юрид. наук : спец. 12.00.09. Київ, 1999. 260 с.

38. Удовенко Ж.В. Криміналістичне забезпечення процесу доказування на досудовому слідстві : дис. ... канд. юрид. наук : спец. 12.00.09 ; НАВСУ. 2004. 205 с.

39. Чучукало O.I. Процесуальне та криміналістичне забезпечення доказування на судових стадіях кримінального процесу України : дис. ... канд. юрид. наук : спец. 12.00.09. Київ, 2004. 199 с.

40. Поджаренко К.С. Криміналістичне забезпечення розкриття і розслідування злочинних порушень прав інтелектуальної власності : автореф. дис. ... канд. юрид. наук : спец. 12.00.09 ; КНУ імені Тараса Шевченка. Київ, 2009. 24 с.

41. Коломацкий В.Г. Криминалистическое обеспечение деятельности органов внутренних дел по расследованию преступлений. Криминалистика : в 3 т. Т. 1 : История, общая и частные теории. Москва : Изд-во Академии МВД России, 1995. 162 с.

42. Образцов В.А. Криминалистика : учебник / под ред. В.А. Образцова. Москва, 1997. 250 с.

43. Лісогор В.Г. Криміналістичне забезпечення збереження таємниці досудовогослідства : автореф. дис. ... канд. юрид. наук : спец. 12.00.09 ; НАВСУ. 2003. 21 с.

44. Ієрусалімов І.О., Приходько Ю.П. Поняття та завдання техніко-криміналістичного забезпечення розслідування злочинів. Прикарпатський юридичний вісник. 2015. № 3 (9). Т. 2. С. 224.

45. Колодіна А.С. Принципи криміналістичної методики у діяльності з розслідування злочинів : дис. ... канд. юрид. наук : спец. 12.00 .09 ; Національний університет «Одеська юридична академія». 2016. $216 \mathrm{c}$

46. Ліпинський В.В. Щодо деяких питань взаємодії органів державної фіскальної служби України та Державної прикордонної служби України під час виявлення ознак порушень митних правил. Правова позииія. 2019. № 2 (23). С. 70-77.

47. Варава В.В. Удосконалення оперативно-розшукового та митного законодавства у контексті проблем викриття кримінальних правопорушень у митній сфері. Правова позищія. 2016. № 1. С. 126-131. 
УДК 343.326

DOI https://doi.org/10.32836/2521-6473.2020-4.17

\author{
О. О. Кирбят'єв, кандидат юридичних наук, \\ докторант Національної академії внутрішніх справ
}

\title{
СУБ'ЄКТИВНА СТОРОНА СКЛАДІВ ЗЛОЧИНІВ, ПЕРЕДБАЧЕНИХ СТАТТЯМИ 342 ТА 345 КК УКРАЇНИ
}

У статті досліджено суб'єктивну сторону складів злочинів, передбачених статтею 342 та статтею 345 КК України. Аргументовано, щзо опір та погроза як злочин з формальним складом можуть бути вчинені лише з прямим умислом. Його інтелектуальний момент характеризується усвідомленням суспільної небезпеки посягання, яке включає розуміння винним двох обов'язкових моментів: по-перше, опір вчиняється саме представникові влади, праиівникові правоохоронного органу, державному виконавцую, члену громадського формування або військовослужбовиеві, по-друге, ці особи перебувають при виконанні покладених на них законом функиій. Вольовий момент полягає у бажанні винного перешкодити виконанню потерпілим своїх обов'язків. Визначено, щя під час вчинення кримінального правопорушення у вигляді погрози вбивством, насильством або знищенням чи пошкодженням майна щзодо працівника правоохоронного органу, а також щзодо його близьких родичів у зв'язку з виконанням циим працівником службових обов'язків суб'єкт злочину передбачає, щуо оскільки вчинювані ним дї̈ є суспільно небезпечними, то вони можуть потягнути певні негативні зміни, пов'язані із заподіянням шкоди суспільним відносинам, щчо забезпечують охорону професійної діяльності прачівників правоохоронних органів. 3 'ясовано, щзо на практиці, як правило, або формально зазначається, щчо особа, яка вчинила кримінальне правопорушення діяла умисно (без уточнення виду умислу), або визначається, що умисел суб'єкта кримінального правопорушення є прямим, проте детально не розкриваються причини такого умовиводу. Зроблено висновок, щзо суб'єктивній стороні складу злочину, передбаченого частиною 4 статті 345 КК України, притаманна виключно умисна форма вини. Здебільшого вона виражається у вигляді прямого умислу, проте іноді (якще діяння виражається у вчиненні організованою групою погрози вбивством, насильством або знищенням чи пошкодженням майна щзодо працівника правоохоронного органу, а також щзодо його близьких родичів у зв'язку з виконанням ичим працівником службових обов'язків) допускаємо можливість того, щзо умисна форма вини може бути виражена у вигляді непрямого умислу.

Ключові слова: право, обов'язки, відповідальність, злочин, покарання, повага, працівники правоохоронних органів, професійна діяльність.

O. O. Kyrbiat'iev. The subjective side of the corpus delict under articles 342 and 345 of the Criminal Code of Ukraine

The article examines the subjective side of the crimes under Art. 342 and Art. 345 of the Criminal Code of Ukraine. It is argued that resistance and threat, as a crime with a formal composition, can be committed only with direct intent. His intellectual moment is characterized by awareness of the public danger of encroachment, which includes the perpetrators' understanding of two obligatory points: first, that resistance is made to a government official, law enforcement officer, state executor, member of a public formation or serviceman, and second, that these persons are in the performance of the functions assigned to them by law. The willpower is the desire of the perpetrator to prevent the victims from fulfilling their responsibilities. It is determined that when committing a criminal offense in the form of threat of murder, violence or destruction or damage to property against a law enforcement officer, as well as against his close relatives in connection with the performance of official duties, the subject of the crime provides that because their actions are socially dangerous, they can lead to certain negative changes associated with harm to public relations, ensuring the protection of professional activities of law enforcement officers. It is found that in practice, as a rule, either formally states that the person who committed a criminal offense acted intentionally (without specifying the type of intent), or it is determined that the type of intent of the subject of the criminal offense - direct, but not detailed the reasons for such an inference are revealed. It is concluded that the subjective side of the crime under Part 4 of Art. 345 of the Criminal Code of Ukraine are characterized by exclusively intentional form of guilt. In the vast majority of cases, it is expressed in the form of direct intent, however, in some cases (if the act is expressed in an organized group threat of murder, violence or destruction or damage to property of a law enforcement officer and his close relatives in connection with this employee duties) allow the possibility that the intentional form of guilt may be expressed in the form of indirect intent.

Key words: law, duties, responsibility, crime, punishment, respect, law enforcement officers, professional activity.

Постановка проблеми. Конституція України у статті 17 проголосила, що захист суверенітету і територіальної цілісності України, забезпечення ії економічної та інформаційної безпеки є найважливішими функціями держави, справою всього Українського народу. Забезпечення державної безпеки і захист державного кордону України покладаються на відповідні військові формування та правоохоронні органи держави, організація і порядок діяльності яких визначаються законом.

Таке положення Основного Закону свідчить про те, що забезпечення належного функціонування суспільства є першочерговим завданнями самих її членів, які мають не тільки права, але й певні обов’ язки.

(C) О. О. Кирбят'єв, 2020 
Єдина згадка про правоохоронні органи в Конституції України свідчить про їх роль у забезпеченні державної безпеки. Водночас неможливо громадянам України надреалізовувати свої права, забуваючи про обов'язки, адже це призводить до кризи поваги до влади, а стосовно працівників правоохоронних органів - неможливості належного виконання ними своїх професійних обов'язків.

Аналіз останніх досліджень і публікацій. Методологічним підгрунтям досягнення проголошеної мети є наукові праці українських учених, зокрема роботи П.П. Андрушка, М.І. Бажанова, О.М. Бандурки, Ю.В. Бауліна, В.С. Батиргареєвої, І.Г. Богатирьова, В.М. Бурдіна, С.Б. Гавриша, В.О. Глушкова, В.К. Грищука, Н.О. Гуторової, Л.М. Демидової, С.Ф. Денисова, Т.А. Денисової, О.М. Джужи, О.О. Дудорова, О.О. Житного, В.П. Смельянова, В.М. Карчевського, О.В. Козаченка, М.Й. Коржанського, В.В. Кузнецова, В.М. Куца, О.М. Литвака, О.М. Литвинова, С.Я. Лихової, В.К. Матвійчука, П.С. Матишевського, М.І. Мельника, В.А. Мисливого, А.А. Музики, В.О. Навроцького, Ю.В. Нікітіна, А.М. Орлеана, В.І. Осадчого, С.О. Письменського, А.В. Савченка, В.В. Сташиса, С.Л. Стрельцова, В.М. Трубникова, В.О. Тулякова, В.І. Тютюгіна, С.В. Фесенка, П.Л. Фріса, М.І. Хавронюка, П.В. Хряпінського, Г.В. Чеботарьової, В.В. Шаблистого, В.I. Шакуна, С.С. Яценка. Водночас ознаки суб'єктивної сторони злочинів, що посягають на професійну діяльність працівників правоохоронних органів, є фактично малодослідженою проблемою. Одними 3 них є статті 342 та 345 КК України. України.

Метою статті є розгляд суб'єктивної сторони складів злочинів, передбачених статтями 342 та 345 КК

Виклад основного матеріалу. Виключно умисною формою вини також характеризується суб’єктивна сторона кримінальних правопорушень, передбачених частинами 2, 3 статті 345 КК України «Погроза або насильство щодо працівника правоохоронного органу». Так, у диспозиції цих норм законодавець прямо зазначає, що для кваліфікації діянь за цими нормами необхідно, щоб тілесні ушкодження відповідної тяжкості були заподіяні суб'єктом злочину виключно умисно.

Щодо виду умислу, то, на думку науковців, суб'єктивна сторона будь-якого кримінального правопорушення, передбаченого статтею 345 КК України, характеризується у формі умислу, вид умислу є виключно прямим [1, с. $230 ; 2$, с. $273 ; 3$, с. 271$]$.

На практиці суди, як правило, або прямо не розкривають вид умислу, або апріорі роблять висновок про те, що форма вини суб’єкта кримінального правопорушення, передбаченого статтею 345 КК України, виражається у формі прямого умислу.

Наприклад, у вироку Обухівського районного суду Київської області від 16 листопада 2017 р. по справі № 372/568/17 зазначено, що суб’ єктивна сторона злочину, передбаченого частиною 2 статті 345 КК України, характеризується тільки умисною виною. Крім того, для суб'єктивної сторони цього злочину характерним $\epsilon$ прямий умисел, поєднаний зі спеціальним мотивом, а саме з нанесенням працівникові правоохоронного органу тілесних ушкоджень саме у зв'язку з виконанням ним своїх службових обов’язків [4].

Цей випадок яскраво демонструє факт того, що суд детально не розглядає вид умислу, а лише декларує його обов’язкову наявність у складі названого кримінального правопорушення.

Незважаючи на це, нами виявлено три випадки, коли у судових вироках за статтею 345 КК України згадувався непрямий вид умислу. Так, у вироку Шаргородського районного суду Вінницької області від 27 грудня 2012 р. по справі № 230/4071/12 зазначається, що допитаний у судовому засіданні підсудний ОСОБА_5 винуватим себе у вчиненні злочину визнав частково, не заперечував факту вчинення злочину за вищенаведених обставин, розкаявся у скоєному, просив його суворо не карати, врахувати, що злочин він вчинив з непрямим умислом та попросив пробачення у потерпілих [5].

Думається, навряд чи цей випадок можна розглядати прикладом вчинення злочину, передбаченого частиною 2 статті 342 КК України з непрямим умислом, оскільки названий вид умислу прямо не був встановлений судом, а лише називався самим суб' єктом кримінального правопорушення.

Для того щоби зробити остаточний висновок щодо виду умислу у цій справі, доречно розглянути саму картину злочину. Зокрема, у вироку зазначено таке: «до ОСОБА_10 підбіг ОСОБА_5 який, перебуваючи у стані алкогольного сп'яніння, умисно, задля спричинення тілесних ушкоджень працівникові правоохоронного органу у зв'язку з виконанням останнім його службових обов'язків, наніс з розмахом удар ногою в ділянку голови» [5].

Без сумніву, наведене свідчить про те, що особа все ж таки діяла з прямим умислом, адже, наносячи з розмахом акцентований удар в ділянку голови правоохоронця, вона не тільки усвідомлювала суспільно небезпечний характер свого діяння (дії або бездіяльності) та передбачала його суспільно небезпечні наслідки, але й бажала (а не допускала) їх настання.

Натомість інші два випадки є менш очевидними щодо визначення виду умислу. У вироку Дарницького районного суду м. Києва від 21 лютого 2020 р. по справі № 753/3644/17 зазначено, що задля зникнення з місця пригоди, діючи умисно, перебуваючи за кермом зазначеного транспортного засобу, ОСОБА_2 почала рух на транспортному засобі марки "Mercedes Benz", державний номерний знак НОМЕР_1. Задля припинення правопорушення ОСОБА_2, ОСОБА_1, діючи згідно зі статтею 23 Закону України «Про національну поліцію», схопилась руками за раму транспортного засобу через відкрите вікно лівих передніх дверцят 
транспортного засобу та почала висловлювати ОСОБА_2 законну вимогу зупинити транспортний засіб. Проте ОСОБА_2, розуміючи, що автомобіль є підвищеним джерелом небезпеки та усвідомлюючи, що він рухається по проїжджій частині з інтенсивним рухом транспортних засобів, а інспектор УПП у м. Києві ОСОБА_1 перебуває при виконанні своїх службових обов'язків, ігноруючи законні вимоги інспектора ОСОБА_1 зупинитись, продовжила керувати зазначеним транспортним засобом під час того, як остання трималась за відкрите вікно лівих передніх дверцят автомобіля. Крім цього, ОСОБА 2 на зазначеному автомобілі почала змінювати смугу руху в лівий бік, де знаходилась ОСОБА_1, та набирати швидкість. Через ці дії ОСОБА_2 потерпіла ОСОБА_1 вдарилась об автомобіль “Mercedes Benz”, державний номерний знак HOMEP_1, яким керував обвинувачений, внаслідок чого потерпіла ОСОБА_1 отримала легкі тілесні ушкодження у вигляді синців по передній поверхні лівої гомілки в середній третині, передній поверхні лівого гомілково-ступневого суглобу. В подальшому ОСОБА_2 зупинила автомобіль марки “Mercedes Benz”, державний номерний знак НОМЕР_1 [6].

У запропонованій ситуації досить складно стверджувати, що, завдаючи тілесних ушкоджень працівнику поліції, особа, яка вчинила злочин, усвідомлювала суспільно небезпечний характер своїх дій, передбачала настання внаслідок їх вчинення небезпечних наслідків та бажала їх настання. В цьому разі, на нашу думку, більш доречно стверджувати, що суб’єкт кримінального правопорушення скоріше свідомо допускав настання цих наслідків.

У цьому випадку суд дійшов такого висновку. Так, у названому вироку зазначено, що твердження сторони захисту про те, що обвинувачений не мав умислу на спричинення потерпілій особі тілесних ушкоджень, тому його дії в гіршому разі можуть бути кваліфіковані за статтею 185 КУпАП, суд вважає неспроможними, оскільки в ході судового розгляду достовірно встановлено, що ОСОБА_2, керуючи джерелом підвищеної небезпеки, достовірно знаючи, що їй інкримінують вчинення адміністративного правопорушення, не погоджуючись 3 діями поліцейських та усвідомлюючи, що потерпіла особа виконує свої службові обов'язки і тримається рукою за водійське вікно, рушила з місця зупинки, та, чуючи крики потерпілої особи через відкрите вікно, стала збільшувати швидкість, виконуючи маневр перестроювання ліворуч - у бік, де знаходилась потерпіла, не могла не передбачити, щзо остання внаслідок ї̈ злочинних дій могла не тільки отримати легке тілесне ушкодження, але й тілесні ушкодження більш тяжкого ступеня (курсив наш О. К.). Наведені обставини вчиненого злочину, на думку суду, свідчать про те, що обвинувачений усвідомлював, щзо може заподіяти шкоду здоров 'ю потерпілої особи, передбачав такі наслідки та свідомо припускав їх настання, щзо підтверджує наявність в обвинуваченого непрямого умислу на вчинення інкримінованого йому злочину (курсив наш - О. К.) [6].

Вважаємо, що висновки суду є цілком логічними, отже, описана у вироку ситуація прямо доводить факт того, що такий обов'язковий елемент суб'єктивної сторони кримінальних правопорушень, передбачених частинами 2, 3 статті 345 КК України, може бути виражений виключно у формі умислу, вид умислу може бути як прямим, так і непрямим.

Можливість наявності в діях суб’єкта кримінального правопорушення, передбаченого частиною 2 статті 345 КК України, непрямого умислу допускається у вироку Бориспільського міськрайонного суду Київської області від 19 березня 2014 року по справі № 1-кп/359/96/2014p, у якому суд дійшов висновку про те, що різниця в показах обвинуваченого та потерпілого щодо частини тіла, якою обвинувачений наніс удар, не впливає на кваліфікацію дій обвинуваченого, оскільки, як зазначає сам обвинувачений, ці дії були вчинені з непрямим умислом (курсив наш - О. К.) [6], що не виключає його вину [7].

Таким чином, суд прямо не визначає наявний у діях злочинця вид умислу, адже в цьому випадку він не впливає на кваліфікацію діяння. Водночас суд опосередковано допускає, що в діях особи міг бути непрямий умисел.

Крім того, на дисертаційному рівні В.Ю. Коломійцем було доведено, що кримінальні правопорушення, передбачені статтями 121-125 КК України, можуть бути вчинені виключно умисно. Вид же умислу допускається як прямий, так і непрямий [8, с. 153].

Звісно, склади цих кримінальних правопорушень суттєво відрізняються від складів злочинів, передбачених частинами 2, 3 статті 345 КК України (насамперед, основним безпосереднім об'єктом кримінального правопорушення), проте низка наявних між ними спільних рис (особливо щодо умисного заподіяння тілесних ушкоджень особі) дає змогу спрямувати сформований В.Ю. Коломійцем висновок у площину суб'єктивної сторони умисного заподіяння працівникові правоохоронного органу чи його близьким родичам побоїв або відповідної тяжкості тілесних ушкоджень у зв'язку з виконанням цим працівником службових обов'язків (частина 2 або частина 3 статті 345 КК України). При цьому наявність спеціального мотиву у складах останніх кримінальних правопорушень жодним чином не спростовує цю думку, адже наявність такого елементу суб’єктивної сторони допускається у кримінальних правопорушеннях як 3 прямим, так і непрямим умислом.

Отже, на підставі викладеного допускаємо, що всупереч поширеній у науці кримінального права думці вина як обов'язковий елемент суб'єктивної сторони складів злочинів, передбачених частинами 2, 3 КК України, може бути виражена у вигляді не тільки прямого, але й непрямого умислу. 
Щодо злочину, передбаченого частиною 1 статті 345 КК України, нагадаємо, що це суспільно небезпечне діяння вчені, як правило, відносять до кримінальних правопорушень із формальним складом. Альтернативні ж позиції щодо цього виглядають дискусійними, адже, як слушно зауважує В.В. Шаблистий, всі спроби віднести злочини та кримінальні проступки у вигляді погрози вчинення певного діяння (наприклад, погрозу вбивства) до кримінальних правопорушень із матеріальним чи усіченим складом грунтуються на прагненні порушити класичний поділ усіх складів кримінальних правопорушень (за особливостями конструкції) на формальні, матеріальні та усічені [9, с. 9].

Цей фактор особливості конструкції складу кримінального правопорушення, передбаченого частиною 1 статті 345 КК України, є досить важливим щодо розгляду такої суб'єктивної ознаки, як вина, адже в науці кримінального права домінуючою є думка про те, що для кримінальних правопорушень із формальним складом характерною є вина у вигляді прямого умислу, але не тому, що суб'єкт не має психічного ставлення до наслідків діяння. Навпаки, саме наявність такого ставлення до наслідків визначає зміст ставлення до діяння. До речі, саме тому законодавча формула умислу є універсальною і не потребує змін та уточнень [10, с. 39].

Враховуючи це, робимо умовивід, що злочин, передбачений частиною 1 статті 345 КК України, характеризується виключно умисною формою вини, вид умислу є прямим.

Думається, в цьому разі слушними є доповнення Р.В. Вереши про те, що під час вчинення кримінальних правопорушень з формальним складом суб'єкт передбачає, що, оскільки вчинювані ним діяння є суспільно небезпечними, вони можуть потягти за собою певні негативні зміни, перш за все в об'єкті злочинного посягання. Отже, у злочинах та кримінальних проступках із формальним складом встановлення ознаки передбачення грунтується на усвідомленні суспільно небезпечного характеру вчинюваних дій і передбаченні внаслідок їх вчинення, негативних змін у сфері охоронюваних кримінальним законом об’ єктів [11, с. 214].

3 наведеного випливає, що під час вчинення кримінального правопорушення у вигляді погрози вбивством, насильством або знищенням чи пошкодженням майна щодо працівника правоохоронного органу, а також щодо його близьких родичів у зв'язку з виконанням цим працівником службових обов'язків суб' єкт злочину передбачає, що оскільки вчинювані ним дії є суспільно небезпечними, то вони можуть потягнути за собою певні негативні зміни, пов’язані із заподіянням шкоди суспільним відносинам, що забезпечують охорону професійної діяльності працівників правоохоронних органів.

Розглянемо також вину як обов'язковий елемент суб'єктивної сторони складу злочину, передбаченого частиною 4 статті 345 КК України. Вище нами було встановлено, що злочини, передбачені частинами 2, 3 статті 345 КК України, можуть бути вчинені у формі умислу, вид умислу є як прямим, так і непрямим, тоді як кримінальне правопорушення у вигляді погрози вбивством, насильством або знищенням чи пошкодженням майна щодо працівника правоохоронного органу, а також щодо його близьких родичів у зв'язку з виконанням цим працівником службових обов'язків, вчиняється виключно у вигляді прямого умислу.

3 огляду на це логічно припустити, що діям, передбаченим частиною 1 статті 345 КК України, вчиненим організованою групою, також характерний виключно прямий умисел, а діям, передбаченим частинами 2,3 , вчиненим організованою групою, - як прямий, так і непрямий умисел.

Втім, склад кримінального правопорушення, передбаченого частиною 4 статті 345 КК України, має суттєву особливість: він вчиняється організованою групою.

Нагадаємо, відповідно до частини 3 статті 28 КК України, кримінальне правопорушення визнається вчиненим організованою групою, якщо в його готуванні або вчиненні брали участь декілька осіб (три й більше), які попередньо зорганізувалися у стійке об'єднання для вчинення цього та іншого (інших) кримінальних правопорушень, об'єднаних єдиним планом з розподілом функцій учасників групи, спрямованих на досягнення цього плану, відомого всім учасникам групи [12].

Висновки 3 дослідження і перспективи подальших розвідок у цьому напрямі. Отже, для того, щоб остаточно сформувати умовивід щодо виду умислу у складі кримінального правопорушення, передбаченого частиною 4 статті 345 КК України, необхідно визначитись щодо можливості вчинення кримінального правопорушення у складі організованої групи з непрямим умислом.

Для цього скористаємось напрацюваннями А.А. Вознюка, який довів, що умисна участь у вчиненні умисного злочину передбачає, що кожен співучасник усвідомлює суспільно небезпечний характер діяння (дії або бездіяльності), що вчиняє разом з іншими співучасниками, передбачає його суспільно небезпечні наслідки й бажає їх настання. Мотиви діяльності цього суб'єкта можуть бути різними. Співучасники діють здебільшого з прямим умислом і лише іноді виконавець (співвиконавець) або пособник має непрямий умисел [13, с. 9].

На підставі наведеного можна дійти висновку про те, що суб'єктивній стороні складу злочину, передбаченого частиною 4 статті 345 КК України, притаманна виключно умисна форма вини. Здебільшого вона виражається у вигляді прямого умислу, проте іноді (якщо діяння виражається у вчиненні організованою групою погрози вбивством, насильством або знищенням чи пошкодженням майна щодо працівника правоохоронного органу, а також щодо його близьких родичів у зв'язку з виконанням цим працівником службових обов'язків) допускаємо можливість того, що умисна форма вини може бути виражена у вигляді непрямого умислу. 
Щодо кримінального правопорушення у вигляді опору представникові правоохоронного органу (частини 2, 3 статті 342 КК України), то науковці у галузі кримінального права мають єдину точку зору стосовно форми та виду вини у складі цих злочинів [14, с. 674; 15, с. 717; 16, с. 268]. Так, зазначається, що суб'єкт цих злочинів діє виключно з умисною формою вини, вид умислу є прямим.

Повністю погоджуємось із думкою А.С. Габуди, який, дослідивши склади кримінальних правопорушень, передбачених статтею 342 КК України, дійшов висновку про те, що опір як злочин 3 формальним складом може бути вчинено лише з прямим умислом. Інтелектуальний його момент характеризується усвідомленням суспільної небезпеки посягання, яке включає розуміння винним двох обов' язкових моментів: по-перше, опір вчиняється саме представникові влади, працівникові правоохоронного органу, державному виконавцю, члену громадського формування або військовослужбовцеві, по-друге, ці особи перебувають при виконанні покладених на них законом функцій. Вольовий момент полягає у бажанні винного перешкодити виконанню потерпілим своїх обов'язків [16, с. 13].

Такої ж думки щодо виду умислу у складах злочинів, передбачених частинами 2, 3 статті 342 КК України, дотримуються суди. Так, нами не виявлено жодного випадку, в якому б суд установив, що суб'єкт злочину у вигляді опору представнику правоохоронного органу діяв із непрямим умислом. На практиці, як правило, або формально зазначається, що особа, яка вчинила кримінальне правопорушення діяла умисно (без уточнення виду умислу), або визначається, що вид умислу суб'єкта кримінального правопорушення є прямим, проте детально не розкриваються причини такого умовиводу.

Названі вище факти дають підстави погодитись із думкою про те, що вина як ознака суб'єктивної сторони кримінального правопорушення, передбаченого статтею 342 КК України, виражається у формі умислу, вид умислу є прямим.

\section{Список використаних джерел:}

1. Кримінальне право України. Особлива частина : навчальний посібник. Одеса : ОДУВС, 2013. 336 с.

2. Кузнецов В.В., Савченко А.В., Плугатир В.С. Кримінальне право України: теоретичний курс та практикум : навчальний посібник/ за заг. ред. В.Я. Горбачевського. Київ : Атіка, 2005. 378 с.

3. Савченко А.В., Шуляк Ю.Л. Кримінальне право України. Загальна та Особлива частини (у схематичних діаграмах) : навчальний посібник. Київ : Центр учбової літератури, 2015. 312 с.

4. Вирок Обухівського районного суду Київськоїобласті від 16 листопада 2017 р. по справі№ 372/568/17// Єдиний державний реєстр судових рішень. URL: http://www.reyestr.court.gov.ua/Review/70297685.

5. Вирок Шаргородського районного суду Вінницької області від 27 грудня 2012 р. по справі № 230/4071/12 // Сдиний державний реєстр судових рішень. URL: http://www.reyestr.court.gov.ua/ Review/28428973.

6. Вирок Дарницького районного суду м. Києва від 21 лютого 2020 р. по справі № 753/3644/17 // Єдиний державний реєстр судових рішень. URL: http://www.reyestr.court.gov.ua/Review/87751917.

7. Вирок Бориспільського міськрайонного суду Київської області від 19 березня 2014 р. по справі № 1-кп/359/96/2014p // Єдиний державний реєстр судових рішень. URL: http://www.reyestr.court.gov.ua/ Review/37697933.

8. Коломієць В.Ю. Кримінальна відповідальність за заподіяння тілесних ушкоджень : дис. ... канд. юрид. наук : спец. 12.00.08. Дніпро, 2019. 237 с.

9. Шаблистий В.В. Кримінальна відповідальність за погрозу вбивством : автореф. дис. ... канд. юрид. наук : спец. 12.00.08. Дніпропетровськ, 2010. 20 с.

10. Куц В.М., Бондаренко О.М. Зміст вини у злочинах з формальним складом. Вісник Національної академії прокуратури Украӥни. 2009. № 3. С. 36-40.

11. Вереша Р.В. Проблеми суб'єктивної сторони складу злочину : дис. ... докт. юрид. наук : спец. 12.00.08. Київ, 2017. 583 с.

12. Кримінальний кодекс України : Закон України від 5 квітня 2001 р. № 2341-III. Законодавство Украӥни / Верховна Рада Украӥни. URL: http://zakon3.rada.gov.ua/laws/show/2341-14.

13. Вознюк А.А. Кримінально-правові ознаки організованих груп і злочинних організацій : монографія. Київ : Національна академія внутрішніх справ, 2015. 192 с.

14. Кримінальний кодекс України : науково-практичний коментар. 9-те вид., перероб. та доп. / відп. ред. Є.Л. Стрельцов. Харків : Одіссей, 2013. 912 с.

15. Кримінальний кодекс України. Науково-практичний коментар : у 2 т. / за заг. ред. В.Я. Тація, В.П. Пшонки, В.І. Борисова, В.І. Тютюгіна. 5-те вид., доп. Харків : Право, 2013.

16. Габуда А.С. Кримінально-правова характеристика складу опору особам, наділеним владними повноваженнями : автореф. дис. ... канд. юрид. наук : спец. 12.00.08. Львів, 2012. 21 с. 
УДК 343.132

DOI https://doi.org/10.32836/2521-6473.2020-4.18

О. М. Скрябін, доктор юридичних наук, доцент, доцент кафедри кримінального права, процесу та криміналістики Класичного приватного університету

\section{СЛІДЧІ ДІЇ ЯК ОСНОВНИЙ ЗАСІБ ЗБИРАННЯ ДОКАЗІВ У КРИМІНАЛЬНОМУ ПРОВАДЖЕННІ}

У статті розкрито сутність поняття «слідчі дї̈» згідно з чинним Кримінальним процесуальним кодексом Украӥни, представлено підходи сучасних науковиів до визначення поняття та мети реалізаиіі слідчих дій. Збирання доказів у кримінальному провадженні є комплексним поняттям, яке складається із системи дій, які спрямовані на виявлення доказів, їх зберігання та перевірку. Слідчі дї - це заходи, до яких входять пошукові, пізнавальні та посвідчувальні прийоми, щчо проводяться уповноваженими кримінально-процесуальним законом суб'єктом у встановленому порядку для кожного кримінального провадження. Метою слідчих дій є виявлення, закріплення фактичних даних та відомостей про ӥх джерела для отримання доказів та їх перевірки у кримінальному провадженні. Також метою реалізаиії слідчих дій може бути створення умов для реалізачії іншої слідчої дї (наприклад, отримання зразків для експертизи). Зазначено, щзо у визначенні поняття доказів має бути відображена їх иільова спрямованість на дослідження доказів у кримінальному провадженні під час вивчення й фіксації їх індивідуальних ознак і виявленні на них слідів злочину або в разі проведення експертизи. Учинному КПК України визначено поняття негласних слідчих дій. Негласність слідчих дій проявляється в особливому порядку проведення таких дій, підготовки до їх проведення, а також фіксащії, зберігання результатів, щзо були отримані, та їх перевірки. Інформація щуодо негласних слідчих дій є утаємниченою як від тих осіб, відносно яких проводяться слідчі діï, так і від усіх інших осіб, а саме співробітників органів досудового розслідування, оперативних підрозділів, посадових осіб правоохоронних та інших державних органів, усіх громадян, котрі не причетні до підготовки та проведення конкретних негласних слідчих дій. До слідчих дій характеру належать обшук, пред'явлення до впізнання, огляд, допит, ексгумація трупа, слідчий експеримент, освідчування особи, проведення експертизи. Аналіз чинного законодавства щодо визначення поняття слідчих дій виявив, щзо недоліком є відсутність чіткого унормування переліку слідчих дій.

Ключові слова: слідчі дії, кримінальне провадження, докази, кримінальний процес, розшукові дї, Кримінальний прочесуальний кодекс Украӥни.

\section{O. M. Scriabin. Investigative actions as the main means of collecting evidence in criminal proceedings}

The article reveals the essence of the concept of investigative actions according to the current Criminal Procedure Code of Ukraine, presents the approaches of modern scientists to define the concept and purpose of investigative actions. The collection of evidence in criminal proceedings is a complex concept that consists of a system of actions aimed at identifying, storing and verifying evidence. Investigative actions are measures that include search, cognitive and identification techniques conducted by a subject authorized by the criminal procedure law in the prescribed manner for each criminal proceeding. The purpose of investigative actions is to identify, consolidate factual data and information about their sources to obtain evidence and verify them in criminal proceedings. Also, the purpose of the implementation of investigative actions may be to create conditions for the implementation of another investigative action (for example, obtaining samples for examination). The purpose of investigative actions or their complex may be the formation of the desired investigative situation. It is noted that the definition of evidence should reflect their focus on the study of evidence in criminal proceedings in the study and recording of their individual characteristics and identify traces of crime or in the case of examination. The current CPC of Ukraine defines the concept of covert investigative actions. The secrecy of investigative actions is manifested in a special order of such actions, preparation for their conduct, as well as recording, storage of the results obtained and their verification. Information on covert investigative actions is confidential, both from those persons under investigation, as well as from all other persons - employees of pre-trial investigation bodies, operational units, law enforcement officials and other state bodies, all citizens, etc., who are not involved in preparation and conduct of specific covert investigative actions. Investigative actions of the nature include search, identification, examination, interrogation, exhumation of the corpse, investigative experiment, identification, examination. An analysis of the current legislation on the definition of investigative actions revealed that the disadvantage is the lack of a clear standardization of the list of investigative actions.

Key words: investigative actions, criminal proceedings, evidence, criminal proceedings, search actions, Criminal Procedure Code of Ukraine.

Постановка завдання. Сучасне українське суспільство прагне до розвитку демократії, встановлення прозорості діяльності державних органів та гуманізації суспільства, тому однією з важливих задач $є$ створення умов, за яких усі винні будуть покарані відповідно до вчиненого злочину, а всі невинні не будуть притягненні до відповідальності. Ця позиція закріплена у ст. 2 Кримінального процесуального кодексу України (далі - КПК) [1].

(C) О. М. Скрябін, 2020 
Важливим аспектом у виконанні цього завдання є проведення досудового розслідування слідчим. Обов'язком слідчого є пізнання обставин, за яких відбулося скоєння кримінального правопорушення, за допомогою проведення слідчих дій, негласних слідчих дій та інших процесуальних дій відповідно до повноважень, закріплених у КПК України.

Отже, важливим та необхідним сьогодні є дослідження слідчих дій у кримінальному провадженні як основного засобу збирання доказів. Така необхідність зумовлена суспільними змінами, розвитком способів і засобів збирання доказів, що впливає на діяльність слідчого й проведення досудового розслідування.

Аналіз останніх досліджень і публікацій. Проблематика визначення поняття слідчих дій, розгляд слідчих дій в аспекті засобу збирання доказів у кримінальному провадженні була об'єктом досліджень таких учених, як Р.С. Бєлкін [2], Ю.М. Грошевий [3], О.В. Капліна [4], В.Т. Нор [5], Ю.Д. Федоров [6], С.А. Шейфер [7]. Проте слід зазначити, що нині необхідними є актуалізація та удосконалення наявних знань щодо дослідження слідчих дій як засобу збирання доказів у кримінальному провадженні, що пов'язано із суспільними змінами, які впливають на проведення досудового розслідування.

Мета статті полягає в аналізі та дослідженні слідчих дій як основного засобу збирання доказів у кримінальному провадженні.

Виклад основного матеріалу. Відповідно до чинного КПК України (ст. 93), збирання доказів стороною обвинувачення відбувається шляхом проведення слідчих (розшукових) дій та негласних слідчих (розшукових) дій; витребування та отримання від органів державної влади, органів місцевого самоврядування, підприємств, установ та організацій, службових та фізичних осіб речей, документів, відомостей, висновків експертів, висновків ревізій та актів перевірок; одержання доказів на території іноземної держави в результаті здійснення міжнародного співробітництва під час кримінального провадження; проведення інших процесуальних дій, передбачених КПК [1]. Основним способом збирання доказів стороною обвинувачення $\epsilon$ проведення слідчих (розшукових) дій і такого їх різновиду, як негласні слідчі (розшукові) дії.

Слідчі дії, як зазначає М.А. Погорецький, - це заходи, які складаються із сукупності пошуково-пізнавальних та посвідчувальних прийомів, проводяться уповноваженими кримінальним процесуальним законом суб' єктом у визначеному для кожного з них порядку задля виявлення й закріплення фактичних даних і відомостей про їх джерела для отримання доказів у кримінальному провадженні та їх перевірки [8, с. 393].

Слідчі дії в широкому розумінні визначає А.Б. Соловйов, який говорить, що це детально регламентовані законом кримінально-процесуальні дії, які включають до своєї структури систему взаємопов’язаних операцій, зумовлених наявністю і своєрідним поєднанням у кожному з них загальнонаукових методів пізнання, що мають аспекти, які взаємодіють та спрямовані на збирання та перевірку доказів задля вирішення завдань кримінального судочинства [9, с. 27].

Білоруський учений Г.В. Федоров, досліджуючи слідчі дії, зазначає, що у визначенні має відображатись їх цільова спрямованість на дослідження доказів, що має місце, наприклад, під час огляду предметів і документів, коли вивчаються і фіксуються їх індивідуальні ознаки й виявлені на них сліди злочину, а також у разі призначення й проведення експертизи. При цьому Г.В. Федоров звертає увагу на те, що ні збирання, ні перевірка доказів не можуть включати їх дослідження, під час якого встановлюються фактичні дані про властивості доказів та їх взаємозв'язки.

Акцентуючи увагу на криміналістичній сутності слідчих дій як тактичних засобів протидії злочинності, а також вказуючи на спадковість наукових теорій, він пропонує визначати слідчі дії як різновид процесуальних дій, що становлять комплекс передбачених і суворо регламентованих кримінально-процесуальним законом заходів компетентних осіб, котрі спрямовані на збирання, дослідження, перевірку й використання доказів [6, с. 89-91].

B.I. Галаган, досліджуючи слідчі дії розшукового характеру, відносить до них допит, обшук, огляд, під час проведення яких зусилля слідчого спрямовані на встановлення тих обставин (пошук особи, яка вчинила злочин, його матеріальних слідів), які у ході подальшого розслідування дають змогу приймати правильні процесуальні й тактичні рішення [10, с. 34].

Визначаючи мету слідчих дій, Р.С. Бєлкін вказував на те, що такою метою може бути створення умов для проведення іншої слідчої дії (наприклад, отримання зразків для порівняльного дослідження або виїмки документів для їх подальшого експертного дослідження). Метою слідчих дій або їх комплексу, на його думку, може бути формування потрібної слідчої ситуації [2, с. 673-674].

Порівнюючи новий КПК України 2012 року з попереднім, зазначаємо, що новацією є визначення в ньому в окремій ст. 246 КПК України такого виду процесуальних дій, як негласні слідчі (розшукові) дії. Це різновид слідчих (розшукових) дій, відомості про факт та методи проведення яких не підлягають розголошенню, за винятком випадків, передбачених КПК України [1].

Так, Д.М. Халупенко говорить, що негласність слідчих (розшукових) дій означає особливий порядок їх підготовки, проведення та зберігання й використання отриманих результатів у режимі прихованості до певного часу від інших осіб, які не причетні до їх проведення. До того ж утаємниченими такі відомості мають бути не лише від осіб, стосовно яких проводяться ці дії, але й від будь-яких інших осіб, зокрема співробітників органів досудового розслідування, оперативних підрозділів, посадових осіб правоохоронних та інших 
державних органів, пересічних громадян, які не задіяні в підготовці та проведенні конкретних негласних слідчих (розшукових) дій, навіть якщо вони беруть участь в інших процесуальних заходах із проведення досудового розслідування у конкретному кримінальному провадженні [11, с. 2].

Слідчі (розшукові) дії, на думку Д.Б. Сергєєвої та О.С. Старенького, не є лише заходами, що складаються із сукупності пошуково-пізнавальних і посвідчувальних прийомів. Слідчі (розшукові) дії $є$ також розшуковим заходом, на що прямо вказується в низці норм КПК України (ст. ст. 223, 227, 236). Пошук і розшук не є синонімами, оскільки пошук полягає у шуканні чого-небудь за певними властивостями [12, с. 1099], а розшук полягає у виявленні чи знаходженні чогось уже відомого [12, с. 1273].

Розшукова спрямованість слідчих (розшукових) дій проявляється під час установлення місцезнаходження відомих осіб, оголошених у розшук, і різних об'єктів, предметів, місцезнаходження яких невідоме, невідомих потерпілих, свідків, місцезнаходження викраденого майна, отримання іншої інформації, яка невідома, проте має значення для кримінального провадження [13].

Сутність будь-якої слідчої (розшукової) дії в системі засобів збирання, дослідження, оцінювання й використання доказів під час кримінально-процесуальної діяльності визначається насамперед ії тактичними можливостями забезпечення пізнавальних процесів та отримання доказової інформації, тому вибір процесуальною особою певної чи іншої слідчої (розшукової) або негласної слідчої (розшукової) дії залежить від установленого джерела інформації та різновиду відображення слідів, що мають чи можуть мати доказове значення [11, с. 4].

Аналізуючи чинне законодавство щодо визначення поняття «слідчі дії», С.О. Пришляк зазначає, що вперше у КПК України чітко унормовано поняття слідчих (розшукових) дій як дій, спрямованих на отримання (збирання) доказів або перевірку отриманих доказів у конкретному кримінальному провадженні. Чітко у ч. 2 ст. 223 КПК закріплено підстави їх проведення, регламентовано визначення нічного часу, в який заборонено проведення слідчих (розшукових) дій, крім невідкладних випадків, коли затримка в їх проведенні може призвести до втрати слідів кримінального правопорушення чи втечі підозрюваного.

Основною негативною рисою ст. 223 КПК є відсутність вичерпного переліку всіх слідчих (розшукових) дій, що, на наш погляд, доцільно унормувати у окремій їі частині та внести відповідні доповнення. У результаті аналізу статей, що розміщені у главі 20 чинного КПК, ми встановили, що систему слідчих (розшукових) дій становлять такі дії, які спрямовані на отримання (збирання) доказів або перевірку вже отриманих доказів у конкретному кримінальному провадженні, а саме допит (ст. ст. 224-226 КПК) [14, с. 423-424].

I.C. Кіпрач зазначає, що отримання (збирання) доказів як функція слідчих дій є комплексним поняттям і складається із системи дій, спрямованих на виявлення, фіксацію і збереження доказів та їх процесуальних джерел. Сутність процесу збирання доказів полягає у виконанні пошукових операцій згідно з їх кримінально-процесуальною регламентацією, які спрямовані на виявлення слідів злочину, речових доказів тощо, що здійснюється на основі складної розумової діяльності задля встановлення місць можливого знаходження доказів чи визначення кола осіб, у показаннях яких вони можуть міститися.

Слідчі (розшукові) дії своєю метою мають не тільки отримання (збирання) доказів, але й перевірку вже отриманих, що полягає в детальному дослідженні зібраних доказів та їх процесуальних джерел з точки зору їх придатності (належності, достовірності й допустимості) для встановлення обставин, що мають значення для кримінального провадження, отриманні нових для підтвердження або спростування раніше зібраних доказів.

Перевірка як елемент процесу доказування має місце на всіх стадіях кримінального судочинства й тісно пов'язана зі збиранням та оцінкою доказів, їх процесуальних джерел. Вона здійснюється шляхом проведення нових чи додаткових слідчих (розшукових) дій за результатами логічного аналізу й дослідження змісту кожного доказу окремо та їх зіставлення з іншими доказами в кримінальному провадженні. Проте одна й та сама слідча (розшукова) дія за різних обставин справи та на різних етапах досудового розслідування може бути спрямована як на отримання нових доказів, так і на перевірку вже отриманих [15, с. 279].

Також слід зазначити, що застосування словосполучення «слідчі (розшукові) дії» є доволі дискусійним, оскільки слідчі дії та розшукові заходи за своїм змістом, характером, метою й завданнями є різними процесуальними засобами, тому ототожнювати їх, ставити між ними знак рівності некоректно, навіть якщо вони отримали однакове значення у формуванні доказової бази [16, с. 23; 17, с. 293-294].

Д.Б. Сергєєва та О.С. Старенький доходять висновку, що слідчі (розшукові) дії як засоби отримання доказів у кримінальних провадженнях - це заходи, що складаються із сукупності пошуково-пізнавальних, розшукових та посвідчувальних прийомів, проводяться спеціально уповноваженим кримінальним процесуальним законом суб'єктом у визначеному для кожного з них порядку задля виявлення й закріплення фактичних даних і відомостей про їх джерела для отримання доказів у кримінальних провадженнях.

Слід зауважити, що слідчі (розшукові) дії виокремлюються з числа інших процесуальних дій саме властивим їм пізнавальним характером і пошуково-розшуковою спрямованістю, сутність яких полягає у намаганні процесуальної особи виявити (знайти, розшукати) й належним чином зафіксувати у відповідних процесуальних джерелах фактичні дані, що мають значення для кримінального провадження. Саме цей аспект вищезазначеної діяльності підсилив законодавець, уводячи до чинного КПК України дещо змінений 
термін для позначення цих дій, а саме «слідчі (розшукові) дії». Водночас не менш важливою метою слідчих (розшукових) дій є перевірка раніше отриманих у кримінальному провадженні доказів. Усі інші дії слідчого, передбачені КПК України, що прямо не пов'язані з отриманням і перевіркою доказів, прийнято позначати терміном «процесуальні дії слідчого» [13, с. 87-88].

Висновки 3 дослідження і перспективи подальших розвідок у цьому напрямі. Таким чином, отримання доказів є багатоплановим та комплексним поняттям, яке складається 3 комплексу дій, спрямованих на виявлення, фіксацію та збереження доказів у кримінальному провадженні, а також перевірку їх достовірності. Основним способом збирання доказів виступають слідчі дії та негласні слідчі дії у кримінальному провадженні. Реалізація слідчих дій відбувається задля отримання доказів та перевірки тих доказів, що наявні, дослідження слідів кримінального правопорушення, пізнання яких важливе для провадження. Слідчими діями виступають допит, обшук, огляд, освідчування особи, ексгумація трупа, слідчий експеримент, пред’явлення до впізнання, проведення експертизи. Аналіз чинного КПК України показав, що визначення категорії слідчих дій чітко унормовано, а також закріплені підстави для їх проведення. В законодавстві зазначено, що реалізація слідчих дій у нічний час $\epsilon$ можливою лише тоді, коли затримка їх проведення може спричинити втрату слідів злочину чи втечу підозрюваного у провадженні. Проте недоліком чинного законодавства є відсутність чіткого переліку дій, які належать до слідчих дій, що потребує подальшого розгляду та врегулювання.

\section{Список використаних джерел:}

1. Кримінальний процесуальний Кодекс України. Відомості Верховної Ради України (ВВР). 2013. № 9-10, № 11-12, № 13. Ст. 88. URL: https://zakon.rada.gov.ua/laws/show/4651-17 (дата звернення: 05.11.2020).

2. Белкин Р.С. Курс криминалистики : учебное пособие для вузов. 3-е изд. доп. Москва : ЮНИТИ-ДАНА ; Закон и право, 2001. 837 с.

3. Грошевий Ю.М., Мірошниченко Т.М., Хоматов Ю.В. та ін. Кримінальний процес України : підручник для студентів юридичних спеціальностей вищих закладів освіти / за ред. В.М. Хотенця. Харків : Право, 2000. 496 c.

4. Капліна О.В. Збирання доказів сторонами кримінального провадження. Актуальні проблеми доказування у кримінальному провадженні : матеріали Всеукраїнської науково-практичної інтернет-конференції (27 листопада 2013 року, м. Одеса). Одеса, 2013. С. 223-229.

5. Кримінальний процесуальний кодекс України : науково-практичний коментар / за заг. ред. В.Г. Гончаренка, В.Т. Нора, М.Є. Шумила. Київ : Юстініан, 2012. 1224 с.

6. Федоров Г.В. Криминалистические средства противодействия преступности : монография. Минск : Центр охраны труда и промбезопасности, 2007. 277 с.

7. Шейфер С.А. Следственные действия. Система и процессуальная форма. Москва : Юрлитинформ, 2001. 208 c.

8. Погорецький М.А. Функціональне призначення оперативно-розшукової діяльності у кримінальному процесі : монографія. Харків : Арсіс ЛТД, 2007. 576 с.

9. Соловьев А.Б. Доказывание в досудебных стадиях уголовного процесса России. Москва : Юрлитинформ, 2002. $160 \mathrm{c}$.

10. Галаган В.І. Використання у доказуванні результатів негласних слідчих (розшукових) дій. Становлення системи негласного розслідування у кримінально-процесуальному законодавстві України : матеріали круглого столу Національної академії внутрішніх справ (м. Київ, 7 жовтня 2011 року). Київ, 2011. С. $33-36$.

11. Халупенко Д.М. Слідчі (розшукові) дії як пізнавальні засоби слідчого й прокурора за чинним КПК України. Часопис Академї̈ адвокатури України. 2013. № 19. С. 1-6.

12. Великий тлумачний словник сучасної української мови (з дод., доп. та CD) / уклад. і голов. ред. В.Т. Бусел. Київ ; Ірпінь : ВТФ «Перун», 2009. 1736 с.

13. Сергєєва Д.Б., Старенький О.С. Слідчі (розшукові) дії як засоби отримання доказів у кримінальних провадженнях щодо неповнолітніх: до визначення поняття. Вісник кримінального судочинства. 2017. № 1. С. 81-89.

14. Пришляк С.О. Слідчі (розшукові) дії як засоби збирання доказів під час розслідування окремих кримінальних правопорушень. Науковий вісник Львівського державного університету внутрішніх справ. 2013. № 4. C. 417-427.

15. Кіпрач І.С. Визначення поняття слідчих (розшукових) дій. Науковий вісник національної академії внутрішніх справ. 2013. № 2. С. 275-283.

16. Журавель В.А. Слідчі (розшукові) дії як засоби формування доказів за чинним Кримінальним процесуальним кодексом України. Теорія та практика судової експертизи і криміналістики. 2013. № 13. С. $22-30$.

17. Журавель В.А. Вибрані твори. Харків : Апостіль, 2016.704 с. 
УДК 340.137:341.9

DOI https://doi.org/10.32836/2521-6473.2020-4.19

\author{
I. М. Жуков, кандидат юридичних наук, доцент, \\ доцент кафедри міжнародного права \\ Національного юридичного університету імені Ярослава Мудрого
}

\title{
АКТУАЛЬНІ ПИТАННЯ МІЖНАРОДНО-ПРАВОВОГО РЕГУЛЮВАННЯ РОЗРАХУНКОВИХ ВІДНОСИН
}

У статті досліджено деякі аспекти правового регулювання транскордонних розрахункових відносин. Визначено, щз спеиифіка міжнародних розрахункових відносини обумовлена різними чинниками. По-перще, міжнародні розрахункові операції становлять основу міжнародної фінансової системи. По-друге, за допомогою міжнародних розрахункових відносин можуть виконуватись міжнародні комериійні контракти, відображаючи специфіку взаємовідносин як між учасниками зовнішньоекономічної угоди, так і між банком та його клієнтом. Крім того, розрахункові відносини можуть бути підставою для подальших грошових операцій (договір банківського рахунку) або опосередковувати процес передачі иінностей від однієї особи до іншої на умовах повернення (договір позики або кредиту).

Акиентовано увагу на тому, щзо глобалізаційні та інтеграційні процеси впливають на регулювання економічних відносин та розвиток міжнародної фінансової і банківської системі. Такий вплив відбувається шляхом поєднання субстантивного та колізійного методів регулювання.

Уніфікація матеріально-правових норм тісно пов'язана з діяльністю неурядових організацій, щзо спрямована на узагальнення практики ділового обігу, вивчення й систематизачію сформованих звичаїв, формулювання стандартних (типових) форм договорів у сфері міжнародних розрахунків. Констатовано, що окремі форми міжнародних розрахунків врегульовано за допомогою міжнародних актів, у яких матеріально-правове регулювання має переважне значення.

Національне законодавство деяких країн представлено спеціальними колізійними прив'язками, які застосовуються до грошових зобов'язань. Відсутність у національному праві подібних колізійних приниипів може ускладнювати прочес вибору застосовної правової системи та потребує належного регулювання.

Ключові слова: міжнародні розрахункові відносини, форма розрахунків, грошове зобов'язання, грошовий переказ, колізійна норма.

\section{M. Zhukov. Topical issues of international legal regulation of settlement relations}

The paper investigates some aspects of the legal regulation of cross-border settlement relations. It is determined that the specifics of international settlements relations are conditioned to various factors. First of all, international settlement operations form the basis of the international financial system. Secondly, with the help of international settlement relations, international commercial contracts can be performed reflecting the specifics of the relationship both between the parties to the foreign trade agreement and between the bank and its client. In addition, the settlement relations may be the basis for further monetary transactions (bank account agreement), or mediate the process of transferring values from one person to another on repayment terms (loan or credit agreement).

Emphasis is placed on the fact that the processes of globalization and integration affect the regulation of economic relations and the development of the international financial and banking systems. This effect occurs through a combination of substantive and conflict-of-laws methods of regulation.

Unification of substantive norms is closely connected with the activities of non-governmental organizations aimed at generalizing the practice of business turnover, studying and systematizing of established customs, formulating of standard (typical) forms of agreements in the field of international settlements. It is stated that certain forms of international settlements are regulated by international acts in which substantive legal regulation is of paramount importance.

The national laws of some countries are subject to special conflict-of-laws rules that apply to monetary obligations. The absence of such conflicting principles in national law can complicate the process of choosing the applicable legal system and requires proper regulation. rule.

Key words: international settlement relations, form of settlements, monetary obligation, money transfer, conflict of laws

Постановка проблеми. Міжнародна фінансова система являє собою сукупність фінансових ринків і транскордонних фінансових потоків грошового капіталу й передбачає фінансові відносини між різними суб'єктами, що регулюються правовими нормами різних систем права, а саме міжнародної та національних правових систем [1, с. 36]. Саме тому розвиток міжнародної фінансової системи та міжнародних економічних відносин тісно пов'язаний зі станом національних банківських систем, які перебувають у постійній взаємозалежності та взаємодії.

Специфіка міжнародних розрахункових відносини обумовлена там, що, по-перше, міжнародні розрахункові операції становлять основу міжнародної фінансової системи, по-друге, за допомогою міжнародних

(C) I. М. Жуков, 2020 
розрахункових відносин можуть виконуватись міжнародні комерційні контракти, відображаючи специфіку взаємовідносин як між учасниками зовнішньоекономічної угоди, так і між банком та його клієнтом. Крім того, розрахункові відносини можуть бути підставою для подальших грошових операцій (договір банківського рахунку), або опосередковувати процес передачі цінностей від однієї особи до іншої на умовах повернення (договір позики або кредиту). Саме ця особливість пояснює специфіку правового регулювання міжнародних розрахункових відносин і те, що різні галузі права (міжнародне фінансове право, міжнародне економічне право, міжнародне приватне право) відносять їх до предмета свого регулювання.

Аналіз останніх досліджень і публікацій. Питання та проблеми міжнародно-правового регулювання розрахункових відносин відзначали різні вчені, зокрема В.П. Богун, О.Р. Вайцеховська, В.В. Дячек, А.Й. Іванський, Т.А. Латковська, О.Г. Можарін, С.С. Пилипишин, Є.В. Сотченко, І.О. Терещенко, Г.С. Фединяк, В.А. Чубенко. Проте наявність у фінансових правовідносинах іноземного елементу передбачає підпорядкування грошового зобов'язання праву кількох держав та появу типових проблем міжнародного приватного права, таких як конфлікт кваліфікацій, колізійні проблеми транскордонних грошових зобов’язань, вибір валюти платежу, правової природи валютних застережень, що залишає низку питань, які потребують подальших досліджень.

Мета статті полягає у вивченні та аналізі джерел правового регулювання міжнародних розрахункових відносин, а також визначенні напрямів вирішення колізійних проблем.

Виклад основного матеріалу. Розвиток світової економічної та фінансової системи приводить до ефективного залучення у національну економіку іноземних інвестицій у вигляді іноземного капіталу до банківського сектору, наслідком чого є активізація та переформатування транскордонного ринку банківських послуг тощо. Під впливом глобалізаційних та інтеграційних процесів регулювання економічних відносин та міжнародної фінансової і банківської системи відбувається шляхом поєднання матеріально-правового та колізійного методів регулювання. Крім того, у зв'язку з розвитком уніфікації матеріально-правових норм і збільшенням уніфікованих актів для посилення результату гармонізації правового регулювання країни можуть здійснювати послідовні узгоджені дії (наприклад, «процес Ламфалусі» [2]). Також ця уніфікація тісно пов'язана 3 діяльністю неурядових організацій, спрямована на узагальнення практики ділового обігу, вивчення й систематизацію сформованих звичаїв, формулювання стандартних (типових) форм договорів у відповідній сфері. Саме такі норми набувають міжнародного, глобального характеру, суттєво впливають на національну нормотворчу діяльність. Так, за участю міжнародних органів та організацій було розроблено та прийнято Конвенцію УНІДРУА про міжнародний фінансовий лізинг 1988 р., Конвенцію УНІДРУА про міжнародний факторинг 1988 р., Конвенцію про міжнародні переказні векселі і міжнародні прості векселі 1988 р., Конвенцію ООН про використання електронних повідомлень у міжнародних договорах 2005 р., типові (модельні) закони та положення з питань права міжнародної торгівлі, збірники уніфікованих звичаїв, правил і узвичаєнь тощо.

Інтернаціоналізація фінансових відносин, зокрема банківської діяльності, також вимагає необхідності ефективного нагляду за діяльністю іноземних філій та структурних підрозділів фінансових компаній за кордоном. Такий нагляд є можливим завдяки співпраці органів фінансового (банківського) нагляду різних держав. Саме міжнародна (транскордонна) банківська діяльність зумовила появу міжнародного нормативного комплексу для узгодження стандартів банківського регулювання, а також передбачає створення інституційного (утворення органу, в рамках якого здійснюється взаємоузгодження) і нормативного (розроблення та прийняття комплексу нормативних актів, що містять однакові стандарти банківського регулювання) механізмів. Поштовхом для цього став крах у 1974 р. великого західнонімецького банку "Bankhaus Herschtatt" у зв’язку з ризикованими валютними операціями, а спричинена цим перша міжнародна банківська криза привела до створення центральними банками та органами нагляду держав G10 органу міжнародного співробітництва держав у сфері банківського регулювання, відомого сьогодні як Базельський комітет 3 питань банківського нагляду, основним завданням якого є впровадження високих та єдиних стандартів у сферу банківського регулювання та нагляду, які одержують своє відображення в національному законодавстві.

Глобалізаційні процеси в економіці держав - членів СС спонукали до здійснення уніфікації розрахункових відносин на рівні ЄС. Першим кроком до цього стала норма про свободу руху платежів у ч. 2 ст. 63 Договору про функціонування ЄС [3, с. 280]. Наступним важливим актом стала Директива 97/5/€С про грошові перекази від 27 січня 1997 р. [4]. Значні зміни в регулюванні безготівкових розрахунків відбулися з прийняттям Директиви 2007/64/СС про платіжні послуги від 13 листопада 2007 р. [5], яка була змінена Директивою 2015/2366 від 25 листопада 2015 р. [6] і розширила конкуренцію на ринку платіжних послуг, гармонізувавши законодавство про захист прав споживачів та про права й обов'язки надавачів платіжних послуг та їх користувачів. Для забезпечення однакового нагляду за організаціями, які здійснюють платіжні операції з електронними грошима, була прийнята друга Директива ЄС у галузі розрахункових відносин, а саме про електронні грошові кошти. Задля створення єдиної платіжної зони у 2012 р. було прийнято SEPA-регламент ЄC [7], на підставі якого розроблено нові уніфіковані інструменти SЕРА-розрахунків. Регламент визначає правові основи діяльності платіжних та кредитних організацій у сфері надання ними послуг та технічну і юридичну інтеграцію розрахунків з використанням грошових переказів і розрахунків за допомогою прямого дебетування. Цим 
Регламентом визначено правову основу технічної та юридичної інтеграції розрахункових відносин за допомогою прямого дебетування, а також установлено нові вимоги до позначення міжнародного номера банківського рахунку (IBAN), який також запроваджено Україною у систему електронних платежів [8].

Значну роль у сфері регулювання міжнародних фінансових відносин відіграє національне законодавство. Норми національного права, які регулюють фінансові відносини з іноземним елементом, можуть міститися як у законах (наприклад, Закони України «Про Національний банк України» від 20 травня 1999 р. [9], «Про банки і банківську діяльність» від 7 грудня 2000 р. [10], «Про платіжні системи та переказ коштів в Україні» від 5 квітня 2001 р. [11], «Про валюту і валютні операції» від 21 червня 2018 р. [12]), так і у підзаконних нормативних актах, до яких відносять переважно акти Національного банку України (наприклад, Постанови Правління Національного банку України «Про затвердження Інструкції про порядок відкриття і закриття рахунків клієнтів банків та кореспондентських рахунків банків - резидентів і нерезидентів» від 12 листопада 2003 р. № 492 [13], «Про затвердження Положення про порядок реєстрації платіжних систем, учасників платіжних систем та операторів послуг платіжної інфраструктури» від 4 лютого 2014 р. № 43 [14], «Про здійснення операцій з використанням електронних платіжних засобів» від 5 листопада 2014 р. № 705 [15], «Про затвердження Положення про порядок здійснення банками операцій за акредитивами» від 3 грудня 2003 р. № 514).

Розрахункові зобов'язання, виступаючи в ролі складової частини контрактних умов та форми реалізації грошових зобов'язань, являють собою зобов'язання боржника сплатити певні кошти кредитору за отриманий від нього еквівалент. Як правило, закордонні платіжні операції виключають можливість здійснення безпосередніх розрахунків, залучаючи для цього спеціалізовані банківські установи.

Найбільш поширеними формами міжнародних розрахунків виступають банківський переказ, інкасо та розрахунки акредитивами. У міжнародній практиці використовуються також вексельна, чекова та інші форми розрахунків. Слід зауважити, що цей перелік є умовним і жодним чином не відображає класифікацію форм безготівкових розрахунків. Крім того, розрахунки чеками здійснюються банками у порядку інкасо, а розрахунки платіжними дорученнями та інкасові операції являють собою різновиди однієї форми розрахунків.

У національному законодавстві колізійне регулювання розрахункових відносин обмежується положеннями ст. ст. 43 та 44 Закону України «Про міжнародне приватне право» від 23 червня 2005 р. [16]. У законодавстві деяких іноземних держав ці проблеми врегульовані окремими колізійними нормами. Так, §38 Закону про міжнародне приватне право Австрії передбачає можливість застосування до банківських операцій особистого закону кредитної установи, а у відносинах між кредитними установами застосовується особистий закон сторони, яка повинна здійснити виконання [17].

Під час вирішенні колізійної проблеми грошових зобов'язань велике значення має їх класифікація поділ на первинні та вторинні. Первинні регулюються колізійними норми, які передбачені саме для врегулювання відповідних відносин, а до вторинних, як правило, застосовуються колізійні норми основної угоди (купівлі-продажу, перевезення, банківського вкладу тощо), а відповідна специфіка грошових зобов’язань у цій сфері не проявляється.

До колізійних прив'язок у сфері грошових зобов’язань відносять lex monetae (lex pecunia), яка передбачає застосування права тієї країни, платіжним засобом якої виступає відповідна валюта. Саме за цим принципом відповідно до ст. 147 Закону Швейцарії «Про міжнародне приватне право» 1987 р. [18] до грошових зобов’язань застосовується право держави емісії. Зауважимо, що у вітчизняній доктрині колізійна прив’язка lex monetae визнання не отримала.

Разом із формулою lex monetae у міжнародних угодах, вітчизняних та закордонних нормативних актах передбачено інші прив'язки, зокрема закон місця знаходження кредитора (ст. 6.1.6 Принципів УНІДРУА ред. 2016 р.); закон місця платежу (ст. 147 Закону Швейцарії «Про міжнародне приватне право» 1987 р.); внутрішнє право звичайного проживання кредитора, що отримує аліменти (ст. 4 Конвенції про право, що застосовується до аліментних зобов'язань від 2 жовтня 1973 р.); право держави місцезнаходження цедента (ст. 22 Конвенції ООН (ЮНСІТРАЛ) про відступлення дебіторської заборгованості в міжнародній торгівлі від 12 грудня 2001 р.).

У країнах англо-саксонської системи права lex causae застосовується для вирішення питання належності виконання зобов'язання, а lex fori - питання допустимості заліку й укладення угоди про заміну виконання.

Зазначене змушує зробити висновок про звуження можливості застосування принципу автономії волі сторін під час регулювання розрахункових відносин у зовнішньоекономічних угодах.

Найбільш поширеною формою міжнародних розрахунків є банківський переказ, особливістю якого $\epsilon$ те, що клієнт банку дає доручення перевести певну грошову суму зі свого рахунку на рахунок іншої особи або на інший свій рахунок.

Кредитовий переказ використовується тоді, коли перерахування коштів не обумовлено зустрічним рухом товарів, робіт або послуг (здійснення так званих неторгових платежів).

У національному законодавстві така форма розрахунків здійснюється із застосуванням платіжних доручень (ст. ст. 1089-1092 ЦК України, ст. 341 ГК України та ст. 1 Закону України «Про платіжні системи та переказ коштів в Україні», Інструкція про безготівкові розрахунки в Україні в національній валюті [19]). 
Зазвичай під час застосування цієї форми розрахунків учасники зовнішньоекономічної операції перебувають у різних державах і ними, крім самих сторін зовнішньоекономічної угоди, стають банк платника та банк бенефіціара. У МПрП відсутній міжнародно-правовий акт, яким регулюють банківські перекази. Водночас рекомендаційний характер мають документи, які регламентують здійснення банківських операцій 3 переказу коштів, а саме Типовий закон ЮНСІТРАЛ про міжнародні кредитові перекази 1992 р. [20] та Правове керівництво ЮНСІТРАЛ з електронного переведення коштів 1987 р. [21].

Залежно від способу здійснення документообігу банківськими каналами виокремлюють такі види кредитових переказів: поштовий переказ (поштове платіжне доручення), яке надсилається банком авіапоштою; телеграфний переказ (телеграфне або телексне платіжне доручення), що надсилається телеграфом або телексом банку бенефіціара зі вказівкою про сплату коштів бенефіціару; переказ системою SWIFT (SWIFT transfer) - письмове платіжне доручення, яке надсилається міжнародною комп'ютерною мережею зв’ язку.

Базовим документом, який вирішує колізійні проблеми у сфері міжнародних (транскордонних) кредитових переказів, є Типовий закон ЮНСІТРАЛ 1992 р. про міжнародні кредитові перекази, ст. 5 якого зазначає про те, що права й обов'язки, які випливають із платіжного доручення, визначаються на підставі автономії волі, а за відсутності домовленості сторін застосовується право держави банку-одержувача (п. 1).

Під дебетовим переказом (у внутрішніх розрахункових відносинах - розрахунки за інкасовими дорученнями) розуміють форму розрахунків, за якою експортер доручає банку отримати від імпортера суму платежу під час надання товаророзпорядчих документів. Інкасова [22] форма розрахунків регламентується не лише положеннями національного законодавства (Закон України «Про платіжні системи та переказ коштів в Україні» та Інструкція про безготівкові розрахунки в Україні в національній валюті), але й уже згаданими міжнародними звичаєвими нормами, кодифікація яких здійснена МТП у вигляді Уніфікованих правил по інкасо у редакції 1995 р. [23] (Публікація МТП № 522). Інкасування (інкасо) здійснюється банком за дорученням клієнта операцій з розрахунковими та супровідними документами задля одержання платежу або передавання розрахункових та/чи супровідних документів проти платежу або передавання розрахункових та/чи супровідних документів на інших умовах.

Учасниками такої операції є експортер (довіритель) [24], банк-ремітент [25], банк, що здійснює інкасування (банк, який бере участь у виконані доручення), банк, що представляє документи платнику, та платник.

Уніфіковані правила розрізняють чисте інкасо та документарне інкасо. Чисте інкасо стосується інкасування фінансових документів, які не супроводжуються комерційними документами (чеки, векселі); документарне інкасо - це інкасо фінансових документів, які супроводжуються комерційними документами, або інкасо комерційних документів, які не супроводжуються фінансовими.

Інкасова операція починається у банку-ремітента, куди експортер товару передає документи з доданим до них інкасовим дорученням, що містить повні й точні інструкції для банків. Після перевірки правильності оформлення інкасового доручення, комерційних і фінансових документів банк експортера пересилає їх банку, що інкасує у країні імпортера (зазвичай своєму кореспонденту). Банк імпортера сповіщає імпортера та передає йому документи або проти сплати зазначеної у дорученні суми, або проти акцепту векселя (під час надання комерційного кредиту у вексельній формі). Після отримання повідомлення від банку, що інкасує, про зарахування коштів на рахунок банку-ремітента останній здійснює розрахунки з експортером.

Особливість правової природи інкасо відображено у ст. 12 Уніфікованих правил, за якими банк, який здійснює інкасування, несе відповідальність лише за видачу документів платнику проти платежу і не відповідає за платіж або акцепт чи перевірку цих документів. Банк-ремітент повинен утримуватися від обговорення виду та кількості документів, отриманих від банку, що інкасує.

Якщо сторони (експортер та імпортер), укладаючи зовнішньоекономічний контракт, визначають, що платежі за поставлений товар виконуватимуться за допомогою документарного акредитива, то у контракті, як правило, зазначається, який банк відкриває акредитив, через який банк цей акредитив має бути авізований (сповіщений) експортеру, обумовлюється вид акредитива, перелік документів, які має подати експортер для одержання платежу.

Акредитивна форма розрахунків регламентується як нормами національного права (Положення про порядок здійснення банками операцій за акредитивами [26]), так і міжнародними звичаєвими нормами, тобто Уніфікованими правилами та звичаями для документарних акредитивів (редакція 1993 р., публікація МТП № 500 [27], редакція 2007 р., публікація МТП № 600 [28]). Акредитив являє собою договір, за яким банк-емітент за дорученням клієнта (заявника акредитива) або від свого імені проти документів, які відповідають умовам акредитива, зобов'язаний провести платіж на користь бенефіціара або доручає іншому (виконуючому) банку здійснити цей платіж. Характерною рисою акредитива є його абстрактний характер, оскільки відносини сторін за ним юридично не пов'язані із зовнішньоекономічною угодою, за якою з'явилось грошове зобов'язання.

Правовий режим міжнародної акредитивної угоди відрізняється від правового режиму внутрішньої акредитивної угоди. Ця відмінність обумовлена суб'єктним складом внутрішнього та міжнародного акредитивів і може не збігатись. За певних обставин міжнародний акредитив (трансферабельний акредитив) може бути визнаний цінним папером. 
Незначним залишається міжнародно-правове регулювання акредитивних відносин. Сдиною міжнародною угодою, предметом якої виступають виключно міжнародні акредитивні відносини, є Конвенція ООН про незалежні гарантії та резервні акредитиви від 11 грудня 1995 р. [29].

Одним із важливих положень міжнародної акредитивної угоди є принцип суворої відповідності, за яким банк має право відхилити документи, які за зовнішніми ознаками не відповідають умовам акредитива. Вимоги до таких документів містяться як у національному законодавстві (Кодекс торговельного мореплавства України [30]) так і в міжнародних угодах (Міжнародна конвенція про уніфікацію деяких правил про коносамент 1924 р.) і в звичаєвих правилах (Уніфіковані правила та звичаї для документарних акредитивів).

Щодо колізійного регулювання, то міжнародний акредитив регулюється складним комплексом колізійних норм, до яких, зокрема, відносять право країни банку-емітента, яке застосовується до договору між наказодавцем і банком-емітентом і до одностороннього зобов'язання банка-емітента перед бенефіціаром; право країни виконуючого банку, яке застосовується до договору між банком-емітентом і виконуючим банком і договором між банком-емітентом і авізуючим банком.

У міжнародних розрахункових відносинах широке застосування отримали різні види оборотних документів, до яких належать такі фінансові інструменти, як векселі, чеки, депозитні сертифікати. Вексельна форма характеризується тим, що у зовнішньоекономічних відносинах вексель може виступати як борговий цінний папір або як платіжний, розрахунковий чи кредитний інструмент. Крім того, вексельні розрахунки характеризуються абстрактністю та безумовністю, що робить їх самостійним платіжним засобом.

Міжнародно-правове регулювання вексельного обігу характеризується протистоянням двох вексельних систем, а саме женевської та англо-американської. Перша представлена державами, які запровадили у національне законодавство положення Женевських конвенцій 1930 р., тобто Конвенції, якою запроваджено Уніфікований закон про переказні векселі та прості векселі 1930 р. [31], Конвенції про врегулювання деяких колізій законів про переказні векселі та прості векселі 1930 р. [32], Конвенції про гербовий збір стосовно переказних та простих векселів 1930 р. [33]. Це країни, що є переважно державами континентальної Свропи, які приєднались до Конвенцій, та держави, які не підписали їх, але запровадили як моделі власного вексельного законодавства Уніфікований закон.

Англо-американська система представлена Британією, Канадою, США, Австралією та деякими колишніми колоніями, зокрема офшорними зонами, у яких власне вексельне законодавство сформовано на положеннях Закону Великобританії «Про переказні векселі» 1882 p. (Bills of Exchange Act) [34]. Iснує третя група країн, чиє власне вексельне законодавство переважно базується на нормах Комерційного кодексу Франції 1807 р. і яку не можна віднести ні до англо-американської, ні до женевської групи. До кола цих країн належать латиноамериканські держави, Сгипет, Іран, Ліхтенштейн, Таїланд тощо.

Україна у 1999 р. офіційно приєдналась до всіх трьох Женевських вексельних конвенцій 1930 р., особливість їх обігу визначивши Законом України «Про обіг векселів в Україні» від 5 квітня 2001 p. № 2374-III [35]. Женевські вексельні конвенції 1930 р. та закон регулюють випуск, обіг, погашення векселів і стягнення за векселем та регламентують права всіх учасників вексельного обігу.

Хоча вищезазначені акти регламентують вексельні відносини, у галузі міжнародних розрахунків можуть виникати питання про застосовне право щодо розрахунків з використанням векселів, якщо вексель був виданий в одній країні, векселедержателем є компанія, що розташована в іншій державі, а місцем платежу - третя країна. При цьому країни можуть належати до різних груп вексельних систем.

Колізійне регулювання, запроваджене Конвенцією про врегулювання деяких колізій законів про переказні векселі та прості векселі 1930 р., передбачає застосування колізійних принципів особистого закону боржника, місця виникнення вексельного зобов’язання та місця виконання такого зобов’язання.

Крім того, існує безліч національних актів, які базуються на нормах Женевських вексельних конвенцій 1930 р. і передбачають просте відсилання до Конвенції (наприклад, ст. 59 Закону «Реформа італійської системи міжнародного приватного права» 1995 р. [36]). Іноді регулювання вексельних відносин здійснюється за допомогою спеціальних актів, таких як Закон КНР «Про вексель» від 10 травня 1995 р. [37], Закон Великобританії про переказні векселі 1882 р., або за допомогою загальних актів, які містять відповідні колізійні норми (наприклад, Закон Румунії «Про регулювання відносин міжнародного приватного права» 1992 р. № 105 [38]).

Ці акти можуть містити різні за своїм змістом колізійні норми. Зокрема, обсягу колізійних норм стосовно вексельної правосуб’ єктності (ст. 2 Конвенції, ст. 127 Закону Румунії № 105), форми векселя (ст. 3 Конвенції, п. 72 Закону Великобританії «Про переказні векселі» 1882 р., ст. 128 Закону Румунії № 105), зобов’язання акцепту (ст. 4 Конвенції), строків пред’явлення позову в порядку регресу (ст. 5 Конвенції, ст. 129 Закону Румунії № 105), прав вимоги векселедержателя (ст. 6 Конвенції), допустимості часткового акцепту чи часткового платежу (ст. 7 Конвенції, п. 72 Закону Великобританії «Про переказні векселі» 1882 р.), форми і строків протесту (ст. 8 Конвенції, п. 72 Закону Великобританії «Про переказні векселі» 1882 р.), а також наслідків втрати або викрадення векселя (ст. 9 Конвенції) можуть відповідати різні прив'язки, такі як особистий закон векселедавця, закон місця складання (передачі) векселя, закон місця виконання векселя та закон місця вчинення протесту. 
3 огляду на положення Закону України «Про міжнародне приватне право» колізійне регулювання міжнародних вексельних відносин може здійснюватися у такий спосіб: за особистим законом юридичної особи визначається здатність відповідати за вексельним зобов’язанням (ст. 25 Закону України «Про міжнародне приватне право»), право власності на вексель визначається за правом тієї країни, в якій особа перебуває (ст. 38 Закону України «Про міжнародне приватне право»), а форма правочину - за принципом автономії волі або критерієм тісного зв'язку із правочином. Крім того, є можливим субсидіарне застосування колізійних норм, оскільки окремі елементи вексельного зобов'язання можуть бути підпорядковані різним правовим системам, що не виключає застосування приписів ч. ч. 3, 4 ст. 5 Закону України «Про міжнародне приватне право».

Приватно-правові відносини, які виникають у зв’язку з обігом чеку як засобу платіжу, також становлять специфічний предмет міжнародного приватного права та регулюються за допомогою матеріально-правового та колізійно-правового методів регулювання. Як і з вексельним обігом, регулювання цих відносин має комплексний характер та передбачає наявність як національно-правових, так і міжнародно-правових норм.

Подібність правового регулювання вексельних та чекових розрахунків обумовлена наявністю міждержавної уніфікації. Така уніфікація відбулась на підставі Женевських чекових конвенцій 1931 р., а саме Уніфікованого закону про чеки 1931 р. [39], Конвенції, що має на меті вирішення деяких колізій законів про чеки, 1931 р. [40], Конвенції про гербовий збір стосовно чеків 1931 р. [41].

Виокремлюють дві основні системи чекового права, такі як чек за Женевською Конвенцією (документ має автономний статус) та чек англо-американського типу (різновид переказного векселя). «Женевський» чек обов'язково повинен мати чекову мітку, а їі відсутність позбавляє документ властивості чекового оборотного документа.

За англо-саксонською системою права чек являє собою різновид переказного векселя (п. 73 Закону Великобританії «Про переказні векселі» 1882 р. та ст. 3-104 Єдиного комерційного кодексу США [42]). Більш того, Єдиний комерційний кодекс США, на відміну від законодавства країн континентальної Свропи, не містить вимоги про чекову мітку та зазначає, що документ може бути чеком, навіть якщо він поіменований як грошовий переказ (ст. 3-104 Сдиного комерційного кодексу США).

Національне законодавство України не відносить чек до цінних паперів, а відносить його лише до форми безготівкових розрахунків, яка може здійснюватися із застосуванням розрахункових чеків (ст. 1102 ЦК України, ст. 341 ГК України, ст. 3 Закону України «Про цінні папери та фондовий ринок» від 23 лютого 2006 р. [43], п. 1.4 Інструкції про безготівкові розрахунки в Україні в національній валюті).

Хоча Женевські чекові конвенції 1931 р. Україною не ратифіковані, їх зміст враховано під час розроблення та прийняття національних нормативних актів.

Так, Положення про порядок здійснення операцій з чеками в іноземній валюті на території України [44] передбачає можливість здійснення банками та небанківськими фінансовими установами операцій з чеками в іноземній валюті на території України, які емітовані за кордоном і пред’явлені до сплати на території України. Саме тоді можлива ситуація, коли учасником чекових правовідносин буде український суб'єкт, тому з огляду на положення ст. 6 Закону України «Про міжнародне приватне право»є можливим застосування міжнародних договорів, що не вступили в силу, для тієї держави, де знаходиться комерційне підприємство учасника зовнішньоекономічних відносин, у разі підпорядкування розрахункової операції закону держави-учасниці цих договорів. Більш того, згідно 3 п. 3 ст. 59 Закону Італії «Про реформу італійської системи міжнародного приватного права», оборотні документи регулюються правом країни, на території якої вони були випущені, але зобов’язання інші, ніж основне зобов’язання, регулюються правом тієї країни, на території якої кожне з таких зобов'язань було прийнято.

З урахуванням положень Постанови Верховної Ради України «Про порядок тимчасової дії на теритоpiї України окремих актів законодавства Союзу РСР» від 12 вересня 1991 р. № 1545-XII [45] до внутрішньодержавних нормативних актів, які регламентують колізійні питання у чекових відносинах, слід віднести «Положення про чеки», затверджене Постановою ЦВК і РНК СРСР від 6 листопада 1929 р. (у редакції від 25 жовтня 1986 р. [46]). До іноземних внутрішньодержавних актів слід віднести Закон Великобританії «Про переказні векселі» 1882 р., Сдиний комерційний кодекс США тощо. Крім того, необхідно враховувати дію колізійних норм, які загалом регламентують відносини з цінними паперами або регулюють певні їх різновиди, наприклад чеки.

Головною колізійною прив'язкою у сфері транскордонних чекових правовідносин Конвенцією, що має на меті вирішення деяких колізій законів про чеки 1931 р., Положенням про чеки 1929 р. та низкою інших нормативних актів є закон місця видачі чека (lex loci actus).

За нею визначається застосовне право щодо обов'язків чекодавця (закон місця видачі чека), індосанта та аваліста (закон місця вчинення індосаменту або аваля). Водночас якщо форма чека не відповідає вимогам закону місця складання чека, але відповідає вимогам закону місця платежу, то цей документ буде дійсним.

Чекова правосуб'єктність визначається за загальним правилом на підставі особистого закону. Здатність особи бути платником за чеком визначається законом місця платежу. Національні акти, крім зазначе- 
них колізійних приписів, можуть містити інші положення. Так, ст. 35 Закону Республіки Корея «Про колізії законів» 1962 р. визначено вимоги до трасата.

Висновки з дослідження і перспективи подальших розвідок у цьому напрямі. Таким чином, аналіз основних аспектів правового регулювання міжнародних розрахункових відносин дав змогу констатувати, що їх регулювання здійснюється за допомогою єдності міжнародних та національних матеріально-правових і колізійно-правових норм, які іноді мають імперативний характер. Крім того, такі відносини являють собою систему послідовно виконуваних міжнародних та внутрішніх правочинів, які об'єднані єдиною метою, якою є здійснення транскордонних розрахункових операцій, а також здійснюються за участю стабільних суб'єктів (банківські установи та їх клієнти) із застосуванням спеціального стандартизованого документообігу.

\section{Список використаних джерел:}

1. Вайцеховська О.Р. Міжнародний фінансовий правопорядок: теоретичні засади та сучасний стан розвитку : монографія. Чернівці : Друк Арт, 2019. 559 с.

2. Цей процес названо прізвищем одного із його розробників і пов’язаний із реформою у фінансовому секторі СС. Спочатку запропонований механізм регулювання застосовувався лише до ринку цінних паперів, але згодом був поширений на банківський сектор і сферу страхування. Нова система регулювання передбачала більш ефективну та швидку процедуру прийняття рішень.

3. Право Свропейського Союзу: основні теорії : підручник / Т.М. Анакіна, Т.В. Комарова О.Я. Трагнюк, І.В. Яковюк та ін. Харків : Право, 2019. 360 с.

4. Directive 97/5/EC of the European Parliament and of the Council of 27 January 1997 on cross-border credit transfers. OJ L 43, 14.2.1997, pp. 25-30.

5. Directive 2007/64/EC of the European Parliament and of the Council of 13 November 2007 on payment services in the internal market amending Directives 97/7/EC, 2002/65/EC, 2005/60/EC and 2006/48/EC and repealing Directive 97/5/EC (Text with EEA relevance) /OJ L 319, 5.12.2007, pp. 1-36.

6. Directive (EU) 2015/2366 of the European Parliament and of the Council of 25 November 2015 on payment services in the internal market, amending Directives 2002/65/EC, 2009/110/EC and 2013/36/EU and Regulation (EU) No 1093/2010, and repealing Directive 2007/64/EC.

7. Regulation (EU) No 260/2012 of the European Parliament and of the Council of 14 March 2012 establishing technical and business requirements for credit transfers and direct debits in euro and amending Regulation (EC) No 924/2009.

8. Постанова Правління Національного банку України від 28 грудня 2018 р. № 162. Офіційний вісник України. 2019. № 12 (12.02.2019). Ст. 446.

9. Про Національний банк України : Закон України від 20 травня 1999 р. Відомості Верховної Ради України. 1999. № 29 (23.07.99). Ст. 238.

10. Про банки і банківську діяльність : Закон України від 7 грудня 2000 р. Відомості Верховної Ради України. 2001. № 5-6 (09.02.2001). Ст. 30.

11. Про платіжні системи та переказ коштів в Україні : Закон України від 5 квітня 2001 р. Biдомості Верховної Ради України. 2001. № 29 (20.07.2001). Ст. 137.

12. Про валюту і валютні операції : Закон України від 21 червня 2018 р. Відомості Верховної Ради України. 2018. № 30 (27.07.2018). Ст. 239.

13. Про затвердження Інструкції про порядок відкриття і закриття рахунків кліснтів банків та кореспондентських рахунків банків-резидентів і нерезидентів : Постанова Правління Національного банку України від 12 листопада 2003 р. № 492. Офіиійний вісник України. 2003. № 51 (02.01.2004). Ч. 1. Ст. 2707.

14. Про затвердження Положення про порядок реєстрації платіжних систем, учасників платіжних систем та операторів послуг платіжної інфраструктури : Постанова Правління Національного банку України від 4 лютого 2014 р. № 43. Офіиійний вісник України. 2014. № 23 (25.03.2014). Ст. 718.

15. Про здійснення операцій $з$ використанням електронних платіжних засобів : Постанова Правління Національного банку України від 5 листопада 2014 р. № 705. Офіиійний вісник України. 2014. № 99 (19.12.2014). Ст. 2918.

16. Про міжнародне приватне право : Закон України від 23 червня 2005 р. Відомості Верховної Ради України. 2005. № 32 (12.08.2005). Ст. 422.

17. Про міжнародне приватне право : Закон Австрії 1978 p. URL: https:/www.ris.bka.gv.at/ GeltendeFassung.wxe? Abfrage=Bundesnormen\&Gesetzesnummer=10002426 (дата звернення: 26.11.2019).

18. Про міжнародне приватне право : Закон Швейцарії 1987 p. URL: https://www.admin.ch/opc/de/ classified-compilation/19870312/index.html (дата звернення: 26.11.2019).

19. Інструкція про безготівкові розрахунки в Україні в національній валюті. Офіційний вісник України. 2004. № 13 (16.04.2004). Ст. 908.

20. Типовий закон ЮНСІТРАЛ про міжнародні кредитові перекази 1992 p. URL: https://zakon.rada.gov. ua/laws/show/995_421 (дата звернення: 26.11.2019). 
21. Правове керівництво ЮНСІТРАЛ 3 електронного переведення коштів 1987 p. URL https://zakon.rada.gov.ua/laws/show/995 880 (дата звернення: 26.11.2019).

22. Інкасо - банківські операції, що здійснюються на підставі інструкції клієнтів 3 «фінансовими» (переказні векселі, прості векселі, чеки, платіжні розписки тощо) і «комерційними» документами задля одержання платежів, що їм належать.

23. Уніфіковані правила по інкасо у редакції 1995 p. URL: https://ips.ligazakon.net/document/ MU96447 (дата звернення: 26.11.2019).

24. Довіритель - клієнт, що доручає операцію з інкасування своєму банку.

25. Банк-ремітент - банк, якому довіритель доручає операцію з інкасування.

26. Про внесення змін до деяких нормативно-правових актів Національного банку України : Постанова Правління Національного банку України від 11 квітня 2018 р. № 38. Офіuійний вісник Украӥни. 2003. № 52 (09.01.2004). Ч. 1. Ст. 2831.

27. Уніфіковані правила та звичаї для документарних акредитивів (редакція 1993 р., публікація МТП № 500). Юридичний вісник України. 2008. № 34.

28. Уніфіковані правила та звичаї для документарних акредитивів (редакція 2007 р., публікація МТП № 600). URL: http://search.ligazakon.ua/l_doc2.nsf/link1/FIN32072.html (дата звернення: 26.11.2019).

29. Конвенція ООН про незалежні гарантії та резервні акредитиви від 11 грудня 1995 p. URL: https://zakon.rada.gov.ua/laws/show/995 517\#Text (дата звернення: 26.11.2019).

30. Кодекс торговельного мореплавства України 1995 р. Відомості Верховної Ради Украӥни. 1995. № 47-52 (21.11.95). Ст. 349.

31. Уніфікований закон про переказні векселі та прості векселі 1930 р. Офіиійний вісник Украӥни. 2013. № 31 (29.04.2013). Ст. 1117.

32. Конвенція про врегулювання деяких колізій законів про переказні векселі та прості векселі 1930 р. URL: https://zakon.rada.gov.ua/laws/show/995 007\#Text (дата звернення: 26.11.2019).

33. Конвенція про гербовий збір стосовно переказних та простих векселів 1930 p. URL: https://zakon.rada.gov.ua/laws/show/995 008\#Text (дата звернення: 26.11.2019).

34. Про переказні векселі : Закон Великобританії 1882 p. URL: https://www.legislation.gov.uk/ukpga/ Vict/45-46/61 (дата звернення: 26.11.2019).

35. Про обіг векселів в Україні : Закон України від 5 лютого 2001 р. Відомості Верховної Ради Украӥни. 2001. № 24 (15.06.2001). Ст. 128.

36. Про реформу італійської системи міжнародного приватного права : Закон Iталії 1995 p. URL: https://pravo.hse.ru/intprilaw/doc/040701 (дата звернення: 26.11.2019).

37. Про вексель : Закон КНР від 10 травня 1995 р. URL: https://chinalawinfo.ru/civil_law/law_bill (дата звернення: 26.11.2019).

38. Про регулювання відносин міжнародного приватного права : Закон Румунії 1992 р. № 105. URL: https://pravo.hse.ru/intprilaw/doc/041301 (дата звернення: 26.11.2019).

39. Уніфікований закон про чеки 1931 p. URL: https://zakon.rada.gov.ua/laws/card/995 216 (дата звернення: 26.11.2019).

40. Конвенція, що має на меті вирішення деяких колізій законів про чеки 1931 p. URL: https://zakon.rada.gov.ua/laws/card/995_867 (дата звернення: 26.11.2019).

41. Конвенція про гербовий збір стосовно чеків 1931 p. URL: https://zakon.rada.gov.ua/laws/ card/995_866 (дата звернення: 26.11.2019).

42. Сдиний комерційний кодекс CША. URL: https:/www.law.cornell.edu/ucc/3/3-104 (дата звернення: 26.11.2019).

43. Про цінні папери та фондовий ринок : Закон України від 23 лютого 2006 р. Відомості Верховної Ради України. 2006. № 31 (04.08.2006). Ст. 268.

44. Про затвердження Положення про порядок здійснення операцій з чеками в іноземній валюті на території України : Постанова Правління Національного банку України від 29 грудня 2000 р. № 520. Oфbiųiйний вісник України. 2001. № 8 (09.03.2001). Ст. 329.

45. Про порядок тимчасової дії на території України окремих актів законодавства Союзу РСР : Постанова Верховної Ради України від 12 вересня 1991 р. Відомості Верховної Ради Украӥни. 1991. № 46 (22.11.91). Ст. 621 .

46. Про затвердження положення про чеки : Постанова ЦВК та РНК СРСР від 6 листопада 1929 р. URL: https://zakon.rada.gov.ua/laws/show/n0002400-29\#Text (дата звернення: 26.11.2019). 
УДК 343

DOI https://doi.org/10.32836/2521-6473.2020-4.20

Ш. Б. Давлатов, кандидат юридичних наук, доцент, доцент кафредри правоохоронної діяльності

та кримінально-правових дисциплін

Університету митної справи та фрінансів

А. В. Асєєва,

студентка III курсу Університету митної справи та фрінансів

\section{ПРИМУШУВАННЯ ДО ШЛЮБУ В АСПЕКТІ ПРОТИДІЇ ДОМАШНЬОМУ НАСИЛЬСТВУ: КРИМІНАЛІЗАЦІЯ ТА ІНОЗЕМНИЙ ДОСВІД}

У статті розкрито основні положення статті $151^{2}$, щзо включає примушування особи до вступу в шлюб або до продовження примусово укладеного шлюбу, або до вступу у співжиття без укладання шлюбу, або до продовження такого співжиття, або спонукання задля иього особи до переміщення на територію іншої держави, ніж та, в якій вона проживає. Проаналізовано доцільність криміналізації примушування до шлюбу відповідно до основних принципів та підстав криміналізації. Сформульовано висновок, щьо існування самостійної статті, щзо забороняє вчинення такого діяння, дещо суперечить принципам безпрогальності та не надмірності заборони, а також приведе до виникнення колізій та обтяження Кримінального кодексу України. Проаналізовано основні позиції науковичів з иьього питання та наведено приклади регламентації примушування до шлюбу в кримінальних кодексах таких країн, як Нідерланди, Франція, Норвегія, Чорногорія, Швеиія.

Наведено основні аргументи, щчо зумовлюють такий висновок: на основі головних приниипів та підстав криміналізації, таких як юридико-кримінологічна, соціально-психологічна та соиіально-економічна, сформовано висновок щзодо відповідності криміналізації примушування до шлюбу ичим принциипам та підставам. Проаналізовано досвід іноземних держав в аспекті криміналізації примушування до шлюбу та сформульовано висновок щчодо відмінності у правовому регулюванні изього питання, відповідальності за примушування до шлюбу та формування статті, щчо забороняє вчинення такого діяння.

Встановлено певні статистичні дані щзодо ратифікаиії країнами Європи Стамбульської конвенції, яка регламентує питання домашнього насильства в Європі, а також сформульовано висновок щооо важливості формування офіиійного тлумачення поняття «примушування до шлюбу» задля усунення чи зменшення випадків підміни понять та виникнення колізій. ний аналіз.

Ключові слова: криміналізачія, злочини проти волі, честі та гідності особи, примушування до шлюбу, порівняль-

Sh. B. Davlatov, A. V. Asieieva. Forced marriage in the aspect of combating domestic violence: criminalization and foreign experience

The article reveals the main provisions of article $151^{2}$, which includes forcing a person to enter into marriage or to continue a forced marriage, or to enter into cohabitation without marriage, or to continue such cohabitation, or to induce a person to move to another territory for this purpose state than the one in which she lives.

The article analyzes the feasibility of criminalization of forced marriage in accordance with the basic principles and grounds of criminalization. The conclusion is formulated that the existence of an independent article prohibiting the commission of such an act is somewhat contrary to the principles of dependability but not the excess of the ban, and will also lead to conflicts and encumbrances of the criminal code of Ukraine. The main positions of scientists on this issue are analyzed and examples of the regulation of forced marriage in the criminal codes of countries such as the Netherlands, France, Norway, Montenegro, and Sweden are given.

The purpose and objective of the article is to study the feasibility of criminalizing forced marriage and to make a comparative legal analysis of the laws of Ukraine and Europe. This topic is very relevance and vital because the institution of the family is the main factor that is very important for the development of society.

The main arguments leading to the conclusion are given: on the basis of the basic principles and grounds of criminalization such as legal-criminological, socio-psychological and socio-economic grounds - the conclusion on the compliance of criminalization of coercion to marriage to these principles and grounds. The experience of foreign states in the aspect of criminalization of forced marriage is analyzed and a conclusion is formulated on the differences in the legal regulation of this issue, the responsibility for forced marriage and the formation of an article prohibiting such an act.

Certain statistics have been established regarding the ratification by the European countries of the Istanbul Convention, and governs domestic violence in Europe. It also concluded that it is important to formulate an official interpretation of the concept of "forced marriage" in order to eliminate or reduce cases of substitution of concepts and the occurrence of conflicts.

Key words: crimes against liberty, honor and dignity of person, coercion to marriage, comparative analysis.

(C) Ш. Б. Давлатов, А. В. Ассєва, 2020 
Постановка проблеми. Інститут сім'ї - це основний фактор, який є дуже важливим для розвитку суспільства. Шлюб, відповідно до Цивільного кодексу України, є підставою для створення сім'ї [1]. В Свропі питання насильства у сім'ї регламентує Стамбульська Конвенція (повна назва - Конвенція Ради Європи «Про запобігання та протидію насильству щодо жінок і домашньому насильству та боротьбу із цими явищами») [2], і хоча Україною не ратифіковано цю Конвенцію, проте основним завданням Закону України «Про внесення змін до Кримінального та Кримінального процесуального кодексів України з метою реалізації положень Конвенції Ради Європи про запобігання насильству стосовно жінок і домашньому насильству та боротьбу з цими явищами» від 6 грудня 2017 р. [3] була саме імплементація у чинне кримінальне законодавство положень вищезазначеної Конвенції.

Однак важливим $є$ питання доцільності криміналізації примушування до шлюбу. Серед науковців існують певні розбіжності у думці. Більшість юристів вважає недоцільним введення цієї норми. На нашу думку, що підтверджується наведеними нижче аргументами, криміналізація цього діяння була передчасною.

Аналіз останніх досліджень і публікацій. Щодо недоцільності криміналізації цього діяння висловлювали свою думку такі вчені, як О.М. Литвинов, Ю.Б. Данильченко. Однак більшість учених все ж таки проти такої новели, зокрема С.Ф. Денисов, О.О. Круглова, В.В. Шаблистий, Е.М. Кисілюк. Хоча достатньо вчених приділили увагу цьому питанню, все одно воно $є$ дуже актуальним та потребує всебічного аналізу.

Мета статті полягає у дослідженні доцільності криміналізації примушування до шлюбу, проведенні порівняльно-правового аналізу законодавства України та Європи.

Виклад основного матеріалу. Статтею $151^{2}$ Кримінального кодексу України (далі - КК України) встановлена відповідальність за такий злочин, як примушування до шлюбу, тобто за примушування особи до вступу в шлюб або до продовження примусово укладеного шлюбу, або до вступу у співжиття без укладання шлюбу, або до продовження такого співжиття, або спонукання задля цього особи до переміщення на територію іншої держави, ніж та, в якій вона проживає, особа буде нести відповідальність у вигляді арешту на строк до шести місяців або обмеження волі на строк до трьох років, або позбавлення волі на той самий строк.

Окремо регламентовано питання щодо можливості вчинення такого діяння, як примушування до шлюбу малолітньої дитини, тобто примушування до шлюбу особи, яка не досягла шлюбного віку. Зокрема, якщо злочин вчинено щодо особи віком до 14 років, а шлюбний вік згідно із законодавством України дорівнює 18 , то діяння треба кваліфікувати за частиною 2 статті 151-2 КК [4].

Основним безпосереднім об’єктом злочину є воля, честь і гідність особи, зокрема у сімейних відносинах.

Відповідно до статті 24 Сімейного кодексу України (далі - СКУ), шлюб грунтується на вільній згоді жінки та чоловіка; примушування жінки та чоловіка до шлюбу не допускається, за статтею 56 СКУ, кожен 3 подружжя має право припинити шлюбні відносини; примушування до припинення шлюбних відносин, примушування до їх збереження, зокрема примушування до статевого зв'язку за допомогою фізичного або психічного насильства, $є$ порушенням права дружини, чоловіка на свободу та особисту недоторканність і може мати наслідки, встановлені законом [5].

Потерпілою від злочину може бути будь-яка особа незалежно від статі і віку. Примушування особи до вступу в шлюб або до продовження примусово укладеного шлюбу, або до вступу у співжиття без укладання шлюбу, або до продовження такого співжиття, або спонукання задля цього особи до переміщення на територію іншої держави, ніж та, в якій вона проживає, караються арештом на строк до шести місяців або обмеженням волі на строк до трьох років, або позбавленням волі на той самий строк.

M.І. Хавронюк дає авторське тлумачення цієї статті: «примушування означає застосування фізичного насильства або погрозу його застосування щодо потерпілого чи його близької особи, або шантаж - погрозу знищити чи пошкодити майно потерпілого, або викрасти потерпілого чи позбавити його волі, або розголосити відомості про потерпілого, які потерпілий бажає зберегти у таємниці, або іншим чином обмежити права, свободи чи законні інтереси потерпілого (чи його близької особи)» [6, с. 455]. Однак вважаємо за доцільне зауважити, що таке тлумачення $є$ не офіційним, а авторським, що прямо не випливає з тексту, встановленому КК України.

Криміналізація примушування до шлюбу не була обумовлена ратифікацією Стамбульської Конвенції у порядку, визначеному частиною 7 статті 9 Закону України «Про міжнародні договори України». Для того щоби виконати поставлені завдання, нам необхідно зрозуміти, якими були підстави криміналізації примушування до шлюбу, тобто ті фактори, які зумовлюють існування цього діяння, як самостійної статті.

Для початку необхідно зрозуміти, що розуміється під поняттям «криміналізація». Вважаємо обгрунтованим визначення, яке надає П.Л. Фріс: криміналізація - це процес виявлення суспільно небезпечних видів людської поведінки, визнання на державному рівні необхідності, можливості й доцільності кримінально-правової боротьби з ними та закріплення їх у законі про кримінальну відповідальність як злочинів $[7$, c. 2].

О.І. Коробоєв [8] виділяє такі цікаві, на наш погляд, підстави криміналізації.

1. Юридико-кримінологічна, що полягає в тому, що криміналізація доречна тільки тоді, коли є реальна 
суспільна небезпечність і той фактор, що іншим способом неможливо врегулювати ці відносини, окрім як криміналізувати їх. Щодо цього ми вважаємо таке. У висновку Головного науково-експертного управління на проєкт Закону України «Про внесення змін до деяких законів України у зв’язку з ратифікацією Конвенції Ради Європи про запобігання насильству стосовно жінок і домашньому насильству та боротьбу 3 цими явищами» зазначалось, що саме по собі примушування особи до шлюбу без настання суспільно небезпечних наслідків не досягає того рівня суспільної небезпеки, коли діяння має визнаватися злочином відповідно до статті 11 КК України [9].

Однак у цьому разі, хоч це й підтверджує нашу позицію щодо недоцільності криміналізації примушування до шлюбу, ми не погоджуємося з вищезазначеною думкою. Слушним аргументом, на наш погляд, $\epsilon$ таке висловлення О.В. Харитонової: «примусовий шлюб порушує право людини вільно вирішувати, чи брати шлюб, коли це робити і $з$ ким» [10, с. 65]. Ми вважаємо, що суспільна небезпечність цього діяння полягає у посяганні на свободу людини, а, як відомо, за Конституцією України, свобода людини - це найвища цінність. Хоча ми визнаємо небезпечність примушування до шлюбу, ми вважаємо, що за наявності певних обставин винного можна притягнути до відповідальності за такими статтями, як стаття 129 ККУ «Погроза вбивством», стаття 146 ККУ «Незаконне позбавлення волі або викрадення людини», стаття 154 ККУ «Примушування до вступу в статевий зв’ язок», стаття 149 ККУ «Торгівля людьми або інша незаконна угода щодо людини» $[11$, с. 34$]$.

Отже, щодо примушування до шлюбу, вважаємо, що юридико-кримінологічна підстава відсутня.

2. Соціально-економічна, що полягає у врахуванні можливих позитивних і негативних наслідків криміналізації.

На нашу думку, позитивним моментом є відчуття захищеності в осіб, які страждають від таких діянь, як примушування до шлюбу, а щодо негативних, то ми можемо припустити порушення двох таких альтернативних принципів криміналізації:

- принцип економії кримінальної репресії, адже з огляду на неточність норми та можливість підміни понять до відповідальності може бути притягнуто невиправдано велике число громадян;

- принцип невідворотності відповідальності, оскільки з тієї ж самої причини на практиці через незрозумілість та використання інших статей норма перестає застосовуватися.

3. Соціально-психологічна, що полягає у врахуванні правового менталітету. Ця підстава є однією з найскладніших під час застосування.

Щодо важливості вільного волевиявлення під час реєстрації шлюбу зазначається у Конституції України (частина 1 статті 51), у СКУ (частина 1 статті 24). У частині 1 статті 40 СКУ зазначено, що шлюб визнається недійсним за рішенням суду, якщо він був зареєстрований без вільної згоди жінки або чоловіка. Згода особи не вважається вільною, зокрема, тоді, коли в момент реєстрації шлюбу вона страждала тяжким психічним розладом, перебувала у стані алкогольного, наркотичного, токсичного сп'яніння, в результаті чого не усвідомлювала сповна значення своїх дій і (або) не могла керувати ними, або якщо шлюб було зареєстровано в результаті фізичного чи психічного насильства [5].

Якщо брати примушування до шлюбу як окрему статтю, то це імплементація статті 37 Стамбульської Конвенції, у якій, на думку О.В. Харитонова, вона є необхідною з огляду на те, що чимало жертв примусових шлюбів доставляють до іншої країни (часто це країни походження їх або їхніх предків) і примушують укласти шлюб чи вступити у співжиття з особою з цієї країни [10, с. 65].

Отже, на нашу думку, криміналізація примушування до шлюбу є недоцільною, це порушує основні підстави та принципи криміналізації, які зазначені вище, а також обтяжує кримінальний кодекс та може слугувати причиною певних колізій.

Окремої уваги заслуговує досвід європейських держав. Як уже зазначалося, не всі держави ратифікували Стамбульську Конвенцію, але все ж таки у більшості європейських держав існує кримінальна відповідальність за такий злочин, як примушування до шлюбу.

Варто зазначити, що такі країни, як Латвія, Литва, Словаччина, Чехія, Греція, Люксембург, Угорщина, Болгарія, Ірландія, Велика Британія, також не ратифікували вищезазначену Конвенцію [12].

Щодо того, як регулюється це питання у різних країнах, які ратифікували Конвенцію, наведемо такі приклади.

1. У Нідерландах статтею 284 встановлена відповідальність за примушування до шлюбу: «будь-яка особа, яка: 1) незаконно змушує іншу особу діяти або утримуватися від певних дій або терпіти певні дії через акт насильства чи будь-якого іншого діяння або загрози насильства, або загрози будь-яким іншим діянням, спрямованим проти цього іншого або проти інших осіб; 2) змушує іншу особу діяти або утримуватися від певних дій або терпіти певні дії через загрозу обмовляння або наклепу; карається позбавленням волі, яке не перевищує дев'яти місяців, або штрафом третьої категорії (до 8200 євро)» [13].

2. У Франції визначається кримінально караним «факт примушування особи укласти шлюб або укладення шлюбу за кордоном шляхом введення особи в оману задля підбурювання ії до виїзду з території Республіки, що карається трьома роками позбавлення волі та штрафом у розмірі 45000 євро (стаття 222-14-4)» [14]. 
3. У Норвегії статтею 253 встановлюється відповідальність за примушування до шлюбу до 6 років ув'язнення. Таке ж саме покарання встановлюється за допомогу чи підтримку у вчиненні такого діяння [15].

4. У Чорногорії існує досить цікава ситуація, коли відповідальність встановлюється не тільки за примушування до шлюбу, але й за обман під час укладення шлюбу: «кожний, хто укладає шлюб, приховуючи від іншої сторони факт, що робить шлюб недійсним, або хто обманює чи вводить іншу сторону в оману щодо цього факту, карається позбавленням волі від трьох місяців до трьох років. Той, хто примушує або погрожує іншій особі укласти шлюб, карається позбавленням волі на строк від шести місяців до п'яти років», що встановлено статтею 214 [16].

5. Секцією 4c Кримінального кодексу Швеції встановлено покарання за примушування до шлюбу у вигляді ув’язнення «на будь-який строк до 4 років» [17].

В Україні ж санкція статті $151^{2}$ встановлює «арешт на строк до шести місяців або обмеження волі на строк до трьох років, або позбавлення волі на той самий строк» [4].

Якщо порівнювати це питання в аспекті правового регулювання, то можемо побачити, що в більшості європейських країнах санкція є більш жорсткою. Однак вважаємо доцільним зауважити, що у більшості країн тлумачення діянь, що розуміються під примушуванням до шлюбу, є більш повним та конкретизованим, а в деяких країнах доповнюється такими діяннями, як допомога й підтримка у примушуванні до шлюбу.

Висновки $з$ дослідження і перспективи подальших розвідок у цьому напрямі. За даними Всесвітньої організації охорони здоров’я, у 2014 році кожна шоста жінка зазнала насильства в сім’ї. Відповідно до цих же даних, ця проблема є більш гострою для економічно слабо розвинених країн, при цьому жінки в цих країнах з більшою вірогідністю визнають таке насильство над собою виправданим. Така статистика не є втішною, тому у більшості європейських країн відбулася ратифікація Стамбульської Конвенції, а також запровадження інституту кримінальної відповідальності за примушування до шлюбу.

Порівнюючи правову регламентацію цього питання в іноземних державах та в Україні, ми дійшли висновку, що за умови конкретизації, деталізації та наповнення кваліфікуючими ознаками статті $151^{2}$ iснує необхідність у цій статті, а на цьому етапі це «мертва норма», яку можна замінити іншими нормами, що наводилися вище.

Отже, результатом існування цієї статті можуть стати труднощі у застосуванні їі на практиці, тлумаченні та притягненні до відповідальності.

Відсутність законодавчо встановленої дефініції поняття «примушування до шлюбу» може призвести до підміни понять та широкого трактування правозастосовними органами на практиці.

Підсумовуючи, зазначимо, що криміналізація примушування до шлюбу в Україні є недоцільною та призведе до обтяження КК України та складності застосування норми на практиці, тому вважаємо, що необхідно ставити питання про тлумачення та розкриття поняття «примушування до шлюбу», що відмежувало б цей злочин від суміжних діянь, чи декриміналізацію цього діяння.

\section{Список використаних джерел:}

1. Цивільний кодекс України : Закон України від 16 січня 2003 р. № 435-IV. Відомості Верховної Ради України. 2003. № № 40-44. Ст. 356. URL: http://zakon2.rada.gov.ua/laws/show/435-15/conv/page (дата звернення: 02.06.2020).

2. Конвенція Ради Європи про запобігання насильству стосовно жінок і домашньому насильству та боротьбу з цими явищами та пояснювальна доповідь. Стамбул (Туреччина). 11.V.2011 p. / Council of Europe. URL: https://rm.coe.int/ 1680093d9e (дата звернення: 02.06.2020).

3. Про внесення змін до Кримінального та Кримінального процесуального кодексів України 3 метою реалізації положень Конвенції Ради Європи про запобігання насильству стосовно жінок і домашньому насильству та боротьбу з цими явищами : Закон України від 6 грудня 2017 р. № 2227-VIII // Законодавство України. URL: http://zakon.rada.gov.ua/laws/show/2227-19 (дата звернення: 02.06.2020).

4. Кримінальний кодекс України : Закон України від 5 квітня 2001 р. № 2341-III. Відомості Верховної Ради України. 2001. № 25-26. С. 131.

5. Сімейний кодекс України : Закон України від 10 січня 2002 р. № 2947-III. Відомості Верховної Ради України. 2002. № 21-22. Ст. 135.

6. Науково-практичний коментар Кримінального кодексу України / за ред. М.I. Мельника, M.I. Хавронюка. 10-те вид., переробл. та доп. Київ : ВД «Дакор», 2018. 1360 с.

7. Фріс П.Л. Криміналізація і декриміналізація у кримінально-правовій політиці. Вісник Асоиіаціï кримінального права України. 2014. № 1 (2). C. 10. URL: http://nauka.nlu.edu.ua/wp-content/uploads/2015/ 07/2_2.pdf (дата звернення: 02.06.2020).

8. Коробеев А.И. Советская уголовная политика: понятие, содержание, структура. Владивосток : изд-во ДВГУ, 1985.

9. Висновок на проєкт Закону України «Про внесення змін до деяких законів України у зв'язку з ратифікацією Конвенції Ради Свропи про запобігання насильству стосовно жінок і домашньому насильству та 
боротьбу з цими явищами» від 14 листопада 2016 р. / Верховна Рада України. URL: https://ips.ligazakon.net/ document/view/xh3tk00a?an=17\&ed=2016_11_14 (дата звернення: 03.06.2020).

10. Харитонова О.В. Ключові засади гендерної політики в кримінальному праві України та основні напрями реформ щодо протидії насильству стосовно жінок та домашньому насильству : науково-практичний посібник. Харків : Права людини, 2018. 344 с.

11. Кісілюк Е.М. Особливості гармонізації та врегулювання термінології щодо гендерно зумовленого насильства в рамках внесення змін до Кримінального кодексу України. Актуальні проблеми кримінального права, кримінології та кримінально-виконавчого права : матеріали Всеукраїнської науково-практичної конференції (25 травня 2018 р., м. Дніпро). Дніпро : Дніпропетровський державний університет внутрішніх справ, 2018. С. 32-34.

12. В Свропарламенті закликали 10 країн ЕС ратифікувати Стамбульську конвенцію. Свропейська правда. 2018. 13 червня. URL: https://www.eurointegration.com.ua/news/2018/06/13/7083076 (дата звернення: 03.06.2020).

13. Кримінальний кодекс Нідерландів - стаття 284. URL: http://aw.edu.ru/norm/norm.asp?normID=1242 430\&subID=100100457,100100459\#text (дата звернення: 04.06.2020).

14. Кримінальний кодекс Франції-стаття 222-14-4.URL:https://www.legifrance.gouv.fr/affichCodeArticle. do?idArticle=LEGIARTI 000027809362\&cidTexte=LEGITEXT000006070719 (дата звернення: 04.06.2020).

15. Кримінальний кодекс Норвегії - стаття 253. URL: https://www.legislationline.org/download/id/8657/ file/Norway_Penal_Code_2015_am2020_en.pdf (дата звернення: 04.06.2020).

16. Кримінальний кодекс Чорногорії. URL: http://www.mpa.gov.me/biblioteka/zakoni?alphabet=cyr (дата звернення: 04.06.2020).

17. Кримінальний кодекс Швеції, секція 4c. URL: https://www.legislationline.org/download/id/8662/file/ Sweden_criminal_code_am2020_en.pdf (дата звернення: 04.06.2020). 